\title{
Volver a entrar saltando: \\ Memorias visuales de la segunda generación de exiliados políticos en México
}

\section{Prof. María Florencia Basso}

Tesis para optar por el grado de Magíster en Historia y Memoria

Directora Dra. Leticia Muñoz Cobeñas, Universidad Nacional de La Plata Codirector Dr. Daniel Lvovich, Universidad Nacional de General Sarmiento/ Universidad Nacional de La Plata/CONICET 


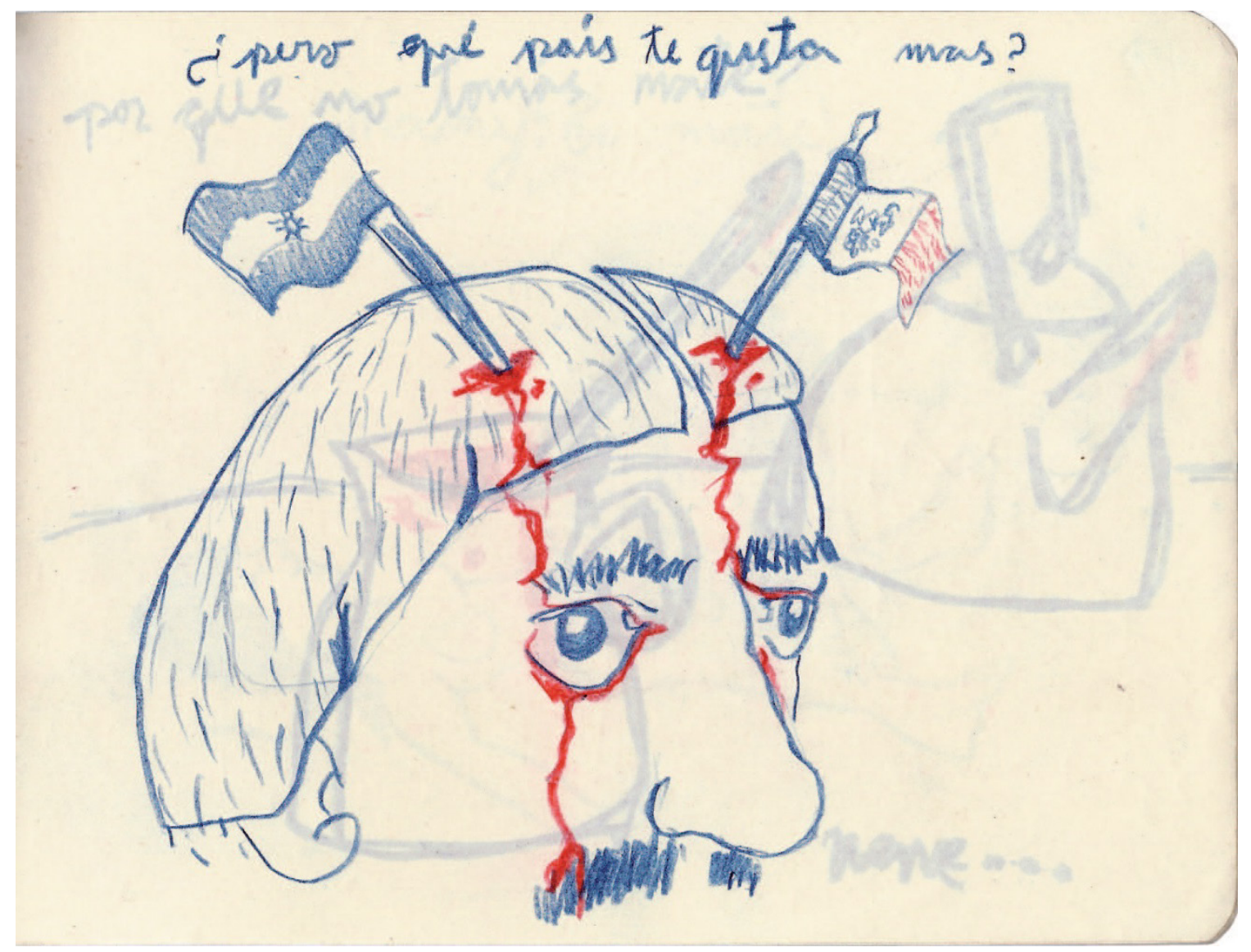

Imagen extraída de la serie de dibujos Un niño de 30 años (2006) de Tomás Alzogaray. 
A mis viejos y Ger

A Santi 


\section{RESUMEN}

Tras la violencia desplegada por el terrorismo de estado en Argentina durante el tercer peronismo y, especialmente, después del golpe militar de marzo de 1976 y la instauración de la dictadura cívico-militar argentina (1976-1983); muchos argentinos se vieron forzados por razones políticas a abandonar el país. El exilio formó parte de las violaciones a los derechos humanos ejercidas por el poder estatal y paraestatal, como la persecución, detención, tortura sistematizada, apropiación de niños y desaparición forzada de personas. México fue uno de los principales países receptores de estas familias exiliadas donde los hijos debieron lidiar entre las dos culturas. En esta tesis nos centramos en las relaciones entre arte, memoria y exilio a partir de un conjunto de producciones visuales actuales (2001 en adelante) de artistas pertenecientes a la segunda generación de exiliados políticos en México -hijos nacidos y/o criados en México de padres argentinos exiliados- y que han retornado a la Argentina. Nuestro objetivo principal es indagar sobre las múltiples memorias que se cruzan en la construcción identitaria argenmex a partir de un corpus de producciones artísticas en torno al pasado reciente argentino, teniendo en cuenta la especificidad del medio artístico -ya sea fotográfico, corporal u objetual. En este sentido, apuntamos, desde el análisis de estas memorias privadas/familiares expuestas en espacios públicos, a indagar sobre la construcción colectiva de los procesos identitarios de la Argentina reciente.

Nuestra principal hipótesis, que articula los diversos núcleos temáticos, sostiene que las especificidades artísticas de cada uno de los medios puestos en juego, es decir lo fotográfico, lo corporal y lo objetual, son espacios privilegiados para la elaboración y transmisión de memorias traumáticas, del exilio, del retorno, entre otras. Nos preguntamos, en este sentido, cuál es el aporte del arte a la memoria. Nuestro corpus se centra en la producción de la segunda generación de exiliados en México, lo cual implica tener en cuenta las siguientes líneas en la investigación: el proceso de formación, institucionalización (JAE, H.I.J.O.S., Hijas e Hijos del Exilio) y prácticas de la segunda generación (producciones cinematográficas, literatura, grafitis, eventos culturales, etc.), los roles de los hijos en el exilio y en el interior de la familia exiliada, así como las especificidades de aquellos hijos que se exiliaron en México y que, por lo tanto, comparten marcas culturales únicas condensadas en la construcción identitaria argenmex. Asimismo abordamos las características de las propias memorias de los hijos 
conformadas en un núcleo familiar atravesado por el trauma colectivo, para lo cual revemos la noción de posmemoria junto con sus debates y polémicas. Recuperando estas líneas, nuestra investigación reflexiona sobre las contribuciones de la segunda generación que, desde el arte y el exilio en México, apuestan a la reciente tradición fraguada en el cruce entre arte y memoria. Nos preguntamos, entonces, cuales son los "trabajos" de las memorias (acting out, elaboración, duelo, melancolía, ritual, entre otros) de esta generación exiliada en México y retornada a la Argentina.

La tesis se estructura en dos partes. En la primera abordamos las particularidades del exiliado político en México, entre ellas, la construcción identitaria argenmex; las problemáticas específicas de la segunda generación de exiliados; la relación entre la memoria y las prácticas poético-testimoniales y el lugar que ocupan estas prácticas en la historia del arte y la construcción colectiva del pasado. En esta instancia, conformada por los capítulos uno y dos, intentamos generar herramientas teóricas que nos ayuden a analizar y problematizar en profundidad las producciones artísticas planteadas en la segunda parte de la tesis. En los capítulos tres, cuatro y cinco, agrupamos, entonces, las diferentes producciones artísticas a través del tipo de medio -teniendo en cuenta que en la mayoría de las obras se conforman desde lo multidisciplinario-: lo fotográfico en el capítulo tres, con Fotos lavadas (2005-2010) de Soledad Sánchez Goldar y Fotos Tuyas (2001-2002) de Inés Ulanovsky; lo corporal en el capítulo cuatro, con Tres Bellas Heridas (2007) de Soledad Sánchez Goldar y la trayectoria de Magdalena Jitrik y su paso por el Taller Popular de Serigrafía (2002-2007); y lo objetual en el capítulo cinco, con Árbol del desexilio (2006-2010) y 7Historias (2008) de Mercedes Fidanza, Un niño de 30 años (2006) y El niño que odia (2007-2011) de Tomás Alzogaray, y El Objeto del Exilio (2013) de Liza Casullo y Federico Joselevich Puiggrós.

\section{PALABRAS CLAVES}

ARTE - MEMORIA - EXILIO - HIJOS - ARGENMEX 


\section{INDICE}

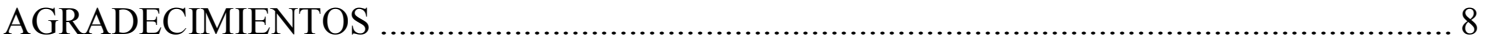

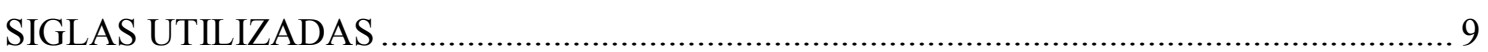

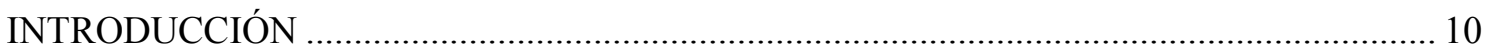

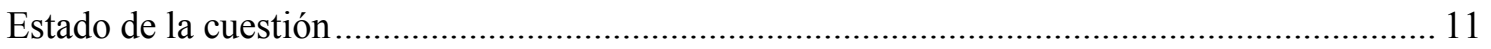

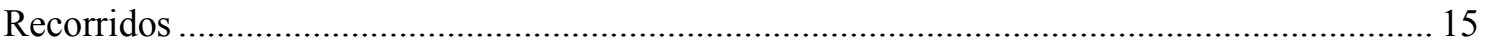

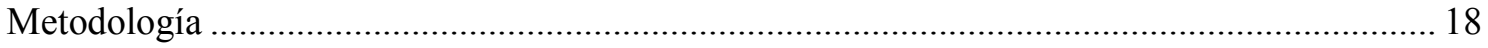

CAPÍTULO 1. EXILIO POLÍTICO EN MÉXICO Y SEGUNDA GENERACIÓN DE ARGENMEX

En torno a la especificidad del exilio político argentino en México .............................................. 22

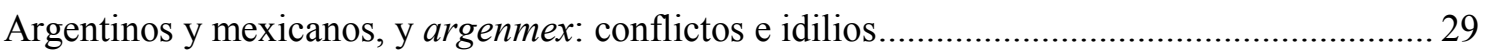

“¿Y a mí qué me importa?” o "El que se enoja, pierde” ..................................................... 33

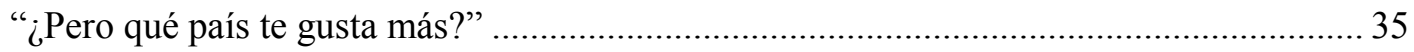

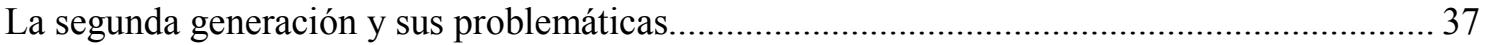

CAPÍTULO 2. MEMORIA, TESTIMONIO, ¿POS?MEMORIA Y ARTE ................................... 43

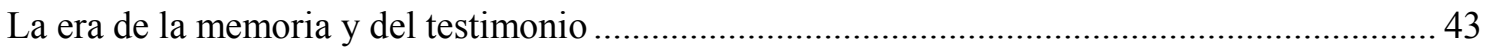

Las víctimas: los supervivientes y los alertadores de incendios ......................................... 45

Las prácticas poéticas-testimoniales de la segunda generación .......................................... 49

Testimonio: ¿verdad o ficción o verdad/ficción? ................................................................... 55

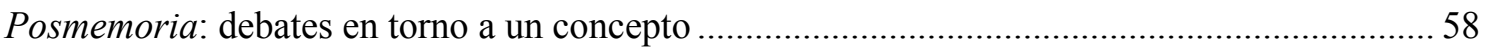

Memoria e Historia del Arte: en torno a las producciones artísticas de la segunda generación . 67

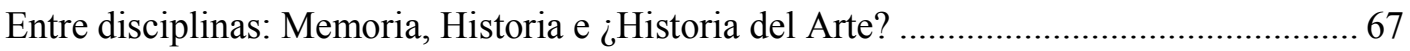

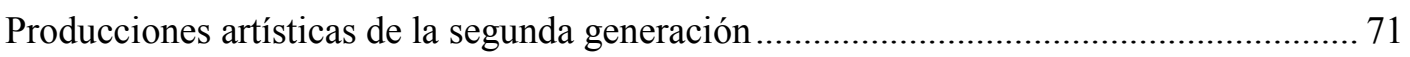

CAPÍTULO 3. LO FOTOGRÁFICO Y LA MEMORIA …......................................................... 74

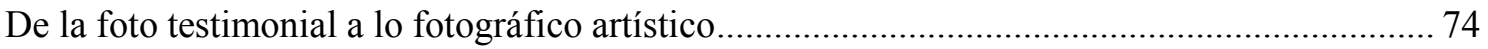

De la foto íntima y familiar a la foto pública: Fotos lavadas de Soledad Sánchez Goldar.......... 79

De la foto talismán a la foto artística: Fotos tuyas de Inés Ulanovsky ........................................ 86

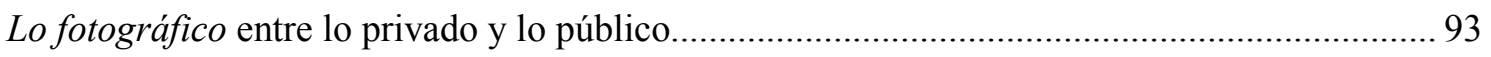

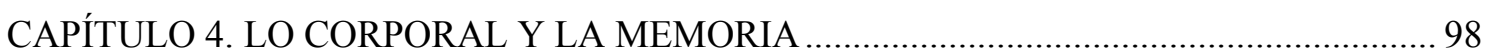

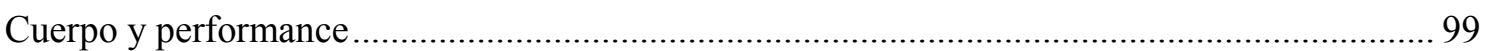

Memorias traumáticas a través del cuerpo y performance …................................................... 101

El cuerpo del desparecido en acciones artísticas: antecedentes ................................................ 105

El cuerpo en el activismo artístico del TPS y el cuerpo familiar en Tres Bellas Heridas ......... 108

Los hijos en México entre la militancia y el arte: Magdalena Jitrik y la JAE.................... 109

De la Comisión de Escrache en H.I.J.O.S. a la Mesa de Escrache Popular ....................... 111 
2001 y el nuevo ciclo de movilización social: los colectivos artísticos

Activismo artístico en la Mesa de Escrache Popular: la participación del TPS

Cuerpo íntimo y familiar en Tres Bellas Heridas de Soledad Sánchez Goldar 123

CAPÍTULO 5. LO OBJETUAL Y LA MEMORIA .................................................................. 132

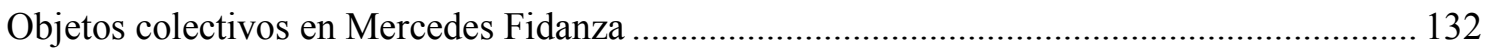

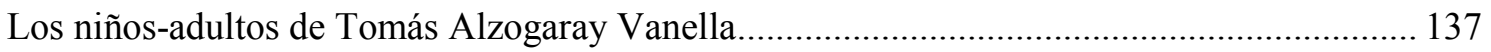

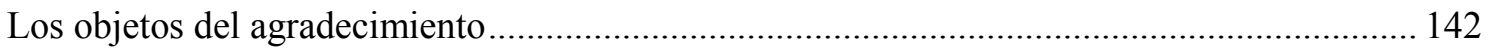

Las múltiples memorias de lo objetual artístico en los hijos exiliados ..................................... 143

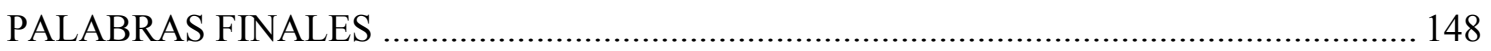

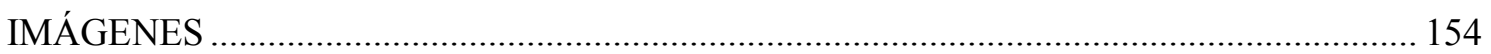

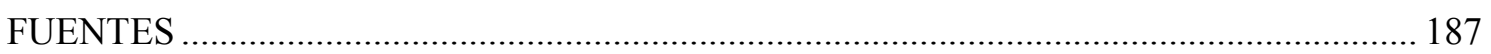

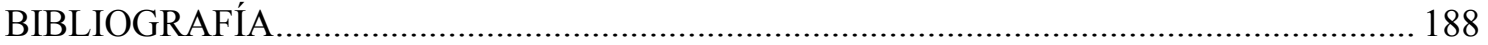




\section{AGRADECIMIENTOS}

Está investigación no hubiera sido posible realizarla sin el sostén de muchas personas e instituciones. Quiero dar mi más sincero agradecimiento a mis directores, Leticia Muñoz Cobeñas y Daniel Lvovich por su dedicado y constante acompañamiento en cada una de las etapas de esta tesis. El apoyo de Leticia excede ampliamente estos años de investigación, dado que ya desde mi bachillerato en Bellas Artes siempre me impulsó a generar más preguntas que respuestas y a construir el pensamiento desde lo afectivo y lo político. La comprometida y atenta lectura de Daniel de cada uno de los capítulos me ayudó a comprender las complejidades de los temas específicos de cada disciplina. Agradezco muy especialmente a Lelé De Rueda, quien me impulsó en el mundo de la investigación y me acompañó desde el primer momento en el transcurso de las becas de la UNLP.

Esta tesis fue posible por el apoyo de las becas de investigación de la Universidad Nacional de La Plata y la beca PROFOR del Ministerio de Educación y Deportes de la Nación. Agradezco a los profesores y administrativos de la Facultad de Bellas Artes por darme un espacio de formación y trabajo en torno a la historia del arte. A la Maestría en Historia y Memoria y sus profesores, a Aletheia, a Andrés Bisso, Ana Barletta, Soledad Lastra y Florencia Larralde Armas y al cálido apoyo de Laura Lenci. A todos los que me acompañaron en México durante mi estadía. Muy especialmente a los artistas y entrevistados, Soledad Sánchez Goldar, Mercedes Fidanza, Tomás Alzogaray, Inés Ulanovsky, Magdalena Jitrik y Federico Joselevich Puiggrós.

Como sabemos, sólo se logra una tesis con la complicidad cotidiana de los amigos y la familia. Gracias a mis amigos del alma Leti -y compinche en Puchero-, Marian, Rotur, Fran, Nati, Agus, Caro y todo el grupo bachi. Por toda la escucha atenta e intercambios en los viajes a capital, a Mari. A las chicas en las Almendras. Gracias a mis compañeros de maestría que son, ahora, amigos de la vida: Andre, amiga incansable de estudio y charlas; a Vane; Lu; Elías; Jime, y Bren. A mi mamá que, además de madre, es una excelente profesional en letras y me enseñó el oficio de la escritura, gracias ma! A mi papá y mi hermano que están siempre. Gracias a Ro y Fran por todos los asados. Y gracias al compañero de proyectos, momentos, viajes, risas y aprendizajes, Santiago Prieto. 


\section{SIGLAS UTILIZADAS}

ACNUR: Alto Comisionado de las Naciones Unidas para los Refugiados

AIDA: Asociación Internacional de Defensa de los Artistas

CABA: Ciudad Autónoma de Buenos Aires

CAPataco: Colectivo de Arte Participativo tarifa común

CAS: Comisión Argentina de Solidaridad

CCB: Centro Cultural Borges

CCEC: Centro Cultural España Córdoba

CePIA: Centro de Producción e Investigación en Artes

COEPRA: Comisión de Ex Exiliados Políticos de la República Argentina

COMAR: Comisión Mexicana de Ayuda a los Refugiados

COSPA: Comité de Solidaridad con el Pueblo Argentino

DF: Distrito Federal

ExESMA: Ex Escuela Mecánica de la Armada

ERP: Ejército Revolucionario del Pueblo

GAC: Grupo de Arte Callejero

GAS-TAR: Grupo de Artistas Socialistas - Taller de Arte Revolucionario

H.I.J.O.S.: Hijos e Hijas por la Identidad y la Justicia contra el Olvido y el Silencio IUNA: Instituto Universitario Nacional del Arte

JAE: Juventud Argentina en el Exilio

PRT: Partido Revolucionario de los trabajadores

TPS: Taller Popular de Serigrafía

UBA: Universidad de Buenos Aires

UNC: Universidad Nacional de Córdoba

UNLP: Universidad Nacional de La Plata

UNSAM: Universidad Nacional de San Martín 


\section{INTRODUCCIÓN}

A lo largo de las diversas etapas educativas -inicial, primaria, secundaria y superior- estamos acostumbrados a relacionarnos teóricamente con lo artístico dentro del mundo limitado y reglado de la "gran" Historia del Arte. El análisis formal, las cronologías, los estudios de los estilos, las disciplinas artísticas son, de algún modo, encapsulados por esta mirada. Sin embargo, en el interior de ciertos espacios académicos -un poco más reducidos- hay una continua puja por querer insertar otras maneras de ver y reflexionar acerca de las imágenes -con otras historias, otros protagonistas, otras metodologías. En esta tesis intentamos aportar algo en ese recorrido. Ubicamos, en un primer lugar, a la memoria como anteojo epistemológico. A partir, entonces, de las producciones artísticas y de los estudios de memoria, reflexionamos en el presente- tanto sobre la elaboración del pasado como la construcción del futuro.

Tras la violencia desplegada por el terrorismo de estado en Argentina durante el tercer peronismo y, especialmente, después del golpe militar de marzo de 1976 y la instauración de la dictadura cívico-militar argentina (1976-1983); muchos argentinos se vieron forzados por razones políticas a abandonar el país. El exilio formó parte de las violaciones a los derechos humanos ejercidas por el poder estatal y paraestatal, como la persecución, detención, tortura sistematizada, apropiación de niños y desaparición forzada de personas. México fue uno de los principales países receptores de estas familias exiliadas donde los hijos debieron lidiar entre las dos culturas. En esta tesis nos centramos en las relaciones entre arte, memoria y exilio a partir de un conjunto de producciones visuales actuales (2001 en adelante) de artistas pertenecientes a la segunda generación de exiliados políticos en México -hijos nacidos y/o criados en México de padres argentinos exiliados- y que han retornado a la Argentina ${ }^{1}$. Nuestro objetivo principal es indagar sobre las múltiples memorias que se cruzan en la construcción identitaria argenmex a partir de un corpus de producciones artísticas en torno al pasado reciente argentino, teniendo en cuenta la especificidad del medio artístico -ya sea fotográfico, corporal u objetual. En este sentido, apuntamos, desde el análisis de estas

\footnotetext{
${ }^{1}$ Los padres de los artistas elegidos en la presente tesis han sufrido violaciones a los derechos humanos de distinto tipo, como persecución, detención, tortura, y exilio. En ningún caso de los abordados en la presente tesis, el padre o la madre se encuentran desaparecidos, pero si muchos de ellos tienen algún tío/tía o familiar cercano desaparecido.
} 
memorias privadas/familiares expuestas en espacios públicos, a indagar sobre la construcción colectiva de los procesos identitarios de la Argentina reciente.

Nuestra principal hipótesis, que articula los diversos núcleos temáticos, sostiene que las especificidades artísticas de cada uno de los medios puestos en juego, es decir lo fotográfico, lo corporal y lo objetual, son espacios privilegiados para la elaboración y transmisión de memorias traumáticas, del exilio, del retorno, entre otras. Nos preguntamos, en este sentido, cuál es el aporte del arte a la memoria. Nuestro corpus se centra en la producción de la segunda generación de exiliados en México, lo cual implica tener en cuenta las siguientes líneas en la investigación: el proceso de formación, institucionalización (JAE, H.I.J.O.S., Hijas e Hijos del Exilio) y prácticas de la segunda generación (producciones cinematográficas, literatura, grafitis, eventos culturales, etc.), los roles de los hijos en el exilio y en el interior de la familia exiliada, así como las especificidades de aquellos hijos que se exiliaron en México y que, por lo tanto, comparten marcas culturales únicas condensadas en la construcción identitaria argenmex. Asimismo abordamos las características de las propias memorias de los hijos conformadas en un núcleo familiar atravesado por el trauma colectivo, para lo cual revemos la noción de posmemoria junto con sus debates y polémicas ${ }^{2}$. Recuperando estas líneas, nuestra investigación reflexiona sobre las contribuciones de la segunda generación que, desde el arte y el exilio en México, apuestan a la reciente tradición fraguada en el cruce entre arte y memoria. Nos preguntamos, entonces, cuales son los "trabajos" de las memorias (acting out, elaboración, duelo, melancolía, ritual, entre otros) de esta generación exiliada en México y retornada a la Argentina.

\section{Estado de la cuestión}

Dos grandes ejes temáticos atraviesan continuamente las producciones visuales de los artistas seleccionados: las memorias propias de la segunda generación -o (pos)memorias- y el exilio político a México y su construcción identitaria argenmex. Haremos un breve recorrido por el estado de la cuestión con respecto a estos dos núcleos.

\footnotetext{
${ }^{2}$ En esta tesis nos centramos en las formas artísticas de elaboración de las memorias traumáticas. Las reflexiones, entonces, están dirigidas al núcleo de artistas exiliados de la segunda generación y a la instancia de producción de sus obras. Sería sumamente interesante analizar la circulación y recepción de las mismas. Si bien abordamos algunas cuestiones en relación a esto, para un análisis en profundidad habría que realizar un trabajo de estudio de campo, investigación y reflexión que excede la presente tesis.
} 
Por un lado, en el contexto de la llamada era de la memoria ${ }^{3}$, se desarrolla la noción de posmemoria para abarcar las memorias de los hijos de aquellos que han sido víctimas de los genocidios políticos del siglo XX. El término fue acuñado a finales de 1980, principalmente en producciones culturales de Estados Unidos y Europa, para analizar el caso de la generación posterior a la de los sobrevivientes de la Shoah (se destacan los trabajos de Marianne Hirsch y James Young). También fue repensado para trabajar sobre la generación de hijos de las dictaduras de estado del Cono Sur. Mónica Szurmuk (2009) menciona las principales problemáticas y traza un panorama de los estudios y las producciones culturales en relación a la posmemoria tanto en Europa y Estados Unidos, como en Latinoamérica. En Argentina, la especificidad de este término es cuestionado por Beatriz Sarlo en su libro Tiempo Pasado, cultura de la memoria y giro subjetivo, una discusión (2012).

Marianne Hirsch ha trabajado en profundidad sobre el término postmemory, atravesándolo con problemáticas de fotografía, historieta y otras producciones culturales. Hirsch (2008) considera que los hijos de sobrevivientes de hechos traumáticos colectivos se conectan de manera tan fuerte con los recuerdos del pasado de sus padres y/o familiares que definen esa conexión profunda como memoria. Esa memoria es, entonces, transmisible entre ambas generaciones, pero, al mismo tiempo, es distinta del recuerdo de los sobrevivientes. Para el análisis de este proceso, ella va a destacar la conjunción de tres elementos predominantes en la estructura de la posmemoria en el período posterior a la Segunda Guerra Mundial: la memoria, la familia y la fotografía. Algunas de sus publicaciones en donde trabaja sobre la posmemoria son Family Frames: Photography, Narrative, and Postmemory (1997), The Familial Gaze (1999), Time and the Literary (2002) y Teaching the Representation of the Holocaust (2004). Por otro lado, Beatriz Sarlo (2012) cuestiona la necesidad de acuñar la noción de posmemoria debido a que considera que las características teorizadas por Marianne Hirsch y James Young para definir el concepto no son lo suficientemente específicas y que, por lo tanto, sostener dicha noción se transforma en un impulso de inflación teórica más que en una necesidad justificada. Sin hacer un uso acrítico del concepto, la noción de posmemoria recorta de forma operativa, dentro del amplísimo espectro de la memoria, un mundo específico en torno a la generación de

\footnotetext{
${ }^{3}$ Esta era se enmarca en la década del 80 por la intensificación de las prácticas en torno a la memoria a partir, en gran medida, del debate sobre la experiencia de la Shoah, y, en el caso latinoamericano, de las dictaduras del Cono Sur - colocando al siglo XX como la era de guerras, genocidios, totalitarismos y crímenes de lesa humanidad.
} 
hijos. En el caso argentino los hijos de detenidos-desaparecidos durante la última dictadura cívico-militar argentina han trabajado de forma extensa e intensa la memoria de sus padres con producciones culturales y artísticas que los identifican y en la cual plantean especificidades (y distanciamientos) respecto a la memoria familiar de hechos traumáticos. Hay una bibliografía creciente con respecto a las construcciones identitarias de los hijos de desaparecidos. Prividera plantea tres "modelos" de hijos según su forma de relacionarse con el pasado traumático: hijos "replicantes" que se quedan encerrados en las historias de los padres, hijos "frankensteinianos" que quieren escapar a su origen y la postura intermedia de "mutantes", que "asumen su origen pero no quedan presos de él." (2009, s/p.). En esta línea son importantes los aportes de Ana Amado (2009), Gabriel Gatti (2011), Luis Ignacio García (2011) entre otros -a lo largo de la tesis veremos que son otras las problemáticas identitarias que atraviesan los hijos de exiliados. Se destacan tres disciplinas con gran cantidad de producciones por parte de hijos de desaparecidos: el cine, con la película Los rubios (2005) de Albertina Carri, $M$ (2007) de Nicolás Prividera, Papa Iván (2000) de María Inés Roqué, entre muchos otros; la fotografía a través de diversos proyectos de Lucila Quieto, Verónica Maggi, Gerardo Dell' Oro, Camilo Pérez del Cerro, Diego Aráoz, Gabriela Bettini, etc., y la literatura, como por ejemplo Los topos (2008) de Félix Bruzzone, La casa de los conejos (2008) de Laura Alcoba y Pequeños combatientes (2013) de Raquel Robles.

Por otro lado, en la década de 1990, junto con la incorporación cada vez mayor de la Historia Reciente a la Historia Académica, se incluye la investigación sobre el exilio político al campo del pasado reciente. Para acercarnos al tema, Silvina Jensen (2011) aborda ciertas características específicas que ha tomado el fenómeno en Argentina generado por la última dictadura cívico-militar (1976-1983) y su período previo $^{4}$. Con respecto al caso más específico del exilio político argentino en México, hemos partido de los exhaustivos análisis de Pablo Yankelevich en su libro Ráfagas de un exilio. Argentinos en México, 1974-1983 (2009) quien aborda desde el contexto, los problemas y tensiones del exiliado, las cifras del exilio, las instituciones que crearon, el caso de los asilados políticos, los conflictos y fracturas dentro de la militancia, e incluso las presencia y participación de los hijos en el exilio, entre otros temas. También hemos considerado otras publicaciones existentes sobre el exilio en México, entre ellas, México: el exilio que hemos vivido. Memoria del exilio argentino en México durante la

\footnotetext{
${ }^{4}$ No nos detendremos en realizar un estado de la cuestión detallado del exilio político dado que es un campo que ha crecido muchísimo en el último tiempo y excedería los objetivos de la presente tarea.
} 
dictadura 1976-1983 de Jorge Bernetti, y Mempo Giardinelli (2003), Seamos felices mientras estemos aquí de Carlos Ulanovsky (2011), El exilio argentino en México a treinta años del golpe militar (2007) coordinado por Fernando Serrano Migallón y, de su autoría, “...Duras las tierras ajenas...” (2001), Un refugio en la memoria. La experiencia de los exiliados latinoamericanos en México (2002) de Eugenia Meyer y Eva Salgado.

En torno a la particular construcción identitaria argenmex, producto del cruce entre la cultura argentina y mexicana que comenzó a circular entre los exiliados políticos argentinos en México hay menos bibliografía, entre la que podemos mencionar los dos libros citados anteriormente -Yankelevich (2009) y Bernetti y Giardinelli (2003)-, la tesina de Burkart Noe Violeta y Miller Analía (2007) Argenmex, exiliados hijos, el artículo de Néstor García Canclini “Argentinos en México: una visión antropológica" (1998) y algunas partes de distintos libros como es el caso de Seamos felices mientras estemos aquí (2011) de Carlos Ulanovsky. A partir del estudio visualizamos que, por un lado, se encuentra la generación adulta que se autoidentifica como argenmex desde un lugar de empatía afectiva hacia lo mexicano -y, especialmente, una vez retornada al país de origen se tradujo en una forma de melancolía por el alejamiento ahora de México. Por otro lado, se encuentra la generación de hijos de esos padres que absorbieron de manera directa tanto la cultura argentina -desde el núcleo familiar- como la cultura mexicana -en el jardín de infantes, la escuela y espacios de sociabilización por fuera del seno familiar. Existen también distintas producciones audiovisuales que abordan de una $\mathrm{u}$ otra manera esta construcción identitaria argenmex: el documental Argenmex. 20 años. La historia ésta con dirección de Jorge Denti, (1996); el documental Argenmex, exiliados hijos dirigido por Violeta Burkart Noe y Analía Miller (2007); la serie Argemex dirigida por Jorge Denti, una coproducción del Canal 22 de México y el Canal Encuentro de Argentina, realizada en ocho capítulos dedicado a distintas personalidades argenmex (Néstor García Canclini, Tununa Mercado y Noé Jitrik, Juan Gelman, Emilia Ferreiro, Hector Cámpora, Raquel Tibol, Gregorio y Marta Selser, Rolando Garcia); el capítulo de Historias Debidas Latinoamérica en donde la periodista Ana Cacopardo entrevista a Tania Ramirez. Y otras producciones que si bien no tratan directamente lo argenmex, se relacionan con la temática como por ejemplo Papá Iván de María Inés Roqué (2000), Encontrando a Victor de Natalia Bruchstein (2004); De dolor y esperanza. El asilo un pasado presente (2002) dirigida por Guadalupe Rodríguez de Ita, Silvia Dutrénit 
Bielous y Carlos Hernández Marines; Esta voz entre muchas dirigido por Humberto Ríos (1979); Juan Gelman y otras cuestiones de Jorge Denti (2006); Montoneros, crónica de una guerra de liberación con dirección de Cristina Benítez (seudónimo de Ana Amado) y Hernán Castillo (seudónimo de Nicolás Casullo) (1976); Te extraño (2010) con dirección de Fabián Hofman; Pasaportes (1997) de Inés Ulanovsky.

Si las investigaciones sobre las memorias particulares de la segunda generación en Argentina se han focalizado principalmente en el estudio de la producción fílmica, narrativa y fotográfica, aquí abordaremos otros medios artísticos menos transitados teóricamente en su relación con las memorias traumáticas y el exilio en México. Parte del aporte específico de esta tesis se centra, entonces, en la reflexión sobre proyectos interdisciplinares donde lo fotográfico, lo corporal y lo objetual son centrales para analizar la trasmisión de memorias. Pensamos que estos medios -concepto tomado de Belting (2012)- son propuestos por los artistas porque tienen relaciones intrínsecas con las memorias traumáticas, consideramos que imagen y medio son dos caras de la misma moneda y que "el apreciado discurso acerca de forma y materia, en el que se continúa la antigua discusión respecto de espíritu y materia, no puede ser aplicado al medio portador de la imagen", ya que "no se puede reducir una imagen a la forma en que la recibe un medio cuando porta una imagen: la distinción entre idea y desarrollo es igualmente poco válida para la relación entre imagen y medio.” (Belting, 2012 p. 16). Resulta significativo, entonces, desde estas concepciones teóricas, y con las problemáticas propias que integran el corpus de proyectos seleccionados -son artistas que pertenecen a la segunda generación y desde una muy temprana edad han vivenciado el exilio político en México- indagar en las producciones artísticas de Mercedes Fidanza, Soledad Sánchez Goldar, Inés Ulanovsky, Magdalena Jitrik, Tomás Alzogaray Vanella, Federico Joselevich Puiggrós y Liza Casullo.

\section{Recorridos}

La tesis se estructura en dos partes. En la primera abordamos las particularidades del exiliado político en México, entre ellas, la construcción identitaria argenmex; las problemáticas específicas de la segunda generación de exiliados; la relación entre la memoria y las prácticas poético-testimoniales y el lugar que ocupan estas prácticas en la historia del arte y la construcción colectiva del pasado. En esta instancia, conformada por los capítulos uno y dos, intentamos generar herramientas teóricas que nos ayuden a 
analizar y problematizar en profundidad las producciones artísticas planteadas en la segunda parte de la tesis. En los capítulos tres, cuatro y cinco, agrupamos, entonces, las diferentes producciones artísticas a través del tipo de medio -teniendo en cuenta que en la mayoría de las obras se conforman desde lo multidisciplinario-: lo fotográfico en el capítulo tres, con Fotos lavadas (2005-2010) de Soledad Sánchez Goldar y Fotos Tuyas (2001-2002) de Inés Ulanovsky; lo corporal en el capítulo cuatro, con Tres Bellas Heridas (2007) de Soledad Sánchez Goldar y la trayectoria de Magdalena Jitrik y su paso por el Taller Popular de Serigrafía (2002-2007); y lo objetual en el capítulo cinco, con Árbol del desexilio (2006-2010) y 7Historias (2008) de Mercedes Fidanza, Un niño de 30 años (2006) y El niño que odia (2007-2011) de Tomás Alzogaray, y El Objeto del Exilio (2013) de Liza Casullo y Federico Joselevich Puiggrós.

En el primer capítulo "Exilio político en México y segunda generación de argenmex" abordamos algunas de las problemáticas que atraviesan la primera y segunda generación de exiliados. Luego de una breve contextualización sobre esta migración política, reflexionamos en torno a la compleja relación entre los argentinos y los mexicanos y la construcción identitaria argenmex -y sus usos y apropiaciones diferenciales tanto para la primera generación como para la segunda. Finalizando el capítulo, vemos cómo estas particularidades de los hijos de exiliados, tanto su carácter de "hijos" de padres exiliados -víctimas de la última dictadura cívico-militar argentinacomo su sentimiento de "bicho raro" y la inestabilidad identitaria producida por el doble destierro, han influido en muchos de ellos para armar espacios compartidos en donde anclar su identidad -tanto en el mundo de la militancia política y/o en el de las artes, y/o en el de los argenmex.

En "Memoria, testimonio, ¿pos?memoria y arte" nos enfocamos más específicamente en las relaciones entre la memoria y el arte. Estudiamos, a partir de Paul Ricœur (2004) y Giorgio Agamben (2002), las características del testimonio -y sus múltiples funciones que exceden el espacio de la Historia y la Justicia. Desde estas reflexiones, abordamos la compleja relación entre lo artístico y lo testimonial en las prácticas poéticas-testimoniales (Amado, 2009) de la segunda generación, analizando su doble pertenencia de verdad/ficción. En este contexto, introducimos los debates sobre la noción de posmemoria -referente en un inicio a la generación posterior a la de los sobrevivientes de la Shoah y luego a la generación de hijos de las dictaduras de Estado del Cono Sur. Hacia el final del capítulo, reflexionamos sobre el estudio de las imágenes y la Historia del arte en relación al campo de la historia y de los estudios de memoria. 
Para esto, mencionamos una serie de reflexiones de pensadores heterogéneos que han cuestionado los supuestos básicos de la Historia del arte tradicional y han dirigido su atención a la memoria.

Dentro de la segunda parte de la tesis, comenzamos con el abordaje de lo fotográfico en distintas producciones artísticas como un lugar específico por donde transmitir las memorias traumáticas. Para esto, vemos en un primer momento los roles fundamentales que ha cumplido la fotografía fuera de su uso artístico en relación al trauma colectivo y la historia reciente argentina, entre ellos, la foto como testimonio/prueba y herramienta de denuncia de las desapariciones forzadas de personas por parte de los organismos de derechos humanos, la foto como reliquia del ser querido conservada por un familiar, la foto del álbum familiar llevada al exilio como manera de acercar a un pariente o amigo lejano. En un segundo momento, nos focalizamos especialmente en lo fotográfico dentro de dos propuestas artísticas de hijas de padres exiliados en México: Fotos Lavadas (2005) de Soledad Sánchez Goldar y Fotos tuyas (2001-2002) de Inés Ulanovsky. Reflexionamos, entonces, en los nuevos usos y sentidos que habilitan estas fotos pertenecientes a propuestas artísticas, entre ellos, mostrar los rituales familiares en torno a las fotos que quedaron, habilitar la elaboración de trauma familiar, reponer la biografía del familiar desaparecido/asesinado, crear un tiempo condensado entre el que ya no está y el presente de los familiares y posibilitar el pasaje de lo privado a lo político.

En el cuarto capítulo profundizamos sobre lo corporal en las prácticas artísticas pertenecientes a la generación de hijos/as. Algunas de las preguntas que planteamos como guía son: ¿Por qué se realiza una performance artística para transmitir una historia familiar marcada por la violencia del terrorismo de estado?, ¿cuál es la relación entre cuerpo y memoria traumática? Trazamos un breve recorrido sobre la representación corporal de los desaparecidos en los primeros años de la posdictadura, en el marco de los movimientos de Derechos Humanos en Argentina y en acciones artísticas en América Latina, y profundizamos en las relaciones entre cuerpo, memoria traumática y performance artística -destacando la relación entre performance y resistencia cultural, lo corporal como materialidad afectada por el terrorismo de estado, la relación entre cuerpo, poética, política y memoria afectiva expresada en términos de micropolítica, y la confluencia de los mecanismos propios del trauma y los de la performance. A partir de estos supuestos teóricos reflexionamos sobre dos casos en particular de artistas exiliadas- de la segunda generación: la trayectoria de Magdalena Jitrik en el activismo 
artístico, puntualmente la experiencia en el Taller Popular de Serigrafía (TPS) -donde aparece el cuerpo en la calle, el cuerpo público y militante- y la performance artística Tres Bellas Heridas de Soledad Sánchez Goldar -donde se expone un cuerpo más íntimo y privado.

El objeto ocupa un lugar importante entre los exiliados políticos. En el último capítulo reflexionamos sobre las múltiples memorias del exilio político en México a través de las propuestas artísticas que presentan los objetos que han estado en tránsito: desde aquellas que "añoran" al país refugio como aquellas que plantean los conflictos que tuvo la segunda generación en el exilio. Estos objetos -ya que por ser pequeños y livianos han acompañado las valijas de la primera y segunda generación- son los protagonistas en: Árbol del desexilio (2006-2010) y 7Historias (2008) de Mercedes Fidanza, Un niño de 30 años (2006) y El niño que odia (2007-2011) de Tomás Alzogaray, y El Objeto del Exilio (2013) de Liza Casullo y Federico Joselevich Puiggrós. A lo largo del capítulo analizaremos, entonces, las propuestas artísticas teniendo presente las siguientes preguntas: ¿qué tipo de objeto aparece?, ¿qué memorias se representan?, ¿qué memorias del exilio construyen los objetos de las producciones artísticas?, ¿qué significa para la segunda generación de exiliados el "irse con lo puesto" de los padres?, ¿son los mismos objetos aquellos del "irse con lo puesto" a los "objetos del regreso/presente"?

Las imágenes también trazan un recorrido particular dentro de esta tesis. Antes de empezar a leer el capítulo 3, 4 y 5, nos encontramos con dos imágenes de las producciones visuales que luego analizamos. Además, hacia el final del escrito, tenemos un anexo con varias imágenes trabajadas en el texto. Creemos que esta organización visual apunta a no considerar a las imágenes como mera descripción del texto, sino que, al contrario, ayuda a establecer una primera relación visual con la propuesta artística para luego pasar al escrito. ${ }^{5}$

\section{Metodología}

El presente proyecto se enmarca en el cruce entre los campos de la Historia del Arte, los Estudios Culturales y el de los Estudios de Memoria e Historia Reciente. Mi propia formación estuvo atravesada por dos disciplinas diferentes: la Historia del Arte soy profesora en Historia de las Artes Visuales de la Facultad de Bellas Artes (UNLP)-,

\footnotetext{
${ }^{5}$ Las imágenes que integran la presente tesis han recibido la autorización de sus artistas para ser publicadas o han sido citadas de acuerdo al sitio de donde se han extraído.
} 
y la Memoria vinculada a la Historia reciente - esta tesis se radica en la Maestría en Historia y Memoria de la Facultad de Humanidades y Ciencias de la Educación (UNLP). La inter y la transdisciplina, entonces, me han ayudado a cruzar un conjunto de herramientas teóricas y metodológicas para estudiar las producciones visuales de los artistas pertenecientes a la segunda generación de exiliados políticos en México ${ }^{6}$.

Asimismo, han habido recientemente diferentes aperturas en el campo tradicional de la Historia del Arte -aperturas que integran herramientas y categorías teóricas de otros enfoques disciplinarios. El estudio de las imágenes en la presente tesis se enmarca más específicamente en el campo de estudios visuales o estudios culturalesvisuales sobre lo artístico ${ }^{7}$ (Brea, 2005, p. 7), un espacio en el que se integran aportes tanto de la sociología, la estética, la filosofía como de la antropología cultural, la teoría de los medios de comunicación, los estudios culturales, entre otros. También, los campos de estudios de memoria, historia oral, exilio y nueva historia, por su trayectoria más reciente en comparación con las disciplinas tradicionales, están conformados con múltiples enfoques y cruces conceptuales.

Pese a la complejidad que supone trasponer todos estos conocimientos, intentamos repensar, intercambiar y tomar prestadas ciertas categorías y problemas metodológicos sin perder la especificidad propia de los estudios visuales y de los estudios de memoria. Algunas de las preguntas que nos guiaron en este camino cruzado son: ¿qué tipo de memorias conforman las producciones artísticas?, ¿cómo se vinculan con los testimonios?, ¿cómo opera la relación entre "verdad” y "ficción”?, ¿qué especificidades tienen los medios artísticos para la transmisión/transformación de una memoria familiar y colectiva?, ¿cuál es la relación entre memoria, tiempo e imagen?, ¿Cuál es la relación entre imagen y memoria?, y ¿entre arte y memoria?, ¿Cómo dialoga/confronta la Memoria con la Historia del Arte?

En relación al tiempo transcurrido durante la investigación, podemos distinguir dos etapas: una primera inicial en donde realicé un estudio de campo en México

\footnotetext{
${ }^{6}$ Para ampliar sobre el enfoque interdisciplinar, consultar el capítulo: Basso, M. Florencia, "Indisciplinar las artes: memoria e imagen" en: Indisciplinas. Reflexiones sobre prácticas metodológicas en Ciencias Sociales. Diálogos entre investigadores/as en formación de la UNLP, IICom / Club Hem (en prensa).

${ }^{7}$ Estos estudios los define Brea en la siguiente cita: "Tan pronto como tales "estudios culturales sobre lo artístico" se constituyen sobre bases críticas, se derrumba el muro infranqueable que en las disciplinas dogmáticamente asociadas a sus objetos separaba a los artísticos del resto de los objetos promotores de procesos de comunicación y producción de simbolicidad soportada en una circulación social de carácter predominantemente visual. De tal manera que dichos estudios críticos sobre lo artístico habrán de constituirse, simplemente, como "estudios visuales" -o si se quiere, y valga esta paráfrasis como la mejor descripción que en mi opinión puede darse, estudios sobre la producción de significado cultural a través de la visualidad." (Brea, 2005, p. 7).
} 
(Distrito Federal) direccionada a reconstruir las prácticas relacionadas con el arte visual de los argenmex, a través de la recopilación de fuentes primarias en el período comprendido entre los años 1974-1983. Algunas de estas fuentes consultadas fueron la revista Controversia publicada por un grupo reconocido de exiliados; los periódicos mexicanos que incorporaron a exiliados en sus distintas áreas de trabajo como por ejemplo el UNOMÁSUNO, el Excélsior y El Día; los archivos de los museos o centros culturales donde se realizaron actividades artísticas como exposiciones, ferias o conmemoraciones -por ejemplo la exposición "Argentina, represión y esperanza" realizada en el Museo Universitario del Chopo en 1980 en el Distrito Federal. Asimismo me encontré con distintas personas que compartieron sus testimonios orales sobre sus vivencias del exilio, y realicé una entrevista a Néstor García Canclini y una a Pablo Yankelevich en torno a los argenmex y el circuito artístico. También, durante el tiempo transcurrido en México, me familiaricé con costumbres de la cultura mexicana que luego -de forma más subyacente- me ayudaron a comprender cuestiones básicas de la relación entre los argentinos y mexicanos. En la segunda etapa, ya en Argentina, pude sistematizar toda esa información y orientar la investigación a las producciones visuales de la segunda generación de artistas exiliados en México y que habían retornado a la Argentina. Analicé, entonces, los proyectos artísticos (fuentes primarias) relevados pertenecientes a la generación de hijos de exiliados políticos en México, poniéndolos en diálogo con las declaraciones de los propios artistas en entrevistas, publicaciones en páginas web, etc.; como en reseñas, críticas de arte, material de difusión, notas periodísticas, registros fotográficos, videos, entre otros materiales (fuentes secundarias). Realicé entrevistas semi-estructuradas a diferentes personas ${ }^{8}$ : varios de los artistas que abordé en la tesis -Magdalena Jitrik, Inés Ulanovsky, Tomás Alzogaray Vanella, Federico Joselevich Puiggrós- y a otras personalidades argenmex como Ana Jaramillo. Asimismo realicé varias consultas teóricas y bibliográficas con quienes cursé seminarios especializados en las áreas de memoria, historia reciente y arte -Ana Longoni, Silvina Jensen, Marina Franco, entre otros. A partir de las discusiones en las cursadas, de las correcciones de los trabajos finales de la Maestría, de las presentaciones en encuentros,

\footnotetext{
${ }^{8}$ Con respecto a la realización de las entrevistas, nos guiamos por los consejos teóricos de Rosana Guber: "[...] el investigador se propone armar un marco de términos y referencias significativo para sus futuras entrevistas; aprende a distinguir lo relevante de lo secundario, lo que pertenece al informante y lo que proviene de sus propias inferencias y preconceptos, contribuyendo a modificar y relativizar su perspectiva sobre el universo cultural de los entrevistados [...] Los informantes reformulan, niegan o aceptan, aun implícitamente, los términos y el orden de las preguntas y los temas, sus supuestos y las jerarquizaciones conceptuales del investigador. De este modo, el investigador hace de la entrevista un puente entre su reflexividad, la reflexividad de la interacción y de la población.” (2001, p. 92).
} 
jornadas, congresos de diferentes universidades $y$, muy especialmente, de los constantes intercambios con Leticia Muñoz Cobeñas - mi directora de tesis-, Daniel Lvovich -mi codirector de tesis- y María de los Ángeles De Rueda -mi directora de beca de investigación de UNLP- he estado continuamente guiada y apoyada en la realización de esta tesis. 


\section{CAPÍTULO 1. EXILIO POLÍTICO EN MÉXICO Y SEGUNDA GENERACIÓN DE ARGENMEX}

En este capítulo inicial nos proponemos abordar el contexto de la historia reciente argentina, específicamente el que atraviesan las dos generaciones afectadas padres e hijas/os- por la última dictadura cívico-militar argentina y el exilio político en México. Se puntualizará en ciertos ejes que ayudarán a reflexionar sobre la segunda generación de exiliados políticos y sus producciones artísticas, entre ellos: la especificidad del exilio político argentino en México; la compleja relación entre los argentinos y los mexicanos; la construcción identitaria argenmex -y sus usos $\mathrm{y}$ apropiaciones diferenciales tanto para la primera generación como para la segunda-; las problemáticas propias de los hijos/as -y sus diferencias con respecto a las de sus padres; y el pasaje de hijos/as de exiliados a La Juventud Argentina en el Exilio e Hijas e Hijos del Exilio.

\section{En torno a la especificidad del exilio político argentino en México}

Los exilios políticos ${ }^{9}$ han sido una práctica constante a lo largo de la historia argentina. Sin embargo, con la escalada represiva desplegada durante el tercer peronismo (encabezada por Perón en 1973 y continuada, tras su fallecimiento, por María Estela Martínez) y, especialmente, después del golpe militar de marzo de 1976 y la instauración de la dictadura cívico-militar argentina (1976-1983); el mecanismo de

\footnotetext{
${ }^{9}$ El concepto de exilio es, en palabras de Marina Franco, polisémico y ambiguo. Retomamos algunas de las preguntas de Marina que nos hacer reflexionar sobre el uso de este término: “¿Cuál es el límite entre exilio y migración cuando las necesidades de inserción en un mercado de trabajo y las estrategias de supervivencia y preocupaciones cotidianas del exiliado son similares a las de cualquier migrante, o cuando el migrante voluntario previo se politiza o descubre que ya no podría volver a su país si lo deseara?". (...) suele suponerse que la migración política o exilio define la situación de quienes salieron de su país por una decisión voluntaria o no, pero en cualquier caso no deseada, forzada por las circunstancias políticas que los afectaron como miembros de una comunidad. ¿Pero cómo se determina el carácter forzado de esas circunstancias? ¿A partir de qué elementos se puede hablar de motivos políticos?, ¿el miedo lo es? ¿cuál es la diferencia entre un exiliado político y un exiliado económico cuando ambos son víctimas de un régimen cuyas políticas de gobierno son expulsivas?" (2008, pp. 19, 20). También citamos a Soledad Lastra: “(...) el desplazamiento migratorio original de salida del país de origen se inicia bajo circunstancias en las cuales la decisión de emigrar se asume en un contexto coercitivo que deja un estrecho margen de evaluación racional. El exiliado entonces, se ubica en una frontera difusa entre la voluntad y la obligatoriedad de la salida, en donde la decisión se asienta en la necesidad de poner a salvo la vida y la integridad de la persona por sobre las expectativas instrumentales que se podrían contemplar en un caso de migración económica." (2013, p. 324). A partir de todos los estudios existentes en el campo y por razones operativas en la presente tesis usaremos el término exilio político para referirnos a nuestro caso.
} 
expulsión de argentinos del país adquirió una dimensión mayor. Este exilio, consecuencia del terrorismo de estado que cometió múltiples violaciones a los derechos humanos como la persecución, detención, tortura sistematizada, manipulación de información, apropiación de niños y desaparición forzada de personas, fue un proceso colectivo, es decir, una sumatoria de exilios individuales o familiares que se produjeron de diferentes formas (legal, clandestina o permutando el encierro por el exilio en ciertas ocasiones ${ }^{10}$ ) y de manera constante durante una década aproximadamente ${ }^{11}$ (Yankelevich, 2009). Este exilio político se diferencia de los anteriores por varias razones: la amplia cifra de exiliados, su extensión en el tiempo, su transversalidad social -aunque en diferente cantidad según el sector social-, el hecho de haber afectado a organizaciones de la izquierda armada y a una amplia militancia social, profesional, sindical y barrial, y por adoptar la forma diaspórica, en el sentido de que se ha generado una dispersión de argentinos por varias partes del mundo (Jensen, 2011). Como adelantamos, esta novedad no significa que no exista una historia previa de los exilios en Argentina, sino que, al contrario, ha sido parte de "una práctica de control o eliminación del enemigo político de larga tradición" (2011, p. 3), desde la conformación del estado-nación.

Para ahondar en las problemáticas de los exiliados políticos es necesario tener en cuenta las múltiples aristas que emergen al abordar este tema, entre ellas, la mirada comparativa entre dos geografías sociales, políticas y culturales diversas; la construcción de la familia en donde los padres y los hijos/as se diferencian -por estar, en gran medida, en distintas etapas de la vida- en la forma que enfrentan el intercambio cultural y en cómo se conforman identitariamente; las particularidades del grupo exiliado -con sus vivencias traumáticas- y las redes e intercambios que conforman en el

\footnotetext{
${ }^{10}$ En el gobierno de Isabel de Perón existió el llamado "Derecho de opción" donde se podía permutar el encarcelamiento por el exilio.

${ }^{11} \mathrm{Si}$ bien a partir de distintas investigaciones se propuso un número aproximado de medio millón de personas emigradas de la Argentina a lo largo de la segunda mitad de siglo XX, Yankelevich (2009) alerta sobre las dificultades para cuantificarlas y para separar el exilio político de esa emigración. Las fuentes disponibles para la cuantificación son pocas y no explicitan en muchos casos si se trata o no de un exilio político tanto en la salida del país como en los registros de ingreso al país receptor -fueron muy pocas las personas asiladas y refugiadas en las embajadas extranjeras en Argentina. Sin embargo, algunas estadísticas se pueden presentar: los países de recepción con mayor cantidad de perseguidos políticos fueron Brasil, México, Venezuela y Cuba en América Latina; y España, Italia, Francia y Suecia en Europa, y el período como más cantidad de exiliados fue entre los años 1970 y 1980. También destaca, a partir del Instituto Nacional de Migración, ciertas características de los exiliados políticos del período 7683: eran en su mayoría hombres adultos ( 20 y 39 años), ateos, provenientes de la Capital Federal y Provincia de Buenos Aires, seguido de Córdoba y Rosario, profesionales, académicos y estudiantes, (un $40 \%$ con grado o posgrado universitario, y una de las profesiones que ocupó el primer lugar fue la psicología), se duplicaron los artistas y artesanos en este período con respecto al anterior, y se cuadriplicaron la cantidad de mujeres profesionales.
} 
país de destino; el significado que adquiere el retorno al país expulsor tanto para padres como para hijos/as, entre otras.

Silvina Jensen (2011) expone ciertas características específicas que ha tomado el fenómeno en Argentina generado por la última dictadura cívico-militar (1976-1983) y su período previo. La autora alerta sobre ciertas cuestiones metodológicas y teóricas a la hora de analizar el exilio: al ser un objeto poliédrico y móvil es necesario abordarlo desde distintos niveles y escalas de análisis múltiples (local, nacional, regional, internacional, trasnacional), y desde la sociedad expulsora y la sociedad de destino (generando en el exiliado una dualidad tanto geográfica como temporal, política, cultural, identitaria). A su vez, debido a las diversas trayectorias políticas, laborales, culturales de los desplazados y a las distintas subjetividades existentes frente a un mismo hecho, se hace necesario pensar los exilios como fenómenos plurales y con una variabilidad intrínseca ya que sus formas mutan constantemente a lo largo del tiempo conformando distintas etapas, ritmos e intensidades- abarcando incluso a otras generaciones. Es importante, además, reconocer los distintos sentidos otorgados al concepto: la referencia a la condición humana universal (el "yo exiliado") o a la preocupación intelectual en relación a su estado de no pertenencia, marginalidad, exterioridad, (los “exilios existenciales", “existencias exiliadas”) a los exilios políticos.

Partiendo de estas premisas, nos interesa profundizar en el caso del exilio político argentino en un país receptor en particular: México. Surgen, entonces, algunas preguntas claves para poder guiar el análisis y comprender mejor el caso de este grupo de exiliados: ¿cuál es la especificidad de este exilio? ${ }^{12}$; ¿por qué muchas personas eligieron a México como país de destino?; ¿qué imaginario estaba en juego al elegir ese país?; ¿cómo fueron los cruces culturales, políticos, identitarios entre argentinos y mexicanos?; ¿qué tipo de tensiones hubo entre argentinos y mexicanos?; ¿qué significa "ser argenmex"?

México fue uno de los principales países de residencia del exilio argentino en América Latina. Entre los años 1974-1983 se estima que llegaron alrededor de casi cinco mil exiliados argentinos a México. Yankelevich (2009) distingue tres corrientes

\footnotetext{
${ }^{12}$ Yankelevich remarca que el exilio de argentinos en México tuvo sus propias particularidades: "El sentido de pérdida consustancial a toda condición de exilio, parece haber sido procesado de forma especial por parte de quienes se dirigieron a México. ¿Cuáles son las claves para entender la manera en que una colectividad golpeada y profundamente sacudida por el destierro, terminó valorando las vivencias mexicanas como fundamentales en el proceso de reconfiguración identitaria? La respuesta no se agota en el hecho de una nación que abrió sus puertas permitiendo salvar vidas o resguardar libertades, sino y sobre todo se vincula al conjunto de compensaciones desenvueltas en la diaria cotidianidad de los exiliados." (2009, p. 288).
} 
migratorias en este período: una inicial (1974-1975) en donde llegaron los primeros exiliados políticos, una segunda (1976-1979) en donde se incrementaron las cifras de los mismos, y una última (1980-1983) integrada tanto por los perseguidos políticos que viajaban desde Argentina a México como de aquellos que habían iniciado su exilio en otros países pero que luego se incorporaron a México, junto con los emigrados por razones económicas -debido a las consecuencias de la crisis económica que se desencadenó a finales de 1979 en Argentina. A su vez, en México a partir de 1980 se estableció de forma permanente el Alto Comisionado de las Naciones Unidas para los Refugiados (ACNUR) y fue creada la Comisión Mexicana de Ayuda a los Refugiados (COMAR) para gestionar el arribo masivo de guatemaltecos, lo cual benefició de forma indirecta a los asilados territoriales argentinos a partir de 1979-1980, incrementándose el número de los mismos. En relación al perfil socioeconómico, la mayor cantidad de exiliados políticos pertenecían a las clases medias (una gran cantidad eran originarios de Capital Federal o de la provincia de Buenos Aires) y, especialmente, al sector universitario -profesionales, académicos y estudiantes-, debido a que: “(...) la dictadura identificó a intelectuales y a hombres de la cultura en general como agentes privilegiados de la ‘subversión.'” (2009, p. 48). Yankelevich destaca que si bien los obreros fueron un sector muy perseguido durante la dictadura cívico-militar, no tuvieron un lugar semejante en el exilio tanto por las dificultades económicas que podrían haber tenido como por la falta de información migratoria que desdibuja las ocupaciones de estos sectores. En México, se instalaron principalmente en el Distrito Federal y su área metropolitana, seguidos por Guadalajara, Puebla y Monterrey.

Yankelevich expone cuatro premisas en relación a las particularidades del caso del exilio político argentino en México: en primer lugar, los desterrados eran perseguidos políticos que consideraban a México, en muchos casos, como el lugar para preservar la libertad y la vida, y, a la vez, como un sitio transitorio, ya que, recién llegados, no pensaban en instalarse definitivamente; en segundo lugar, los argentinos tuvieron una amplia inserción laboral y profesional en México, especialmente aquellos que ya contaban con título profesional o antecedentes de trabajo ${ }^{13}$; en tercer lugar, el espacio cultural que acogió a los recién llegados ayudó a generar puentes con el país de

\footnotetext{
${ }^{13}$ Con respecto a los empleos, los argentinos profesionales consiguieron trabajo muy rápidamente, en especial aquellos que llegaron con el gobierno de Luis Echeverría. Algunos también pudieron concluir sus carreras universitarias y sus estudios de posgrado.
} 
refugio $^{14}$; y, la última premisa se basa en el trato complejo, dual y paradojal, entre la solidaridad hacia los perseguidos políticos y la reticencia hacia el extranjero ${ }^{15}$. Esta dualidad conformada por el sentimiento tanto de admiración como de temor por parte del mexicano hacia el extraño se corresponde, según el autor, con la manera en que se ha procesado la historia y la memoria en México. Basada en el mito fundador de la conquista, esta memoria es trasladada al extranjero en forma de resistencia, convirtiendo a la extranjería en amenaza o al extranjero en posible invasor profundizaremos en estas problemáticas a lo largo del capítulo.

Además de esta forma de relación ambivalente por parte de los nativos hacia los recién llegados, surgen otras discrepancias, tensiones y paradojas en el vínculo entre lo argentino y lo mexicano. Una de estas disonancias se refleja en la elección de México como país receptor dentro de América Latina: por una parte aparece en los testimonios que Yankelevich analiza "la voluntad de no abandonar América Latina" y México se perfilaba como un país con marcas latinoamericanas ${ }^{16}$ _"para mí (...) México era América, era la existencia de América que en Argentina estaba borrada” (2009, p. 323). Pero, por otra parte, poco se conocía de la historia, costumbres y cultura mexicanas, exceptuando las imágenes más estereotipadas como María Félix, Pedro Vargas y a Cantinflas, los boleros, el pasado prehispánico, la Revolución mexicana, Emiliano Zapata y Pancho Villa, entre otras.

También surgen actitudes opuestas dentro del ámbito afectivo por parte de los exiliados políticos para con los mexicanos. Por un lado hubo un "espíritu de gueto" presente en varios espacios entre las familias de exiliados: los hogares (como el complejo habitacional Villa Olímpica en el Distrito Federal, el "gueto máximo" de argentinos), los colegios (en algunos casos eran los mismos que los fundados por los refugiados republicanos españoles, como El Colegio Madrid, la escuela Herminio Almendros o el Centro Activo Freire) y las vacaciones con destinos iguales entre distintas familias exiliadas. Este refugio entre sus congéneres, para "preservar" su

\footnotetext{
${ }^{14}$ Por ejemplo en la editorial de Siglo XXI Editores se dio cobijo a un grupo de exiliados. Por su parte Mauricio Achar, el propietario de la Librería Gandhi, gestó un espacio de apoyo e intercambio cultural con los exiliados

${ }^{15}$ Cfr.: “(...) Ser extranjero, ser diferente entre diferentes es complicado, pero puede serlo más en una nación donde de manera permanente se remarca esa diferencia a partir de la tradicional pregunta: ¿usted no es de aquí, verdad?, fórmula con la que el mexicano rompe el silencio cuando enfrenta a un extranjero. Sucede que en México, de manera contradictoria, convive la solidaridad hacia los perseguidos con una marcada reticencia hacia quien no ha nacido en su territorio [como por ejemplo el calificativo de "güero/a"]". (Yankelevich, 2009, p. 189).

${ }^{16}$ Esta latinoamericanidad era, además, una bandera de la izquierda argentina del momento.
} 
origen y pertenencia -y que generaba, en ocasiones, prejuicios hacia los mexicanos-, buscaba "restituir el sentido a una vida fracturada por la represión y el destierro. Esa fractura sólo en parte pudo ser contenida por el gueto, ya que si bien el mundo de lo privado se estructuraba desde la argentinidad, el "afuera" no podía ser más que mexicano." (Yankelevich, 2009, p. 320).

Sin embargo, a pesar de esta polarización entre el adentro argentino y el afuera mexicano, se dio un gran intercambio cultural dentro de la prensa, las publicaciones y las distintas actividades mexicanas: varios exiliados se sumaron a tareas editoriales ${ }^{17}$, muchos escritores como Noé Jitrik, Mempo Giardinelli, David Viñas, Humberto Constantini, Pedro Orgambide, Raúl Dorra, Alberto Adellach, Jorge Boccanera colaboraron en revistas políticas y culturales como Plural, Vuelta, El Cuento, Proceso y Nexos; se realizaron actividades solidarias como la publicación del libro Desde la cárcel -en el que se reprodujeron relatos, dibujos y poemas escritos por presos políticos en distintas cárceles argentinas. A su vez las editoriales mexicanas publicaban libros que estaban prohibidos en Argentina. En el terreno del cine, la periodista argentina Ana María Amado informaba sobre la censura y algunas nuevas figuras del cine argentino. También hubo giras de músicos y cantantes argentinos como Mercedes Sosa, Astor Piazzola, Les Luthiers, Atahualpa Yupanqui, Susana Rinaldi y las orquestas de tango de Osvaldo Pugliese y de Mariano Mores ${ }^{18}$. Yankelevich afirma: “[q]uizás como en ningún otro país de destino, el exilio de intelectuales, escritores y artistas, personas del teatro y del cine encontró en México un amplio espacio donde continuar sus trabajos." (2009, p. 268).

Por otro lado se comenzó a conformar desde el inicio del exilio una construcción identitaria híbrida -sobre todo en el caso de los hijos de exiliados- que agrupaba tanto

\footnotetext{
${ }^{17}$ En la participación de exiliados en trabajos editoriales, se encuentran José Arico y Jorge Tula en la editorial de Siglo XXI, Ulises Guiñazú como traductor de distintos libros de México, Ricardo Nudelman como fundador de la editorial Folios, así como Guillermo Schavelzon en la creación de Nueva Imagen, y Orgambide, Viñas y Constantini en Tierra del Fuego (donde publicaron la antología 20 cuentos del exilio coordinada por Costantini).

${ }^{18}$ Yankelevich (2009) da cuenta de la variedad de las disciplinas culturales representadas en el exilio por artistas argentinos: en el área musical se encontraban Miguel Ángel Estrella, el dúo Nora y Delia, el grupo Nacimiento, Naldo Labrín, el conjunto Los Huincas, Liliana Felipe, Nacha Guevara, Lito Nebbia -con su canción sobre el destierro "solo se trata de vivir"; en el campo de la dramaturgia estaba Alberto Adellach; en la actuación de teatro popular participaban Arti Barrionuevo, Shuto Díaz, Horacio Acosta, Mary Bluno, Héctor Beacon, Francisco Giménez; y en el ámbito del cine se encontraban Nerio Barberis, Jorge Denti, Adolfo García Videla, Nicolás Amoroso. Como resultado del encuentro de creadores mexicanos con artistas exiliados argentinos, uruguayos y chilenos de otras dictaduras se conformaron el Grupo Sur, el Cuarteto de Tango y la compañía del teatro El Galpón, entre otros proyectos. Por otro lado, Néstor García Canclini se encargó de la crítica de la primera exposición en México del artista plástico León Ferrari.
} 
las costumbres argentinas como las mexicanas, y que luego se cristalizó en la palabra argenmex.

A su vez, la libertad de lo que antes era prohibido en el país de origen "abrió el camino hacia percepciones que, en la mayoría de los casos, promovieron visiones idealizadas del país refugio" (Yankelevich, 2009, p. 330). Se buscó un nuevo espacio identitario de exiliados y mexicanos donde el componente latinoamericano jugó un rol fundamental -según un testimonio a la salida del aeropuerto había un cartel que decía "Hermano Latinoamericano: Bienvenido" (p. 325)- así como también el hecho de compartir el mismo idioma ${ }^{19}$. También es importante tener presente que México fue "la Meca del exilio en América Latina” (p. 330) ya que antes de que llegara la migración política argentina, habían llegado los chilenos, los uruguayos, los guatemaltecos, los dominicanos, los haitianos, los nicaragüenses, entre otros; y anteriormente los republicanos españoles. ${ }^{20}$

Estas actitudes de apertura o cierre de los argentinos para con los mexicanos también se notó en las diferentes propuestas de los centros culturales gestionados por exiliados -que, a su vez, pertenecían a distintas organizaciones políticas ${ }^{21}$ : por ejemplo el Centro de Estudios Argentinos Rodolfo Ortega Peña del Comité de Solidaridad con el Pueblo Argentino (COSPA) a cargo de Rubén Dri (y Pedro Orgambide encargado del área de letras) tenía una impronta de denuncia política -entre sus actividades se daban

\footnotetext{
${ }^{19}$ Marina Franco explora brevemente, al contrastar el caso del exilio argentino en Francia con otros destinos, la diferencia en los códigos sociales establecidos entre argentinos y mexicanos o argentinos y españoles en relación a lo sucedido con los franceses: "En esto es probable que el idioma [en Francia] haya desempeñado un papel limitador de primera magnitud, junto con el hecho de tratarse de una sociedad de códigos menos espontáneos, más "fríos", que aquellos habitualmente asociados a españoles y mexicanos, por ejemplo" (2008, p. 292).

${ }^{20}$ Además del término Argenmex, existen otros que exponen el cruce de culturas nacionales entre diferentes exiliados políticos, por ejemplo urumex, chilemex o argenven.

${ }^{21}$ Yankelevich (2009) expone de manera contundente -apoyándose en testimonios, publicaciones, etc.cómo en el exilio argentino en México hubo confrontaciones, fracturas y disputas dentro de la izquierda política. Los exiliados que llegaron a México a mediados de 1974 conformaron, a partir de reuniones en casas particulares, la Comisión Argentina de Solidaridad (CAS), integrada por Esteban Rigui, Rodolfo Puiggrós, Noé Jitrik, Rafael Pérez y César Calcagno, entre otros. Sin embargo, este grupo se fracturó cuando se reactivó la lucha guerrillera argentina -la organización Montoneros decidió pasar a la clandestinidad hacia finales de $1975 \mathrm{y}$, se reforzaron las acciones armadas en el Partido Revolucionario de los Trabajadores (PRT) y en el Ejército Revolucionario del Pueblo (ERP)- entre los que la apoyaban y los que no. Se conformaron dos espacios de encuentro para los exiliados, con una identidad política diferente: por un lado se creó en febrero de 1976 el Comité de Solidaridad con el Pueblo Argentino (COSPA) -o llamada "Casa del Pueblo Argentino"- que tenía a la cabeza a Rodolfo Puiggrós (y con militantes de origen universitario, obrero y barrial) y que "se convertiría en la más importante institución del exilio argentino hasta 1979" de carácter montonero, (México fue uno de los lugares de residencia de la máxima conducción de Montoneros hasta que en 1978 se trasladó a Cuba). Por otro lado se encontraba la CAS, constituida formalmente a mediados de 1977 y presidida hasta 1980 por Esteban Rigui y luego por Noé Jitrik, a la cual asistían sectores de izquierda más amplios -socialismo, marxismo, camporismo-, de clase media, autodefinidos como "independientes" e "intelectuales" que privilegiaban las tareas de solidaridad y denuncia por sobre cualquier diferencia política. (Yankelevich, 2009).
} 
clases de historia nacional a hijos de exiliados, se armaron festivales de música y se ofrendaron flores al monumento de San Martín del Paseo de la Reforma en algunas efemérides. En cambio, el Centro de Estudios Argentino-Mexicano de la Comisión Argentina de Solidaridad (CAS) promovido inicialmente por Noé Jitrik, Osvaldo Pedroso y Gregorio Kaminsky focalizó sus intereses en el intercambio y el cruce cultural "bregando, como lo señaló Jitrik, por 'vivir la experiencia mexicana'” (2009, p. 162), organizando ciclos de conferencias en torno a la literatura contemporánea, el psicoanálisis, el feminismo y la crisis del marxismo, y una feria del libro argentina con la producción editorial de los argentinos exiliados ${ }^{22}$.

Tener en cuenta este tipo de diferencias, tensiones o polaridades entre los mexicanos y los argentinos nos ayudará a comprender un poco más que significa el "ser argenmex". Nos preguntamos, entonces, qué parte de lo argentino entra en el prefijo "argen" y qué parte de lo mexicano entra en el sufijo "mex", es decir, qué tensiones o contradicciones son dejadas de lado, minimizadas o silenciadas, cuando padres e hijos/as se identifican como argenmex.

\section{Argentinos y mexicanos, y argenmex: conflictos e idilios}

El término argenmex aparece en un primer momento cristalizado en la novela "El cielo con las manos", publicada en 1981, de Mempo Giardinelli. Posteriormente, junto con Jorge Luis Bernetti, el autor afirma: "ser argenmex es hoy toda una identificación para los exiliados que regresaron. Quizás esa seña de identidad, esa marca de nuestra piel, sea la mejor demostración de que el paso por México tuvo un significado profundo." (2003, p. 159). Se destaca, en estas palabras, a lo argenmex como experiencia vivida, como huella corporal de la situación atravesada, es decir, no sólo como respuesta a una necesidad del exilio, sino, también, como una apuesta de reconvertir esa necesidad en una experiencia positiva, productiva y creadora. En este sentido, veremos cómo esta vivencia es diferente en el caso de los padres e hijos/as de exiliados y analizaremos, también, qué cuestiones deja adentro y qué deja afuera esta compleja fórmula identitaria.

\footnotetext{
${ }^{22}$ A su vez, la CAS generó una revista, Controversia para el examen de la Realidad Argentina, que "trascendió el carácter 'denuncialista' de las publicaciones en el destierro" generando una "crítica y autocrítica en torno a visiones muchas veces dogmáticas presentes en anchas zonas del debate político de la izquierda argentina" (Yankelevich, 2009, p. 167). La revista se organizó en tres ejes temáticos: la derrota -con una crítica fuerte de la experiencia guerrillera, debate iniciado por Schmucler-, el análisis de la situación política, social, económica y educativa de Argentina, y la democracia y sus problemas.
} 
El término comenzó a escucharse tempranamente entre los exiliados argentinos en México. Pablo Yankelevich (2009) plantea, citando a Nora Robotnikof, que quizás la generación de los "verdaderos argenmex" es aquella que conforman los hijos que llegaron con sus padres o que nacieron en México, los que fueron construyendo la historia y la cultura argentina a través de las costumbres de sus padres -influenciados, a su vez, por el sentimiento de deseo del retorno a su país de origen ${ }^{23}$-, que conocieron a su familia extendida y los lugares y paisajes por medio de relatos y fotografías, y que, asimismo, vivenciaron la cultura mexicana en los espacios de socialización como el jardín y la escuela: "Los que vivieron el exilio de rebote y México de primera mano" (2009, p. 340).

La generación de los hijos cumplió un rol fundamental en la incorporación de la cultura mexicana a sus padres, ellos fueron los mediadores ya que facilitaron el ingreso de los padres en "lo mexicano", tal como se advierte en la cita de Carlos Ulanovsky: "gracias a ellas [sus hijas] (...) entendí la esencia de eso que nos modificó para siempre, la cultura que cruzó y sumó lo argentino y lo mexicano.” (2009, pp. 332, 333). En este sentido, los hijos/as juegan un rol fundamental en esta cara del exilio, en tanto experiencia productiva y transformadora. Ellos, siendo niños, han absorbido las costumbres mexicanas de forma más espontánea, menos prejuiciosa, y han trasmitido esas marcas en el seno familiar, posibilitando una mayor apertura de sus padres con el afuera y permitiendo que el exilio se transforme en un espacio positivo, como afirma en el título de su libro Carlos Ulanovsky (2011): "Seamos felices mientras estemos aquí" 24.

A su vez, aparece la idea de lo argenmex como una construcción identitaria configurada no solo en el exilio de los argentinos en México, sino también en el regreso. Esta identificación se desarrolló en mayor medida entre la comunidad de exiliados que retornaron a la Argentina con la democracia, como una forma de reconocerse en aquella experiencia compartida, donde lo mexicano dejó una impronta fuerte (muchos exiliados

\footnotetext{
${ }^{23}$ Soledad Lastra profundiza en su artículo (2013) la idea de transitoriedad de la experiencia exiliar, de un vivir entre paréntesis, un estar de paso: "En la expectativa por regresar se construyó la experiencia del exilio en la cual los migrantes políticos intentaron vivir cotidianamente en el país de asilo pero manteniendo cada día el deseo de volver" (p. 328). A su vez, resalta la idea de la espera: “(...) la espera surge como el sentido que organiza al marco, la clave en torno a la cual giró el día a día vivido en México; espera que se tradujo en nostalgia y en una dimensión de debate político pero que, a modo de un centro gravitacional, pudo articular la experiencia del destierro en base a un sentido depositado en el futuro. El regreso del exilio emerge en el imaginario como el camino a desandar para volver a incorporarse a la vida tal y como era antes de partir. Regresar al país de origen, significaría entonces volver al viejo marco de experiencias que estos exiliados construyeron antes de salir." (p. 333).

${ }^{24}$ Cfr.: "Para mí el "Seamos felices mientras estemos aquí" es una especie de pudoroso altar que contiene secretas claves de supervivencia y de amor" (Ulanovsky, 2011, p. 12).
} 
llegaron a la Argentina con hijos mexicanizados o mexicanos, con costumbres y artesanías mexicanas). Fue, a su vez, una de red de contención entre ellos frente a las difíciles condiciones -tanto laborales, institucionales como afectivas, de sentimientos de "sospecha", etc.- que tuvieron que enfrentar en el retorno ${ }^{25}$ (Yankelevich, 2009). En este caso, también fue diferente el caso de los hijos/as que el de los padres, ya que, para ellos, en su mayoría mexicanizados, fue un desarraigo muy fuerte dejar México e ir a vivir a Argentina. Para ellos no representaba un "volver" o "desexilio" -como a sus padres- sino una separación de sus amistades, sus lugares, sus costumbres, etc.

A partir de estas características, nos interesa puntualizar en las dos marcas generacionales, con sus zonas grises, para entender la identidad argenmex -siempre teniendo en cuenta que cada caso personal, familiar, adopta sus propias formas.

Por un lado, entonces, se encuentra la generación adulta exiliada políticamente que ha sufrido en forma directa las violaciones de los derechos humanos de la última dictadura cívico-militar y su periodo previo -tanto las distintas formas de represión, tortura, prohibición de la libertad como el exilio político- y que se autoidentifica como argenmex desde un lugar de empatía afectiva hacia lo mexicano. También habría que pensar en qué medida esta construcción identitaria se relaciona con las casas del exilio: se podría pensar que hay una identificación mayor del ser argenmex en relación a la CAS, debido, en parte, al perfil político e intelectual de la misma -sus integrantes eran sectores de izquierda más amplios, autodefinidos como "independientes" e "intelectuales". Una vez retornada al país de origen, esta construcción identitaria se tradujo en una forma melancólica o nostálgica por el alejamiento ahora de México ${ }^{26}$. También, se puede incluir cierto grado de construcción mítica e idealizada depositada en el papel que tuvo México como país refugio para los argentinos.

\footnotetext{
${ }^{25}$ La línea divisoria que se formó entre "los de adentro y los de afuera" exhibe, para Yankelevich (2009), dos sentidos: por un lado los que se quedaron en la Argentina fueron tildados de "cómplices" de la dictadura (para los de afuera), y los que se fueron como voceros de la "subversión" (para los de dentro). Pero por otro lado cuando los desterrados regresaron a la Argentina tuvieron que "enfrentar sus años pasados en el exilio como un estigma que condenó a "los que se fueron" a ser considerados auténticos privilegiados por no haber tenido que soportar la oprobiosa atmósfera dictatorial." Para profundizar en las diferentes problemáticas sobre el retorno de los exiliados se puede consultar la tesis de doctorado en historia de la Universidad Nacional de La Plata de Soledad Lastra (2014), Los retornos del exilio en Argentina y Uruguay. Una historia comparada de las politicas y tensiones en la recepción y asistencia en las posdictaduras (1983-1989).Ver, también, Jensen, Silvina (2008) “¿Por qué sigue siendo políticamente incorrecto hablar de exilio? La dificultosa inscripción del exilio en las memorias del pasado reciente argentino (1983-2007)".

${ }^{26}$ Soledad Lastra afirma que este apelativo de argenmex les sirvió a los exiliados enfrentar las incertidumbres de los primeros tiempos del retorno: "El extrañamiento frente a un país que se mostraba indiferente, pudo haber sido atenuado entonces con la persistencia de ciertas costumbres y significados adquiridos en México; por lo menos hasta que la vida cotidiana se reorganizara en una nueva epojé natural." (2013, p. 342).
} 
Por otro lado se encuentra la generación de los/as hijos/as ${ }^{27}$ de esos padres, que vivieron el trauma desde una trasmisión de la memoria afectiva familiar -sin haber vivido los hechos directamente o habiéndolos presenciado en una temprana edad-, pero que "mamaron" de manera profunda tanto la cultura argentina -desde el núcleo familiar- como la cultura mexicana -en el jardín de infantes, la escuela y espacios de sociabilización por fuera del seno familiar- por lo cual se conformaron en una identidad híbrida, difícil de anclar en un sólo territorio, a un estado-nación. Retomo este concepto teorizado por -el argenmex- García Canclini (1992) en tanto permite analizar los distintos tipos de cruces interculturales sin olvidar sus tensiones conflictivas -tanto el término "mestizaje", relacionado con el tipo de mezcla étnica; como "sincretismo", referido a fusiones religiosas o movimientos simbólicos tradicionales, nos limitan teóricamente al abordar este proceso de cruce identitario entre argentinos y mexicanos $^{28}$.

De este modo la identificación con lo argenmex va variando en los distintos casos, exhibiendo diferentes apropiaciones y usos por parte de los argentinos. Para muchos, la fórmula argenmex denota la contracara positiva del exilio asociada con la "salvación", "libertad" y “enriquecimiento", constituyendo, entonces, una paradoja del exilio: "Por una parte, implica pérdida, condena, castigo, fractura. Por otra, salvación, libertad, enriquecimiento. Si el exilio es trauma y hasta la muerte misma (Ovidio), no es menos cierto que es la vida (Víctor Hugo) o cuanto menos una forma de eludir la muerte." (Jensen, 2011, p. 3).

Esta paradoja resulta clave a la hora de analizar a los actores y a sus producciones culturales: hay que tener en cuenta que, en un mismo proceso, conviven los factores negativos y positivos de la experiencia exiliar. Si bien lo argenmex connota esta contracara positiva del exilio, sin embargo aparecen también ciertas tensiones y conflictividades al interior de la construcción identitaria.

\footnotetext{
${ }^{27}$ En esta "generación de hijos" se hace referencia principalmente a aquellos que han experimentado una parte de su infancia en México. Hay, también, otros casos de hijos de exiliados que han vivido muy poco tiempo en tierras mexicanas pero que aun así el exilio fue muy significativo y operó de distintas formas en sus vidas.

${ }^{28}$ Es curioso notar que García Canclini explicita en el prefacio a la edición argentina de Culturas híbridas que su propia historia de vida y su construcción identitaria argenmex fueron indispensables para reflexionar sobre los procesos de cruces interculturales: "Fuimos admitiendo, entonces, que estudiar la cultura es ocuparse de las mezclas. Estoy entre los que necesitamos convertirnos en migrantes para incorporar estos descubrimientos, modularlos en una mirada diferente sobre lo social y en un estilo de trabajo. Ser "argenmex" me sirvió para entender tanto la miopía de los liberales sarmientinos que absolutizaron lo europeo, como la de los populismos que aún persiguen, contra aquellos liberales, un ser nacional igualmente improbable." (1992, p. 12).
} 


\section{“Y a mí qué me importa?” o "El que se enoja, pierde”}

La pregunta que nos surge, entonces, con respecto a la relación compleja entre argentinos y mexicanos podría ser: ¿cuáles son aquellos factores que intervienen en los vínculos entre ambas culturas, aquellos elementos que interfieren con su diferencia el “idilio” de la unión armoniosa argenmex? Néstor García Canclini (1998) delinea ciertas cuestiones que tienen que ver con las diferencias culturales - que a veces provocan una mirada negativa- entre argentinos y mexicanos, destacando especialmente dos de carácter estructural: la relación con la historia y sus diferencias étnico-nacionales, y la manera de gestionar la relación de poder.

En relación a la diferente forma de abordar el pasado histórico y las raíces étnico-nacionales entre ambas culturas, García Canclini expone que en la Argentina hay, por un lado, una poca valorización de las tradiciones y del patrimonio histórico, y una preocupación siempre por el porvenir antes que por el pasado; y, por el otro, un hábito de tratar de olvidar la conformación multiétnica de la sociedad argentina y de sus diversas regiones -Buenos Aires/Noroeste Argentino/Patagonia, etc. En este sentido, los argentinos exiliados políticos que fueron a vivir a México, en contraste con la relación reacia existente en Argentina con la historia, se sintieron en México "sorprendidos y fascinados por la densidad de monumentos preservados y de tradiciones vivas, museos que requirieron altas inversiones y arcaicas fiestas campesinas que se repiten también en las ciudades.” (1998, pp. 59, 60). Además, y en relación a las raíces étnico-nacionales "desiertas" para la mirada de muchos argentinos, México fue el lugar donde encontraron “el rostro indígena de América Latina.” (p. 60).

García Canclini, desde el lugar de exiliado político argentino, se pregunta por la mirada negativa y el rechazo (en forma de bromas, chistes críticos ${ }^{29}$ ) que generan los argentinos en México, asociados con actitudes soberbias y presuntuosas. La relación diferente con la historia no llega a explicar dicha mirada -ya sea porque en el caso de los uruguayos y los chilenos se podría tener la misma percepción de distancia intercultural, y sin embargo no existe la misma mirada crítica, y porque esta caracterización de los argentinos es compartida por otros países. Por un lado, esta actitud de los argentinos se puede asociar - a partir de un estudio realizado por Orlando

\footnotetext{
${ }^{29}$ Algunos de los chistes y bromas son "los argentinos son como italianos que hablan español y se creen ingleses" o "el ego es el pequeño argentino que todos llevamos dentro" (García Canclini, 1998).
} 
D'Adamo y Virginia Garcia Beadoux que cita el autor- a una conciencia de "poderío" y "superioridad" alimentada por la importancia del aporte extranjero en Argentina y las características económicas y socioculturales favorables a fines de siglo XIX y principios del XX. Quedaría sin explicar por qué se sostiene esa imagen aun cuando la Argentina entra en decadencia económica en la segunda mitad de siglo XX. Por otro lado, García Canclini se refiere al excesivo énfasis del habla argentina, en el sentido en que somos gritones, hablamos todos al mismo tiempo y cuando pedimos algo pareciera que estamos dando órdenes. Entonces, los mexicanos nos preguntan: “¿Por qué estás enojado?" Este rasgo se opone al carácter "reservado, silencioso y melancólico" de ellos. Analía Miller y Violeta Burkart Noe, en su tesina "Argenmex, exiliados hijos", abordan también estas tensiones culturales que se dan a partir de los puestos de trabajo y lugares académicos que ocuparon los argentinos en México, generando una mirada negativa por parte de los mexicanos, con calificativos como: "prepotentes, engreídos, jactanciosos, chantas" 30 .

Para un contraste más pronunciado, García Canclini compara las frases claves respectivas de cada cultura: en la Argentina sería “¿Y a mí qué me importa?”31 y en México podría ser "El que se enoja, pierde." Estas diferentes frases claves y formas de expresión tendrían un anclaje más profundo -relacionado con el orden colectivo en el caso mexicano y con la satisfacción individual en el caso argentino- en las culturas políticas de ambos países y los modos de hacer política. Mientras en México existe una tendencia a ritualizar los conflictos y las diferencias y a reproducir los modelos estables y pacíficos de la sociedad, en cambio en Argentina domina el vínculo interpersonal directo, la burla a las instituciones y la forma poco ceremonial de interacción. Es necesario aclarar que si bien hablamos de "argentinos", los exiliados políticos pertenecen a un grupo particular de argentinos con costumbres y formas de comunicación propia de la capital del país -y dentro de un círculo de profesionales académicos e intelectuales pertenecientes a sectores medios.

Habría que pensar, entonces, qué queda dentro y qué queda afuera en los usos de la construcción argenmex. Si pensamos en esta identidad para la generación de padres,

\footnotetext{
${ }^{30}$ Cfr.: "Además de acostumbrarse a México, debían lograr que los mexicanos se habituaran a la "invasión" de argentinos que hubo en esos años. Son mínimas las referencias, pero ha habido celos de parte de mexicanos por los puestos laborales y académicos que fácilmente fueron abiertos a los argentinos. Además de la solidaridad manifiesta, también hubo desconfianza, rechazo y los inevitables chistes sobre argentinos, dada la fama mundialmente ganada por la idiosincrasia nacional. La visión mexicana de los argentinos era casi siempre grotesca y brutal: prepotentes, engreídos, fanfarrones, jactanciosos, chantas." (Analía Miller y Violeta Burkart Noe, 2007, p. 25).

${ }_{31}$ García Canclini (1998) cita la frase “'Y a mí qué me importa?” analizada por Guillermo O’ Donnell.
} 
se la podría asociar más con un uso posterior, ya de regreso al país de origen, relacionado con la melancolía y la idealización del país de refugio en algunos casos, y, en otros, se trata de darle un nombre y un valor positivo a la experiencia vivida en México, un modo de renombrar la pérdida que todo exilio supone una vía para pasar (y sumar) de la condición de exiliado a la de argenmex ${ }^{32}$. Esto coloca en un segundo plano los choques culturales analizados, lo que implica desdibujar la zonas más conflictivas de fricción entre ambas identidades proyectando en este sentido una "armonía" cultural e identitaria como modo de suturar las heridas y pérdidas marcadas por el exilio.

Y, si pensamos en la generación de hijos, los usos de esta construcción estarían más ligados a elaborar un lugar entre dos identidades correspondientes a estadosnaciones, a darle un nombre al sentimiento identitario dual, híbrido, y reconvertir y/o superar la sensación de ser "Sapo de otro pozo".

\section{“Pero qué país te gusta más?"}

Como mencionamos anteriormente, la generación de hijos de exiliados se formó en distintos ámbitos (núcleo familiar, el jardín de infantes, la escuela y distintos espacios de sociabilización) que pertenecían a dos culturas: la mexicana y la argentina. Esta dualidad, generó en muchos, por un lado una identidad híbrida, cuya hibridez no termina por formar una estructura definida, sólida, asentada, en donde las partes encastren en una mera totalidad, sino una hibridez ambivalente que va de una a otra pertenencia, una identidad inestable, difícil de contener en un sólo territorio; y por otro lado, como contracara, la necesidad de pertenencia a algo en qué poder aferrarse.

En el audiovisual "Argenmex", realizado por Analía Miller y Violeta Burkart Noe (2007), distintos hijos de exiliados manifiestan esta doble identidad argentina y mexicana en frases como "En México me decían argentina y al llegar a Argentina me llamaban mexicana", "Venimos a Argentina pero no dejamos de ser mexicanos. Nosotros somos de los dos países. No se nos puede vincular a uno solo", "Esa sensación de nostalgia, de estar siempre incompletos, que es lo que nos constituye, es el precio que pagamos.”, “A mí se me dificulta ser mexicana cuando ya soy argentina”, "Como sapo

\footnotetext{
${ }^{32}$ Cfr.: "Los exilios son, a veces, ocasiones en que un destino impuesto puede dejar de ser una fatalidad: si uno se deja instruir por lo diferente, puede así expandir lo propio y contribuir a que el lugar de origen y el nuevo se comuniquen. Pasar de lo ritual a lo virtual. Creo que los exilios del Cono Sur y de otros países en México no han sido una fatalidad inútil en tanto lograron hacer algo productivo con lo involuntario." (García Canclini, 1998, p. 72).
} 
de otro pozo, no somos mexicanos en México, ni argentinos en Argentina. Somos eso, somos argenmex". Estas frases se suman a otros testimonios que también plantean esta sensación de ser "el otro", el "bicho raro", como por ejemplo "Nuestras vidas han estado signadas por ello: siempre fuimos la persona extraña, la que no encaja." (Carta abierta de Hijos e hijas de exiliados, 2006, s/p. $)^{33}$ o, como plantea Tomás Alzogaray en el dibujo que incluimos al inicio de esta tesis “¿pero qué país te gusta más?”.

Ante la pregunta ¿quién soy o cómo quiero ser?, muchos hijos de exiliados han tenido la necesidad de re-plantearse la construcción de su identidad, es decir, cómo se representan, son representados o podrían representarse. En este sentido -y siguiendo las reflexiones de Leonor Arfuch- se da una narrativización de la identidad: "No hay entonces identidad por fuera de la representación, es decir de la narrativización necesariamente ficcional- del sí mismo, individual o colectivo" (2005, p. 24). A su vez, Elizabeth Jelin (2012) plantea el constante vaivén de "mutua constitución" entre la memoria narrativa y la identidad. Para establecer ciertos parámetros de una identidad, la persona selecciona memorias que la relacionan con "otros" $\mathrm{y}$, entonces: "estos parámetros, que implican al mismo tiempo resaltar algunos rasgos de identificación con "otros/as" para definir los límites de la identidad, se convierten en marcos sociales para encuadrar las memorias." (p. 58). Si bien a esta construcción identitaria se le puede encontrar un carácter un tanto utópico o irreal (en el sentido en que, pertenecer a una nacionalidad proyectada y una territorialidad inexistente y binacional se hace difícil en el mundo físico), no hay que estancarse en los conceptos dicotómicos excluyentesreal/irreal; verdad/ficción-, sino ver que la combinación de estos aspectos, posibilitan la proyección de un lugar simbólico, identitario y, por lo tanto, existente.

Es, entonces, con esta figura identitaria argenmex que muchos hijos/as de exiliados argentinos en México logran anclar su pertenencia, su identidad. Este es además uno de los usos positivos que se le otorga a la fórmula identitaria, y que desdibuja las tensiones antes mencionadas ${ }^{34}$. Profundizaremos, entonces, en este uso

${ }^{33}$ Cfr.: "El exilio partió en dos nuestras vidas: somos argentinos, pero también de México, España, Venezuela, Italia, Brasil, Holanda, Suecia, Francia, Nicaragua (...) Y esto nos dificulta echar raíces. En diferentes momentos de nuestra vida algunos nos sentimos o decidimos finalmente "ser argentinos". Otros nos quedamos en los países que nos refugiaron. Y algunos más, aun continuamos buscando un lugar de pertenencia. Todos transitamos en mayor o en menor medida la condición de ser "el otro", el "bicho raro". Crecimos en los países que nos albergaron sintiéndonos diferentes. Quienes regresamos a la Argentina continuamos siendo "el otro".

Nuestras vidas han estado signadas por ello: siempre fuimos la persona extraña, la que no encaja." (Hijas e Hijos del Exilio, 2006, s/p.).

${ }^{34}$ Según Soledad Lastra -a partir de unos aportes que hizo a una ponencia mía- habría que pensar, además del uso positivo, del uso estratégico que supone el identificarse como argenmex en la actualidad: dentro 
que hace la segunda generación y que la diferencia -junto con otros aspectos- de la de sus padres.

\section{La segunda generación y sus problemáticas}

Desde temprano los hijos de exiliados comenzaron a vincularse entre sí, a establecer redes a través de reuniones, en la formación de grupos, en actividades en conjunto. Una de las organizaciones que se destacó dentro de los exiliados en México fue la Juventud Argentina en el Exilio (JAE), conformada en 1981 con la participación de varios adolescentes/jóvenes hijos de exiliados, presos o desaparecidos, entre ellos Magdalena Jitrik, Fabián Cerejeido, María Inés Roqué, Pablo Funes, Julián Gadano, Francisco Ferreira, Martín Levenson, Isabel y María Maldonado, Santiago Pérez, Ana Tamarit, Mariana y Pablo Calvo, Federico Bonasso, Laura Rey y Paola Stefani. Ello les permitió ir recortando un espacio propio, el de los hijos, respecto a sus padres. Un espacio que los diferenciaba, en primera instancia, por sus preguntas moldeadas de acuerdo a sus intereses generacionales. Nos resulta importante destacar que incluso desde la misma nominación elegida, "juventud" en lugar de "hijos", se establece la distancia con sus padres. Yankelevich (2009) expone, a partir del "Cuaderno de reuniones plenarias de la JAE" y del texto "A la juventud argentina y a todos los jóvenes" brevemente los dos pilares en que se basó la JAE. El primero, de carácter generacional, afirma la identidad juvenil ${ }^{35}$, ya que se separan de las organizaciones del exilio argentino en México creadas y dirigidas por los adultos. Y el segundo, de carácter político, defiende una posición independiente, como ellos mismo afirman: “(...) no vamos a depender de ninguna organización ya formada, ni de grupo, ni de partido, así como tampoco actuaremos en representación de ninguno". (2009, p. 179).

A su vez, en un momento posterior e instalados en Argentina, algunos hijas/os de exiliados, de presos o de "desparecidos" comienzan a integrar las distintas organizaciones políticas: HIJOS-México (Hijos por la Identidad y la Justicia contra el

de los hijos se ha creado una suerte de comunidad por compartir códigos culturales argenmex, estableciendo una distancia con los hijos de exiliados de otros países. Habría que pensar si esto se relaciona con cierto "prestigio" o reconocimiento que tienen los argenmex en las actividades que realizan o en la esfera pública -y, en este sentido, pensar también, cuál es el prestigio "heredado" de sus padres.

${ }^{35}$ Una de las acciones de la JAE fue establecer una correspondencia desde 1982 con los combatientes de la Guerra de Malvinas, como cita Yankelevich de la JAE: "Creemos que en la medida que más nos comuniquemos con grupos de jóvenes en Argentina, sabremos mejor cómo colaborar con ellos. Por esto nos dirigimos a ustedes, tenemos gran interés de extender información sobre su causa a nivel internacional (...)" (2009, p. 180). 
Olvido y el Silencio), H.I.J.O.S. capital (Hijos e Hijas por la Identidad y la Justicia contra el Olvido y el Silencio) o las organizaciones de H.I.J.O.S regionales dentro y fuera de Argentina. Se conforma, en el 2006, la agrupación Hijas e Hijos del Exilio a raíz de una reunión convocada por la Comisión de Ex Exiliados Políticos de la República Argentina (COEPRA) en el auditorio del Hotel Bauen en la Ciudad Autónoma de Buenos Aires -en el marco de la semana del exilio y del Día del Refugiado Político. Luego de unas reuniones, las Hijas e Hijos del Exilio publican una carta abierta - con forma de convocatoria- dirigida a toda la comunidad, en donde aparecen cuestiones interesantes a lo largo de todo el texto, seleccionadas y citadas a continuación:

(...) Desde pequeños nos convertimos en víctimas de la violenta represión que azotó a nuestro país. El exilio político que nos tocó vivir es una violación a los Derechos Humanos.

(...) Ha habido peores atrocidades que el exilio, como las desapariciones de personas, las torturas, los secuestros clandestinos y las apropiaciones de niños. Esos delitos los sentimos como si nos hubiesen pasado a nosotros, en muchos casos también nos sucedieron. Por respeto, de nuestra parte ha habido silencios. (...) Pero esos silencios y omisiones no borran las heridas. Ellas están, persisten y han crecido en estos años.

(...) Sentimos que ya no éramos ese "bicho raro", apodo con el que durante años convivimos. Nos encontramos con otr@s que pasaron por la misma experiencia, que tenían conflictos con ello. Conflictos como la doble identidad que todos albergamos, la argentina y la de los países que nos refugiaron, en los cuales crecimos y/o nacimos; la dualidad identitaria, que nos dificultó echar raíces. (...) El exilio nos dividió, nos partió al medio. Somos argentinos, pero también mexicanos, españoles, nicaragüenses, ecuatorianos, italianos, holandeses, brasileños, etc... ¿Cuál es nuestra identidad? ¿Cuál es nuestro lugar en el mundo? ¿Qué código cultural manejamos? En muchos casos somos apátridas, extranjeros, sin nacionalidad, sin una situación jurídica clara tan siquiera.

(...) El exilio de nuestros padres luego se convirtió en nuestro exilio, en nuestro desarraigo, porque cuando ellos "volvieron", nosotros "nos fuimos". (...) Nuestra socialización primaria no ha sido en la Argentina, sino en otros países. Nos robaron ese derecho y a pesar del afecto que sentimos por los países que nos refugiaron, era aquí donde tendría que haber ocurrido. $Y$ vinimos a la Argentina y tuvimos que volver a adaptarnos. 
(...) Y dentro del exilio, hay diferencia entre los adultos y los niños, unos y otros sufren, pero los primeros comprenden lo que ocurre, a diferencia de los segundos.

(...) Se trataba de hombres y mujeres (...) que nos enseñaron valores e ideas donde lo esencial era un proyecto de país nuevo basado en la justicia, el amor y el respeto por los otros. Esos ideales han sido la herencia de nuestros padres. El dolor, la dualidad, la sensación de no pertenencia, el desgarro: la herencia de la dictadura militar.

(...) Creemos que no fue casualidad que muchos de nosotros eligiéramos transitar por el camino de las artes y las humanidades. No sólo nos identificamos en nuestra experiencia pasada, sino también en quienes somos ahora, 30 años después. Somos parte de un sueño, llenos de memoria, esperanzas y proyectos.

(...) Recientemente los hij@s del exilio comenzamos a reunirnos, primeramente para compartir esos huecos colectivos que no podíamos compartir con la gente de nuestra generación, y con la intención de formar un espacio propio, sabemos que en grupo podremos concretar nuestros sueños de un país justo, solidario, con libertad y en democracia. Invitamos a otros hij@s de exiliados y a quienes se sientan parte de estos ideales y quieran participar conjuntamente con nosotros.

Contacto: hijosdelexilio@yahoo.com.ar. (Agrupación Hijas e Hijos del Exilio, 2006, s/p.).

Teniendo en cuenta que en esta carta se reúnen hijos/as que han sufrido el exilio en distintos países refugio, resulta interesante ver cuáles son los distanciamientos/diferencias que se plantean con respecto a la generación de los padres y cuáles son sus herencias.

En primer lugar, la representación de víctima de la violencia de estado y sus consecuencias traumáticas $^{36}$-en algunos vivenciadas desde pequeños y en otras heredadas en el núcleo familiar-, así como los silencios $^{37}$, son parte de las historias compartidas por ambas generaciones, aunque vividas de distinta manera, especialmente en la experiencia directa o trasmitida de los hechos; en la diferencia del grado de comprensión entre un adulto y un niño, y en el particular desplazamiento que los hijos

\footnotetext{
${ }^{36}$ Recordemos que en ningún caso de los artistas abordados en la presente tesis, el padre o la madre se encuentran desaparecidos, pero si muchos de ellos tienen algún tío/tía o familiar cercano desaparecido ${ }^{37}$ Cabe aclarar que con respecto a los "silencios" por parte de los hijos, si bien ellos aclaran que se deben por "respeto" a los desaparecidos, entran en juego las presiones preexistentes en el ámbito de la generación adulta con respecto al debate ya planteado entre "los de adentro y los de afuera" y el contexto de reapertura democrática a fines de 1983 poco dispuesto a escuchar las voces de los exiliados o a brindar algún tipo de ayuda estatal de tipo político, social o económico.
} 
llevan a cabo desde el lugar de la víctima como un lugar pasivo hacia una postura activa. En esta carta aparece una transformación en el relato de los hijos que va desde la caracterización del hijo del exiliado como víctima pasiva al rol del hijo como víctima política, sujeto activo y colectivo. Lo que también implica un desplazamiento desde el ámbito privado de la institución familiar hacia el espacio público de la institución política por un lado o, por el otro, hacia el mundo de las artes y la productividad artística.

En segundo lugar, en la carta abierta los hijos plantean explícitamente ciertos distanciamientos con respecto a la generación adulta, como por ejemplo, la estigmatización de "bicho raro" a la que ya nos referimos. Teniendo en cuenta que los hijos, a diferencia de sus padres, han tenido una dualidad identitaria y en formación, se acentúa ese sentimiento de estar siempre en otro lugar, de ser el extranjero (tanto en México como en Argentina). A esto se suma la gran exigencia de los hijos de conectar lo argentino con lo mexicano en su etapa de formación y de socialización. Eran mediadores, portadores de las costumbres mexicanas vivenciadas en el jardín o en la escuela, llevadas al interior de la familia argentina y viceversa. En su artículo sobre los niños del exilio en México, Susana Sosensky destaca ciertos temas que se repiten en los testimonios: "el papel de los niños como transmisores de memoria, como guardianes de la seguridad familiar, como portadores de códigos, costumbres y tradiciones mexicanas dentro de las familias argentinas exiliadas en México.” (2008, s/p.).

Otro dilema que se les presentó luego fue la vuelta de sus padres al país de origen. Este hecho fue claramente vivenciado de manera diferente, mientras que para los mayores era una suerte de "regreso", para los menores era un "desarraigo", una partida involuntaria, una suerte de "nuevo exilio" "38, un esfuerzo nuevamente de insertarse en un grupo, en las costumbres argentinas (no olvidemos que los hijos estaban mucho más

\footnotetext{
${ }^{38}$ Carlos Ulanovsky cuenta la experiencia del retorno del exilio: "Allí estaban mis dos hijas que mejor que nadie podían dar fe de este tiempo de incorporaciones ricas, distintas, contradictorias, de crecimiento. Inés, la menor, riéndose junto con su amiga Flor, una mexicana de verdad, pero argenmex de corazón, dándose cuenta que eso de ver moquear a los mayores provoca siempre una inquietud desconocida. Inés jugaba a uno de sus pasatiempos preferidos: imitar la forma de hablar de los argentinos. Julieta, la mayor, literalmente destrozada, llorando el desconsuelo adolescente de la despedida, abrazando, sin poder desprenderse, tironeada por su doble lealtad, prometiendo y demandando cartas. Creo que mis hijas fueron realmente felices en México y eso, además de parecerme admirable, me hace sentir feliz a mí." (2011, p. 19). Para consultar más sobre las problemáticas sobre el retorno en el caso de la segunda generación, ver los textos de Costa Adano (2002) El retorno del exilio y la integración al Uruguay postdictatorial en la perspectiva de la segunda generación. Continuidades y rupturas entre generaciones; Aruj y González (2008) El retorno de los hijos del exilio. Una nueva comunidad de inmigrantes o, de los mismos autores, "Los hijos del exilio" (2005), y Dutrénit Bielous (2013) "Dictadura y exilio en la narrativa de los hijos".
} 
"mexicanizados" que los padres), de generar lazos identitarios con el país que muchas veces representaba el lugar de las "desapariciones" y la muerte y/o la utopía de los padres. Además la apertura democrática a fines de 1983 no generó un apoyo estatal político, social o económico a los exiliados. Antonio Octavio Piccato Rodríguez en su ensayo "Cuando la infancia juega al exilio" presenta el segundo destierro de la siguiente manera:

Faltarían todavía muchas cosas para explicarle a este niño, o para explicarse este niño. Faltaría, por ejemplo, narrar qué tan difícil le resultó volver al país donde nació y sentirse allí más extranjero que en ningún otro lado. Faltaría narrar ese amargo desencuentro que para tantos como él fue motivo de un segundo destierro, el definitivo y final. Faltaría explicarse cómo logró sobrevivir a la identidad del desterrado en tierra propia, como decidió finalmente renunciar a esa tierra; y cómo, en definitiva, frases tan estúpidas como "vos te fuiste y yo me quedé a aguantarme" o "tu familia fue víctima de una guerra" lograron romper el mito de un país y construir, en cambio, un abismo de separación (2007, p. 46).

En tercer lugar, un elemento que aparece como "heredado" de los padres a sus hijos son los ideales políticos, -siempre teniendo en cuenta que los exiliados argentinos fueron expatriados por razones políticas. Sin embargo, éstos han sido moldeados de forma diferente $-\mathrm{y}$ bajo otro contexto. Tanto en la carta abierta como en la JAE se colocan en una postura política de izquierda amplia, sin explicitar partidos políticos específicos o formas de militancia -en la JAE se declaran con "independencia política" y en la carta abierta se habla ampliamente de "sueños de un país justo, solidario, con libertad y en democracia" (para reflexionar más profundamente sobre este distanciamiento habría que analizar también cómo influyeron en los hijos las distintas líneas políticas de las casas del exilio de los padres, el COSPA y la CAS, y la autocrítica de la "derrota" dada dentro de una parte de la izquierda exiliada). Junto con la necesidad de agruparse políticamente, parecería que en los hijos también cobra importancia el agruparse, en el sentido de generar un grupo identitario propio conformado entre sus pares en donde se puedan reconocer.

Por último, en cuarto lugar, aparecen otras dos cuestiones que son interesantes remarcar: el hecho de hacer explícito que la gran mayoría de hijos que firman la carta se dedican a las artes y las humanidades -“no fue casualidad que muchos de nosotros 
eligiéramos transitar por el camino de las artes y las humanidades"- y la forma de convocatoria -con el mail de la agrupación- a través de la carta abierta. Estas son formas de generar lazos afiliativos con el resto de la comunidad, ampliando así la red de la transmisión de la memoria.

Volviendo entonces a lo expresado anteriormente, las particularidades de los hijos de exiliados, tanto su carácter de "hijos" de padres exiliados -víctimas de la última dictadura cívico-militar argentina- como su sentimiento de "bicho raro" y la inestabilidad identitaria producida por el doble destierro, han provocado en esta generación una necesidad explícita de pertenecer a un determinado grupo o reunirse en una actividad que ancle su identidad (aunque esto en muchos casos se perciba como un proceso abierto y en constante cambio). Entonces, este sentimiento se vehiculiza de determinadas formas anteriormente analizadas: la voluntad de convertir al "hijo" pasivo situado dentro de la institución familiar en una forma de sujeto político, activo y colectivo a través del agrupamiento en el mundo de la militancia política (Hijas e Hijos del Exilio, 2006) y/o en el de las artes, y/o en el de los argenmex. También, como se reflexionó anteriormente, tanto la agrupación política -que invita a las personas a participar activamente-, como las producciones estéticas -que generan un diálogo afectivo/intelectual con el espectador- son maneras de comunicar estas vivencias particulares, de elaborar sus traumas, y de establecer lazos afiliativos con la comunidad en general. Es un pasaje de conversión de la pérdida, condena, castigo, fractura en la salvación, libertad, enriquecimiento (Jensen, 2011): “Creemos que no fue casualidad que muchos de nosotros eligiéramos transitar por el camino de las artes y las humanidades. No sólo nos identificamos en nuestra experiencia pasada, sino también en quienes somos ahora, 30 años después. Somos parte de un sueño, llenos de memoria, esperanzas y proyectos". (Hijas e Hijos del Exilio, 2006, s/p.). 


\section{CAPÍTULO 2. MEMORIA, TESTIMONIO, ¿POS?MEMORIA Y ARTE}

Es verdad que hubiera podido matarme o dejarme matar, pero quería sobrevivir, para vengarme y para dar testimonio de todo aquello. No creáis que somos monstruos, somos como vosotros, aunque mucho más desdichados.

Testimonio citado por Primo Levi

(...) De parte de hombres que han conocido esta privación extrema no podemos esperar una declaración en el sentido jurídico del término sino otro tipo de cosa, que está entre el lamento, la blasfemia, la expiación y el intento de justificación, de recuperación de sí mismos. Debe esperarse más bien un desahogo liberador que una verdad con rostro de Medusa.

Primo Levi

\section{La era de la memoria y del testimonio}

Desde la década del 80 se intensificaron a nivel global las prácticas en torno a la memoria a partir, en gran medida, del debate sobre la experiencia de la Shoah, y, en el caso latinoamericano, de las dictaduras del Cono Sur -colocando al siglo XX como la era de guerras, genocidios, totalitarismos y crímenes de lesa humanidad. Esta cultura o boom de la memoria se extiende a lo que Andreas Huyssen (2007) denomina "pretéritos presentes", abarcando otras memorias que son propias de nuestra época: proliferación de museos, moda retro, restauración de viejos centros urbanos, paisajes y pueblos museificados, protección de patrimonio, grabación de historias a través de nuevas tecnologías, escrituras autobiográficas, prácticas fotográficas sobre memorias en artes visuales, documentales, series televisivas, películas, investigaciones, aniversarios, conmemoraciones, monumentos, etc. A su vez, esta cultura de la "memoria total" va acompañada de una producción y exhibición cultural intensa y extensa que supera los ámbitos institucionalizados y se dispersa por todos los medios de comunicación masivos y espacios públicos y privados. Se da una museización en los distintos ámbitos cotidianos, -que por supuesto trasciende las fronteras de la tradicional institución jerarquizada que fue el museo en la modernidad, siendo parte de la cultura visual (Mirzoeff, 2003). Dentro de esta proliferación de prácticas en torno a la memoria, se da 
lo que Enzo Traverso caracteriza como "reificación del pasado", convirtiendo a la memoria en un objeto de consumo "estetizado, neutralizado y rentable" (2007, p. 68).

Es importante distinguir, siguiendo a Tzevan Todorov (2008), qué tipo de memorias aparecen en esta sobreabundancia de información y qué uso se hace de ellas. El autor destaca -en contraposición al uso literal $^{39}$ - el uso ejemplar que se puede lograr con los recuerdos, esto es la capacidad de poder utilizar la memoria recuperada de un hecho singular traumático del pasado en una situación nueva. Transformar un escenario doloroso en un ejemplo o modelo que ayude a interpretar y comparar los hechos con el presente implica una doble operación: por un lado, a nivel individual se neutraliza o margina el dolor personal, como en un trabajo de "duelo"; por el otro lado, al abrir ese recuerdo a la "analogía y a la generalización", se construye un exemplum y con ello se extrae una lección que incumbe ya a la esfera pública y no sólo a la privada. En este sentido, se logra superar esa instancia de conmemoración obsesiva del pasado, esa sobreabundancia de información o abuso de la memoria, para poder reflexionar sobre otros hechos y otros actores -logrando separarse del yo y pensar en el otro. La pregunta sobre el recuerdo traumático se focaliza, entonces, no tanto en el pasado, sino en la proyección de ese pasado hacia el presente y futuro: “¿para qué puede servir, y con qué fin?" (p. 56).

En correspondencia con la reflexión de Todorov, Elizabeth Jelin (2012) plantea que no sólo las víctimas directas, sino también los observadores y testigos secundarios pueden tener una fijación con un hecho traumático del pasado, sin lograr una distancia que evite la compulsión a la repetición y la identificación con las víctimas, es decir sin lograr una separación con el objeto perdido. En este sentido ella alerta sobre un doble peligro: el de un "exceso de pasado" que se advierte en la repetición ritualizada y compulsiva, y el de un "olvido selectivo" que puede ser instrumentalizado y manipulado. Para correrse de esos dos riesgos, la autora propone "trabajar", "elaborar" las memorias traumáticas en lugar de repetirlas y actuarlas constantemente. Desde la teoría psicoanalítica y siguiendo los estudios de Sigmund Freud, Dominick LaCapra y Paul Ricœur, entre otros, Jelin retoma, entonces, el concepto de "trabajo colaborativo"

\footnotetext{
${ }^{39}$ En este caso: “(...) Ese suceso -supongamos que un segmento doloroso de mi pasado o del grupo al que pertenezco- es preservado en su literalidad (lo que no significa su verdad), permaneciendo intransitivo y no conduciendo más allá de sí mismo. En tal caso, las asociaciones que se implantan sobre él se sitúan en directa contigüidad: subrayo las causas y las consecuencias de ese acto, descubro a todas las personas que puedan estar vinculadas al autor inicial de mi sufrimiento y las acoso a su vez, estableciendo además una continuidad entre el ser que fui y el que soy ahora, o el pasado y el presente de mi pueblo, y extiendo las consecuencias del trauma inicial a todos los instantes de la existencia." (Todorov, 2008, pp. 49, 50).
} 
(working-through) para pensarlo en un plano más político y colectivo: "En el plano colectivo, entonces, el desafío es superar las repeticiones, superar los olvidos y los abusos políticos, tomar distancia y al mismo tiempo promover el debate y la reflexión activa sobre ese pasado y su sentido para el presente/futuro." (p. 50). Jelin apuesta al acto de retomar el pasado para reflexionar sobre el presente, teniendo el futuro como horizonte, lo que implica un arduo trabajo para el sujeto. Así, las perspectivas de Todorov y Jelin acá citadas procuran escapar a los diversos modos de reificación de las memorias, insistiendo en el trabajo reflexivo sobras las mismas, e invitan a pensar en "la relación entre memoria y política, y entre memoria y justicia.” (Jelin, 2012, p. 50).

Dentro de este boom de la memoria, el testigo ocupa el lugar protagónico en el sistema de representaciones ${ }^{40}$. Partiendo de la experiencia de la Shoah, en un primer momento reflexionaremos en torno a la figura del sobreviviente de los campos de exterminio nazis y a la figura del exiliado, en relación a la noción de testigo vinculada a la de víctima -a partir de una tipología de intelectuales que pensaron en torno a la Shoah en una primera etapa en Europa y Estados Unidos (Traverso, 2001).

Estas observaciones en torno al caso de la Shoah nos permitirán advertir ciertas claves de lectura y abrir algunas preguntas que nos ayudarán a analizar el caso de los exiliados políticos argentinos, sin dejar de tener una mirada atenta y crítica a las especificidades de cada caso. En un segundo momento, nos acercaremos a las producciones artísticas de los hijos de víctimas de la última dictadura cívico-militar pensándolas, siguiendo a Ana Amado (2009), como prácticas poéticas-testimoniales, teniendo en cuenta las problemáticas específicas que conlleva el concepto de testimonio y sus diferentes funciones -según Paul Ricœur (2004) y Giorgio Agamben (2002).

\section{Las víctimas: los supervivientes y los alertadores de incendios}

En una etapa anterior a esta proliferación de la memoria, en el contexto europeo dominó -citando a Daniel Lvovich (2007)- un período generalizado de silencio o de latencia en torno a la reflexión y la producción historiográfica sobre el nazismo, el fascismo y el régimen de Petain -en Alemania, Italia y Francia-:

\footnotetext{
${ }^{40}$ Traverso, citando a Annette Wiewiorka (1998), afirma que ingresamos a la "era del testigo" (2001, p. $70)$.
} 
(...) es posible sostener que en los tres casos considerados, la potencia del trauma, la cercanía temporal, y las negociaciones individuales y colectivas resultan factores que contribuyen a explicar la dificultosa conformación de las respectivas historiografías nacionales. (Lvovich, 2007, p. 115).

En La Historia desgarrada (2001), Traverso elabora una tipología de cuatro grupos de intelectuales clasificándolos de acuerdo a cómo abordaron, en este contexto generalizado de silencio, las primeras reflexiones sobre el genocidio judío, considerando el compromiso político y la postura intelectual de cada uno. Estos se dividen en los colaboracionistas, los supervivientes, los intelectuales ciegos y los alertadores de incendios. $^{41}$

En el grupo de los supervivientes, Enzo Traverso destaca la profundidad y lucidez de la mirada de los testigos-escritores, sin duda en parte por haber vivido la experiencia concentracionaria nazi. Entre ellos están los que fueron deportados por ser judíos -Jean Améry, Paul Celan, Primo Levi- o por su compromiso político -Robert Antelme, David Rousset, Eugen Kogon. Advierte que la mirada que tienen es subjetiva, parcial, sin una percepción global del sistema concentracionario nazi (al menos en sus primeros testimonios), y sus recuerdos están mediados por sus distintas sensibilidades, mentalidades, ya que pertenecen a contextos culturales y políticos diferentes. No son un grupo homogéneo ni unificado, sino que se mantienen distantes entre ellos, sin redes ni sociabilidades compartidas. Traverso se centra en los escritos de dos supervivientes, Jean Améry y Primo Levi, porque le interesa que su acto de testimoniar es indisoluble del de comprender - por lo tanto abordan las zonas grises-, y porque su experiencia en Auschwitz la ven como una ruptura que modifica la vida y la cultura en su totalidad. Además estos supervivientes están rodeados de un sentimiento de vergüenza y culpabilidad, en muchos casos autodestructivo, llegando incluso al suicidio.

\footnotetext{
${ }^{41}$ Siguiendo al autor, los colaboracionistas o las musas enroladas, abarcan casos muy diferentes, entre ellos los franceses Louis-Ferdinand Céline, Robert Brasillach, Charles Maurras, Pierre Dreu La Rochelle, y en el resto de la Europa ocupada se encuentran Julius Evola, Giovanni Gentile, Ezra Pound, Paul de Man, Knut Hamsun, Leni Riefenstahl, Martin Heidegger. Generalmente fueron cómplices del silencio o contribuyeron con el régimen nazi, y sólo excepcionalmente fueron sus brazos ejecutores. Continuando con las tendencias culturales que se dieron en el período de entreguerras sintieron la "fascinación estética ejercida por el nazismo". El grupo más numeroso es el de los intelectuales europeos y americanos que escriben sobre el nacionalsocialismo y al que Enzo Traverso los caracteriza como ciegos, por su incapacidad en el contexto de la cultura europea surgida de la Segunda Guerra Mundial para ver los campos de la muerte (sólo los intuyen pero sin ubicarlos en el centro de sus reflexiones) y por no considerar a Auschwitz como una ruptura en la sociedad moderna.
} 
Los alertadores de incendios ${ }^{42}$ son un grupo de exiliados judíos alemanes, entre ellos Hannah Arendt, Günther Anders, Theodor W. Adorno, Max Horkheimer, Herbert Marcuse -junto con otros intelectuales que pertenecían al mismo círculo como Thomas Mann, Dwight MacDonald, Karl Jaspers, Vladimir Jankélévitch y George Bataille- que migran a Estados Unidos y colocan a los campos de la muerte en el centro de su reflexión. Son los únicos, junto con las víctimas, que ven e intentan pensar Auschwitz, considerándolo como una ruptura de la civilización. Esta especificidad del grupo, explica Traverso, se debe a distintas razones: pertenecen a una misma generación intelectual, han nacido en el cambio de siglo, quedaron marcados por la ruptura de la Primera Guerra Mundial, se formaron en la república de Weimar y se exiliaron con la llegada del nazismo. En Paris y en Nueva York conforman un medio intelectual del exilio, con redes y círculos en torno a algunas revistas como Aufbau y asociaciones o instituciones científicas como la Escuela de Fráncfort (acogida en la Universidad de Columbia) y la New School for Social Reserch. Sus miradas de "extranjero", su extraterritorialidad, les confiere una perspectiva crítica: "Su marginalidad les aboca casi naturalmente a cumplir la función crítica que, desde siempre, constituye la auténtica vocación intelectual: encarnan la heterodoxia, piensan de otro modo, son disidentes." (2001, p. 42).

En la mayoría de los casos el judaísmo no representa un refugio espiritual, sino que contribuye a acentuar su condición de outsiders y parias cosmopolitas: "su punto de vista no es ni americano ni alemán, ni tampoco el del judaísmo oficial (religioso o sionista). Su perspectiva es la del judaísmo paria, de una minoría de apátridas huidos de la masacre que tiene lugar en Europa." (2001, p. 43). Traverso, afirma, entonces, que son tres las características que posibilitan a algunos de ellos reflexionar sobre Auschwitz: su condición de judíos - no pueden permanecer indiferentes a las noticias del exterminio de sus correligionarios-, de exiliados -ajenos a los condicionamientos de las mentalidades y de su entorno, captan inmediatamente el alcance de los acontecimientos, "pues el genocidio significa el hundimiento irreparable y definitivo del mundo que los ha engendrado" (p. 43)-, de asimilados -no pueden interpretar a Auschwitz con categorías puramente judías, como un acontecimiento ligado a la desgraciada historia del pueblo judío.

\footnotetext{
${ }^{42}$ Expresión de Walter Benjamin retomada por Traverso (2001).
} 
De esta tipología expuesta, nos interesa resaltar que prácticamente son los exiliados (que, por su condición de judios, exiliados y asimilados, son también víctimas del genocidio) y los supervivientes (escritores-testigos) los primeros que sitúan a Auschwitz en el centro de su reflexión, pensándolo no como un accidente en el progreso de la humanidad, sino como su producto legítimo y auténtico de la civilización occidental: la racionalidad instrumental puesta al servicio de la masacre. En este sentido es interesante indagar en la relación entre el grupo de supervivientes (muchos entre los cuales también tienen la condición de exiliados) y los hijos de estos sobrevivientes (y eventualmente exiliados) focalizando en la transmisión de los recuerdos de los campos de la muerte y en el acto de testimoniar. A partir de lo expuesto, pasaremos a relacionar y reflexionar sobre esta tipología y el caso de los hijos de exiliados.

La red de transmisión del pasado traumático que construyen los/as hijos/as, la (pos)memoria ${ }^{43}$, viene a ocupar -junto con muchas otras prácticas sociales que se insertan de distintas maneras- el lugar dejado por la generación de "supervivientes" testigos-escritores (ya son muy pocos los sobrevivientes que quedan entre nosotros) y/o exiliados, y viene a continuar y reconfigurar el acto de testimoniar -con sus distanciamientos, conflictos y reapropiaciones- a partir de la memoria-familiar- de la experiencia de los campos concentracionarios nazis.

Aún cuando pongamos en duda el alcance de las reflexiones de Traverso para repensar el caso argentino, aún cuando cuestionemos las categorías que utiliza a la hora de abordar las especificidades de nuestro contexto $^{44}$; el análisis expuesto nos ayuda a abrir nuevas preguntas: ¿En qué medida la distancia del "extranjero" genera una mirada crítica?, ¿cómo conviven la mirada crítica de quien está alejado con la mirada subjetiva de quien es víctima?, ¿el acto de testimoniar del superviviente es indisoluble del de comprender?, ¿cómo ingresa ese comprender en el ámbito de la memoria y la Historia?,

\footnotetext{
${ }^{43}$ En esta tesis pondremos entre paréntesis el sufijo "pos" para dar cuenta de los debates que conlleva el término posmemoria.

${ }^{44}$ Hay que tener en cuenta que, en el campo de estudios de memoria, se ha generado una discusión sobre la "globalización" del caso del Holocausto para interpretar otros hechos traumáticos -en torno al peligro de desdibujar las especificidades de los hechos comparados que permiten una distancia crítica. Frente a esto, Todorov nos alerta sobre el tipo de comparación que se puede hacer con la memoria: "Existe efectivamente el peligro para la memoria ejemplar de quedar diluida en la analogía universal, donde los gatos de la miseria son pardos. Esto sería no solamente condenarse a la parálisis ante la enormidad de la tarea; sería, además, ignorar el hecho de que los campos no representan una injusticia entre las otras, sino el mayor envilecimiento a que el ser humano haya sido conducido en el siglo XX". Y continúa: "La memoria ejemplar generaliza, pero de manera limitada, no hace desaparecer la identidad de los hechos, solamente los relaciona entre sí, estableciendo comparaciones que permiten destacar las semejanzas y las diferencias. Y "sin parangón" no quiere decir "sin relación": lo extremo cohabita en germen con lo cotidiano. Hay que saber distinguir, no obstante, entre germen y fruto" $(2008, \mathrm{pp} .78,79)$.
} 
$y$, en relación a la segunda generación: ¿qué pasa con los/as hijos/as de estos sobrevivientes y/o exiliados?, ¿qué tipo de testimonios tienen ellos?, ¿cómo comprenden?, ¿qué lugar ocupa el arte en este comprender? Si bien el caso que estudiamos en este trabajo es otro -el de las producciones artísticas de la segunda generación de exiliados políticos argentinos-, esta tipología de intelectuales nos obliga a reflexionar sobre esta relación compleja entre testigo, víctima y exiliado.

\section{Las prácticas poéticas-testimoniales de la segunda generación}

Paul Ricœur (2004) y Giorgio Agamben (2002) estudian las distintas aristas que presenta el tema del testimonio: sus características y problemáticas -quebrando la tríada derecho-verdad-justicia-y sus múltiples funciones que exceden el espacio de la Historia y la Justicia. Desde estas reflexiones, abordamos la compleja relación entre lo artístico y lo testimonial en las prácticas poéticas-testimoniales (Amado, 2009) de la segunda generación de víctimas de la última dictadura cívico-militar argentina.

A partir del primer capítulo "Fase documental: la memoria archivada" del libro La memoria, la historia, el olvido de Paul Ricœur (2004) se pueden profundizar en distintas dimensiones del testimonio -superando el carácter meramente informativo- y del proceso epistemológico que parte de la memoria, pasa por el archivo y los documentos, y termina con la prueba documental para servir a un uso histórico en un caso, y a un uso jurídico en el otro. El autor advierte que el testimonio puede ir más allá y servir a múltiples usos -y más adelante veremos que es en este espacio más amplio donde se puede colocar la realización de una producción artística.

Ricœur destaca seis componentes esenciales del testimonio. El primer componente tiene dos vertientes articuladas entre sí: la aserción de la realidad factual del acontecimiento relatado -donde se pone en juego la frontera entre realidad/ficción-, en la cual la información relatada, el hecho atestiguado, debe considerarse importante; y la autentificación o certificación de su autor, su presunta fiabilidad. Esta relación entre ambas líneas es lo que va a llevar a ciertas problemáticas sobre testimonio, en la relación entre confianza y sospecha, que profundizaremos más adelante. Yo estaba allí. Esta frase condensa el segundo componente que propone Ricœur: la aserción de la realidad es inseparable de la autodesignación -marcada por primera persona del singular, el tiempo pasado del verbo y la mención del allí respecto del aquí- del sujeto que atestigua. Tiene un carácter autorreferencial, ya sea porque el testigo que declara se 
nombra a sí mismo, porque se relacionan ciertos testimonios puntuales con el resto de la historia de vida del testigo que declara, o porque el testimonio tiene una impronta afectiva en los hechos relatados. Yo estaba allí. Creedme. Este es el tercer componente esencial del testimonio que propone Ricœur, en donde el testigo se pone en posición de tercero frente a todos los protagonistas de la acción en el momento del testimonio, generando una situación dialogal y con una dimensión fiduciaria en la cual el testigo pide ser creído. Esto exige, entonces, tanto una certificación del testimonio por la respuesta de aceptación del receptor y una acreditación, que pone en juego la confianza y la sospecha. Si no me creéis, preguntadle a algún otro. A partir de la posibilidad de sospecha, y generalmente en un espacio público donde se enfrentan varios testimonios y testigos, el testigo, en este cuarto componente, acepta ser convocado y responder frente a otros testimonios que pueden llegar a ser contradictorios a su relato. El quinto componente esencial que propone Ricœur es la capacidad del testigo fiable de mantener en el tiempo su testimonio, reiterándolo en distintas ocasiones. El autor sostiene que la identidad subjetiva tiene dos dimensiones: ipse, que se refiere a los cambios que una persona puede tener a través de toda su historia, e idem, la responsabilidad que tiene esa persona de asumir todos los actos de su vida, aun habiendo cambiado a lo largo de ésta. En este sentido, el testigo debe ser capaz de responder por sus afirmaciones y repetirlas (aunque estas narraciones tengan un carácter performativo) ante cualquiera que le pida dar cuenta de ellas.

En las producciones artísticas de la segunda generación se pueden rastrear, al mismo tiempo, estos componentes esenciales mencionados por Ricœur en su versión más protocolar -en el sentido de un testimonio sobre una realidad factual, con autenticidad, un acontecimiento significativo de la historia, con un "yo" (o varios); con un tú a quien se testimonia; con un espacio público y de intercambio y que puede servir a la Historia y/o la Justicia. Pero, a su vez, muchas de las prácticas poéticotestimoniales muestran otras caras del testimonio. Entre ellas, el tema de la intimidad y lo afectivo presente en muchas de las producciones -especialmente aquellas que exhiben fotografías del álbum familiar o donde se exponen sentimientos y sensacionesno responde al tipo de acontecimiento importante de la Historia o la Justicia, no es posible "verificar" su verdad tal como puede hacerse con los testimonios confrontados con lo "real". Además en muchas producciones se da una puesta en crisis del carácter transparente del testimonio, por medio de distintas estrategias que buscan remarcar la subjetividad del testimonio y su doble pertenencia de realidad/ficción, es decir, buscan 
derrumbar en parte su presunta fiabilidad -a través del dispositivo artístico mismo. Algunos ejemplos de estas estrategias son, entre muchas otras, mostrar el montaje de fotografías diferentes de forma explícita en la obra en, por ejemplo, Arqueología de la ausencia de Lucila Quieto; o presentar las dudas que plantea Inés Roqué en Papá Iván en torno al audiovisual en el mismo guión; o la mostración de las herramientas con las que se trabaja en, por ejemplo, el audiovisual documental Los Rubios y la frase en el guión donde aparece la problemática de forma explícita: “exponer a la memoria en su propio mecanismo". ${ }^{45}$

Giorgio Agamben (2002), en el primer capítulo "El testigo" del libro titulado Lo que queda de Auschwitz. El archivo y el testigo. Homo Sacer III, problematiza los distintos matices que tiene el acto de testimoniar a partir de la Shoah. Plantea, siguiendo las reflexiones de Primo Levi, que ser testigo (superstes en latín) se convierte en una de las razones que a un deportado lo puede impulsar a sobrevivir, y señala que el hecho de testimoniar no se agota en el juicio, ya que la "verdad" del testimonio tiene una consistencia no jurídica: "lo que hace que el juicio sea imposible: la zona gris donde las víctimas se convierten en verdugos y los verdugos en víctimas" (p. 15). Es decir, se amplía la categoría de un fin meramente judicial, y a la vez, se cuestiona y quiebra la relación entre derecho-verdad-justicia. También Ricœur, como adelantamos, si bien destaca dos de los principales usos -el histórico y el judicial- del testimonio, no obstante señala que los usos del mismo pueden ser múltiples.

En este sentido, Leticia Muñoz Cobeñas, en su libro Las Antígonas y el Estado. Aflicción y resistencia en el relato de mujeres (2012), también aborda los otros usos del testimonio y se focaliza en la dimensión de la "socialización del dolor" para la construcción de memoria. Desde la antropología de las emociones, analiza las marcas subjetivas de emocionalidad en los relatos de las mujeres que vivieron la Guerra Civil y el franquismo en Cataluña y el terrorismo de Estado en Argentina, y afirma que:

Historizar y narrar desde la vivencia de la aflicción, hablar sobre la experiencia límite amplifica, efectivamente, la construcción de la memoria que es individual y social y alienta a la socialización del dolor y del recuerdo, en una dimensión complementaria al registro que pueda darse del relato en los ámbitos jurídicos para hacer justicia. Recobra la dimensión más humana, externaliza, transmite $\mathrm{y}$

\footnotetext{
${ }^{45}$ Varias propuestas de la segunda generación vienen a coincidir con la crítica de Beatriz Sarlo (2012) sobre la autoridad del testimonio para dar cuenta de "la verdad", más adelante desarrollaremos este tema.
} 
transforma la experiencia y la construcción de la memoria. (2012, p. 217).

Siguiendo esta línea nos interesa apuntar que en las producciones artísticas de hijos lo testimonial no tiene solamente un fin historiográfico o jurídico ${ }^{46}$, sino que también tiene otros fines, entre ellos poner en escena pública otras memorias más personales e íntimas, como afirma Ana Amado: “(...) la memoria subjetiva que recrea y anuda sus avatares biográficos, los fragmentos de su propia experiencia existencial de la muerte, la memoria y el olvido, con la historia." (2009, p. 129).

Giorgio Agamben señala que "testigo" en griego se dice martis, mártir, del cual deriva el término martirio utilizado por los primeros padres de la Iglesia para indicar la muerte de los cristianos perseguidos que daban testimonio de su fe. Si bien aclara que hablar de martirio para referirse a las víctimas del nazismo genera que se mistifique el horror, destaca, sin embargo, dos elementos que se aproximan en ambas situaciones. Uno es el derivado del propio término griego que se refiere al acto de "recordar" y cita como ejemplo a Primo Levi en relación a su gran capacidad de memorizar experiencias y detalles en el campo como "una preparación inconsciente para testimoniar" (p. 26). El otro punto es la interpretación del martirio como un mandamiento divino sin causa aparente, sin pecado. Agamben señala, entonces, que esto se relaciona con las interpretaciones sobre los campos de exterminio porque se presentan privados de sentido. Menciona que el término "holocausto" surge de esa "exigencia inconsciente de justificar la muerte sine causa, de restituir un sentido a lo que no parece poder tener sentido alguno" (p. 27). Luego de hacer un recorrido por la historia semántica del término ligada al cristianismo ${ }^{47}$, el autor destaca también la herencia antijudía que tiene desde el inicio y nos alerta sobre lo que implica utilizar ese término: “(...) establecer una conexión, aunque sea lejana, entre Auschwitz y el olah bíblico, y entre la muerte en las cámaras de gas y la "entrega total a motivos sagrados y superiores" no puede dejar de sonar como una burla. No sólo el término contiene una equiparación inaceptable

\footnotetext{
${ }^{46}$ El fin jurídico está presente en diversas prácticas de H.I.J.O.S. En el caso, por ejemplo, de los escraches hay un fin explícitamente jurídico para muchos en el sentido en que con la señalización de la casa del represor se busca visibilizar el caso, mediatizarlo, y generar debate para que en un futuro cercano se lo pueda llevar a la justicia. Asimismo muchas producciones artísticas cuestionan el pasado e ingresan de diferentes maneras a los debates historiográficos.

${ }^{47}$ Cfr.: "El término holocausto inicia la emigración semántica que le llevará a asumir de forma cada vez más consistente en las lenguas vulgares el significado de "sacrificio supremo, en el marco de una entrega total a causas sagradas y superiores" (Agamben, 2002, p. 29).
} 
entre hornos crematorios y altares, sino que recoge una herencia semántica que tiene desde el inicio una coloración antijudía.” (p. 31).

Agamben cuestiona este segundo punto y dice que es un eufemismo - una adoración en silencio- afirmar que Auschwitz es indecible o incomprensible. En este sentido destaca la voz del testigo Primo Levi "no nos avergonzamos en mantener fija la mirada en lo inenarrable." (p. 32). El problema de la representación de la Shoah y sus límites es un debate que ha estado fuertemente presente en los intelectuales europeos. ${ }^{48}$ Sin embargo no nos interesa tanto profundizar en esa discusión ya dada -más allá del debate siempre ha habido obras que, con diferentes estrategias poéticas, han representado el horror- sino, más bien, abordar esa relación compleja entre la representación de horror y esa necesidad o deber de testimoniar.

Respecto a la capacidad del testigo, Agamben explora en lo que le falta, en la laguna, en lo intestimoniable de los "verdaderos", "integrales" testigos, los hundidos, sin historia, sin rostro, y sin pensamiento: "Quien asume la carga de testimoniar por ellos sabe que tiene que dar testimonio de la imposibilidad de testimoniar. Y esto altera de manera definitiva el valor del testimonio, obliga a buscar su sentido en una zona imprevista." (p. 34).

Algunos restos, fragmentos o testimonios desplazados de los testigos integrales aparecen en varias producciones artísticas de la segunda generación, entre ellos un ejemplo claro se muestra en el audiovisual Papá Iván, en donde la voz del "testigo integral" (aunque no se trata de un testimonio desde y sobre un campo de concentración) ingresa a lo largo de toda la película por medio de la carta que el papá le dejó a sus hijos cuando pasó a la clandestinidad, en una suerte de diálogo imposible entre padre e hija. Asimismo, además de esta necesidad de testimoniar o dar a conocer el testimonio de los "hundidos", las producciones de hijos/as amplían ese fin a una suerte de tumba: "Yo creía que esta película iba a ser una tumba, pero me doy cuenta que no lo es, que nunca es suficiente, y ya no puedo más, ya no quiero saber más detalles, quiero terminar con todo esto, quiero poder vivir sin que esto sea una carga todos los días, y parece que no puedo.” Siguiendo a Ana Amado que retoma la idea de "rito de entierro" de Michael de Certeau, se puede ver que este deseo aparece como una constante en las producciones audiovisuales de la generación de hijos: “ (...) realizan el movimiento de ese rito para redistribuir el espacio de los posibles, enterrando a los

\footnotetext{
${ }^{48}$ Para profundizar sobre este debate, ver Saul Friedländer (ed.) (2007).
} 
muertos como medio de fijar un lugar entre los vivos en busca de un duelo no siempre realizable.” (2009, p. 166).

Sin embargo, estas prácticas poético-testimoniales no deben ser pensadas solamente como un deber de testimoniar en lugar de los "hundidos" -en el sentido en que lo plantea Primo Levi- o un ejercicio de "sanación" del duelo para sobrevivir, sino que, también representan espacios de reflexión y de apertura de nuevos sentidos que articulan una nueva mirada sobre los mismos hechos:

No se trata aquí de considerar estas prácticas poéticotestimoniales, volcadas decididamente a lo simbólico, bajo el prisma seductor de la autoridad redentora del arte. Es decir, de una noción del arte utilizada como principio de relación entre pérdida afectiva y trabajo de duelo, por medio de lenguajes e imágenes que se ofrecen a ser leídos desde una estrategia de (auto)consolación. (Amado, 2009, p. 140).

Entonces, si bien esta estrategia de "(auto)consolación” puede estar presente en estas prácticas poético-testimoniales, no es menos cierto que coexiste con otros objetivos -en los cuales nos parece fundamental poner la atención- que se dejan entrever de diferentes maneras. En este punto es cuando nos podemos hacer la pregunta -que iremos abordando de a poco a lo largo del capítulo-: ¿qué cuestiones habilita la mirada artística sobre estas historias traumáticas?, ¿qué usos hace el arte de lo testimonial?, ¿qué corrimientos o dispositivos de distanciamiento generan los hijos/as con sus prácticas poético-testimoniales con respecto a otras disciplinas?, ¿cuál es la especificidad del arte en estos temas? Como estuvimos viendo, cuestionar ciertas narraciones establecidas y abrir nuevas preguntas, revelar nuevos nudos problemáticos, perseguir otros fines además de los judiciales, difundir otras memorias, insertar el mundo privado y cotidiano marcado por la memoria traumática familiar en la esfera pública son algunas de sus especificidades.

En este sentido, uno de sus objetivos es poder transmitir al otro -ajeno- la historia traumática "privada" desde lo poético-testimonial. Retomando a Paul Ricœur, el testimonio es una institución, creada por una "competencia del hombre capaz: el crédito otorgado a la palabra del otro hace del mundo social un mundo intersubjetivamente compartido. Este compartir es el componente principal de lo que se puede llamar sentido común.”(p. 214). Entonces, el testimonio es un factor de seguridad y garantía en las relaciones constitutivas del vínculo social, e implica una fiabilidad por parte de 
agentes sociales que contribuyen a la seguridad general, es decir, se hace del testimonio una institución. Las producciones de la generación de hijos -audiovisuales, fotografías, performances e imágenes de todo tipo-, al mostrar otras caras testimoniales de las vida privada, "borronea las marcas de la vida íntima y desliza el yo a la esfera pública: el ser privado se trasviste, entonces, en ser social". (Amado, 2009, p. 128).

A partir de lo expuesto, se pueden ir trazando distintos usos y funciones en estas prácticas poético-testimoniales de la segunda generación que quiebran con la tríada derecho-verdad-justicia. Estas producciones artísticas representan un gran aporte a la construcción de la historia al incluir otros relatos en relación con la última dictadura cívico-militar argentina -sobre la militancia, la violencia política, el terrorismo de estado, el exilio político-, ya que aborda lo testimonial desde otras perspectivas y con otras preguntas, ahondando en las memorias en conflicto y reflexionando más allá de lo planteado en la instancia judicial. En este sentido, y considerando que el derecho no agota el problema de acuerdo a Agamben, se vuelven indispensables estas producciones de la generación de hijos para reflexionar sobre las complejidades del pasado reciente argentino.

\section{Testimonio: ¿verdad o ficción o verdad/ficción?}

Para reflexionar en torno al testimonio, nos resulta difícil pensar en estos pares dicotómicos "verdad" y "ficción" como conceptos que no se excluyen, que coexisten en un mismo objeto, ya sea un relato, una historia de vida, una producción artística o un hecho histórico. Entonces, nos preguntamos: ¿existe una verdad?, ¿cuál es la relación entre experiencia, narración y verdad?; ¿cuánto hay de verdad y cuánto de ficción en un testimonio? ¿Qué actores gestionan laS verdadeS? y, en ese "gestionar”: ¿cuánto hay de ficción?

Beatriz Sarlo (2012) cuestiona el presupuesto de verdad y fidelidad -asociado a la experiencia- que tiene el testimonio en sus usos públicos, es decir, fuera del uso judicial y de su valor moral, y pone en duda la legitimidad que ha tenido en las últimas décadas como recurso más importante para la reconstrucción del pasado -auspiciados en gran medida por el giro subjetivo en el campo de la sociología de la cultura y los estudios culturales en los años 80- en sus distintas formas "no ficcionales": testimonios, historias de vida, entrevistas, autobiografías, recuerdos y memorias, relatos identitarios, etc. A modo de alerta, retoma, entonces, los planteos teóricos deconstructivos dados en 
la década de los 60, en el contexto de la llamada "muerte del sujeto" y del giro lingüístico, que ponen el foco en las formas del discurso antes que en la experiencia: "No hay testimonio sin experiencia, pero tampoco hay experiencia sin narración: el lenguaje la convierte en lo comunicable, es decir, lo común y también funda una temporalidad, que en cada repetición y variante volverá a actualizarse." Sarlo, citando a Derrida $^{49}$, pone en relieve que las bases filosóficas del testimonio autobiográfico son imposibles: "el interés de la autobiografía (Derrida está leyendo Ecce homo de Nietzche) reside en los elementos de una primera persona cuyo único fundamento es, en realidad, el mismo texto (...) No hay fundamento exterior al círculo firma-texto y nada en esa dupla está en condiciones de aseverar que se dice una verdad.” (2012, p. 41).

A su vez, la autora se pregunta en qué se basa la legitimidad de aceptar teóricamente las múltiples verdades subjetivas posmodernas, dejando de lado la Historia y su Verdad: "Cuando nadie está dispuesto a aceptar la verdad de una historia (lo que Walter Benjamin denominó los "hechos" reificados), todos parecemos más dispuestos a la creencia en las verdades de unas historias en plural (plural: esa inflexión del paradigma que ha ganado la más alta categoría, lo cual es afortunado, pero también se propone como solución verbalista a cualquier cuestión conflictiva.)" (2012, p. 52).

Con este trasfondo teórico, Sarlo entonces pone en relieve las precauciones que hay que tener sobre la dimensión intensamente subjetiva de la palabra que caracteriza el presente. En este sentido, focaliza su crítica en dos cuestiones que tienen por objetivo generar un relato "completo" y de carácter "realista-romántico": el uso de la primera persona, que tiende a dar un sentido único a la historia (forzando entonces los sentidos que se escapan a éste); y la acumulación de detalles y precisiones, que crean la ilusión ¿ilusión?- de que lo que se narra proviene de lo concreto de la experiencia. Este modo "realista-romántico" genera en el receptor una credibilidad en el narrador y en su narración. Y esto es lo que le crítica Sarlo a estas narraciones: no se le aplican el mismo principio crítico que se ejerce sobre la historia, ya que la memoria tiene un estatuto irrefutable: "Cuando una narración memorialística compite con la historia y sostiene su reclamo en los privilegios de una subjetividad que sería su garante (...), se coloca, por

\footnotetext{
${ }^{49}$ Anteriormente a Derrida, Paul de Man define la autobiografía con la figura de la prosopopeya, es decir, "el tropo que otorga la palabra a un muerto, un ausente, un objeto inanimado, un animal, un avatar de la naturaleza. Nada queda de la autenticidad de una experiencia puesta en relato, ya que la prosopopeya es un artificio retórico, inscripto en el orden de los procedimientos y de las formas del discurso, donde la voz enmascarada puede desempeñar cualquier rol: garante, consejero, fiscal, juez, vengador (enumera de Man). La voz de la autobiografía es la de un tropo que hace las veces de sujeto de lo que narra. Pero no podría garantizar identidad entre sujeto y tropo (...) no hay verdad sino una máscara que dice decir su verdad." (Sarlo, 2012, p. 39).
} 
el ejercicio de una imaginaria autenticidad testimonial, en una especie de limbo interpretativo.” (2012, p. 94). Sarlo afirma que la legitimidad moral y psicológica que tienen los testimonios en relación a recuperar lo perdido por la violencia del poder "no es suficiente para fundamentar una legitimidad intelectual igualmente indiscutible".

En este punto, no nos interesa tanto la discusión de cómo consiguen legitimidad estas voces o cuánto hay de "verdad" en ellas -algunos de estos temas los abordamos más adelante. Pero sí nos resulta útil la advertencia de Sarlo sobre los mecanismos que exponen estas voces para dar cuenta de una experiencia real, en la medida en que, al confrontarlas con las prácticas poético-testimoniales emergen las especificidades de lo poético en estas producciones. Por un lado, las prácticas poéticas en muchos casos retienen del testimonio la apuesta a lo real (aun cuando también reconozcan su “construcción"), pero, por el otro ejercen su propia torsión al modo "realistaromántico", el cual es alterado, reemplazado o exacerbado, en muchos casos, por otras formas estéticas en las producciones de hijos/as. Lo poético, en este sentido, irrumpe en el testimonio "protocolar" o en sus variantes de usos públicos, y produce un distanciamiento crítico en el espectador: ya no se focaliza sólo en el qué se dice sino, además, en el cómo se dice. Emergen a la vista dos grandes grupos de poéticas diferentes en las obras de hijos/as en relación a lo testimonial. Un grupo estaría conformado por aquellas producciones en donde se quiebra ese modo "realistaromántico" por distintas operaciones metafóricas/alegóricas. Por ejemplo en los dibujos de Tomás Alzogaray con la representación del "niño-adulto" -que veremos en el capítulo 5-; o en el audiovisual Los rubios de Albertina Carri se construyen situaciones a partir de unos muñecos Playmobil; o en novelas donde aparece el humor y la ironía; o, dentro de la generación de hijos/as de víctimas de la Shoah, en el cómic Maus de Spiegelman donde los judíos son representados como ratones, los nazis como gatos y los polacos como cerdos; como afirma Andreas Huyssen:

(...) El cómic alternativo; sin embargo, no resulta apropiado ni para la autenticidad mimética, realista, ni para una interpretación radicalmente antimimética, fracturada en términos vanguardísticos. El reconocimiento de la inexorable inautenticidad deviene condición necesaria para una nueva forma de autentificación, para una representación literaria e ilustrada del Holocausto prácticamente inconcebible hasta el momento en que llega a conformar una nueva dimensión de efectos de realismo, 
precisamente a través de su consecuente alegorización. (2007, p. 127).

Y el otro grupo donde se exacerba el modo realista-romántico desde el uso del dispositivo artístico mismo (como la fotografía o el cuerpo), pero que, a su vez, cuestiona esa "autenticidad testimonial". Esto aparece, por ejemplo, en Fotos Lavadas de Soledad Sánchez Goldar, con el tratamiento que desdibuja las fotografías, o en Arqueología de la ausencia donde Lucila Quieto crea una suerte de "testimonios ficcionales" al sacar en una misma foto a los padres desaparecidos justo con sus hijos/as -en el tercer capítulo sobre fotografía abordaremos más en profundidad dichas operaciones.

\section{Posmemoria: debates en torno a un concepto}

Dentro de esta era de la memoria y del testigo surge, a finales de la década de los 80, el término posmemoria, para estudiar el caso de la generación siguiente -los hijosde aquellos que han sido víctimas de los genocidios políticos del siglo XX. El término fue acuñado y desarrollado en mayor medida en producciones culturales de Estados Unidos y Europa, analizando especialmente el caso de la generación posterior a la de los sobrevivientes de la Shoah, pero que también es repensado -y cuestionado- para la generación de hijos de las dictaduras de Estado del Cono Sur. Mónica Szurmuk (2009) en el Diccionario de estudios culturales latinoamericanos menciona las principales problemáticas y traza un panorama de los estudios y las producciones culturales en relación a la posmemoria tanto en Europa y Estados Unidos -destacando los trabajos de Marianne Hirsch y James Young- como en el caso de Bolivia, Perú, Chile, Uruguay y Argentina. Resulta fundamental tener una mirada atenta y crítica con respecto al uso del término en uno u otro contexto: los/as hijos/as de víctimas de la última dictadura cívicomilitar en Argentina se diferencian en varios aspectos de la segunda generación de víctimas de la Shoah. Asimismo, la especificidad de este término es cuestionada por Beatriz Sarlo en su libro Tiempo Pasado, cultura de la memoria y giro subjetivo, una discusión (2012).

Marianne Hirsch ${ }^{50}$, crítica literaria y especialista en género y feminismo, ha trabajado en profundidad sobre el término postmemory ${ }^{51}$ ampliando su campo

\footnotetext{
${ }^{50}$ Nacida en la Rumania de postguerra, hija de sobrevivientes de la Shoah y exiliada a Estados Unidos, es Directora del Instituto para la Investigación sobre Mujer y Género en Columbia University. Sus
} 
disciplinar al incorporar estudios sobre fotografía, historieta y otras producciones culturales. En el ensayo "The Generation of Postmemory" (2008), Hirsch considera la posmemoria como la compleja relación que la segunda generación -los hijos de las víctimas de la Shoah- tiene con las traumáticas experiencias que fueron vividas por la generación anterior, (y que, por lo tanto, tuvieron lugar antes de sus nacimientos), y que son transmitidas de forma tan profunda en el ámbito afectivo que constituyen un tipo de memoria. Para el análisis de este proceso, ella va a destacar la conjunción de tres elementos predominantes en la estructura de la posmemoria en el período posterior a la Segunda Guerra Mundial: la memoria, la familia y la fotografía.

En su ensayo Hirsch reflexiona sobre las cuestiones que implica pensar en una posmemoria, destacando que los hijos de sobrevivientes de hechos traumáticos masivos se conectan de manera tan fuerte con los recuerdos del pasado de la generación anterior que necesitan definir a esa conexión como "memoria". En consecuencia, a esa "memoria" se la considera transmisible entre los que vivieron los hechos traumáticos y los hijos de éstos que no los vivieron. Al mismo tiempo, y de forma un tanto contradictoria, esta "memoria" recibida es distinta del recuerdo de los sobrevivientes (es por eso la insistencia en que sea "post" memoria y no sólo "memoria").

Hirsch, comenta cómo acuñó el término y lo define de la siguiente manera:

Posmemoria es el término al cual llegué en las bases de mis lecturas autobiográficas sobre trabajos de escritores y artistas visuales de la segunda generación. El "pos" en "posmemoria" señala más que un atraso temporal y más que un lugar en las secuelas. Postmodernismo, por ejemplo, se inscribe tanto en una distancia crítica como una interrelación profunda con lo moderno; poscolonialismo (...). Posmemoria nos muestra las capas de esos otros "pos" y de sus atrasos, alineándose con la práctica de la cita y la mediación que la caracteriza, señalando un particular momento en el fin de siglo mirando hacia atrás antes que hacia adelante y definiendo el presente en relación al complicado pasado, antes que iniciando nuevos paradigmas. Al igual que éstos, refleja una incómoda oscilación entre continuidad y ruptura. Y

publicaciones recientes incluyen Family Frames: Photography, Narrative, and Postmemory (1997), The Familial Gaze (1999), Time and the Literary (2002), un número especial de Signs sobre "Género y Memoria Cultural" (2002), y Teaching the Representation of the Holocaust (2004).

51 También, citando a Hirsch (2008), se han utilizado otros términos como "abscent memory" (Fine, 1988), "inherit memory", "belated memory", "prosthetic memory" (Lury, 1998; Landsberg, 2004), "memoire trouée" (Raczymow, 1994), "mémoire des cendres" (Fresco, 1984), "vicarious witnessing" (Zeitlin, 1998), "received history" (Young, 1997). 
aún más, la posmemoria no es un movimiento, método, o idea; yo la veo, más bien, como una estructura de transmisión inter- y trans-generacional del conocimiento y experiencia del trauma. [La traducción es mía] (Hirsch, 2008, p. 106).

Hirsch destaca en la posmemoria el proceso de transmisión entre las generaciones y de esta manera esa memoria que se transmite de la generación de sobrevivientes a la de hijos no está ligada al pasado por medio del recuerdo, sino que se conecta a través de la imaginación, la proyección y la creación. Esas memorias de eventos traumáticos son transferidas a través de relatos, imágenes y comportamientos de todo tipo de manera tan profunda, que, de hecho, conforman las identidades y pueden llegar a desplazar las propias experiencias de los hijos. Como afirma Hirsch: "Esos hechos sucedieron en el pasado, pero sus efectos continúan en el presente" (p. 107).

Hirsch señala que la estructura de la posmemoria esclarece cómo las rupturas introducidas por el trauma colectivo o histórico, por la guerra, la Shoah, el exilio, el refugio, cambian los esquemas de transmisión intra-, inter- y trans-generacional. Estos eventos traumáticos rompen las líneas de conexión entre el individuo y la familia o en el interior del grupo social o en un archivo histórico e institucional -por ejemplo bajo los nazis los archivos culturales fueron destruidos, los registros fueron quemados, las posesiones se perdieron, las historias fueron suprimidas y erradicadas. Si por un lado, la experiencia traumática introduce una ruptura entre el individuo y el espacio familiar y social, por el otro, la posmemoria reconstruye los vínculos quebrados a través de la transmisión de generaciones. Entonces, Hirsch propone:

El trabajo posmemorial, quiero sugerir $-\mathrm{y}$ este es el punto central de mi argumento en este ensayo- se esfuerza para reactivar y reincorporar las más distantes estructuras de la memoria social/nacional y archivística/cultural reinvirtiéndolas con resonantes formas individuales $\mathrm{y}$ familiares de mediación y expresiones estéticas. Es así como los participantes menos afectados pueden verse involucrados en la generación de posmemoria, en la cual entonces el recuerdo puede aún cuando todos los participantes y los descendientes familiares se hayan ido. [La traducción es mía] (Hirsch, 2008, p. 111).

En este trabajo posmemorial, la familia cumple un rol fundamental para la transmisión intergeneracional. Los actos de transferencia no verbal y no cognitivo - 
como el lenguaje del cuerpo- ocurren más claramente dentro de un espacio familiar, muchas veces en forma de síntomas. Como afirma Hirsch:

La ficción, el arte, la memoria y los testimonios de la segunda generación están conformados por el intento de representar los efectos del largo tiempo de vivir en cercanía con el dolor, la depresión, y la disociación de personas que son testigos y han sobrevivido el trauma masivo e histórico. Ellos están formados por las confusiones y responsabilidades de ser hijos, por el deseo de reparar, y por la consciencia de que la propia existencia de ser hijo quizás sea una forma de compensación por la inexplicable pérdida. Pérdida de familia, de hogar, del sentimiento de pertenencia y seguridad en el mundo "sangrante" de una generación a la otra, como Art Spiegelman tan apropiadamente puso en su subtítulo de Maus I, "Mi papá sangra historia." [La traducción es mía]. (2008, p. 112).

Hirsch analiza en su ensayo la relación público/privado en las estructuras de transmisión. La vida familiar - privada e íntima- está condicionada por un imaginario colectivo público, por estructuras generacionales de fantasía y protección, y por un archivo de historias e imágenes que influyen en la transmisión del recuerdo individual y familiar. A su vez, para separar la memoria de la segunda generación en particular (la de los hijos de sobrevivientes) de la generación en su conjunto, Hirsch hace una distinción entre una posmemoria familiar y una afiliativa. La familiar, como bien dice el término, se trasmite en el seno de la familia, mientras que la afiliativa es el resultado de la conexión generacional y contemporánea con la segunda generación de los hijos afectados que, junto con estructuras de mediación, podría ser apropiada para abarcar un gran colectivo en una red orgánica de transmisión. A su vez, las estructuras familiares de mediación y representación facilitan los actos filiativos de la generación. El lenguaje de la familia puede convertirse en una lengua accesible de fácil identificación y proyección a través de la distancia y la diferencia.

El otro elemento que juega un rol fundamental como medio en la posmemoria es la fotografía. Para Hirsch las imágenes fotográficas -en especial las familiaresesclarecen la conexión entre posmemoria familiar y afiliativa. Incluso, gracias a estas imágenes, los archivos públicos e instituciones han sido capaces de reincorporar y reindividualizar la memoria "cultural/archivística". Hirsch analiza dos casos en donde 
aparecen imágenes fotográficas: la historieta sobre Auschwitz, Maus, de Art Spiegelman (1987) y Austerlitz (2001) de W. G. Sebald.

Es este pasaje entre el recuerdo personal e íntimo y la memoria colectiva (Traverso, 2001); entre la experiencia vivida (Erlebniz) y la rememoración colectiva (Eingedenken) (Benjamin, citado en Traverso, 2001), el que trabaja (Jelin, 2002) la generación de hijos de sobrevivientes. Es la "segunda generación", "la generación siguiente", "generación bisagra", la "generación guardiana", la "posgeneración" de la Shoah la que conecta entre esa memoria familiar (muy ligada al recuerdo del sobreviviente a partir de una transmisión fuertemente afectiva) y la memoria social, de lazos filiativos.

Por otro lado, Beatriz Sarlo (2012) cuestiona la necesidad de acuñar la noción de posmemoria debido a que considera que los rasgos señalados y teorizados por Marianne Hirsch y James Young ${ }^{52}$ para definir el concepto no son lo suficientemente específicos. Menciona que el carácter vicario del recuerdo, es decir la doble dimensión existente en el acto de recordar, recordar el hecho vivido y "recordar" narraciones o imágenes ajenas -dimensión señalada por James Young- no sería un rasgo específico de la posmemoria porque toda experiencia del pasado es vicaria, es una re-presentación, algo dicho en lugar de un hecho. Por otro lado, el carácter mediado de los recuerdos -que tanto Hirsch como Young lo mencionan como un rasgo diferencial de la posmemoriaes un proceso que se encuentra prácticamente en todas las historias, ya que éstas generalmente son discursos de terceros, filtrados por los medios de comunicación, las instituciones y diferentes actores y contextos. Sarlo -en lugar de utilizar la categoría de posmemoria- hace la distinción entre una memoria restringida, ligada a los protagonistas que tienen una experiencia directa, una captura en relato o en argumento de esos hechos del pasado que no exceden la duración de una vida; y una memoria que, por extensión, es de segundo grado, de segunda generación, de recuerdo público o familiar que está mediada por fuentes secundarias que provienen de los hechos. Pero, dice que en el caso en que se quiera utilizar la noción de posmemoria, ésta sería válida por dos rasgos:

(...) la implicación del sujeto en su dimensión psicológica más personal y el carácter no "profesional" de su actividad. ¿Qué, que no provenga del orden de la

\footnotetext{
${ }^{52}$ Para tener un acercamiento al trabajo de James Young sobre posmemoria, véase Young, J. (2000). At Memory's Edge, U.S.A: Yale University Press.
} 
experiencia subjetiva y de la formación disciplinar, lo diferencia del historiador o del fiscal? Sólo la memoria del padre; si el discurso que provoca en el hijo quiere ser llamado posmemoria, lo será por la trama biográfica y moral de la transmisión, por la dimensión subjetiva y moral. No es en principio ni más ni menos fragmentaria, ni más ni menos vicaria, ni más ni menos mediada que la reconstrucción realizada por un tercero; pero se diferencia de ella porque está atravesada por el interés subjetivo vivido en términos personales. (2012, pp. 130-131).

De esta manera, Sarlo afirma que si un discurso se quiere llamar posmemoria sería por su subjetividad -cuestión central que desarrolla Hirsch en su argumento en relación a lo biográfico-, aunque plantea que "el gesto teórico parece entonces más amplio que necesario": se pregunta si el "post" cumple una necesidad conceptual o si responde al impulso de inflación teórica, convirtiéndose en una novedad conceptual sintonizada con el auge de los estudios sobre subjetividad y "las nuevas dimensiones biográficas". Alerta, entonces, a los teóricos del campo de los estudios culturales (y del Holocausto) que defienden la noción de posmemoria sobre las discusiones ya dadas en el campo de los estudios clásicos sobre la autobiografía ${ }^{53}$.

Tanto Young como Hirsch sostienen que la fragmentariedad es un rasgo diferencial de la posmemoria. Sarlo, al igual que en el caso del carácter vicario y mediado, afirma que no es específico de esta noción y que toda historia es fragmentaria y lacunar, es decir que ese vacío, vacuum, -ocupado en realidad por las operaciones lingüísticas, discursivas y subjetivas- entre el recuerdo y lo que se recuerda está presente en cualquier experiencia de rememoración. Sarlo dice que esa fragmentariedad no es un "vacío constitutivo", sino un rasgo del relato y de las fuentes (exceptúa el caso del Holocausto ya que sólo ahí es posible encontrar un vacío, aunque, más bien, se trata de una imposibilidad). Estas teorías del vacío representacional y lacunar de la memoria estarían en correspondencia con un sentido común contemporáneo radicado en que “cuanto más importante son las preguntas, menos se puede pretender responderlas", una suerte de "irresolución perpetua" (citando a Young) con respecto a los trabajos de la memoria. Por el contrario las representaciones y propuestas por parte del arte abundan y

\footnotetext{
${ }^{53}$ Cfr.: "La inflación teórica de la posmemoria se reduplica así en un almacén de banalidades personales legitimadas por los nuevos derechos de la subjetividad que se despliegan no sólo en el espacio trágico de los hijos del Holocausto, sino en el más amable de inmigrantes centroeuropeos a los que les ha ido bien en América del Norte y pueden encontrar pocos traumas en su pasado que no se refieran a cómo integrarse en las nuevas costumbres y modas (por lo menos esa es la versión de Hirsch, que pasa por el exacto centro de lo que sucedió con su propia familia)". (Sarlo, 2012, p. 134).
} 
muestran que la cuestión no ha permanecido irresuelta, ya que hay una estética de la memoria e incluso "decálogo internacional unificado y fuertemente creador de consenso". (Sarlo, 2012, p. 141).

Más allá del debate planteado por Beatriz Sarlo sobre la pertinencia o no del uso del término posmemoria -y reconociendo que muchos de los mecanismos de la memoria y la posmemoria coinciden- dicha noción recorta de forma operativa, dentro del amplísimo espectro de la memoria, un mundo específico en torno a la generación de hijos. Esto es visible, por ejemplo, en el caso argentino con los hijos de detenidosdesaparecidos durante la última dictadura cívico-militar que han trabajado la memoria de sus padres con producciones culturales y artísticas que los identifican y en la cual plantean especificidades de esta memoria familiar de hechos traumáticos, recortando, entonces, a la memoria en su totalidad.

Ahora bien, no se puede hacer un uso acrítico del concepto, esto es, no dimensionar las profundas diferencias entre el caso de la segunda generación de víctimas de la Shoah y el caso de los/as hijos/as de la última dictadura cívico-militar argentina o de las del Cono Sur. Sin dejar de lado los avances anglosajones en el campo de los Memory Studies, debemos, sin embargo, escapar al formato del "modelo del Holocausto" para poder reflexionar sobre las cuestiones que nos ayuda a visualizar el concepto de posmemoria en nuestro contexto y las diferencias que existen. A grandes rasgos -para un estudio en profundidad habría que analizar cada caso particular de hijo/a- saltan a la vista algunas especificidades del caso argentino que se separan de la generación abordada por Hirsch: los/as hijo/as argentinos han sido desde muy pequeños, en muchos casos, testigos directos e involuntarios de la militancia y víctimas de la violencia del terrorismo de estado ${ }^{54}$. En este sentido, ya no se podría hablar de un corte generacional marcado por aquellos que vivieron las situaciones traumáticas y aquellos que no las experimentaron de forma real y directa - como en el caso que aborda Hirsch con respecto a la Shoah-, sino que, más bien, ese corte generacional implicaría otro tipo de relación con la memoria traumática ${ }^{55}$. En el caso argentino, los hijos no sólo están

\footnotetext{
${ }^{54}$ Como ya es conocido internacionalmente, el secuestro, la desaparición y la apropiación de la identidad de niños fue una práctica sistemática de la dictadura cívico-militar argentina. Las Abuelas de Plaza de Mayo continúan buscando a los nietos apropiados, hasta la fecha han recuperado la identidad de 119 nietos. Por otro lado, el tema de la militancia y la infancia es abordado por distintas producciones artísticas, entre ellas, la película Infancia Clandestina dirigida por Benjamín Ávila y la novela La casa de los Conejos de Laura Alcoba.

${ }^{55}$ Cfr.: "Si debe hacerse una comparación o utilizar alguna analogía o concepto generacional, con la generalización, psicologización y concepto de trauma que esto supone, no sería el concepto de "segunda generación" en el sentido que lo utiliza Hirsch, sino, en todo caso, aquel con el que Susan Rubin
} 
ligados al pasado traumático de sus padres a través de la imaginación, la proyección y la creación, -y transferidas a través de relatos, imágenes y comportamientos corporalessino que, además, tienen sus propios recuerdos de experiencias traumáticas de la infancia. En este sentido -y generando un forzamiento conceptual para ser más clarosse podría decir que los/as hijos/as tienen dos tipos de memorias traumáticas con las que lidiar: aquellas más íntimas del recuerdo traumático vivido desde la infancia y aquellas que corresponde a las memorias dolorosas de los adultos que fueron trasmitidas en el seno familiar; es decir, están presentes dos generaciones afectadas con experiencias directas generadas por el terrorismo de estado. Como afirma María Belén Ciancio (2013), la relación entre el testigo directo y el testigo-escucha (Amado, 2009) ${ }^{56}$ o testigo indirecto en esta generación es más compleja que en el caso abordado por Hirsch -a lo largo de la tesis emplearemos por momentos el término "segunda generación" para el caso de los/as hijos/as argentinos teniendo en cuenta esta doble dimensión testimonial.

Otro rasgo particular dentro del caso argentino, es el lugar central que adquirió el vínculo familiar en los movimientos de derechos humanos. La figura de la maternidad apareció como bandera de lucha con Las Madres de Plaza de Mayo desde los años 1977 y 1978, en plena dictadura cívico-militar, y con las marchas posteriores en reclamo de verdad y justicia. En esta línea también están los reclamos de los familiares, las abuelas $\mathrm{y}$, en especial la de los/as hijos/as que recortan sus propios reclamos y prácticas -como el escrache en H.I.J.O.S. que analizaremos más adelante. Estas organizaciones basadas en el vínculo familiar $-\mathrm{y}$ "en la creencia de que los vínculos familiares son constitutivos, son primordiales" (Jelin, 2012)- y creadas con el objetivo de demandar y denunciar las torturas y desapariciones accionadas por el terrorismo de estado, nos hacen reflexionar sobre distintos ejes de discusión en la relación entre la vida pública y privada y en la correlación entre familia/legitimidad/verdad: ¿en qué medida este

Suleiman llama a los niños pequeños que sobrevivieron a la Shoah: la generación 1.5" (Ciancio, 2013, pp. 5, 6).

${ }^{56}$ Cfr.: "En este sentido, la reiteración que practican con tonos y poéticas diversas en su producción documental termina por constituir una figura propia, la del testigo-escucha, una tercera persona que va al encuentro del relato de lo ausente, de algún modo abierto a la conciencia de un tiempo, un pasado, la violencia, la muerte. Esa figura tercera en la cadena de una post historia, la del escucha podría pensarse, tal vez, desde Walter Benjamin: implícito en el círculo que rodea al narrador - un narrador que tiene que superar el silencio en que lo sumió la barbarie de su experiencia-, el escucha espera recibir sus historias. Es elegido para pensar el desastre, para guardar memoria y, al mismo tiempo, romper con la lógica (y su legitimación temporal) del "haber estado" de una generación. Para distanciarse, en suma, de esa extraña experiencia del sobreviviente que, en el fondo, es el habitante de una historia concluida. El sobreviviente es irremplazable en su experiencia, pero está sujeto a la paradoja de no representar más que a sí mismo. En cambio, el escucha se hace poseedor de lo definitivamente ausente, que es la historia, para proseguirla de alguna manera. Quizás para reabrirla con otra noción del tiempo (noción de pasado y de futuro), para inscribir la posibilidad de una memoria y asegurar una transmisión.” (Amado, 2009, pp. 202, 203). 
"familismo" (Jelin, 2012) otorga legitimidad en la lucha política frente a otros actores que se mueven por el mismo objetivo?, ¿cómo funciona la verdad de quienes han sufrido, de los afectados directos con otras verdades?, ¿qué tipo de conceptualización de familia emerge en estas luchas; la que enlaza a madres/padres e hijos por una razón biológica esencialista -de sangre- o una cultural?, ¿en qué medida la familia está en el "entre" de la esfera pública y de la esfera privada? Jelin destaca una paradoja radicada en que si la legitimidad de la voz pasa por quien es víctima, a su vez: "esta autoridad simbólica puede fácilmente deslizarse (consciente o inconscientemente) a un reclamo monopólico del sentido y del contenido de la memoria y la verdad. El nosotros reconocido es, entonces, excluyente e intransferible.” (2012, p. 25). En este sentido la autora reclama un espacio más democrático e inclusivo para poder desarrollar profundamente la interpretación y la resignificación de las experiencias trasmitidas. En este punto nos resulta indispensable remarcar el carácter político de las memorias, las luchas y conflictos que se dan en las "políticas de la memoria" tanto estatales como de otros actores sociales, en donde las luchas por la hegemonía están siempre presentes: "Se trata de una lucha por mi verdad, con promotores/as y emprendedores/as, con intentos de monopolización y de apropiación.” En este sentido, hay que reconocer el “carácter cambiante de los sentidos del pasado, de los silencios y olvidos históricos, así como el lugar que sociedades, ideologías, climas culturales y luchas políticas asignan a la memoria. De ahí la necesidad de historizar la memoria" (Jelin, 2012, p. 25). Si bien el caso de la segunda generación de víctimas mantiene cierta legitimidad y el rol de emprendedores/as en la lucha basada en el vínculo familiar -y en la cercanía con el dolor, como una suerte de "dolorómetro" que permitía por ejemplo, ingresar o no en la agrupación H.I.J.O.S (Cueto Rúa, 2008) ${ }^{57}$-, no es menos cierto que -como vimos en el primer capítulo y seguiremos profundizando- se producen a la vez diferencias con respecto a la lucha de los otros familiares y ciertas aperturas para repensar desde nuevas miradas los mismos hechos.

\footnotetext{
${ }^{57}$ En H.I.J.O.S. fue debatido en diferentes momentos el tema de quién podía o no ingresar en la organización. En este sentido hubo una restricción en torno al origen de la persona que quería ingresar: "En primer lugar estaban quienes creían que a la organización debían entrar sólo los hijos de los desaparecidos y asesinados ("dos orígenes"). La segunda postura aceptaba también a hijos de exiliados y ex presos políticos. ("cuatro orígenes"). En último término estaban los que no querían hacer restricciones al ingreso ("población abierta"). (Cueto Rúa, 2008, p. 64)". En este sentido, Cueto Rúa afirma: "Las discusiones corrían el riesgo de caer en terrenos extremadamente pantanosos, en los cuales el dolor era la moneda de cambio de la legitimidad. De modo que haber pasado por la situación más dolorosa, la desaparición de ambos padres, otorgaba a los Hijos el "paradójico privilegio" de pertenecer sin dudas a dicha agrupación." (2008, p. 67).
} 
Otra especificidad del caso argentino que se distancia respecto del contexto en que analiza Hirsch, se encuentra entre los/as hijos/as exiliados/as en México que se reconocen en la construcción identitaria argenmex. Como ya vimos en el primer capítulo, en muchos casos cumplieron un rol activo oficiando como mediadores entre ambas culturas y facilitando el ingreso de los padres en lo mexicano.

\title{
Memoria e Historia del Arte: en torno a las producciones artísticas de la segunda generación
}

\section{Entre disciplinas: Memoria, Historia e ¿Historia del Arte?}

\author{
MDA: ¿Y qué es lo que le enoja tanto? \\ GDH: Todo lo que me rodea, el estado del mundo, del \\ mundo del arte también. El enojo y la ira de nada sirven \\ solos. Pero si adoptan la forma de una obra de \\ pensamiento, si cobra forma, su forma, entonces puede \\ aparecer un Guernica.
}

Entrevista a Georges Didi-Huberman

Enzo Traverso (2007) traza las distintas características que existen entre la esfera de la memoria y la esfera de la historia, y, a su vez, sus entrecruzamientos para lograr un mismo objetivo, la elaboración del pasado: "si la historia nace de la memoria, también se emancipa de ella, al punto de hacer de la memoria uno de sus temas de investigación como lo prueba la historia contemporánea", y continúa "La historia tiene así su nacimiento en la memoria, de la cual es una dimensión, pero eso no impide de ningún modo que la memoria devenga en objeto de la historia." (2007, p. 72).

La memoria es subjetiva, multiforme, cualitativa, mediada por el presente - sin responder al tiempo cronológico y lineal del análisis histórico-, moldeada por los acontecimientos y reflexiones posteriores que modifican el recuerdo, está en transformación permanente. Las memorias “individuales” están encuadradas en marcos sociales (Halbwachs, 2011) ${ }^{58}$. La historia, escrita también en presente, "debe

\footnotetext{
${ }^{58}$ Es importante, también, tener presente los problemas que conlleva la noción de memoria colectiva "en la medida en que se la entienda como algo con entidad propia, como entidad reificada que existe por encima y separada de los individuos. Esta concepción surge de una interpretación durkheimiana extrema (tomar a los hechos sociales como cosa). Sin embargo, se la puede interpretar también en el sentido de memorias compartidas, superpuestas, producto de interacciones múltiples, encuadradas en marcos sociales y en relaciones de poder. Lo colectivo de las memorias es el entretejido de tradiciones y memorias individuales, en diálogo con otros, en estado de flujo constante, con alguna organización social
} 
emanciparse de la memoria, no rechazándola sino poniéndola a distancia” (Traverso, 2007, p. 72). Como afirma Traverso, citando a Hobsbawm, el historiador no debe sustraerse a un deber de universalismo, y debe responder a los requisitos de su carácter científico.

Nos interesa, en esta relación entre el campo de la historia y el de la memoria, plantear algunas preguntas en relación al estudio de las imágenes y la Historia del arte: ¿Cuál es la relación entre imagen y memoria?, y ¿entre arte y memoria? ¿Cómo dialoga/confronta la memoria con la Historia del arte?

En esta instancia nos resulta fundamental mencionar toda una serie de estudios de pensadores heterogéneos, que han cuestionado los supuestos básicos de la Historia del arte tradicional y han dirigido su atención a la memoria. Atlas Mnemosyne de Aby Warburg es una de las propuestas más peculiares e importantes en este sentido. Este atlas visual -inacabado-, compuesto entre los años 1924 y 1926, manifiesta una forma de comprender las imágenes en "paneles móviles": en cada panel hay un montaje de imágenes heterogéneas, tanto de producciones artísticas como de la cultura visual. El objetivo del Atlas es explicar el proceso histórico de la creación artística del Renacimiento en Italia que retoma fundamentos de la Antigüedad. Lo novedoso en esta forma de exposición de los temas es la manera de entender a través de un dispositivo visual la propia historia de las imágenes, lo que instaura un orden espacial acercándonos a una perspectiva más antropológica y distanciándonos, a su vez, de una historia del arte tradicional, evolucionista, estético-formalista-: “(...) El atlas es una presentación sinóptica de diferencias: ves una cosa, y otra cosa completamente distinta colocada a su lado. El objetivo del atlas es hacerte entender el nexo, que no es un nexo basado en lo similar, sino en la conexión secreta entre dos imágenes diferentes. Por eso el atlas es una herramienta mucho más visual de lo que puede ser cualquier archivo." (Entrevista a Didi-Huberman, 2010, s/p.) ${ }^{59}$. En este dispositivo visual, Warburg pone de relieve a la memoria, mnemosyne, al afirmar que el lenguaje gestual, las formas cargadas de expresividad -que él denomina como "engrammas de la experiencia emotiva"-son "patrimonios hereditarios de la memoria". Se focaliza, entonces, no sobre la "evolución estética de las formas, sino ante la búsqueda profunda de los fundamentos

\footnotetext{
-algunas voces son más potentes que otras porque cuentan con mayor acceso a recursos y escenarios- y con alguna estructura, dada por códigos culturales compartidos." (Jelin, 2012, p. 55).

${ }^{59}$ Se puede ver la entrevista completa a Didi-Huberman acerca de la exposición ATLAS ¿cómo llevar el mundo a cuestas?, realizada en el Museo Nacional Centro de Arte Reina Sofía, 2011 en la siguiente dirección: www.museoreinasofia.es/multimedia/atlas-entrevista-georges-didi-huberman
} 
psicológicos e internos de la creación artística, ese "intrincado subterráneo de raíces" que el historiador encuentra en el estudio del gesto patético a través de la Antigüedad y el Renacimiento" (Checa, 2010, p. 140).

En este sentido, Warburg cuestiona a la disciplina tradicional, ya que considera que hay que abordar no sólo el polo apolíneo-racionalizador propio de todas las ciencias "duras", sino, también, el polo dionísiaco-movimiento. En esta línea, Warburg introduce el pathos en la historia de las imágenes:

Jugar y saber. Jugar se sitúa del lado del niño y del artista, y saber forma parte de nuestra responsabilidad, saber es tener experiencia y la experiencia nos llega a través de aquellos que nos han precedido. El gran problema es que el saber preferiría que el sufrimiento no existiese, lo cual es imposible. El sufrimiento, al igual que la subjetividad, son elementos imposibles de eliminar en cualquier actividad relativa al saber, No existe saber sin pathos, esa es una de las grandes lecciones de Warburg. En la actualidad, el pathos se encuentra o bien denostado o bien sobreexplotado. (Didi-Huberman, 2011, p. 32).

Actualmente, y desde hace dos décadas, existe una bibliografía extensa acerca de Aby Warburg y su forma de entender la cultura visual. Ha sido redescubierto y profundizado por muchos intelectuales, entre ellos uno de los más destacados es Georges Didi-Huberman ${ }^{60}$. Retomando entonces estos estudios, en conjunto con otros grandes pensadores como Walter Benjamin y Carl Einstein, Didi-Huberman ha estado (re)construyendo una historia de las imágenes diferente a la tradicional.

Nos interesa -dentro del amplísimo repertorio de conceptos críticos que se han estado desarrollando en el campo- el problema epistemológico que surge con la cuestión del tiempo -y, por consiguiente, de la memoria- en la disciplina historia del arte. DidiHuberman, en su libro Ante el tiempo (2011), retoma a los autores ya mencionados y explica que cuando estamos ante una imagen, estamos ante un tiempo complejo, un montaje de tiempos heterogéneos que forman anacronismos. En este sentido, propone un abordaje crítico de la imagen desde los diferenciales de tiempo -tanto de los "másque-pasados" como de los "más-que-presentes"-, desde las anacronías que surgen en esta proliferación de tiempos diversos, es decir, atendiendo a la dinámica propia de la memoria. Propone ahondar en esa paradoja existente en la disciplina de la Historia en

\footnotetext{
${ }^{60}$ De hecho, Didi-Huberman le dedicó un libro al estudio de los conceptos de Aby Warburg en La imagen superviviente. Historia del arte y tiempo de los fantasmas según Aby Warburg (2009). Ed. Abada.
} 
donde por un lado para estudiar una época es fundamental tener una linealidad cronológica y "evitar" el anacronismo -especialmente dentro de la historia positivista y objetiva-, pero por el otro, se acepta que un historiador siempre va a abordar la historia desde su presente $\mathrm{y}$, entonces, va a interpretar los hechos desde, al menos, un anacronismo. Didi-Huberman propone profundizar en esta doble faceta del anacronismo, en tanto que actúa como phármakon de la historia: el anacronismoremedio y el anacronismo-veneno, es decir aquello que ayuda a repensar la historia desde otro punto de vista o aquello que genera un "delirio" de interpretaciones subjetivas. En este sentido, nos recuerda también que la disciplina histórica no es tanto una ciencia del pasado (no existe tal pasado objetivo) como un montaje del saber, una memoria y una poética. Sólo hay historia dialéctica, historia de los síntomas, entendiendo síntoma como algo que aparece e irrumpe el curso normal de a representación y, a la vez, algo que es anacrónico en la linealidad cronológica.

Sin profundizar en el auge actual de los estudios que problematizan la forma de abordar la cultura visual o la historia de las imágenes -esa discusión excede completamente esta tesis, ya que no nos proponemos hacer una "historia de las producciones artísticas de hijos/as"-, nos interesa, sin embargo, tener presentes algunas herramientas conceptuales a la hora del análisis de las imágenes artísticas, entre ellas: el tiempo heterogéneo y anacrónico; el saber racional y el pathos; el montaje del saber. Es decir, nos proponemos utilizar los materiales críticos que vienen más del campo de la memoria y de la cultura visual o del estudio antropológico de la imagen, que de la disciplina tradicional de la Historia del Arte:

(...) hacer la historia del arte fatalmente nos impone hacer jugar cada uno de los dos términos como una herramienta crítica aplicable al otro. Así, el punto de vista de la historia aporta una duda saludable acerca de los sistemas de valores que, en un momento dado, contiene la palabra "arte". Pero el punto de vista del arte -o, al menos, el de la imagen, el del objetivo visual- aporta, recíprocamente, una duda saludable de los modelos de inteligibilidad que, en un momento dado, contiene la palabra "historia". (DidiHuberman, 2011, p. 49).

Siguiendo este planteo en donde hay una retroalimentación crítica del arte sobre la historia y de la historia sobre el arte, entonces, no sería conveniente considerar la historia del arte como una rama particular de la historia: "Pienso, en efecto, que la 
historia del arte debe hacer otra cosa: se confesó capaz de eso en un momento -el que marcaron los nombre de Wölfflin, de Warburg, de Riegl- en que proporcionó a la historia un modelo de rigor analítico así como de invención conceptual. La historia del arte se mostró entonces tan filosóficamente audaz como filológicamente rigurosa (...)" (Didi-Huberman, 2011, p. 50).

\section{Producciones artísticas de la segunda generación}

En esta era de la memoria y del testigo, la proliferación de proyectos sobre testimonios, archivos históricos orales, la creciente cultura de memoriales, la nueva museología son manifestaciones de la necesidad de construcciones culturales e institucionales que puedan incorporar las historias que están ausentes en los archivos históricos o negadas por historiadores tradicionales. "La memoria, entonces, se produce en tanto hay sujetos que comparten una cultura, en tanto hay agentes sociales que intentan "materializar" estos sentidos del pasado en diversos productos culturales que son concebidos como, o que se convierten en vehículos de la memoria [categoría citada de Van Alphen, 1997], tales como publicaciones, museos, monumentos, películas o libros de historia." (Jelin, 2012, p. 70).

Existe un extenso e intenso trabajo de la segunda generación de víctimas de la última dictadura cívico-militar argentina en el ámbito de las artes, tanto en relación a la producción audiovisual, como en fotografía, performance, instalaciones, literatura entre muchas otras disciplinas e interdisciplinas. Dentro de este amplísimo mundo de producciones de hijos, hay un espacio artístico y con problemáticas específicas que trabaja la generación de los hijos de exiliados políticos en México - y que comparte, asimismo, muchos de los desafíos del grupo más basto. Por un lado, la (pos)memoria de estos emprendedores/as de la memoria (Jelin, 2012) devuelve a la memoria reificada una corporalidad, intimidad, e individualidad que le otorga una dimensión afectiva a la historia, una subjetividad particular por la implicación del sujeto en su dimensión psicológica más personal (Sarlo, 2012); y, por el otro, este recuerdo convertido en memoria aspira a ingresar al espacio de la historia para continuar con la tarea de elaborar el pasado aun cuando explora los mecanismos mismos de la memoria. Es en este sentido que se destaca el rol que ocupa la producción poética-testimonial en esta continuidad (sesgada, interferida) de la transmisión del recuerdo individual; como afirma Traverso, (a partir de la reflexión en torno a los escritos de Jean Améry y de 
Primo Levi) el hecho de testimoniar no sólo tiene una función pedagógica para generaciones posteriores, sino que también cumple "una útil labor de 'moralización de la historia', pues la memoria de la ofensa es una condición esencial para restablecer la justicia." (Traverso, 2001, p. 192). El recuerdo, el haber vivido la experiencia de los campos de la muerte, generó (en algunos casos) no sólo una necesidad interior en los supervivientes de testimoniar sino también una exigencia ética de la sociedad, convirtiendo el recuerdo en memoria:

Si el recuerdo de Auschwitz pertenece a los supervivientes de los campos de la muerte, la memoria de la ofensa debe generalizarse al conjunto de la sociedad. Sólo esta dialéctica que vincula recuerdo y memoria -0 parafraseando a Walter Benjamin, la experiencia vivida (Erlebniz) y la rememoración colectiva (Eingedenken)puede conducir a una redención del pasado, a salvar del olvido a los vencidos de la historia, pues mientras el recuerdo está destinado a morir con sus testigos, la memoria puede ser un elemento permanente de la conciencia social. (Traverso, 2001, p. 193).

A partir de lo planteado en los capítulos abordaremos, entonces, las diferentes producciones artísticas teniendo en cuenta las múltiples aristas de análisis: estas producciones parten de la (pos)memoria familiar traumática -con todo lo que implica trabajar y reflexionar sobre las memorias y el trauma-, tienen un componente testimonial -con diferentes usos, además del jurídico-, y un componente poético -en donde verdad/ficción son dos caras de la misma moneda-, pertenecen a una determinada historia del arte -donde forma y contenido son inseparables, y donde, especialmente, veremos la especificidad de los dispositivos artísticos de las obras. En este sentido, se profundizará en relación al uso de la fotografía, el cuerpo -en acciones performáticas- y el objeto como tres dispositivos privilegiados para vehiculizar memorias. 


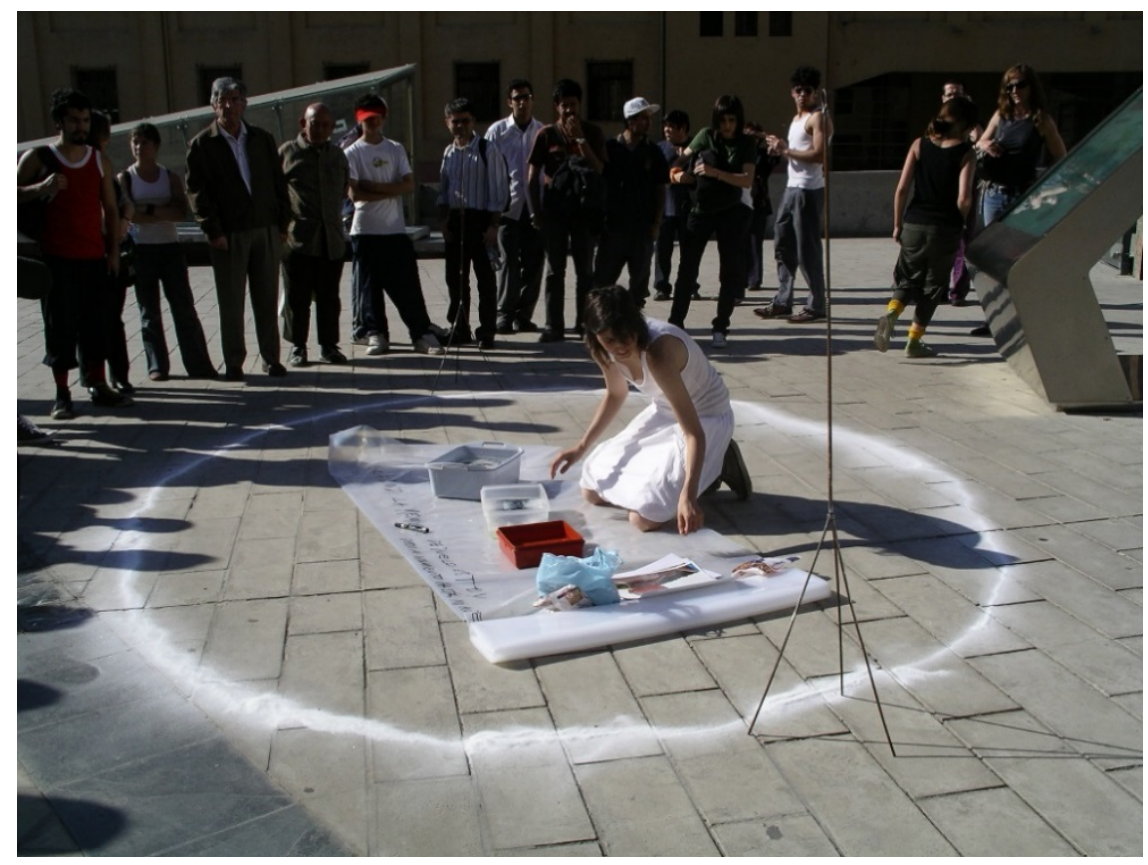

Imagen de la performance Fotos Lavadas de Soledad Sánchez Goldar en la Bienal Internacional de Performance Deformes, Santiago de Chile, 2006. Documentación: Marisa Nino.

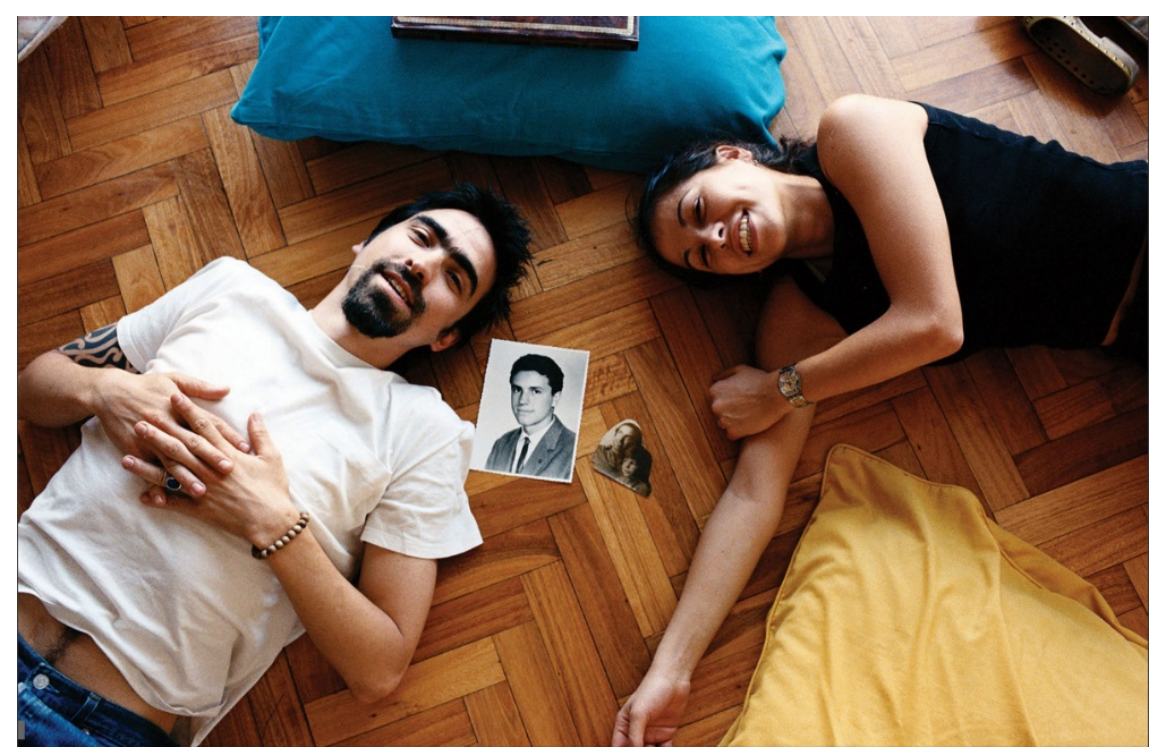

Imagen extraída del libro Fotos Tuyas (2001-2002) de Inés Ulanovsky, sobre Mariano Pujadas "es asesinado el 22 de agosto de 1972 en ese hecho conocido como la "Masacre de Trelew." Tres años después asesinan a sus padres y a sus dos hermanos." 


\section{CAPÍTULO 3. LO FOTOGRÁFICO Y LA MEMORIA}

La fotografía es uno de los principales dispositivos que emerge al momento de reflexionar sobre el trauma colectivo y la historia reciente argentina. A lo largo de este capítulo iremos repasando los múltiples usos de las fotografías no artísticas, entre ellos: la foto como testimonio, prueba y herramienta de denuncia de las desapariciones forzadas de personas por parte de los organismos de derechos humanos, la foto como talismán/reliquia del ser querido adorada por un familiar, la foto del álbum familiar llevada al exilio político como manera de acercar a los parientes o amigos lejanos, entre otros. Teniendo presentes, entonces, estas prácticas y usos de la fotografía, nos focalizaremos especialmente en lo fotográfico dentro de dos propuestas artísticas de hijas de padres exiliados en México: Fotos Lavadas (2005) de Soledad Sánchez Goldar y Fotos tuyas (2001-2002) de Inés Ulanovsky. Reflexionaremos tanto en los usos que se habilitan al abordar las fotos desde la mirada artística -como lugar de elaboración de trauma familiar por ejemplo-, como en los nuevos temas que se trabajan desde la mirada de la segunda generación y el exilio político - la reposición de la biografía del familiar desaparecido/asesinado, los rituales familiares en torno a las fotos que quedaron, la presencia del álbum de fotos familiar, el tiempo condensado entre el que ya no está y el presente de los familiares, entre otros.

\section{De la foto testimonial a lo fotográfico artístico}

Las conocidas fotografías de desaparecidos que formaron parte de la rondas de las Madres de Plaza de Mayo desde los años 1977 y 1978, en plena dictadura cívicomilitar, y las de las marchas posteriores en reclamo de verdad y justicia conforman una de las grandes matrices de representación de la figura del desaparecido en las políticas visuales dentro del movimiento de Derechos Humanos (Ana Longoni, 2010) -la otra gran matriz es la figura de la silueta ${ }^{61} \mathrm{y}$, en otra instancia, una tercera matriz está representada por los escraches de H.I.J.O.S a mediados de los 90'. Estas fotos arrancadas de los álbumes familiares o las fotos tipo carnet del Documento Nacional de

\footnotetext{
${ }^{61}$ Esta segunda matriz se basa fundamentalmente en el encimamiento entre el lector, el espectador, el receptor y el desaparecido, por ejemplo en el caso de El Siluetazo, donde para la construcción de las siluetas es necesario poner el cuerpo del manifestante en el lugar del cuerpo del ausente: "Entonces la silueta vuelta, ya no representación, algo así como huella de dos ausencias, del que prestó el cuerpo solidariamente con el que no está". (Longoni, 2010, p. 10).
} 
Identidad $^{62}$ se llevaban en pancartas en las manifestaciones públicas. Al principio cada madre marchaba con la foto de su hijo desaparecido mostrando el vínculo íntimo afectivo entre ellos, pero, a medida que hubo una mayor organización en la búsqueda y con la propuesta de Hebe de Bonafini de intercambiar las pancartas que cada madre llevaba, con la idea de "somos madres de todos y todos los hijos nos parieron"- se transformó el dispositivo, generando uno nuevo de índole colectivo: cada cual podría llevar cualquier foto, sin tener una relación directa o filial con el desaparecido. Ana Longoni relata también otras propuestas que incluyeron diversos usos de la fotografía, como por ejemplo el mural xerográfico del grupo GAS-TAR (Grupo de Artistas Socialistas - Taller de Arte Revolucionario) que consistía en empapelar con las fotocopias de las fotos de las mujeres y niñas desaparecidas en todo el recorrido de la marcha del 8 de marzo de 1984; la realización de una bandera con las fotos de desaparecidos que se hizo por los 20 años del golpe, y el uso de las fotografías en los recordatorios de Página 12 publicados por la familia o amigos.

Desde la década del 70, entonces, la fotografía ha sido una herramienta de búsqueda y de denuncia de los desaparecidos:

La foto ha sido la manera más directa de tornar visible la desaparición y, a partir de entonces, ha funcionado como uno de los soportes centrales para la reconstrucción de la identidad de cada una de las personas secuestradas, asesinadas y desaparecidas por las Fuerzas Armadas y de seguridad nacionales. (...) No sólo han logrado representarla, sino que en la misma acción han creado un fuerte referente icónico para la denuncia, tanto en el contexto nacional como internacional. (Da Silva Catela, 2009, pp. 337, 338).

La inmensa producción fotográfica en relación a las víctimas de la dictadura cívico-militar sería la contrapartida de la ausencia de fotos y de registro del accionar del terrorismo de Estado -y de la ausencia identitaria en la figura del "desaparecido". Victoria Langland afirma que "No hay fotos del acto de tortura (...) en general podemos decir que no existe una fotografía que resuma, o que pueda representar, la atrocidad masiva del terrorismo de Estado en el Cono Sur." (Como es citado en García y Longoni,

\footnotetext{
${ }^{62}$ Ana Longoni destaca que "hay un acto muy fuerte [por parte de madres] en demostrarle al Estado, que era el Estado desaparecedor, utilizando el término de Pilar Calveiro, el hecho de que también había sido el Estado Identificador, o sea, que el propio Estado que está diciendo que los desaparecidos no existen es el que en algún momento identificó a esos seres con un número de identidad y con un carné de identidad." (2010, p. 3).
} 
2013, p. 32). Sin embargo, García y Longoni afirman que si hay imágenes del horror (que no son secretas ni clandestinas), que no se trata de una carencia, sino de la invisibilización de las mismas ${ }^{63}$ : "en las memorias sobre la dictadura argentina no faltan imágenes sino ojos que las vean, que les den un marco de inteligibilidad y las inscriban en el debate público" (2013, p. 8). Una de las razones de esta invisibilización radicaría en que, como contrapartida de la postura de la irrepresentabilidad del horror ${ }^{64}$, se genera la expectativa de encontrar una imagen-fetiche que condense todo el horror, en una suerte de "La Imagen del Horror", que, como bien analiza Didi-Huberman (2004) resulta imposible de lograr ${ }^{65}$. Lo que sí existe, en cambio, es una multiplicidad de imágenes, de fragmentos que ayudan a la reconstrucción del mecanismo del terrorismo de Estado y la experiencia concentracionaria ${ }^{66}$. La representación visual del horror tendría entonces un carácter "fragmentario (no pleno), múltiple (no único), quebradizo (no definitivo ni último), y performativo (no meramente representativo-indicial)" (García y Longoni, 2013, p. 35).

En relación a la segunda matriz, la de las siluetas como recurso ampliamente conocido de representación del desaparecido -junto con el uso de las máscaras y las siluetas de manos-, Longoni (2010) nos cuenta una disputa que hubo al interior de las

\footnotetext{
${ }^{63}$ García y Longoni (2013) sugieren una clasificación tentativa de estas imágenes en siete grupos: las fotografías de la prensa de la época sobre los operativos represivos, hallazgos de cadáveres, etc.; las fotografías que las fuerzas represivas entregaban a los medios como parte de la información oficial del operativo de detención; las fotografias conservadas de la Policía de Córdoba de la época, que incluyen fotografías de los presos políticos; las fotografías tomadas por miembros de la Dirección de Inteligencia de la Policía de la Provincia de Buenos Aires; las fotografías de ciudadanos argentinos detenidos en Paraguay o paraguayos detenidos en Argentina incluidas en el Archivo del Terror de Paraguay; la conocida foto de las monjas francesas en la ESMA; y el conjunto de fotos que Víctor Melchor Basterra extrajo de la ESMA.

${ }^{64}$ Para ampliar en el debate sobre la representabilidad del horror en la Shoah consultar los artículos reunidos en el libro compilado por Saul Friedlander (2007) En Torno A Los Limites De La Representacion. El nazismo y la Solución Final.

${ }^{65}$ Cfr.: "iPor qué existe esta dificultad? Porque a menudo se le pide demasiado o demasiado poco a la imagen. Si le pedimos demasiado -es decir, 'toda la verdad'- sufriremos una decepción: las imágenes no son más que fragmentos arrancados, restos de películas. Son, pues, inadecuadas: lo que vemos (cuatro imágenes fijas y silenciosas, un número limitado de cadáveres, miembros del Sonderkommando, mujeres condenadas a muerte) es todavía demasiado poco en comparación con lo que sabemos. (...) Son incluso inexactas: al menos les falta esa exactitud que nos permitiría identificar a alguien (...) O quizás es que pedimos demasiado poco a las imágenes: al relegarlas de entrada a la esfera del simulacro (...) las excluimos del campo histórico como tal. Al relegarlas a la esfera del documental (...) las separamos de su fenomenología, de su especificidad, de su sustancia misma. En cualquiera de esos casos, el resultado será idéntico: el historiador tendrá la sensación de que el 'sistema concentracionario no se puede ilustrar'; de que 'las imágenes, sea cual sea su naturaleza, no pueden explicar lo que ocurrió". Y, finalmente, el universo concentracionario simplemente no se puede 'mostrar' puesto que 'no existe ninguna "verdad" de la imagen', como tampoco de la imagen fotográfica, fílmica, ni de la pintada o esculpida'. Y así es como el historicismo se fabrica su propio inimaginable." (Didi-Huberman, 2004, pp. 59, 60).

${ }^{66}$ Un ejemplo comparable al caso que analiza Didi-Huberman (2004) de las fotografías tomadas por los Sonderkommando podrían ser, en el caso argentino, las fotos sacadas por Basterra en la ESMA.
} 
madres. Un sector de ellas se opuso al uso de las máscaras ya que implicaba un borramiento del rostro y una acentuación del anonimato del desaparecido, entonces, como contrapartida, insistían en el uso de la fotografía porque hacía visible un nombre propio, una identidad particular.

Estas fotos, que se destacan, entonces, por la construcción de una identidad y una biografía, son reutilizadas y resignificadas ampliamente tanto por proyectos artísticos de víctimas sobrevivientes de la primera generación como por los de la segunda generación ${ }^{67}$. Son, en palabras de Fortuny (2014), memorias fotográficas y agrego- artísticas $^{68}$. Es necesario aclarar que en este capítulo no analizamos sólo fotografías artísticas sino un espectro más amplio al abordar lo fotográfico dentro de propuestas que exceden a la disciplina pero que sí se mantienen en el interior del mundo de las artes visuales ${ }^{69}$.

Dentro del círculo de fotógrafos de la primera generación que trabajan en torno a la dictadura, mencionaremos especialmente aquellos que han vivenciado el exilio político y que han desplegado su propia experiencia en los proyectos artísticos. Marcelo Brodsky, exiliado en España, incluye en su libro Nexo (2001) una serie llamada Exilios, compuesta por siete fotos y textos que las acompañan en donde se retratan distintas vivencias claves en el exilio -como por ejemplo hablar por teléfono, quemar cosas que ya no sirven, encontrarse con los amigos, entre otras. Es importante destacar que Brodsky es uno de los antecedentes en nuestro contexto del "álbum comentado" (Fortuny, 2014, p. 83), es decir un tipo de producción artística que retoma al álbum de fotos familiar, lo interviene o evoca, e incluye comentarios escritos que completan la obra (por ejemplo en su famosa foto de la división del Colegio Nacional de Buenos Aires de 1967 intervenida y publicada en el libro Buena Memoria, 1996). Por otro lado,

\footnotetext{
${ }^{67}$ En el artículo de Sarah Dornier-Agbodjan "Fotografías de la familia para hablar de la memoria" se destaca a la fotografía familiar como una herramienta de primer orden para la aprehensión de la memoria: "Considerada dentro de la estrecha relación que la liga a sus poseedores, la fotografía de familia evoca sin descanso recuerdos y funciona como una práctica real de la memoria para el grupo familiar." (2004, p. 123).

${ }^{68}$ Fortuny las define así: "Para describir la especificidad de estas obras dentro del conjunto de dispositivos memoriales propongo utilizar el concepto de memorias fotográficas de la dictadura. Con esta invocación, me refiero a artefactos visuales artísticos basados en el recurso de la fotografía que se construyen en diálogo con el pasado reciente. Las memorias fotográficas condensan tres particularidades indisociables: su calidad de memorias sociales de un pasado en común -un juego entre vivencias y memorias individuales y la historia-, su formato visual fotográfico -con todas las potencialidades temporales, estéticas y políticas que este lenguaje comporta- y su elaboración artística -ya que su producción se distingue por la creación y puesta en marcha de recursos visuales singulares en cada obra." (Fortuny, 2014, pp. 14, 15).

${ }^{69}$ Este es el caso de Soledad Sánchez Goldar que utiliza fotografías familiares para realizar su performance y que lo incluimos dentro del capítulo porque consideramos que lo fotográfico ocupa el lugar central en su propuesta.
} 
el fotógrafo cordobés Res, tiene varias alusiones al exilio en México en sus fotografías, por ejemplo en Yo Cacto (1996), en la serie Intervalos intermitentes (1998-2004) y la serie Imanes (1984-1989) que son, según sus palabras, las "fotos del regreso que no pude evitar, casi una insensatez, algo así como buscar la explicación última del magnetismo" ${ }^{\text {70 }}$. Otros fotógrafos de la primera generación son Paula Luttringer, sobreviviente y exiliada en Uruguay, que no trabaja directamente el exilio pero sí los traumas de mujeres en cautiverio; y Gustavo Germano con Ausencias $(2006,2007)$ y, especialmente, Distancias (2008) donde aborda la desaparición y distintos exilios.

En la segunda generación y desde mediados de los 90 hasta la actualidad ha habido una cantidad notable de proyectos artísticos en torno a las memorias afectadas por la última dictadura cívico-militar con nuevas miradas y usos de la fotografía con respecto a estos temas -separándose especialmente del uso dado por los organismos de derechos humanos. En este entorno encontramos también varios hijos artistas que han vivenciado el exilio y que trabajan sobre la memoria traumática, algunos de ellos son Gabriela Bettini, nacida en Madrid en 1977 en el exilio a donde la llevaron sus padres, con la serie Cuarto y mitad (2008); tres exiliadas en México que trabajan con su experiencia en proyectos donde lo fotográfico es central: Inés Ulanovsky con Fotos Tuyas (2001/2002), Soledad Sánchez Goldar en la performance Fotos lavadas (2005) y Mercedes Fidanza con la instalación 7Historias (2008). A su vez, las fotografías son constantemente incluidas dentro de los audiovisuales realizados también por hijos/as de padres exiliados, como por ejemplo en el contexto del exilio en México Papá Iván de María Inés Roqué (2000), Argenmex de Violeta Burkart Noe y Analía Miller (2007); Pasaportes (1997) de Inés Ulanovsky, entre otros ejemplos.

Otros son los enfoques que se ponen en juego en estos ensayos. La fotografía, con su doble régimen de huella/ficción ${ }^{71}$, ya no se concibe sólo con la intención de prueba testimonial para el reclamo de justicia y verdad -ya no responden a la consigna "aparición con vida"-, sino que se pone el énfasis en otros sentidos que trabajan la memoria traumática: el de reponer la biografía del desaparecido; el de crear un tiempo condensado y a veces anacrónico o ucrónico -un tiempo entre tiempos como afirma

\footnotetext{
${ }^{70}$ Cita extraída de la página web del artista: http://www.resh.com.ar/

${ }^{71}$ Es decir, como luego veremos, las fotografías son a la vez testimonio y ficción de lo "real". De allí el carácter inestable señalado por Didi-Huberman respecto al "doble régimen" de la imagen: “(...) los testimonios son subjetivos por naturaleza y están condenados a la inexactitud. Tienen una relación fragmentaria e incompleta con la verdad de la que dan testimonio, pero son también "lo único de que disponemos' para saber y para imaginar la vida interna de los campos de concentración y exterminio" (2004, pp. 58. 59).
} 
Jordana Blejmar (2008)-; el de enfocar los ámbitos privados, familiares, y cotidianos, y su relación con esas imágenes sagradas; el de exponer esa ausencia en la historia familiar y en el presente, entre otros. Estos temas son compartidos por varios de los ensayos fotográficos de la segunda generación -Lucila Quieto, Verónica Maggi, Gerardo Dell' Oro, Camilo Pérez del Cerro, Diego Aráoz, entre otros. En este sentido nos podemos preguntar si la experiencia del exilio es abordada por estos hijos y cuáles son los temas/problemas que se incorporan -teniendo en cuenta también que en los dos casos que analizaremos son hijas de exiliados y sobrinas (no hijas) de desaparecidos.

Aflora, entonces, otro uso de la fotografía en el exilio: aquellas fotografíasobjeto que, por ser pequeñas y livianas, se las podía transportar en la valija y conservar en el país refugio, habilitando la función de reponer y "conocer", en cierta medida, a los familiares argentinos que no estaban con ellos. En este capítulo analizaremos este conjunto de sentidos sobre los usos de la fotografía en dos proyectos artísticos de la segunda generación de exiliados en México: Fotos lavadas (2005) de Soledad Sánchez Goldar, Fotos tuyas (2001/2002) de Inés Ulanovsky.

\section{De la foto íntima y familiar a la foto pública: Fotos lavadas de Soledad Sánchez Goldar}

Un día parece que elegí vivir mi historia, ahora tengo que lograr que vuelva a ser historia.

Soledad Sánchez Goldar

Soledad Sánchez Goldar es una artista argentina, con formación específica en teatro y performance, que actualmente reside en Río Ceballos, Córdoba. Nace en la Ciudad Autónoma de Buenos Aires (Argentina) en 1977 y vive sus dos primeros años en México junto a sus padres, exiliados políticos de la última dictadura cívico-militar argentina. Con una historia familiar fuertemente afectada por el terrorismo de estado (Juan José Sánchez, el padre de Soledad, estuvo secuestrado y sus tíos Alejandro y Eduardo Goldar Parodi, hermanos de su mamá, son detenidos desaparecidos), Soledad trabaja en proyectos artísticos performáticos, de arte objetual y de fotografía que se relacionan de manera consciente con las problemáticas de memoria e historia reciente desde la mirada de la generación de hijos/as ${ }^{72}$.

\footnotetext{
${ }^{72}$ Además de las producciones artísticas, Soledad Sánchez Goldar, junto a socióloga Amanda de la Garza y a la antropóloga Ángela María Moreno Barro, idearon el proyecto de arte e investigación: "Marca y exilio. Pequeñas reconstrucciones de la memoria”. 2009-2011. Recuperado de:
} 
Fotos lavadas (imágenes 1-4) es una performance realizada en un espacio público en donde Soledad lava en una batea fotografías de sus familiares hasta lograr que sus imágenes se desdibujen, borroneen, manchen y cambien de color. Una vez que termina de lavar una imagen se la entrega a alguien del público y vuelve a repetir la acción. Las fotografías pertenecen a sus álbumes familiares, tanto de personas que murieron o viven como de desaparecidos. Esta acción se enmarca dentro de un círculo que ella traza con sal en el suelo, delineando un espacio y conformando lo que ella menciona como "un ritual purificador". Fotos Lavadas es el nombre de cada performance que se ha realizado varias veces desde el 2005 en distintos lugares, como Chile (Valaparaíso y Santiago de Chile) y Argentina (Córdoba, Mendoza, Buenos Aires, Pergamino); conformando de esta manera una serie de acciones.

Podemos encontrar en las acciones dos operaciones diferentes: la primera, de carácter más íntima, donde Soledad en el acto de lavar las fotos genera un ritual, dialogando con su historia particular, su familia; y una segunda más pública en el cual Soledad regala las fotos a los espectadores estableciendo una relación filiativa con las otras generaciones.

¿Por qué lavar las fotos? En primera instancia, el acto de lavar genera un impacto fuerte porque uno lo podría relacionar con la idea de borrar, desdibujar el recuerdo. Pero esto resulta contradictorio con la segunda instancia de la acción (que será analizada posteriormente), en donde Soledad establece una forma de transmitir la memoria entre el público, una comunicación inter/intra generacional que le permite ampliar el círculo de la (pos)memoria. Soledad insinúa de distintas maneras que el acto de lavar las fotos es una suerte de ritual relacionado con su memoria: en el caso de la acción realizada en Santiago de Chile, en el marco de la Bienal internacional de Performances Deformes, aparece una frase inscripta en un plástico en el suelo que dice “(...) De duelo estoy, desde mi nacimiento hasta mi muerte" (imagen 3), en esa misma performance y en la realizada en Buenos Aires en la Feria Periférica del Centro Cultural Borges, Soledad aparece vestida de blanco y, en todos los casos, al menos de los que hay registro, realiza un círculo con sal gruesa alrededor del área de trabajo en donde ella sumerge las fotos en un líquido para desfigurar la imagen. Entonces, "lavar" se entiende en tanto "purificar" o "sanear" una historia familiar dolorosa.

https://sites.google.com/site/proyectoidentidadydocumento/entrevistas 
El ritual de lavar las fotos que Soledad misma denomina como de "purificación" exhibe un intertexto religioso y medicinal: el empleo de la sal se relaciona, tanto en la tradición bíblica (en el Antiguo Testamento, por ejemplo Eliseo sana las aguas malsanas de un manantial con $\mathrm{sal}^{73}$ ) como en otras culturas, con la idea de protección y de purificación; se vincula con un uso medicinal desinfectante, y el blanco connota inocencia y pureza en la tradición occidental. Con este ritual, entonces, intenta establecer, como ella afirma, una comunicación de carácter más íntimo en el interior de su familia, que le permite tener una instancia de duelo y sanación:

Mis proyectos son eso, un medio de sanación, aunque a veces duela, acciones sobre mi historia, acompañadas de pequeños actos poéticos, de pequeños colorcitos, el cuerpo ahí, presente, sin ningún tipo de certeza, sin nada que perder, salvo alguna lágrima o alguna sonrisa. Llegué a hacer esto porque el cuerpo, el alma lo pedía, y lo sigo haciendo por lo mismo. (Sánchez Goldar, página web, 2011, s/p.).

Estas acciones artísticas funcionan entonces como un medio para calmar ese deseo de reparación, ese sentimiento de duelo constante, esa responsabilidad de ser hijos de víctimas -hija de exiliados y sobrina de desaparecidos-, como afirma Marianne Hirsch: "Ellos están formados por las confusiones y responsabilidades de ser hijos, por el deseo de reparar, y por la consciencia de que la propia existencia de ser hijo quizás sea una forma de compensación por la inexplicable pérdida [La traducción es mía]". (2008, p. 112).

Esta operación considerada, entonces, como un ritual de duelo y purificación, se contrapone en cierto sentido a lo planteado por distintos grupos en Argentina en relación a lo que implica generar o no un duelo en un contexto público/político:

Los conceptos de "duelo" y "melancolía" han servido para reflexionar sobre diversos modos de tramitar las pérdidas (desde los ideales revolucionarios de los sesenta hasta el "desaparecido"). En algunos debates en el Cono

\footnotetext{
${ }^{73}$ Libro Segundo de los Reyes, Capítulo 2, de La Biblia (Antiguo Testamento):

19: La gente de la ciudad dijo a Eliseo: "El sitio donde está emplazada la ciudad es bueno, como mi señor puede ver; pero el agua es malsana y la tierra, estéril".

20: Eliseo dijo: "Tráiganme un plato nuevo y pongan en él un poco de sal". Cuando se lo trajeron,

21: Eliseo se dirigió al manantial y echó allí la sal, diciendo: "Así habla el Señor: Yo saneo estas aguas; ya no saldrá de aquí muerte ni esterilidad".

22: Y las aguas quedaron saneadas hasta el día de hoy, conforme a la palabra pronunciada por Eliseo.
} 
Sur, ambos conceptos configuran metáforas de procesos y prácticas de la memoria colectiva o social, y por ello la apuesta por el duelo o la melancolía permite iluminar ciertas tensiones en el interior de la izquierda en, por ejemplo, la posdictadura argentina que aquí elegimos enfocar, entre otras líneas del debate. (Amar Sánchez y Basile, 2014, p. 6).

Lo que algunos grupos ponen en cuestión es que apostar al duelo implica una instancia de superación del dolor y, por lo tanto, de aceptación de la pérdida. Reconocer ese duelo en el plano político sería una forma de "aceptar" las pérdidas ocasionadas por las violaciones a los derechos humanos y finalizar el reclamo al Estado. Es por eso que, algunas consignas políticas o los debates en torno a si debería o no haber tumbas simbólicas para los desaparecidos ${ }^{74}$ se mantienen en una instancia anterior a la del duelo, es decir dan cuenta de la "herida abierta". En este sentido, y para repensar este concepto Teresa Basile y Ana María Amar Sánchez (2014) diferencian, a partir de Freud, las implicancias existentes entre el "duelo" y la "melancolía": en el duelo, el yo reconoce que el objeto amado ya no existe y en consecuencia inicia un proceso de sustracción de la libido del objeto, el abandono de sus ligaduras con el mismo, hasta que el principio de realidad termina por imponerse, y el yo queda libre y exento de toda inhibición para elegir un nuevo objeto. En cambio, perciben en la "melancolía" que la pérdida se vuelve sobre el yo, la libido libre no es desplazada a otro objeto sino retraída al yo, atrapada en las redes de su elección narcisista, sin lograr una retracción de las investiduras necesaria para el establecimiento del estado de reposo. Entonces, esa instancia anterior o más bien ese otro estado que defienden distintos grupos -políticos, artísticos, sociales, entre otros- en la esfera pública se asocia con este complejo melancólico como postura política más que con el proceso de duelo. A su vez, es interesante agregar las categorías que rescata LaCapra (citando a J. Laplanche y J. B. Pontalis que a su vez estudian la teoría de Freud y Lacan) de acting out y working through o elaboración, en cuanto matiza la oposición entre ambas. En el acting out característico de la melancolía- "el sujeto atrapado por sus deseos y fantasías inconscientes, las revive en el presente con una sensación de inmediatez aumentada por su rechazo a reconocer su origen y su carácter repetitivo" y en la elaboración el sujeto implanta una interpretación por medio de un trabajo psíquico que permite aceptar ciertos elementos reprimidos y "liberarse de la presión de los mecanismos de

\footnotetext{
${ }^{74}$ Se dio una discusión de estas problemáticas en torno al Parque de la Memoria en CABA.
} 
repetición" (2008, p. 222), lo que conduciría al duelo. Pero para LaCapra estos procesos -que en Freud se oponen- están imbricados, en tanto "la elaboración es sin dudas una repetición, aunque esté modificada por la interpretación y -por esa misma razón- está en condiciones de facilitar al sujeto a que se libere de los mecanismos de repetición". Lo que da lugar a una "acción responsable", una práctica política ${ }^{75}$.

En el caso de Fotos lavadas, esta problemática se encara desde otro lugar. Soledad realiza, por un lado, un ritual íntimo de duelo que ayuda a generar un desplazamiento del objeto amado en el interior de su familia, es decir pasar del acting out a la elaboración, destacando su trabajo artístico en tanto que "la elaboración no es un proceso puramente intelectual sino que requiere de una forma de trabajo que involucre no sólo lo afectivo sino a toda la personalidad" (LaCapra, 2008, p. 223). Sin embargo, esto permite a su vez que ella convierta esa superación (que destraba la comunicación familiar, logrando que su madre rompa con el silencio y le hable de cosas que antes no le hablaba ${ }^{76}$ ) en un acto político de transmisión de la memoria, o una acción responsable en términos de LaCapra. Una cuestión importante en este proceso es que Soledad no elige las fotos de denuncia de la primera matriz -aquellas tipo carnet utilizadas por las madres-, sino que incorpora otros momentos, situaciones y familiares. En este sentido las fotos del álbum familiar generan un corrimiento y abren otros sentidos y experiencias en los espectadores.

En la operación de entregar al espectador una fotografía con la imagen de un retrato de su familia difuso o desdibujado, Soledad establece un diálogo inter/intra generacional, y transmite la memoria heredada por los hijos (afectados en el seno familiar) a aquellos que pertenecen al mismo contexto histórico pero que no han sido afectados en las redes primarias de la familia. De esta manera expande el círculo memorial a través del vínculo filiativo que se establece con la fotografía:

\footnotetext{
${ }^{75}$ Esta "acción responsable" que plantea LaCapra se puede relacionar con el "uso ejemplar" de la memoria que propone Tzevan Todorov, presentado en el capítulo 2: la capacidad de poder utilizar la memoria de un hecho singular traumático del pasado en una situación nueva, transformando el escenario doloroso en un ejemplo o modelo que ayude a interpretar y comparar los hechos con el presente.

${ }^{76}$ Soledad declara en su blog: "Mi trabajo sobre la memoria más relacionada a mi familia en cierto punto me sirvió a mí y nos sirvió a mi familia para poder hablar de cosas que no hablábamos...como que yo empecé a preguntar más y para mi hoy es un logro que mi mamá pueda hablar de sus hermanos desaparecidos sin llorar como lloraba cuando éramos más chicos y poder contar cosas de ellos separándolos de esa figura de desaparecidos, que era como un hueco que había en mi familia, con este trabajo pudimos construir o reconstruir algunas partecitas de la familia que estaban ahí vacías...no sé si vacías, llenas de dolor más que todo y que imposibilitaban hablar." Sánchez Goldar, S. Blog personal de la artista. Recuperado de: http://www.sanchezgoldar.blogspot.com.ar.
} 
Le regalé las fotografías al público presente que pudo llevarse una pequeña parte de mi familia, mis rostros. (...) Hay una parte de mi historia familiar que fue construida gracias al relato de mi madre, del mismo modo que ella me obsequió sus palabras para que yo pudiera darle forma a esas caras que sólo eran caras en un papel, eran desaparecidos, yo le obsequio al público los rostros de mi memoria, y de mi historia. (Sánchez Goldar, 2006, s/p.)

Estas fotografías implican dos miradas, por un lado la del espectador cercano a Soledad -su círculo familiar- que reconoce los rostros particularizados, los lugares privados, íntimos y cotidianos, las relaciones entre las personas y sus historias de vida, las identidades, etc. Por otro lado las fotografías, al estar inscriptas dentro del género "álbum familiar", en donde se repiten ciertos patrones a los cuales todos estamos acostumbrados, (imagen 2: retratos grupales, distintas técnicas de fotografía según el año en que se tomó, paisajes de viajes, etc.) generan que el otro tipo de espectador ajeno a la familia de Soledad establezca fácilmente un reconocimiento y filiación con sus propias fotografías familiares, invistiendo de esta manera una carga emocional a la fotografía de Soledad. Como afirma Fortuny -citando a Odin:

(...) aunque los recuerdos visuales de cada familia parezcan únicos al referir momentos compartidos por pocos, nada hay más estereotipado que un álbum fotográfico. Es la paradoja de la toma instantánea ritualizada: en cada fotografía hay convenciones que la regulan, dispuestas en ángulos, encuadres, sujetos fotografiados, acontecimientos fotografiables $\mathrm{y}$, por supuesto, las poses y los gestos de estos sujetos como sonrisas, abrazos, mirada a cámara, etc. Las fotografías familiares son objetos no solamente privados, sino impersonales y estereotipados que en general muestran exclusivamente situaciones felices y personas sonriendo (Odin, 2003). (Fortuny, 2008, pp. 78, 79).

De esta manera las fotografías funcionarían como una suerte de espacio prefigurado, inconcluso y generalizador, que exige ser completado por el espectador. Como afirma Marianne Hirsch -en relación a las producciones artísticas sobre el Holocausto:

La fotografía, entonces, es precisamente el medio que conecta memoria y posmemoria. Como huellas, las fotografías registran tanto la vida (los rayos conectando cuerpo con ojo) como la muerte (el momento de registro 
se vuelve fijo con el simple hecho de registrar). Las fotografías del mundo perdido del Holocausto pueden de esta manera contener (...) la particular mezcla de duelo y re-creación que caracteriza el trabajo de posmemoria [La traducción es mía]. (1996, p. 668).

Es, entonces, en esta operación de entregar las fotos al público que Soledad pasa de una instancia más íntima a una colectiva y política, estableciendo la consigna del "no olvido" entre el público, a partir, como mencionamos, del autorreconocimiento o filiación en las fotografías. Además resulta importante mencionar que Soledad también realizó otra instancia pública de filiaciones con otros espectadores en una exposición titulada Fotos de Familia (2006), en la cual colgó fotografías familiares lavadas de la misma manera y tratadas con resina (imagen 5). En este sentido, Fotos Lavadas logra construir una memoria colectiva, convirtiendo lo privado en público, como afirma Soledad en una entrevista "Un día parece que elegí vivir mi historia, ahora tengo que lograr que vuelva a ser historia..." (2011, s/p.)

Esta performance en donde lo fotográfico ocupa un lugar central comparte, como mencionamos anteriormente, algunos de los temas/problemas que se plantea la segunda generación en conjunto -hijos de detenidos, desaparecidos y/o exiliados: el corrimiento del uso de la "foto/prueba" de denuncia y la incorporación de las fotos del álbum familiar; la reposición de la biografía del familiar desaparecido a través de la fotografía; la elaboración, desde lo artístico, de la memoria traumática familiar habilitando espacios nuevos de reflexión y quebrando el silencio familiar-; y la expansión de estas memorias a la comunidad en general. Antes de continuar explorando en estas problemáticas, profundizaremos en el proyecto Fotos tuyas (2001-2001) de Inés Ulanovsky. 


\section{De la foto talismán a la foto artística: Fotos tuyas de Inés Ulanovsky}

(...) tal vez el vínculo entre las fotos y los familiares fue mucho más largo que con la persona en sí, digo, a veces ni siquiera se conocieron con los padres que desaparecieron y el hijo tuvo una fotito toda la vida, y la manera de ver esa foto, y la cantidad de veces que vio esa foto me parecía como muy tremendo.

Inés Ulanovsky

Inés Ulanovsky es una fotógrafa argentina, nacida en Buenos Aires en 1977. En el mismo año de su nacimiento, sus padres -Carlos Ulanovsky y Marta Merkin- se exiliaron a México por segunda vez junto con sus dos hijas -Inés de dos meses y Julieta de ocho años. En enero de 1983 la familia volvió a la Argentina y se instaló en Buenos Aires. Inés estudió Diseño de Imagen y Sonido en la Universidad de Buenos Aires, trabajó en el Archivo Biográfico Familiar de Abuelas de Plaza de Mayo, en el Área audiovisual del Archivo Nacional de la Memoria en la ExESMA, fue editora fotográfica de suplementos del Diario Clarín y coordinó la Fototeca de la Asociación de Reporteros Gráficos de la Argentina. Tanto Fotos Tuyas como Esma son dos proyectos fotográficos llevados a cabo por Inés que abordan el tema de las víctimas de la última dictadura. Pasaportes es un audiovisual que trata el tema del exilio político desde la perspectiva de hijas/os.

Fotos tuyas (2001-2002) es un proyecto sobre nueve desaparecidos y sus familiares. Cada caso está conformado por una serie de cinco o seis fotografías, una o dos cartas que los familiares le escriben a mano alzada al familiar desaparecido y un texto informativo del caso junto con un testimonio de un familiar, realizado por Carlos Ulanovsky. Este trabajo estuvo presentado en distintos formatos: un libro publicado en papel en marzo del 2006, con un prólogo de León Gieco; un video que se puede ver en la página web de Inés y que tiene, además de lo mencionado, las voces en off de los familiares leyendo la carta; y las exposiciones realizadas en distintos lugares como en Buenos Aires (Argentina), el Distrito Federal (México), y en La Habana (Cuba).

Los escenarios privados, íntimos, en los cuales Inés toma las fotos de los familiares -llamaremos a éstas: fotos artísticas-, como el comedor de la casa, los sillones de un living oscuro, la ventana desde el interior de un departamento, el escritorio de trabajo de una mujer, el patio interno de una casa, entre otros, se vuelven más intensos ante el espectador cuando muestran en su interior las fotos de los 
desaparecidos -llamaremos a éstas: fotos/prueba ${ }^{77}$ debido a que se corresponden con la primera matriz mencionada anteriormente, las fotografías de las Madres de Plaza de Mayo $^{78}$. Esas fotos artísticas (imágenes 6, 7 y 8) retratan no tanto las fotos-prueba de las víctimas, como sí los rituales que se generan en torno a ellas, es decir las escenografías en las cuales se exponen familiarmente: en una caja, en un cuadro-objeto sostenido por un familiar, en un cuadro colgado, en una caja de lata, en una computadora, en una valija, en una suerte de afiche artesanal, en un álbum de fotos familiar o en un portarretrato. Además, estos escenarios aparecen, en muchos casos, con la presencia de la hija o el hijo, el papá o la mamá, la hermana o el hermano, o la esposa del desaparecido mostrándonos la foto/prueba, ordenándola o mirándola. A su vez, se expone de un mismo desaparecido la mirada múltiple -en las fotos y en las cartas- tanto de una hermana como de un hijo y de una hija. Se puede notar, entonces, cómo en todas estas operaciones se resalta el vínculo familiar existente con el desaparecido. No vemos tanto la historia del desaparecido, sino la historia de los familiares con los desaparecidos y especialmente, con esas fotos que quedaron ${ }^{79}$. Lo que se destaca en la serie fotográfica es cómo guardan los familiares las fotos, cómo viven actualmente sin la presencia de un padre o un hermano, cómo, en algunos casos, a través de la foto pudo un hijo o hija “conocer" a sus padres, es decir, cómo viven ellos el presente con esa ausencia.

La operación de reconocimiento del espectador en el álbum familiar ajeno mencionada anteriormente para Fotos Lavadas de Soledad Sánchez Goldar -que, por ser un género ligado a una práctica privada, el espectador fácilmente se reconoce y siente empatía por el retratado-, funciona también ahora, pero de manera potenciada por el énfasis que Inés pone en retratar el vínculo familiar y el presente de esas Fotos tuyas del pasado. Este recorte, esta mirada particular que tiene Inés al sacar sus fotos, la

\footnotetext{
${ }^{77}$ La distinción entre "fotos/prueba" y "fotos artísticas" se basa en la finalidad de las mismas, lo cual no significa que ésta sea la única función de dichas fotografías. Las funciones ficcional y documental se articulan conjuntamente en cada caso. La distinción en el presente trabajo es una síntesis que sólo ayuda a reconocer más fácilmente las fotografías de las cuales se está reflexionando.

${ }^{78} \mathrm{Si}$ bien aparecen distintas fotos de los desaparecidos en los retratos de Inés (no sólo las conocidas de "tipo carnet" de las Madres) siguen manteniendo por sus características -fotos viejas, blanco y negro, tamaño carnet- el carácter de foto testimonial/documental.

${ }^{79}$ Inés afirma en la entrevista: "Y a partir de ahí empecé a ver todo lo que ahí pasaba, si había muchas [fotografías], si había pocas, pero sobre todo lo que a me interesaba era esa sensación de registrar el vínculo ese que es tan profundo y tan tremendo y tan auténtico entre las fotos. Y que, tal vez, el vínculo entre las fotos y los familiares fue mucho más largo que con la persona en sí. Digo, a veces ni siquiera se conocieron, los padres que desaparecieron y el hijo tuvo una fotito toda la vida. Y la manera de ver esa foto, y la cantidad de veces que vio esa foto me parecía muy tremendo." $(2014, \mathrm{~s} / \mathrm{p}$.).
} 
desarrolla en una etapa de profesionalización en la fotografía, como afirma en una entrevista, que se desencadena a partir de una marcha del 24 de marzo en Argentina ${ }^{80}$ :

(...) había muchas manifestaciones, actos políticos en México y estaba ya la presencia de las fotos de desaparecidos como algo bastante cotidiano. Entonces yo sabía ya, tenía una consciencia de que en Argentina había una cosa muy dramática. Y esto se me representaba con las fotos de los desaparecidos, que yo no entendía bien qué eran pero me daba como una especie de misterio, de sensación, porque la sensación es que son fotos que están mirando a cámara, en general son de documento, con miradas fuertes. $Y$ todo ese tipo de cosas me generaba como una sensación bastante fuerte, y como una especie de misterio de las fotos de desaparecidos desde muy chica, y siempre pensaba que quería hacer algo con eso, no sabía en qué formato, si video, si foto. (...) Y en 2000 o 2001 no me acuerdo, hice un taller de fotos con Jorge Sáenz, un taller de ensayo fotográfico. (...) Y un día empecé a ir a la marcha del 24 de marzo y saqué fotos de fotos, pero me di cuenta que a mí lo que más me interesaba era el vínculo entre los que tenían las fotos y las fotos. (Ulanovsky, 2014, s/p.).

Es interesante notar cómo Inés relata un cambio en su mirada sobre las fotografías, desde las fotos/prueba -tipo carnet- de desaparecidos llevadas a las marchas en México -con su "misterio" y "miradas fuertes"- a su interés en el vínculo entre esas fotos y los familiares en la marcha en Argentina. En este sentido, se da un pasaje en Inés sobre la relación entre la fotografía y la memoria. Ella parte de esa impresión que le dan las fotos de las marchas en México, las fotos observadas desde el punto de vista de la prueba, el documento, el testimonio, el "certificado de presencia", la "copresencia" metafísica, en donde la atención del espectador es absorbido por ese "esto ha sido", y que coincide con la demanda de "verdad", (más que por la mediación o ficcionalización que conlleva toda foto), como bien describe Roland Barthes:

\footnotetext{
${ }^{80}$ Yankelevich en su libro Ráfagas de un exilio (2009) destaca la atención que los medios de comunicación mexicanos le dieron a la coyuntura argentina (publicando sobre Argentina prácticamente todos los días). Hubo un importante grupo de periodistas argentinos en el exilio. La denuncia de secuestros, torturas, encarcelamientos y asesinatos por parte del trabajo periodístico de académicos y de periodistas argentinos fue tan sistemática -desde 1979 comenzaron a circular los primeros testimonios de detenidos-desaparecidos- que desde un inicio de la dictadura los periodistas mexicanos identificaron a la misma con las más atroces violaciones a los derechos humanos. Un dato que resulta interesante es cómo, a partir del trabajo periodístico dedicado a la lucha de las Madres de Plaza de Mayo, numerosas "exiliadas se ataviaron como las Madres de Plaza de Mayo para exigir aparición con vida de millares de desaparecidos" y cómo se incorporó la consigna "Aparición con vida” entre los desplazados.
} 
Pues la inmovilidad de la foto es como el resultado de una confusión perversa entre dos conceptos: lo Real y lo Viviente: atestiguando que el objeto ha sido real, la foto induce subrepticiamente a creer que es viviente, a causa de ese señuelo que nos hace atribuir a lo Real un valor absolutamente superior, eterno; pero deportando ese real hacia el pasado ('esto ha sido'), la foto sugiere que éste está ya muerto. Por esto vale más decir que el rasgo inimitable de la Fotografía (su noema) es el hecho de que alguien haya visto el referente (incluso si se trata de objetos) en carne y hueso, o incluso en persona. La Fotografía, además, empezó, históricamente, como el arte de la Persona: de su identidad, de su propiedad civil, de lo que podríamos llamar, en todos los sentidos de la expresión, la reserva del cuerpo. (2012, p. 124).

Y luego se desplaza de esa función de la fotografía como prueba, documento, testimonio hacia una función más descriptiva y emotiva del lazo familiar -hay que tener en cuenta que las dos funciones coexisten, sólo que operan de forma diferente en la recepción y una función toma más importancia en un caso y viceversa, es la duplicidad propia del medio fotográfico "huella de lo real que es a la vez metáfora, ficción que a la vez es documento de lo que fue" (Blejmar, Fortuny y García, 2013, p. 13). En este sentido Inés nos propone un punto de vista bien definido, con una mirada particular dentro del amplio espectro de temas relacionados a la fotografía y la memoria.

Ya no interesa tanto el "esto ha sido" sino en cómo - a través de una unión de distintas temporalidades- se quebraron o se fueron reponiendo, suturando esos lazos familiares y cómo se manifiestan en el presente. En este sentido se podría decir que ahí es donde recae la propuesta artística de Inés, en el sentido en que:

Aun cuando a los fotógrafos les interese sobre todo reflejar la realidad, siguen acechados por los tácitos imperativos del gusto y la conciencia. (...) Aunque en un sentido la cámara en efecto captura la realidad, y no sólo la interpreta, las fotografías son una interpretación del mundo tanto como las pinturas y los dibujos. Las ocasiones en que el acto de fotografiar es relativamente indiscriminado, promiscuo o modesto no merman el didactismo de todo empeño. Esta misma pasividad $-\mathrm{y}$ ubicuidad- del registro fotográfico es el 'mensaje' de la fotografía, su agresión. (Sontag, 2012, pp. 16, 17). 
Además de este nivel de intimidad que retrata Inés entre las fotografías de los desaparecidos y sus familiares -ya no es tanto la imagen pública y política del desaparecido en una marcha, sino aquella íntima que se atesora en el núcleo familiar-, también se da una narración, en el sentido en que se muestran tiempos, personajes, acciones y puntos de vista diferentes que ayudan a formar un relato, conformado tanto por las fotos familiares (generando un mini álbum fotográfico) como por las cartas y la información sobre la víctima. Por ejemplo de la cuarta historia referida a Jaime Eduardo, Claudia Inés Yankilevich, Alberto Ezequiel Said, Mario Eduardo Bordesio, desaparecidos entre 1976 y 1978, y Ricardo Aníbal Dios, asesinado en 1976, se muestran cinco fotografías (imágenes 10, 11, 13, 15 y 16), en cuatro de ellas aparecen alternadamente los familiares con las fotos de los que ya no están. En la quinta foto sólo se muestra el presente de los familiares - un retrato grupal, típico de álbum familiar- con una alusión de la falta con una silla vacía. En este sentido se hace hincapié más en el tiempo presente -y futuro- de los familiares que en el pasado de las víctimas. Además tenemos tres cartas, una de Judith dirigida a sus dos hermanos, otra de María dirigida a su papá y otra de Ricky también dirigida a su papá (imágenes 9, 12 y 14). Por último se nos presenta un pequeño relato sobre la detención/desaparición de Alberto y el asesinato de Ricardo acompañado de testimonios ${ }^{81}$. Esta forma de construir una historia enfatiza aún más el carácter descriptivo de la historia del desaparecido -0 , más bien, de la historia de la foto del desaparecido ${ }^{82}$ - en relación con el familiar. Además, como afirma Arfuch: 'si la propia idea de 'album' remite a una estructura necesariamente discontinua, a la irrupción fragmentaria, a las fotos sueltas, mezcladas, incluso desconocidas, que han perdido su anclaje temporal preciso, su existencia supone no obstante la hilación de una historia, un 'antes' y un 'después.'” (2007, p. 48). A su vez, se resaltan, dentro de esta continuidad de la historia familiar, las ausencias y las rupturas familiares ${ }^{83}$. En este punto es necesario destacar un elemento que ficcionaliza la narración: el encuentro entre el tiempo de la foto del desaparecido y el presente de los familiares, una ucronía, un tiempo ficcionalizado formado por la imbricación de un

\footnotetext{
${ }^{81}$ Un detalle no menor es que los testimonios de los familiares a lo largo de todo el libro están conformados a partir de la pregunta -no enunciada- sobre la relación entre ellos y las fotos de sus desaparecidos.

${ }^{82}$ Las fotografías de los desaparecidos expuestas por las Madres de Plaza de Mayo no constituyen una narración, sino que son un instante, la conformación de una imagen contundente que constituye una prueba para reclamar por verdad y justicia.

${ }^{83}$ Entrevista a Inés: “(...) una interrupción en un álbum familiar, en donde de repente no hay más fotos, no hay más registros, no hay más nada, o un álbum al que le faltan un montón de fotos, que fueron sacadas porque se consideraban peligrosas y bueno todo ese tipo de situaciones." $(2014, \mathrm{~s} / \mathrm{p}$.).
} 
tiempo dentro de otro, del montaje de tiempos heterogéneos en la misma fotografía artística (Didi-Huberman, 2011). Si bien este montaje se explicita más en otros casos (como por ejemplo las fotos de Lucila Quieto en donde impera el deseo de convivir en un tiempo ficcional), no deja de crearse un tiempo entre tiempos. (Blejmar, 2008). En este sentido, Fortuny relaciona estas fotografías con la costumbre de retratar al difunto con la familia -si bien ella aclara que en un caso se trataba de una muerte natural y en el caso de Inés de un desaparecido sin tumba-: "Estos retratos confirman la ficción de la reunión de la familia a pesar de la muerte y la ausencia física” (2014, p. 109).

Inés genera, entonces, una instancia de reflexión sobre el tema, traspasando ese fuerte impacto inicial que todo espectador siente al entrar en contacto una foto-prueba, una foto en blanco y negro de algunas décadas atrás del familiar desaparecido -ya sea la foto tipo carnet que usaban las Madres de Plaza de Mayo o alguna extraída de un álbum familiar-, e incentiva un corrimiento en la mirada. Este tipo de operaciones de distanciamiento -tanto focalizar el tema en el vínculo familiar como en generar un relato y un tiempo ficcional- logran que la foto no se agote en el impacto emocional fuerte que generan el tipo de pruebas, testimonios; sino que, al contrario, ayuda a repensar el presente de esos familiares y, por ende, nuestro propio presente. Como espectadores nos sentimos interpelados a ocupar por un momento el lugar de esas personas.

Por último me interesa destacar cómo, en esta exposición del vínculo entre el familiar y la persona desaparecida -o su foto- emergen los distintos cultos familiares o escenarios sacralizados en torno a las fotografías. Esto se evidencia tanto en los contextos familiares, privados, que retrata Inés -en donde se muestran los lugares donde se atesoran las fotos de los desaparecidos- como en los testimonios de sus familiares:

Tuve durante años una foto de ella enmarcada, pero un día el marco se rompió y nunca lo repuse. Ahora, en el primer cajón de mi escritorio, tengo su foto que salió en Página 12. Todos los días la miro un poco. (Fragmento del testimonio de Silvia Lennie). (Ulanovsky, 2006, s/p.).

No me gusta poner las fotos en porta retratos porque, pienso, que de tanto estar expuestas un día se pueden volver invisibles. Prefiero mostrarlas o mirarlas como un acto bastante privado. Las fotos de los muertos queridos, expuestas a la vista cotidiana me provocan una especie de pudor. En un lado o en el otro, las fotos siempre fueron 
una manera de tenerlo presente. (Fragmento del testimonio de Virginia Croatto) (s/p.).

Algunas fotografías fueron conservadas por la familia paterna; otras, de tamaño carné, viajaron con nosotros al exilio en Cuba. Me acuerdo que yo las ponía debajo de mi almohada en una guardería de chicos a los que, a casi todos, les faltaba el padre o la madre. (...) En las paredes de mi casa están colgadas las fotos de mis viejos, o sea que están muy presentes y cotidianos. (Fragmento del testimonio de Águeda Goyochea). (s/p.).

Mi viejo. Se iba mientras yo llegaba. Nunca pudimos vernos las caras. A veces puedo sentirlo, a través de sus fotos" (Fragmento de la carta de José Prieto López). (s/p.).

Yo me crie con mis abuelos paternos. Mi abuela tenía en su mesa de luz una foto de mi papá de cuerpo entero, probablemente la última que le tomaron. Mi abuela vivía con la esperanza de que un día tocaran la puerta de la casa y que sería mi papá. Mi abuela falleció en 1992, cuando yo tenía 16 años. Pocos días después de su muerte, entré a su habitación y, al ver la foto de mi papá, le advertí una expresión distinta a la habitual. Entonces entendí que, finalmente, él y mi abuela se habían reencontrado. (Fragmento del testimonio de Clara Petrakos) (s/p.).

Esta idea de foto/talismán, foto/reliquia es ejemplificado por Susan Sontag: “(...) La foto del amante escondida en la billetera de una mujer casada, el cartel fotográfico de una estrella de rock fijado sobre la cama de un adolescente, el retrato de propaganda del político prendido a la solapa del volante, las instantáneas de los hijos del taxista en la visera "(2012, pp. 25,26) y sintetizado en su expresión "Tener una fotografía de Shakespeare equivaldría a tener un clavo de la Santa Cruz" (p. 150).

Además de este carácter sagrado, indicial, de la foto que aparece en los testimonios citados, la mayoría de los familiares de estos nueve casos cuentan a lo largo del libro que transportaban las fotos en el exilio. En la cita de Águeda Goyochea vemos la importancia de estas fotos/objeto tamaño carnet en su exilio a Cuba -un dispositivo que se vuelve fácil de transportar por su poco peso y tamaño pequeño-, como afirma Inés: "La foto tiene un lugar muy importante [en el exilio]. Además eran fotos que iban y volvían, que viajaban, se mandaban por correo, venían para acá.” (2014, s/p.).

En este punto se pueden destacar tres usos - no artísticos- de las fotografías en el exilio para la segunda generación: para aquellos que tenían algún padre desaparecido, la foto-objeto transportable en la valija ocupaba este lugar sagrado, talismánico; para los 
hijos que estaban lejos de sus familiares o que nacieron en el exilio, las fotos del álbum familiar mantenía de alguna manera presente a los parientes que estaban lejos; y, por último, para todos los exiliados era conocida la función de la fotografía como denuncia de los desaparecidos - como vimos anteriormente, Inés misma comenta cómo aparecen esas imágenes en una marcha en México. Volviendo, entonces, al uso artístico de la fotografía en el caso de Inés, podemos ver cómo ella desplaza esa atención que demanda el carácter sagrado de la foto/reliquia/talismán hacia el ritual que los familiares construyen. Sin borrar el carácter sagrado, Inés nos invita a desplazar la mirada. Si bien aparecen condensadas las funciones de las fotos no artísticas -la sagrada que mantenía un contacto con una madre o un padre desaparecida/o, la de denuncia de la foto carnet "internacionalizada" de las madres o la de acercar a un familiar que estaba lejos-, la fotógrafa nos invita a reflexionar sobre lo que se genera alrededor de eso, es decir al presente de los familiares y a los rituales que se han creado en todo este tiempo con esas fotos.

\section{Lo fotográfico entre lo privado y lo público}

Hay varios puntos en común entre Fotos lavadas de Soledad Sánchez Goldar y Fotos tuyas de Inés Ulanovsky y que, a su vez, se inscriben en el conjunto más amplio de propuestas culturales que viene desarrollando la generación de hijos/as. En primer lugar las autoras de ambos proyectos vivenciaron la experiencia del exilio político en México a muy temprana edad. La fotografía, como vimos, estaba presente de diversas maneras, entre ellas: en las fotos de denuncia de los desaparecidos -Inés nos cuenta que ella las veía en las marchas en el Distrito Federal-, en las fotos del álbum familiar que se transportaban en las valijas y que recordaban a los familiares que estaban lejos, en aquellos hijos que se llevaban una foto del padre o madre desaparecido/a. Estos usos, si bien no aparecen trabajados de forma explícita en los proyectos artísticos de Soledad e Inés, sirven para configurarnos los múltiples y profundos sentidos que contiene el dispositivo fotográfico a la hora de analizar las producciones visuales.

En ambos proyectos aparece la idea de la imagen como presencia, como presencia de la ausencia del desaparecido (Belting, 2012). Y al percibir las fotos como una suerte de imagen sagrada -de hierofanía- se torna necesario generar un culto alrededor de ellas. Soledad quiere desdibujar o decolorar las imágenes. Pero, si uno piensa en este acto, no se animaría a dañar una foto de un ser querido, ni a quemarla, ni 
a romperla, ni a pincharla, ni a borrarla, a no ser que se esté realizando una ritual adrede. Y eso es lo que está haciendo justamente Soledad: para poder lavar las fotografías hace un círculo con sal, se viste de blanco, escribe una frase. Es, claramente, la construcción de un espacio sagrado, un lugar en donde los muertos están cuidados y adorados. Algo similar, aunque un poco menos explícito, aparece en el ensayo de Inés. Ella nos muestra ese vínculo familiar entre el desaparecido y el familiar, pero a través de un objeto, la fotografía. Entonces, lo que se relata es ese culto con el "vestigio", la "reliquia" de la persona desaparecida, como afirma Fortuny: "La foto aquí no es solamente una evidencia o la salvaguarda de un recuerdo: es además y principalmente un objeto. Una cosa que ocupa espacio, se atesora, se apila, se avejenta." (2014, p. 109). Cómo se colocan las fotos, en qué espacio de la casa, junto a quién, cómo se manipulan, qué transmiten, es lo que se destaca en Fotos tuyas. En este sentido, Arfuch reflexiona sobre la función de restauración de la foto ligada al hábito ancestral de la adoración: "Más que una estética de la representación, se trataría entonces de una restauración, un giro hacia un estadio pre-verbal, una dimensión de la imagen que lleva al mundo visual de la primera infancia, esa cámara oscura de los recuerdos que dibuja una especie de topografía de la interioridad." (2007, p. 50).

Esta particularidad del dispositivo fotográfico radica en su componente indicial $^{84}$, es decir, contiene, como huella física, la luz del momento en que se tomó la foto -en las sales de plata expuestas a la luz y luego reveladas. Pero, como se mencionó anteriormente, esta indicialidad de la fotografía es sólo una parte de la misma. Todas las fotografías están mediatizadas, por lo que "trafican simultáneamente con el prestigio del arte y la magia de lo real. Son nubes de fantasía y cápsulas de información" (Sontag, 2012, p. 74). Schaeffer nos alerta en este sentido sobre la relación entre imagen fotográfica y testimonio: "La estrategia del testimonio se aprovecha por consiguiente de

\footnotetext{
${ }^{84}$ Según Charles S. Peirce, el índice es uno de los tres niveles del signo. La particularidad del índice es que mantiene con su referente una relación directa, física, de derivación, de causalidad. Se encuentra en contigüidad con el objeto denotado. François Soulages, citando a Dubois, dice: "El índice evoca entonces al referente gracias a una huella o a una impresión; es un `signo que significa su objeto, con frecuencia en virtud del hecho de que realmente se halla en conexión con él: la fotografía es entonces índice. (...) Esta tripartición de Pierce remite a tres maneras de recibir una foto: el ícono insiste en el referente, el símbolo en el receptor que, a voluntad, puede dar un sentido nuevo a la foto, el índice en el productor de la foto. El ícono es reivindicado por fotos sin-arte -documento, fotografía de familia y en particular fotografía de los desaparecidos, como para Barthes y Duperey, autorretrato y autobiografia-; el símbolo, paradójicamente a la vez por fotos unitarias y fotos que querrían formar parte del arte, y el índice por toda la fotografía, lo que autoriza, hasta solicita, ese pasaje del sin-arte al arte, como en Denis Roche, Bernard Plossu y Christian Boltanski. La concepción de la fotografía como índice, pues, deja intacto el misterio del objeto por fotografiar, porque si ella "certifica, ratifica y autentifica (...), esto no quiere decir que significa", escribe con exactitud Dubois." (2010, p. 97)
} 
una ambigüedad constitutiva del estatuto semiótico de la imagen fotográfica, a saber, el hecho de que sea a la vez indicial e icónica”. (1990, p. 105). Blejmar, Fortuny y García (2013) nos advierten sobre el tipo de verdad que se construye en las imágenes fotográficas. Junto con el famoso libro de Roland Barthes, La cámara lúcida. Nota sobre la fotografía, varios teóricos han abordado el tema de la fotografía como huella, índice de la realidad, y la fotografía como creación -algunos de estos autores conocidos son Walter Benjamin, Susan Sontag, Rosalind Krauss, Philippe Dubois, François Soulages, Jean-Marie Schaeffer, Georges Didi-Huberman, entre muchos otros. Esta noción de verdad escapa, al igual que la noción de verdad en el testimonio ${ }^{85}$, a la idea tradicional, objetiva y positivista de entender la historia, a esa insistencia de separar la "verdad" de la "mentira", lo "objetivo" de lo "subjetivo", la "prueba" de la "ficción":

¿Es la fotografía, como registro de lo real, pura 'verdad'? ¿Es, como montaje (hiperbolizado en la era digital), pura 'mentira'? (...) la fotografía ha funcionado como un dispositivo que deconstruye la lógica binaria de verdad y falsedad, documento y ficción. Así, no se trataría de reconocer como problema la 'verdad' o la 'mentira' de la foto, de definir si en ellas 'aparecen' los desaparecidos, o si en su superficie estetizada desaparecen por segunda vez. No se trata de asumir posturas iconólatras o iconoclastas, sino de advertir la lectura maniquea que pretende pensarla en estos términos, y (dejándonos orientar por el efectivo uso que familiares, artistas, y militantes han hecho y siguen haciendo del dispositivo fotográfico) atravesar el estrecho territorio de tales simplificaciones para avanzar hacia la singular noción de verdad que porta lo fotográfico, una verdad que, como la de la memoria, es ajena a las dicotomías normalizadoras de la ciencia." (Blejmar, Fortuny y García, 2013, p. 17).

En este sentido, en ambos proyectos artísticos si bien se incorporan aquellas fotos de denuncia donde lo importante es su carácter de evidencia (y no cómo se sacó la foto carnet, qué encuadre o color tiene, etc.), se resignifican tanto por su propia condición de pertenecer al mundo artístico -donde nos exige a los espectadores una mirada particular- como por los temas retratados en las fotografías: el vínculo entre la familia y esas fotos, los rituales para la elaboración del trauma a través de la foto, la biografía del desaparecido/asesinado en el álbum comentado, entre otros. Entonces

\footnotetext{
${ }^{85}$ A partir del primer capítulo "Fase documental: la memoria archivada" del libro La memoria, la historia, el olvido de Paul Ricoeur se pueden profundizar en distintas dimensiones del testimonio superando el carácter meramente informativo.
} 
Fotos lavadas y Fotos tuyas se enfocan menos en las fotos testimoniales y más en el álbum de fotos familiar, en el entorno íntimo y privado de la familia.

Pero, a su vez, en estas propuestas los álbumes de fotos se resemantizan y se tornan públicos y políticos en varios aspectos: en el caso de Fotos Tuyas hay una marco institucional -Secretaría de Cultura de la Nación- que avala la difusión del proyecto en formato de libro; en Fotos lavadas, además de la clara intención de trasmisión intergeneracional de la memoria, la gente es interpelada directamente en la calle, por medio de la performance. Y, además, ambos proyectos están inscriptos en el campo artístico, por lo que participan de todas las estrategias públicas pertenecientes al mismo (exposiciones tanto físicas como virtuales, materiales de difusión, críticas de arte, reseñas, etc.) Se genera, en otras palabras, una movilización del acto repetitivo de la acción ritual -en el caso, por ejemplo, de los familiares que retrata Inés o en el sólo acto de lavar las fotos de Soledad- al trasmitir esas historias a otras personas. Se proyecta ese pasado íntimo y traumático sobre un presente colectivo y político ${ }^{86}$.

\footnotetext{
${ }^{86}$ En este sentido, Fortuny afirma: "Puede pensarse que esta zona intermedia entre las esferas de lo público y lo privado es compartida por muchas de las asociaciones de familiares de desaparecidos que operan en el mundo de lo público definiéndose por un rótulo que es válido más bien para la esfera íntima -hijos, madres, abuelas, hermanos. Así como la recepción de las actividades de estas organizaciones pretende traspasar la esfera micro, de la misma manera estas fotos son recibidas por un público amplio y heterogéneo, en nuestro país y fuera de él.” $(2008$, p. 8).
} 


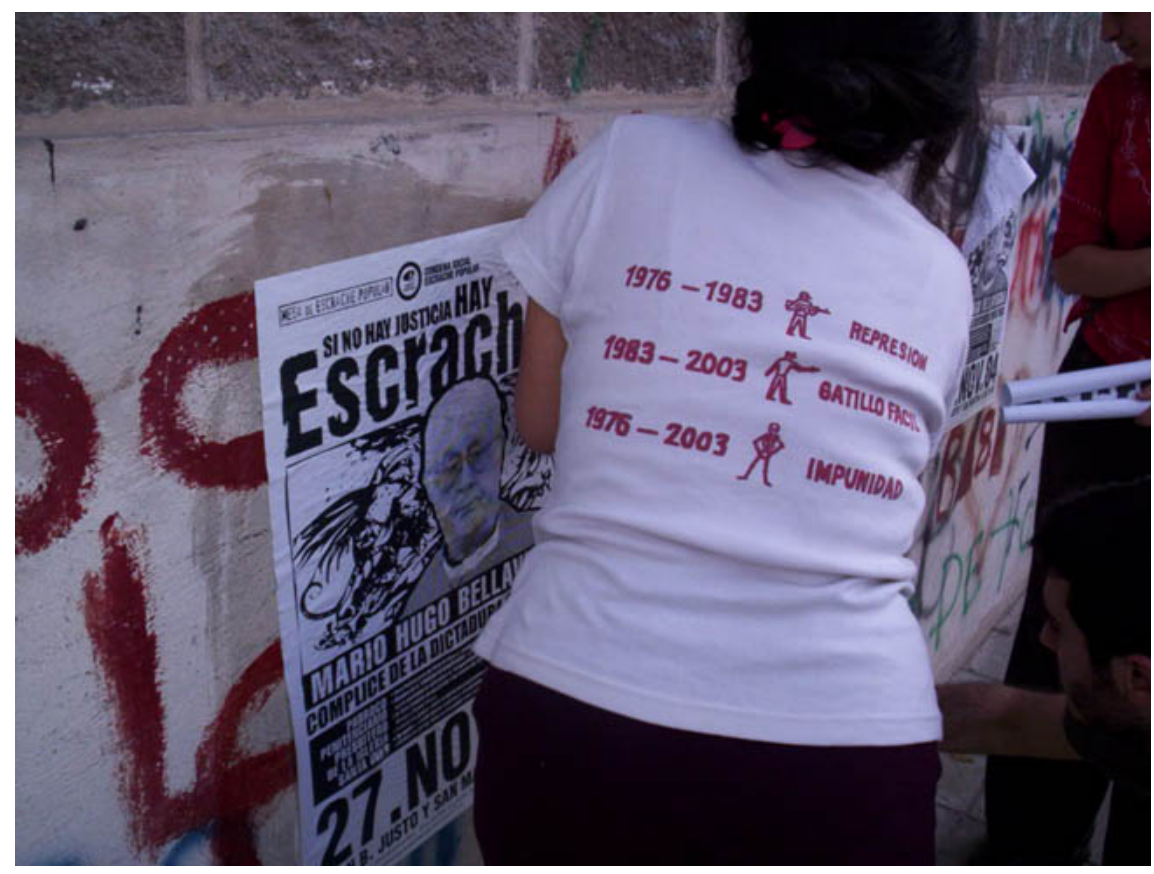

Imagen de la acción del Taller Popular de Serigrafía en el escrache a Mario Hugo Bellavigna, 27 de noviembre de 2004 en CABA. Fotografía de Kelly (Argentina Indymedia, s/p.).

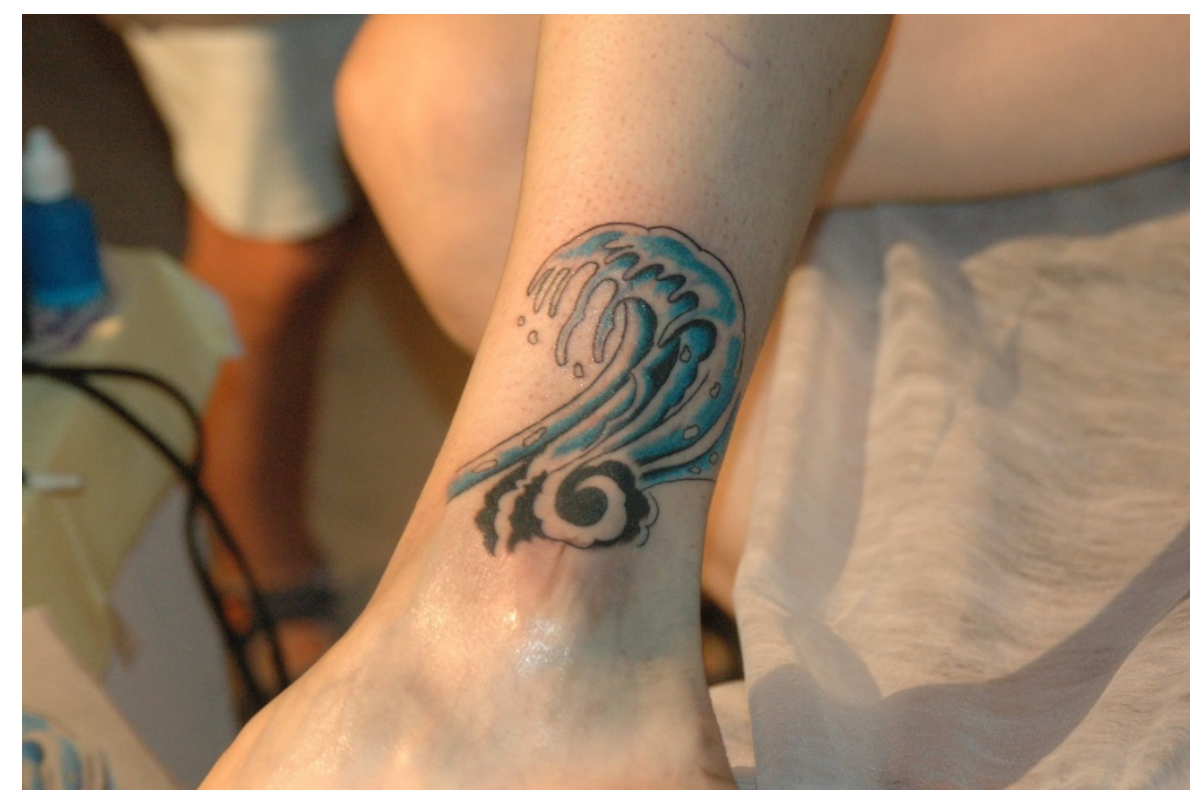

Tatuaje llamado "Purificación" realizado en la performance Tres Bellas Heridas de Soledad Sánchez Goldar, Espacio CePIA, UNC, 2007. 


\section{CAPÍTULO 4. LO CORPORAL Y LA MEMORIA}

El cuerpo ocupa un lugar central al reflexionar sobre las prácticas artísticas pertenecientes a la generación de hijos/as víctimas de la última dictadura cívico-militar argentina. Las acciones performáticas que manifiestan una memoria traumática a través de lo corporal tienen un recorrido particular y notable, especialmente, en las propuestas que se han dado tanto en el marco de los Movimientos de Derechos Humanos en Argentina y en el contexto de las performances artísticas y la resistencia cultural en América Latina. Para introducirnos en estas historias, expondremos en un primer momento algunos ejes teóricos sobre las problemáticas en torno a cuerpo, performance, memoria traumática y acciones artísticas en Argentina y América Latina -intentando destacar las especificidades de lo corporal- y, en un segundo momento, reflexionaremos sobre dos casos en particular de artistas -exiliadas- de la segunda generación: la trayectoria de Magdalena Jitrik en relación al activismo artístico desarrollado por el Taller Popular de Serigrafía (TPS, 2002-2007) -y su participación en la Mesa de Escrache Popular- y la performance Tres Bellas Heridas (2007) de Soledad Sánchez Goldar.

Para poder enmarcar las acciones artísticas abordadas en el capítulo, haremos una distinción entre dos espacios y, por lo tanto, dos miradas de cuerpo diferentes: el espacio público y el espacio privado/íntimo (si bien los dos espacios se cruzan, algunas acciones artísticas tienden más a uno que a otro). La acción performática llevada a cabo por el TPS se trata, en parte, de poner el cuerpo en el espacio público -la calle- y se corresponde con una serie de acciones que emergen de la articulación entre las prácticas estéticas y los activismos, es decir, el denominado activismo artístico. Este es el caso de los colectivos artísticos que trabajan conjuntamente con las asambleas populares, los movimientos de piqueteros y de fábricas recuperadas o los organismos de Derechos Humanos en Argentina. En cambio, Tres Bellas Heridas de Soledad Sánchez Goldar propone una mirada íntima sobre la memoria traumática y el cuerpo. En un espacio cerrado - una sala de exposición- hay un ritual de duelo de un cuerpo íntimo y familiar vehiculizado en las incisiones en la piel -los tatuajes- y las costuras de las telas -se genera un patchwork con fotografías. A partir, entonces, del análisis de estos casos y según lo desarrollado en los capítulos anteriores, veremos cómo muchos de los hijos/as tienen una doble inscripción: pertenecen tanto a movimientos políticos como al circuito 
artístico -con sus correspondientes actores y luchas. No olvidemos que la mirada que sostenemos implica pensar en producciones artísticas en donde forma y contenido son inseparables. No nos referimos a un "arte político" en donde "lo político" es un adjetivo de "lo artístico", o "lo artístico" es un mero reflejo de "lo político". Pensamos, entonces, al arte y la política como divisiones de lo sensible -y no como campos separados-, por lo tanto la dimensión política se encuentra presente en cada propuesta artística: "Más allá de la dimensión estética de lo político y la dimensión política de lo estético, las prácticas artísticas, y fundamentalmente las imágenes, fortalecen un orden hegemónico o lo impugnan con imágenes disidentes, por lo que no podríamos hablar de un arte político y uno apolítico”. (Pérez Balbi, 2012, p. 193).

\section{Cuerpo y performance}

Hay muchas maneras de entender la performance: una acción poética, una práctica corporal, un acto político o económico, o religioso, una forma de analizar procesos, un modo de transmisión son algunos de los usos que tiene el concepto. Sin duda, el cuerpo ha sido el protagonista de la performance y ha estado muy relacionado con el teatro, la improvisación, la danza, el happening, entre otros. Richard Schechner, uno de los principales teóricos del campo de estudios de la performance, diferencia dos grandes miradas en el abordaje de este tema: por un lado podemos analizar una escena del mundo "como performance", es decir bajo el lente metodológico que permite visualizar cualquier evento como performance -desde una obra de teatro, danza o un rito shamánico, hasta una campaña electoral o los roles sociales de la vida cotidiana y comportamientos ligados al género, etnia, ciudadanía, etc.- y, por otro, nos focalizamos en algo que "es" una performance según la convención cultural, es decir en donde se implican comportamientos teatrales, predeterminados, con prácticas definidas y separadas de otras que las rodean ${ }^{87}$.

Desde los años 60 se desarrolla en nuestra cultura las llamadas "artes de la performance", en las cuales se destaca el uso del cuerpo como material en la propuesta artística. Si bien las primeras experiencias comienzan en las vanguardias históricas con el futurismo, el surrealismo, el dadaísmo o el movimiento artístico Fluxus, entre otros,

\footnotetext{
${ }^{87}$ Como explica Taylor, "[e]l performance, pues, es una práctica y una epistemología, una forma de comprender el mundo y un lente metodológico. (...) La demarcación de estos hechos COMO performance se da desde afuera, desde el lente analítico que las constituye como objetos de estudio. La Nación no es un performance, pero se puede analizar como performance en el sentido de la puesta en escena de lo nacional" (2012, p. 31).
} 
se expanden en los años 70 con el arte conceptual, el body art y los happenings, desarrollándose una práctica específica y un campo de estudios en los Estados Unidos.

Schechner (2000) señala que la base teórica que agrupa todas estas prácticas es la cualidad de la "conducta restaurada" o "conducta practicada dos veces", es decir, son conductas repetidas más de una vez: "Ese proceso de repetición, de construcción (ausencia de "originalidad" o "espontaneidad") es la marca distintiva de la performance, sea en las artes, en la vida cotidiana, la ceremonia, el ritual o el juego.” (p. 13). Sin embargo, esta repetición de la conducta conlleva una paradoja, dado que cada instancia es, a su vez, diferente de la anterior. Repetición no significa, entonces, copia. Siguiendo a Diana Taylor, la performance "incluye también la posibilidad de cambio, crítica y creatividad dentro de la repetición" (17). Y, a su vez, repetición no significa tampoco representación:

Representación, aun con su verbo representar, evoca nociones de mímesis, el quiebre platónico entre lo "real" y su "representación", nociones que se han complicado de modo muy productivo a través del término performance. El performance, como acción y como intervención, va más allá de la representación. (p. 43).

En este sentido Marina Abramović, una de las primeras performers artísticas en la década de los 70, insiste en la diferencia entre el teatro y la performance: "En un teatro el cuchillo no es un cuchillo, la sangre es kétchup. En la performance el cuchillo es el cuchillo y la sangre es real. Es una gran diferencia." ${ }^{88}$ Como vimos en el capítulo anterior con respecto a la fotografía, también en estas prácticas hay que tener en cuenta que el par dicotómico verdad/ficción opera conjuntamente en una misma performance, sin que un concepto excluya al otro ${ }^{89}$, como afirma Diana Taylor: "Mientras en algunos casos el énfasis en el aspecto artificial de la performance como "constructo" revela un prejuicio antiteatral, en lecturas más complejas lo construido es reconocido como copartícipe de lo "real" (2012, p. 33).

\footnotetext{
${ }^{88}$ Esta frase la dijo Marina Abramović en varias oportunidades, esta cita fue extraída del encuentro con la artista y Andrea Giunta realizado en la Primera Bienal de Performance 2015 en el Centro de Arte Experimental, UNSAM, Ciudad Autónoma de Buenos Aires.

${ }^{89}$ En la mayoría de las veces el cuerpo mismo del artista es expuesto a situaciones dolorosas o extremas. En esos casos aparece un acto real de violencia o daño sobre el cuerpo. Sin embargo, no hay que perder el marco en la cual se genera dicho acto, es decir, una propuesta poética: "debemos tener en cuenta que el performance, incluso entendido estrictamente como arte en vivo, es siempre intermediado. Los actos funcionan dentro de sistemas de representación, dentro de los cuales el cuerpo es una mediación más, que transmite información y participa en la circulación de imágenes. En este sentido es tanto el medio como el mensaje." (Diana Taylor, 2012, p. 75).
} 
Existe todo un debate en América Latina sobre el uso del término "performance" -debido a su vocablo anglosajón- y, dentro del campo de las artes, aparecen otros términos que se utilizan en sentidos parecidos, como por ejemplo arte vivo, arte-acción o accionismo ${ }^{90}$. Sin embargo, y a pesar de ser una palabra extranjera y de haberse legitimado como campo en Estados Unidos en los '70, este tipo de prácticas están enraizadas en América Latina y han sido portadoras y trasmisoras de distintas memorias colectivas a lo largo de la historia: "Las performance operan como actos en vivo o acciones corporales que trasmiten saberes sociales, memoria y sentido de identidad a partir de acciones o comportamientos reiterados.” (Taylor, 2012, p. 52).

\section{Memorias traumáticas a través del cuerpo y de la performance}

La cuestión política se plantea en las entrañas de la propia poética.

Suely Rolnik

¿Por qué se realiza una performance artística para transmitir una historia familiar marcada por la violencia del terrorismo de estado?, ¿cuál es la relación entre cuerpo y memoria traumática? En este punto intentaremos aproximarnos a las particularidades que presenta este tipo de práctica artística en relación a las memorias que propone vehiculizar la segunda generación. Teniendo en cuenta que las múltiples y complejas relaciones entre cuerpo, memoria y performance exceden el análisis del presente capítulo, haremos, sin embargo, hincapié en algunos temas específicos que nos ayudarán a comprender mejor los casos abordados posteriormente, entre ellos: la relación entre performance y resistencia cultural, lo corporal como materialidad afectada por el terrorismo de estado, la relación entre cuerpo, poética, política y memoria afectiva expresada en términos de micropolítica, y la confluencia de los mecanismos propios del trauma y los de la performance.

Una particularidad del desarrollo propio de la performance artística reside en el carácter de transgresión, provocación, ruptura, y/o resistencia política que ha tenido en

\footnotetext{
${ }^{90}$ El caso de la utilización del término "acción" en lugar de performance lo manifiesta Raúl Zurita de la siguiente manera: (...) "A una dictadura se le oponen acciones, no performances, porque la palabra acción corroe las fronteras entre lo político y el arte. La acción de arte fue entendida directamente como una acción política y el artista que hacía acciones de arte fue entendido como un activista político, sin mediaciones." (Taylor, 2012, p. 38).
} 
su recorrido en nuestro continente y, más específicamente, en el Cono Sur ${ }^{91}$. Irina Garbatzky, en su reciente libro publicado Los ochenta recienvivos. Poesía y performance en el Río de La Plata (2013) sugiere que si bien la performance nace en los años 60 con el retorno de las vanguardias y se enmarca en el "giro conceptual" atendiendo al carácter procesual de la obra y planteándola como acción en lugar de objeto-, en el Cono Sur la performance propone otro corrimiento ligado a la resistencia cultural y a resolver conflictos políticos e identitarios:

Si bien la experiencia de las vanguardias aparece muchas veces omitida e inexplícita en la serie que compone el corpus, funciona como el dispositivo de un tipo de acción vanguardista/poética que en el contexto de la posdictadura no cumple ya con un intento de romper con la cultura, pero sí de resistencia cultural, sobre todo en lo que concernía a los vínculos sociales y expresiones corporales. (p. 13).

Algunas de las manifestaciones de esta resistencia cultural en el Cono Sur $-\mathrm{y}$ que son parte del corpus de análisis de Garbatzky- fueron encabezadas por los performers Marosa di Giorgio, Roberto Echavarren, Colectivo PIRA, Emeterio Cerro, Batato Barea, entre muchos otros. Esto se intensifica incluso más en la Argentina con las personas agrupadas en los Organismos de Derechos Humanos que llevaron a cabo acciones político-poéticas donde pusieron el cuerpo como forma de confrontación con el régimen autoritario -el caso de las Madres de Plaza de Mayo, el Siluetazo y los escraches de H.I.J.O.S, entre otros.

Esta relación estrecha entre performance y resistencia dada en nuestro contexto, se puede desentrañar, en parte, por las potencialidades existentes en el cuerpo como dispositivo de expresión artística. Si bien la performance es efímera, debido a que sucede en un lugar determinado y con una cierta duración, no significa que sea inmaterial: "El punto de vista que quiero proponer para pensar la performance es el de una obra-vivencia, que, estructurada mediante formas de la teatralidad, pone en tensión la desmaterialización del objeto artístico con el anclaje físico, el soporte corporal del performer." (Garbatzky, 2013, p. 14). En este sentido el cuerpo constituye una materialidad muy concreta y, a su vez, marcada, en el caso de los contextos dictatoriales

\footnotetext{
${ }^{91}$ Como afirma Taylor: “(...) una de las características del performance es justamente trasgredir barreras, límites y definiciones. Aun así, el arte de performance tiene sus códigos y convenciones: la convención es romper con las convenciones." (2012, p. 87).
} 
del Cono Sur, por un significado específico ligado al modo de operar de las Fuerzas Armadas. La desaparición forzada de personas en Argentina -y la ausencia de los cuerpos- constituye una marca indeleble para la memoria colectiva. Entonces, en el caso de los performers del Cono Sur, el cuerpo es el mismo cuerpo que se ve afectado por el régimen autoritario. Guattari y Rolnik son quienes plantean la cuestión del cuerpo en términos de "cartografías del deseo", introduciendo en el cuerpo el espacio de los afectos para señalarnos la presencia de una "memoria afectiva":

$\mathrm{Si}$ bien éste [el autoritarismo] se manifiesta más obviamente en la censura contra los productos del proceso de creación, mucho más sutil y nefasto es su impalpable efecto de exhibición de la propia emergencia de este proceso -una amenaza que sobrevuela en el aire debido al trauma inexorable de una violencia por parte del Estado, que puede ir de la prisión a la tortura y llegar incluso a la muerte. Dicha asociación se inscribe en la memoria inmaterial del cuerpo: es la memoria física y afectiva de las sensaciones de dolor, miedo y humillación (distinta aunque indisociable de la memoria de la percepción de las formas y los hechos, con sus respectivas representaciones y las narrativas que las enlazan). El desentrañarla constituye una tarea tan sutil y compleja como el proceso que resultó en su represión (esto puede incluso prolongarse durante trieinta años o más, y plasmarse recién en la segunda o en la tercera generación.). (2013, p. 120).

Suely Rolnik reflexiona en "Furor de archivo" (2008) sobre la forma compulsiva de archivar las experiencias artísticas realizadas en las décadas de 1960 y 1970 y sobre la pérdida de su potencial poético-político en el presente debido, en parte, a la mercantilización del arte. Para abordar estas prácticas propone superar la escisión entre lo político y lo poético, entre el artista y el militante, y pensar que la cuestión política está encarnada en la obra. Rolnik reflexiona, entonces, sobre la categoría de micropolítica propuesta por Félix Guattari ${ }^{92}$ (retomando los estudios de Foucault), para vislumbrar las estrategias de una política del deseo, de la subjetividad y de la relación con el otro en el campo social. Una forma de ver lo "real sensible, invisible e indecible", la experiencia del estado de cosas en el propio cuerpo, como una inscripción inconsciente. Mientras la acción macropolítica es la cara visible del combate por la

\footnotetext{
${ }^{92}$ El libro que compila los estudios de Félix Guattari sobre la micropolítica es: Guattari, Félix y Rolnik, Suely (2013) Micropolitica. Cartografías del deseo.
} 
distribución de lugares establecidos por la cartografía dominante en un determinado contexto social -conflictos de clase, religión, etnia, género, etc.-, lo real visible y decible; la micropolítica "consiste en la tensión de la dinámica paradójica ubicada entre la cartografía dominante, con su relativa estabilidad, de un lado, y la realidad sensible en permanente cambio del otro lado" que afecta a nuestros cuerpos. De esta manera "la acción micropolítica se inscribe en el plano performativo, no solamente artístico (visual, musical, literario u otro), sino también en el conceptual y/o existencial" (pp. 123,124). Asimismo, Leticia Muñoz Cobeñas retoma la idea de experiencia y sentimiento de Raymond Williams para pensar las estructuras del sentir: "La definición de Williams nos acerca a la relación estrecha entre vivir, sentir, y pensar y de qué manera las condiciones sociales/culturales van en procesos, conformando "estructuras del sentir" en un vínculo muy cercano con la noción de experiencia”. (2012, p. 110).

Si a la tensión macropolítica se accede principalmente a través de la percepción; a la micropolítica se accede por la vía de la sensación, abordando la alteridad como fuerza que nos afecta corporalmente, de modo que el otro se torna en una presencia viva que nos produce tensión. Rolnik afirma, entonces, que es esta inquietud la que genera una propuesta artística, o algún tipo de manifestación o modo de existencia. En esta línea de análisis, por lo tanto, el cuerpo propuesto como soporte de una performance es un cuerpo capaz de trasmitir un saber afectivo, es trasportador de una memoria inmaterial, como citamos anteriormente, es, en nuestro contexto, "la memoria física y afectiva de las sensaciones de dolor, miedo y humillación” (2013, p. 120).

Otra especificidad de la performance en relación a su capacidad de vehiculizar memorias traumáticas, reside en su propio proceso de realización. Ya mencionamos cómo, siguiendo a Richard Schechner, la performance es una "conducta practicada dos veces", o conducta restaurada, revivida, reactualizada. Esto significa que una acción, cada vez que se vuelve a realizar, implica atravesar una nueva situación -aunque la performance sea "la misma". Este sistema presenta el mismo proceso que tienen las formas psíquicas de elaborar una memoria traumática, de acuerdo a las categorías que explora LaCapra de acting out y working through o elaboración. Como ya vimos en el capítulo anterior, en el acting out el sujeto revive sus conflictos latentes en el presente con una "sensación de inmediatez aumentada por su rechazo a reconocer su origen y su carácter repetitivo" y en la elaboración el sujeto genera una interpretación por medio de un trabajo psíquico logrando aceptar elementos reprimidos y salirse de las lógicas de repetición. (2008, p. 222). Ambos procesos están imbricados, en tanto en la elaboración 
el sujeto genera una repetición modificada por la interpretación -así es como el sujeto logra liberarse de los mecanismos de repetición. En este sentido, entonces, la puesta en escena de una memoria traumática a través del uso del cuerpo en una performance podría ayudar al proceso de elaboración del trauma o, en palabras de Elizabeth Jelin (2012) a trabajar las memorias dolorosas, como afirma Taylor:

Aunque "performance" no es una (re)acción involuntaria, lo que comparte con el trauma es que también se caracteriza como re-iterado. Performance (igual que memoria, igual que trauma) es siempre una experiencia en el presente. Opera en ambos sentidos, como un trasmisor de la memoria traumática, y a la vez su re-escenificación. (2000, p. 34).

\section{El cuerpo del desparecido en acciones artísticas: antecedentes}

Dentro del Movimiento de Derechos Humanos en Argentina, las Madres han privilegiado el cuerpo como el principal medio de reclamo de verdad y justicia por sus hijos detenidos-desaparecidos. Como mencionamos en el capítulo anterior sobre lo fotográfico, ellas realizaban -y continúan realizando- sus rondas en la Plaza de Mayo en plena dictadura portando en sus torsos las fotografías de los rostros de sus hijos/as y marcando sus cuerpos con los pañuelos blancos en las cabezas. Los símbolos en el cuerpo, el movimiento y el uso estratégico del espacio -tanto la elección del lugar como el caminar en círculo- destacan que las Madres tenían un planteo performativo en su reclamo. Diana Taylor destaca que:

Este rito permite el distanciamiento estético que les ofrece una forma de canalizar su dolor, no negarlo. Por otra parte, la naturaleza ritual y la función restauradora de sus manifestaciones logran atraer mucha de la atención pública que ha sido necesaria para su causa, tanto en el ámbito nacional, como internacionalmente. (...) Por otra parte, la naturaleza 'restauradora' de su acción pública en sí misma fue una forma de re-poner a los 'desaparecidos' dentro de la esfera pública, de hacer visibles sus ausencias. Los 'desaparecidos' re-aparecieron vía la performance. (2000, p. 37). 
Otra de las principales acciones estético-políticas en Argentina en donde el cuerpo es el protagonista en la denuncia del terrorismo de estado fue el conocido Siluetazo. En este caso, tres artistas, Rodolfo Aguerreberry, Julio Flores y Guillermo Kexel, idearon en el año 1982 la propuesta que consistía en la realización de siluetas en papel en tamaño real que representaran los cuerpos de los desaparecidos y exponerlos en la calle, una manera de "presentificar la ausencia". (Longoni, 2010). Como la propuesta de representar física y espacialmente a las víctimas a través de las siluetas requería de mucho trabajo e infraestructura -había que realizar 30 mil siluetas, las cuales ocuparían aproximadamente 30 cuadras-, el proyecto quedó suspendido hasta que un amigo, Envar El Kadri, les propuso llevar la iniciativa a las Madres. Ellas tomaron el proyecto como propio y, como tenían su mirada en la forma de representar los desaparecidos, decidieron, entre otras cosas, que las siluetan no tendrían ni nombres ni fechas, sino que fueran neutras y anónimas; y que no se expondrían en el piso. El 21 de septiembre de 1983 se realizó el primer Siluetazo en el marco de la Tercera Marcha de la Resistencia en Plaza de Mayo. Durante la jornada que duró desde las cuatro de la tarde hasta las tres de la mañana del siguiente día, se produjo un taller espontáneo en donde la gente se apropió del procedimiento -el cual consistía en contornear el cuerpo de una persona sobre el papel. Algunos de los cambios que se produjeron en la jornada con respecto a la idea original, tenía que ver con inscribir las siluetas en situaciones particulares - por ejemplo se realizaron siluetas de embarazadas de perfil llevadas a cabo con un almohadón, de niños y niñas a mano alzada, siluetas de un desaparecido en particular, con el nombre y apellido, etc. No nos detendremos más tiempo en esta performance, sobre la cual se ha estudiado mucho -especialmente en los artículos compilados por Ana Longoni y Gustavo Bruzzone en el libro El Siluetazo (2008)-, pero si destacaremos la importancia del procedimiento en la realización de la silueta, en el sentido que, como afirma Longoni, había que "prestarle el cuerpo al ausente", un especie de ritual en donde la "huella del cuerpo se convierte en la huella de dos cuerpos, del que prestó el cuerpo y del que no está" (p. 10).

Además del Siluetazo $-\mathrm{y}$ de las múltiples siluetadas ${ }^{93}$ que se han realizado luego del primero-, han habido otras acciones en el espacio público que continuaron con esta

\footnotetext{
93 Ana Longoni considera que el sufijo - azo se emparenta con las puebladas a partir del Cordobazo, el Viborazo, el Argentinazo, etc., es decir plantea al Siluetazo como una forma de "acontecimiento histórico excepcional en este cruce entre una iniciativa artística, una multitud dispuesta a poner el cuerpo para llevarla a cabo y para apropiársela y un movimiento social que está en las calles disputándole el espacio público a la dictadura, esa condición excepcional es la que permite hablar de un Siluetazo. Pero no todos
} 
forma de política visual ${ }^{94}$ en las manifestaciones, privilegiando al cuerpo entero o partes del mismo. Ana Longoni menciona las acciones de los exiliados latinoamericanos en Europa, agrupados en la Asociación Internacional de Defensa de los Artistas (AIDA). Entre ellas, en noviembre de 1981, organizaron en París una marcha en donde los manifestantes se vistieron de blanco y negro para visibilizar a los artistas desaparecidos y muertos en Argentina desde 1976. Otra de las acciones consistió en el uso de máscaras blancas para denunciar a los desaparecidos portando su nombre en un cartel $-\mathrm{y}$ posteriormente "La marcha de las máscaras blancas"-. "Déle una mano a los desaparecidos" fue una campaña internacional que consistía en poner la mano sobre un papel para realizar la silueta y escribir un nombre, frase, consigna, etc.

Estas prácticas y muchas otras sentaron un precedente en la forma de accionar de los organismos de Derechos Humanos, no sólo en Argentina, sino también en otros países donde había exiliados políticos. Los cuerpos ausentes de los "desaparecidos" están presentes, como reflexionamos anteriormente, en la memoria afectiva de más de una generación en Argentina. Esto se expresa de manera directa en aquellos que ponen el cuerpo en distintas acciones artístico-políticas. A continuación pasaremos, entonces, a reflexionar sobre las propuestas artísticas de la generación de hijos/as de exiliados políticos. Veremos cómo se articulan muchas de las características ya mencionadas en esta primera parte y cómo, a su vez, se presentan nuevas propuestas vinculadas con las problemáticas y experiencias propias de la segunda generación -atravesada tanto por la militancia de los 70, el terrorismo de estado, las organizaciones de derechos humanos, como, a su vez, por el contexto de lucha social generalizada en Argentina (2000-2002). 


\section{El cuerpo en el activismo artístico del TPS y el cuerpo familiar en Tres Bellas Heridas}

A partir del breve recorrido trazado sobre los ejes cuerpo, memoria traumática y performance artística, nos interesa profundizar en la relación entre las especificidades del dispositivo -corporal- en relación a los casos concretos que analizaremos a continuación: la trayectoria de Magdalena Jitrik en el activismo artístico, puntualmente la experiencia en el Taller Popular de Serigrafía (TPS) -donde aparece el cuerpo en la calle, el cuerpo público y militante- y la performance artística Tres Bellas Heridas de Soledad Sánchez Goldar -donde se expone un cuerpo más íntimo y privado. Algunas de las especificidades que mencionamos sobre el uso del cuerpo en las propuestas artísticas son, por un lado, la presencia de una memoria afectiva relacionada con el terrorismo de estado de la Argentina, la capacidad de generar, por medio de una performance, una "conducta restaurada" en relación a una memoria traumática, la utilización del cuerpo como forma de participación en una resistencia cultural, y, por el otro, la memoria colectiva sobre la representación corporal de los desaparecidos en los primeros años de la posdictadura, en el marco de los movimientos de Derechos Humanos en Argentina y en el exilio político. Desde estos supuestos teóricos, entonces, indagaremos en las propuestas performáticas de los hijos e hijas de exiliados políticos a México. Recordemos que muchos de ellos trabajan sobre el doble trauma padecido: su propia experiencia de la violencia vivenciada en la infancia y la memoria traumática trasmitida en el núcleo familiar- del secuestro, la detención y/o desaparición (muchos de ellos tienen algún familiar que ha sido detenido o que está desaparecido) y, asimismo, han estado exiliados en México en algún período de su infancia. En el presente capítulo abordaremos, entonces, en un primer momento el activismo artístico de Magdalena Jitrik y el caso particular del Taller Popular de Serigrafía en algunos de los escraches de la Mesa de Escrache Popular y, en un segundo momento, la performance Tres Bellas Heridas de Soledad Sánchez Goldar -en relación con otras dos performances: Pensamiento y Correspondencia. 


\section{Los hijos en México entre la militancia y el arte: Magdalena Jitrik y la JAE}

Fue el despertar juvenil sobre nuestra condición en México, porque nosotros no teníamos la culpa de nada, ¿no?

Magdalena Jitrik

Magdalena Jitrik es una artista plástica argentina, nacida en la Ciudad Autónoma de Buenos Aires en 1966. Su historia familiar está fuertemente atravesada por el terrorismo de estado. Su padre, Noé Jitrik, crítico literario y escritor, fue expulsado de la Universidad de Buenos Aires en los años previos a la dictadura cívico-militar argentina y, a raíz de una oferta de trabajo, se trasladó al Distrito Federal en México. En 1974, tras unas amenazas telefónicas, la mamá de Magdalena, Tununa Mercado, decide ir a México junto con sus dos hijos y encontrarse con Noé. Desde octubre de 1975 la familia se exilia -Magdalena tenía 8 años de edad y su hermano 12- y regresan a la Argentina en 1987, a excepción de su hermano que se queda a vivir en México. Magdalena realizó sus estudios artísticos en la Escuela Nacional de Artes Plásticas de la Universidad Nacional Autónoma de México y en la Facultad de Filosofía y Letras de la Universidad de Buenos Aires. Dentro de su amplia y variada producción artística, nos detendremos puntualmente en un proyecto colectivo: el Taller Popular de Serigrafía (TPS). Nos interesa indagar en los caminos trazados tanto en el exilio en México como en su vuelta a la Argentina en el campo de la política y del arte.

Como ya mencionamos en el primer capítulo, durante el exilio político en México, varios adolescentes y jóvenes exiliados comenzaron a vincularse entre sí y a realizar actividades en conjunto en el Distrito Federal. Es así como nace la Juventud Argentina en el Exilio (JAE), conformada en 1981 por un grupo de varias personas, entre ellos Magdalena Jitrik, Fabián Cerejeido, María Inés Roqué, Pablo Funes, Julián Gadano, Francisco Ferreira, Martín Levenson, Isabel y María Maldonado, Santiago Pérez, Ana Tamarit, Mariana y Pablo Calvo, Federico Bonasso, Laura Rey y Paola Stefani. Esta temprana organización (una de las primeras que armó la segunda generación, sino la primera) tenía un espacio propio, diferenciado del de la generación de padres, con una fuerte identidad juvenil y una postura independiente de cualquier otro partido u organización (Yankelevich, 2009). Como afirma Magdalena, la JAE: 
(...) era bien adolescente, con ganas de hacer un camino propio. Tiempo después fue la guerra de las Malvinas, la JAE empezó en el 80, 81, nosotros tuvimos una postura que luego resultó correcta por los pibes de 18 años: basta de sacrificar la juventud. Y también estábamos en contra del servicio militar. $Y$ luego habíamos hecho un porcentaje de las listas de desaparecidos y el 60 por ciento era de jóvenes, o no sé si el 60 pero eran muchísimos menores de 18 años, gente como nosotros, o un poquito más grandes. (...) Hacíamos fiestas y peñas y conciertos. Hicimos una actividad de solidaridad con Nicaragua con otras juventudes, chilena y uruguayas, cosas de esas, manifestaciones frente a la embajada, con los demás organismos y también solos. (Jitrik, 2015, s/p.).

Dentro de esta identidad juvenil aparecen nuevos componentes propios de la segunda generación. Uno de ellos, el que más nos interesa a nosotros, tiene que ver con acercar el arte con la acción política. Si bien la relación entre arte y política tiene un desarrollo extenso en América Latina, iremos viendo cómo dentro de la generación de hijos se da una impronta particular, generando, en años posteriores, una forma de activismo artístico. Esta característica también la encontramos tempranamente en la JAE debido, en parte, a la posibilidad de expresarse a través del arte públicamente en México sin los riesgos que se corrían en la Argentina dictatorial:

(...) en México la inclinación artística es muy grande, son muy fuertes las artes visuales ahí. (...) Entonces yo iba a un colegio con mucho énfasis en lo artístico y mis amigos eran artistas y querían ser artistas y entonces todo eso me influenció. No sé de haber estado aquí si eso hubiera sido igual, ¿no? No sé qué tanto hubiera pasado en tanto que aquí había una dictadura. El contacto hacia el arte era una cosa común en México, no es tan rara como aquí, bueno ya no, pero habría que comparar en la misma época. Aquí era un profesorado en la Pueyrredón. En México había una licenciatura y había varios lugares para estudiarla, por ejemplo dos escuelas muy importantes en la ciudad de México, luego en cada universidad tenía sus artes visuales. Eso fue algo quizás fortuito y por suerte. (Jitrik, 2015, $\mathrm{s} / \mathrm{p}$.$) .$

Magdalena cuenta que en la JAE había otro integrante, Fabián Cerejido -actualmente es artista- con el cual dejaban su impronta más artística en las manifestaciones o protestas, etc.: "[hicimos] una bandera gigantesca que decía algo así como "abajo la dictadura". 
Fue una idea de Fabián y mía de hacer algo muy grande y las letras las dibujó Fabián.” (Jitrik, 2015)

Resulta sumamente importante ver cómo se perfilaba desde las primeras organizaciones adolescentes o juveniles la propia impronta generacional. En este sentido, aparecen dos características principales: el interés por la política y la militancia -que, en muchos casos, podría pensarse como una inclinación generada en el núcleo familiar politizado- y, por otro lado, el distanciamiento en la forma de organizarse políticamente con respecto a sus padres y/o a ciertos organismos de derechos humanos especialmente nos interesan las maneras de incluir la práctica artística como medio de acción política.

Antes de continuar con la trayectoria artística y política de Magdalena, haremos un paréntesis para exponer algunas cuestiones de contexto que nos permitirán enmarcar sus prácticas en clave generacional. En un primer momento, presentaremos el recorrido de H.I.J.O.S. con sus puntos básicos de militancia y, en un segundo momento, nos acercaremos al escrache en su dos etapas: dentro de la Comisión de Escrache de H.I.J.O.S. -que inicia la acción en 1996 y adquiere una visibilidad mediática en 1998-; y dentro de la Mesa de Escrache Popular -actuando especialmente hacia el año 2001.

\section{De la Comisión de Escrache en H.I.J.O.S. a la Mesa de Escrache Popular}

La organización Hijos e Hijas por la Identidad y la Justicia contra el Olvido y el Silencio se conforma a partir de unas primeras reuniones que tienen distintos hijos de víctimas de la última dictadura cívico-militar argentina (1976-1983) entre fines de 1994 y principios de 1995. El 20 de abril de ese año se presentan a la sociedad en la Facultad de Humanidades y Ciencias de la Educación de La Plata (UNLP) y se incorporan nuevos hijos a la regional-La Plata, a su vez que se empiezan a delinear las diferentes regionales -actualmente hay más de una veintena tanto en ciudades argentinas como en el extranjero- que conforman la Red Nacional. Sus "Puntos Básicos"-con sus variaciones en el tiempo- son: "Juicio y Castigo a todos los genocidas y sus cómplices", "nulidad efectiva de las leyes de impunidad", "reivindicamos la lucha de nuestros padres, madres y sus compañeros por un país justo, sin miserias ni exclusiones", "restitución de la identidad de nuestros hermanos apropiados", "libertad a los presos políticos y cese de las persecuciones a los luchadores populares", "no a la llamada teoría de los dos demonios que iguala a un pueblo que resiste con el terrorismo de Estado", 
"independencia institucional y partidaria", "reconstrucción del tejido social destruido por la dictadura", "horizontalidad y voluntad de consenso".

Aunque estos puntos básicos expongan una unificación sobre los posicionamientos en H.I.J.O.S, no es menos cierto que si miramos al interior de la organización y de cada regional en particular, encontraremos una heterogeneidad de opiniones muy marcadas con respecto a cada tema planteado. Algunos de los temas/problemas que se disputan en la organización apuntan, en gran parte, al carácter dual de la misma (Cueto Rúa, 2008): por un lado se conforma como un organismo de Derechos Humanos, inscripto en una narrativa humanitaria y en una historia y modos de hacer asociados a otros organismos del mismo tipo (como Madres, Abuelas y Familiares); y por otro lado, se distancian de esta inscripción a partir de querer ser -en algunos casos- una organización de carácter política y militante más cercana a la forma de lucha de la generación de sus padres, que implica otras formas de accionar que se diferencian de las "memoriosos" y "derechohumanosos" 95 .

Para comprender estas dos intenciones disímiles, describiremos a grandes rasgos algunas de sus particularidades. Adscribir a la narrativa humanitaria ${ }^{96}$ implicaba asumir varios supuestos construidos hasta la década del 90, direccionados a un fin judicial pero extendidos a los demás ámbitos sociales, entre ellos: la construcción del desaparecido como sujeto universal de derecho, que implicaba posicionarlo como víctima "inocente" -en tanto era secuestrado y torturado en los centros clandestinos de detención sin pasar por un proceso judicial- y despolitizarlo, es decir desplazarlo de su trayectoria política; el desarme de la figura de "guerra" para explicar los hechos de la década del 70; y el énfasis en la ilegalidad del terrorismo de estado. Sin embargo, como afirma Cueto Rúa:

\footnotetext{
${ }^{95}$ Santiago Cueto Rúa (2008) explica que el calificativo "memorioso" significa que "la memoria que los HIJOS quieren recuperar tiene menos que ver con el terror estatal que con el período previo que había sido protagonizado por sus padres. (...) Y lo distintivo de HIJOS comenzaba a ser la voluntad de ampliar el periodo que debía ser recortado, para incorporar allí a las experiencias políticas de sus padres, y no sólo el momento en que fueron alcanzados (y transformados en víctimas) por el terror estatal." (pp. 100, 101). El calificativo de "derechohumanoso" "pretende criticar las prácticas de los organismos, estrictamente apegadas a la defensa de los derechos humanos. Por el contrario, los HIJOS pretendieron avanzar en el horizonte de sus prácticas. En ese sentido se entiende su participación, fuerte en 1995, en las luchas estudiantiles por frenar la Ley de Educación Superior que impulsa por entonces el gobierno de Menem. Pero además, existía la intención de tener militancia barrial, más en línea con la que realizaban sus padres que con las típicas de los organismos." (p. 102).

${ }^{96}$ Los H.I.J.O.S recibieron mucha influencia de la presidenta de Madres, Hebe de Bonafini, ya que ella fue como una "guiadora" en la construcción del Organismo de Derechos Humanos, como afirma Cueto Rúa (2008): "En la instancia de conformar un nuevo organismo de derechos humanos el modelo de las Madres actuó como paradigma." (p. 76).
} 
Esto empieza a romperse a mediados de los años noventa, momento en que coincide la emergencia de memorias militantes con el nacimiento de la agrupación que se propone estudiar aquí. Investigar las experiencias de HIJOS permite analizar cómo la narrativa humanitaria conspira contra la emergencia de las voces que recuperen la militancia revolucionaria. (2008, p. 35).

Distintos hijos comienzan a agruparse a fines del 94 como una forma de (re)encontrarse con historias de vida similares, de construir un "nosotros", una "hermandad"; como un espacio, en un principio, de expresión y de contención emocional. Luego, este espacio de contención afectiva va a ir adquiriendo otros objetivos más explícitamente políticos, impulsados, en muchos casos, por la "doble militancia" existente en algunos hijos ${ }^{97}$. Pese a la heterogeneidad de posicionamientos político-ideológicos dentro de cada regional, hay un acuerdo en H.I.J.O.S. en ciertas cuestiones: la asamblea horizontal ${ }^{98}$ como forma de organizarse sin verticalismos, es decir un espacio en donde se discuten los temas hasta llegar a un acuerdo consensuado, sin votación -en caso contrario, la actividad no se realiza-; el autofinanciamiento, para evitar la elección de autoridades que exigen las entidades externas que financian -como en Madres, Abuelas, Familiares.-; la reivindicación de sus padres como actores políticos, reincorporando las experiencias de los militantes de los 70 -aunque no todos los H.I.J.O.S estaban de acuerdo en el componente revolucionario, sino más bien su "espíritu de lucha"99-; trascender las actividades del campo de los Derechos Humanos, para participar en otro tipo de luchas, como por ejemplo los conflictos de los estudiantes universitarios o de los obreros. Estas formas de entender la política constituyen una "novedad" dentro del campo de los Organismos de Derechos Humanos en tanto que perteneciendo a ese mismo campo- quiebran con algunos de los supuestos antes mencionados de la narrativa humanitaria, a la vez que incorporan otros "nuevos"

\footnotetext{
${ }^{97}$ En el caso de la Regional-La Plata, había Hijos que estaban tanto en el organismo H.I.J.O.S como en Quebracho, o en otros casos los Hijos ya tenían experiencia política previa por haber conformado parte de otros Organismos de derechos Humanos como Familiares.

${ }^{98}$ Según algunos de los integrantes de H.I.J.O.S. la elección de organizarse como asamblea horizontal resulta de la pertenencia universitaria y de la militancia estudiantil que muchos de ellos realizaba. Cueto Rúa agrega también que remite a "una suerte de espíritu de época que cuestiona los verticalismos y aboga por formas de organización autónomas y horizontales." (2008, p. 95).

${ }_{99}^{9}$ Hay diferencias entre las regionales respecto a la memoria elaborada de la militancia de los padres, especialmente entre la regional de Córdoba y la de La Plata (conforman los dos polos opuestos, los llamados "legalistas" y los "radicalizados"). En palabras de Cueto Rúa: "De allí que lo distintivo en La Plata sea remarcar el carácter revolucionario de aquella militancia." (2008, p. 105).
} 
propios de $s u$ generación. Hijos se convierten en H.I.J.O.S. ${ }^{100}$ En la misma línea que la JAE, y, en palabras de Luciano Alonso, "frente al lógico envejecimiento de los militantes de las anteriores organizaciones, H.I.J.O.S. apareció como un actor que traía una renovación generacional y portaba una cultura juvenil” (2011, p. 189). A partir de lo expuesto, vamos notando cómo muchas de las características de H.I.J.O.S. constituyen un antecedente en la forma de organización de la práctica política y los colectivos artísticos surgidos en el contexto de movilización social generalizada en Argentina (2000-2002). A continuación nos enfocaremos en la práctica que pasará de ser la forma de accionar más conocida de H.I.J.O.S. a ser una herramienta de las asambleas populares: el escrache.

El escrache es introducido por H.I.J.O.S. en 1996 como una práctica política que denuncia la impunidad de los represores de la última dictadura cívico-militar en el contexto de las "leyes de impunidad" de la presidencia de Carlos Menem. A grandes rasgos, esta práctica consiste en generar una concientización entre los vecinos del barrio acerca de quién es y qué hizo la persona que se quiere escrachar y luego, en una jornada determinada, se realiza una marcha hacia su vivienda y se señaliza simbólicamente la casa $-\mathrm{u}$ otro lugar como el trabajo. Esta práctica tiene dos momentos diferentes: el primero dirigido en mayor medida por la Comisión de Escrache de H.I.J.O.S. -que inicia la acción en 1996 y adquiere una visibilidad mediática en 1998-; y el segundo momento dirigido por la Mesa de Escrache Popular -especialmente hacia el año 2001que integra, además de la comisión de H.I.J.O.S. ${ }^{101}$, a otras organizaciones como colectivos artísticos -el Taller Popular de Serigrafía por ejemplo-, centros de

\footnotetext{
${ }^{100}$ Si profundizamos un poco más, salta a la vista la pregunta que se hace Cueto Rúa: “¿Cómo pueden estos jóvenes exigir justicia al Estado y al mismo tiempo reivindicar la lucha de sus padres cuyo objetivo era destruir ese Estado?” (2008, p. 6) y “¿Cómo logran los HIJOS articular una narrativa humanitaria, propia del campo de los derechos humanos, con una recuperación política de las prácticas revolucionarias de sus padres?" (2008, p. 7). Si bien estas preguntas son centrales al analizar los discursos de H.I.J.O.S, nos interesa no obstante hacer un corrimiento de estos ejes y poner el énfasis en el accionar práctico de la agrupación. En este sentido no apuntamos a analizar tanto las tensiones entre el discurso reivindicativo de la militancia de los 70 y el de la narrativa humanitaria, sino más bien en las prácticas políticas concretas que llevan a cabo H.I.J.O.S y su forma de organización en el marco de protesta social generalizada del período 2000-2002 inclusive.

${ }^{101}$ Otro tema importante dentro de H.I.J.O.S. tiene que ver con la apertura o no de su población: “( ...) cada regional debía discutir quién podría pertenecer al grupo. Se fueron definiendo tres posibilidades. En primer lugar, estaban quienes creían que a la organización debían entrar sólo los hijos de los desaparecidos y asesinados ("dos orígenes"). La segunda postura aceptaba también hijos de exiliados y ex presos políticos ("cuatro orígenes"). En último término estaban los que no querían hacer restricciones al ingreso ("población abierta"). (Cueto Rúa, 2008, p. 64). Uno de los hijos habla de un "dolorómetro" que expresa, como explica Cueto Rúa, "lo que se ponía en juego era la mayor legitimidad para hablar, incluso para pertenecer, de aquellos cuyo sufrimiento había sido indudable e incomparable." (Cueto Rúa, 2008, p. $73)$.
} 
estudiantes, agrupaciones diversas, sindicatos, estudiantes, organismos de derechos humanos, centros culturales, murgas y gente "suelta". Estos dos momentos atravesados por una apertura en la diversidad de los grupos organizadores del escrache (pasa de ser una práctica llevada a cabo por un organismo de derechos humanos a ser una forma de accionar de las asambleas), proponen diferentes miradas sobre el escrache. En este sentido resulta muy interesante confrontar la multiplicidad de textos publicados que aparecen en torno al escrache en uno y otro momento, es decir, antes y después del 2001 (Colectivo Situaciones, 2002) ${ }^{102}$. Algunos temas/ejes que generan distintas miradas sobre esta práctica son: el tipo de justicia que se busca con el escrache -institucional o popular-; la importancia del tiempo presente del escrache -se realiza sobre un dictador que no ha sido juzgado por la justicia institucional y participa en el presente de cargos o funciones estatales; una nueva forma alternativa y "festiva" de relacionar política, arte y memoria -en comparación con las tradicionales marchas-; y el tema de la violencia política y la ilegalidad del escrache.

Entre estos temas mencionados, el que genera más discusión y diferencias entre el Colectivo Situaciones e H.I.J.O.S. es el relacionado con el tipo de justicia que se apunta con el escrache. Una pregunta que dispara los dos posicionamientos diferentes se puede resumir del siguiente modo: ¿el escrache tiene como fin cambiar la justicia de la democracia representativa o busca generar/crear otro tipo de justicia, una justicia popular? Una postura -sostenida mayormente por el Colectivo Situaciones- apunta a que el escrache es un fin en sí mismo, ya que genera una condena social por parte de los vecinos hacia el escrachado, una justicia autónoma, popular. La otra postura -sostenida en un inicio más fuertemente por H.I.J.O.S.- plantea que "si no hay justicia hay escrache. Pero porque no hay justicia hay escrache" (2000, s/p). Es decir, se posiciona ideológicamente a favor de la justicia institucional y apuesta a un futuro democrático en donde los represores se enjuicien y vayan presos. En este sentido, se considera al escrache como una herramienta de movilización social, un medio para cambiar la justicia institucional.

A pesar de que estas dos posturas diferentes generan tensión al interior mismo de H.I.J.O.S. y, a su vez, con el Colectivo Situaciones, nos resulta importante destacar que

\footnotetext{
${ }^{102}$ El Colectivo Situaciones realiza una publicación "Genocida en el barrio: Mesa de Escrache Popular" en octubre del 2002. En ésta se incluye una reedición de su primer cuaderno dedicado a H.I.J.O.S. y los escraches en el año 2000 donde publican varios textos, entre ellos "9 hipótesis para la discusión", un documento escrito por H.I.J.O.S. sobre los escraches. Luego de este texto, se publica una conversación que tuvieron el Colectivo Situaciones con H.I.J.O.S. el 8 de septiembre de 2000 generada a partir de estas 9 hipótesis.
} 
funcionan en la práctica paralelamente. Lejos de excluir, el escrache logra contener a ambos posicionamientos a la vez, como afirma un integrante de H.I.J.O.S.: "Eso quizás puede parecer contradictorio, pero la idea es molestar en todos los planos, hacer lo máximo que se puede en todos lados."(Colectivo Situaciones, 2000, s/p).

En el cuaderno No 5 del Colectivo Situaciones, realizado después del 2001, se ve claramente la nueva etapa del escrache: pasa de estar organizado exclusivamente por H.I.J.O.S a una coordinación que incluye a un conjunto diverso de actores nucleados en la "Mesa de Escrache Popular" y, por lo tanto, se da un cambio de mirada direccionado a considerar el escrache como una forma de acción directa -en esta etapa es donde va a participar en algunos escraches el Taller Popular de Serigrafia integrado por Magdalena Jitrik y que analizaremos más adelante. En uno de los textos publicados titulado "Saberes Situacionales (los escraches) ${ }^{103 "}$ se comienza citando a Horacio González, quien afirma que: "Los escraches son (...) las armas específicas de las asambleas, para bien o para mal. Si algunos saquean y otros piquetean, las asambleas "escrachan"” (2008, s/p.). De esta manera se intensifica mucho más la función del escrache como forma de acción directa -no mediatizada por las instituciones de la democracia representativa- y autónoma de hacer justicia por medio de la condena social. Una forma de justicia popular, en donde se

(...) remueve toda una cadena de complicidades que hicieron posible el genocidio y convoca - para hacer justicia- a miles de personas, particularmente vecinos de los genocidas, que son quienes toman en sus manos la tarea de ejercer la pena. Así el escrachado ya no será "un vecino más". Y a partir de ese momento, "todos" saben quién es, lo que hizo. La pena pasa a manos de los vecinos a partir de un acto simbólico, el escrache. (2000, s/p.).

A partir del breve recorrido que trazamos sobre la Juventud Argentina en el Exilio, los H.I.J.O.S y la Mesa de Escrache Popular podemos ir percibiendo las aproximaciones existentes en la forma de organizarse políticamente $-\mathrm{y}$ su impronta generacional. Profundizaremos, a continuación, sobre el lugar que ocupa lo artístico dentro de estas organizaciones y en los nuevos colectivos surgidos en el marco de la lucha social generalizada (2000-2002), para luego ampliar en tres escraches llevados a

\footnotetext{
${ }^{103}$ Este texto está extraído del libro publicado del Colectivo Situaciones, 19 y 20 Apuntes para el nuevo protagonismo social (2002).
} 
cabo por la Mesa de Escrache Popular y en donde participa el Taller Popular de Serigrafía -integrado por Magdalena Jitrik.

\section{1 y el nuevo ciclo de movilización social: los colectivos artísticos}

La conformación de colectivos artísticos en Argentina se inscribe en un proceso de la historia reciente que articula a los movimientos sociales con el activismo artístico $^{104}$. Como comentamos anteriormente, se concibe a lo artístico y a lo político como divisiones de lo sensible y no como esferas autónomas, en este sentido definimos activismo artístico a aquellos:

(...) modos de producción de formas estéticas y de relacionalidad que anteponen la acción social a la tradicional exigencia de autonomía del arte que es consustancial al pensamiento de la modernidad europea. De esta exigencia de autonomía se deriva la inevitabilidad de una esfera artística separada. El activismo artístico niega de facto esa separación, no exclusivamente en el plano teórico e ideológico, sino en la práctica. (Expósito, Vidal y Vindel, 2013: 43)

Para introducirnos rápidamente en la genealogía local, mencionaremos algunas de las prácticas colectivas que, con sus herramientas artísticas, fueron parte de las luchas sociales. Un antecedente de esto fue Tucumán Arde realizado en 1968 entre artistas porteños y $\operatorname{rosarinos}^{105}$ y el Siluetazo -comentado anteriormente- donde participaron algunos colectivos artísticos como Gas-Tar y Colectivo de Arte Participativo tarifa común (CAPataco). Luego, a mediados de los años 90 -y teniendo presente la insurrección indígena en Chiapas a nivel internacional- la agrupación HIJOS irrumpe en el espacio público con su particular forma de expresión político-artística: los escraches. Con esta organización se relacionan, a su vez, los colectivos Grupo de Arte Callejero (GAC) y Etcétera...

A finales del 2001 se da una crisis generalizada (Svampa, 2013) en la Argentina, tanto económica y financiera -proveniente del modelo neoliberal y de la convertibilidad que reinaban desde la década de los 90 y del llamado "corralito"- como

\footnotetext{
${ }^{104}$ Magdalena Pérez Balbi -citando a varios autores como Ana Longoni, Marcelo Expósito, Brian Holmes, entre otros- retoma la categoría de "activismo artístico" surgida en el dadaísmo alemán de principios de siglo XX, ya que "define producciones y acciones, muchas veces colectivas, que recuperan recursos artísticos con la voluntad de tomar posición e incidir en alguna forma en el territorio de lo político (Longoni, 2009), en lugar de entenderlas como hibridaciones entre campos o adjetivaciones del arte" (2012, p.192).

${ }_{105}$ Ana Longoni y Mariano Mestman han profundizado sobre la articulación entre arte y política en el libro Del Di Tella a "Tucumán Arde" (2008). Buenos Aires: Eudeba.
} 
política y social. Frente a la falta de respuesta a la crisis económica por parte del Estado se da una crisis de legitimidad y de representación ${ }^{106}$ que provocan, en las jornadas de 19 y el 20 de diciembre, el estallido de una multitud heterogénea de manifestantes en la Ciudad de Buenos Aires como epicentro y en el resto del país. Bajo la consigna "que se vayan todos y que no quede ni uno solo" la gente sale a la calle en distintas formas semi-espontáneas: manifestaciones, "cacerolazos" y saqueos. El 20 de diciembre, en medio de duras represiones que terminaron con la muerte de 39 manifestantes en todo el país, Fernando De la Rúa renuncia a la presidencia de la nación y, luego de distintas sucesiones de presidencia por parte Puerta, Rodríguez Saa, Camaño y bajo la Ley de Acefalía, asume Eduardo Duhalde el 2 de enero de 2002.

Si bien el concepto de "crisis" fue el que más trascendió en los medios de comunicación y en la opinión pública, esta lectura eclipsa en cierta medida la mirada sobre estas jornadas de fines de 2001. Si nos corremos de esta interpretación, veremos que también se inicia un nuevo ciclo de movilización social encuadrado en el período 2000-2002 inclusive ${ }^{107}$ y caracterizado por la cooperación y la solidaridad "desde abajo" en las formas de lucha y prácticas políticas ${ }^{108}$. La protesta social generalizada es,

\footnotetext{
${ }^{106}$ La consigna "Que se vayan todos y que no quede ni uno solo" que se expresaba por esos días daba cuenta de la crisis de las formas de representación dominante que, a su vez, remitía a los años 90 "los cuales habrían producido un vaciamiento de la política, visible en la subordinación de la política a la economía, a la reducción misma de la figura de la democracia y al autocentramiento de la clase política. Pero también reenviaba a los años 80 , al fracaso de la promesa democrática. Más simple, la crisis de representación tenía que ver con la reducción y vaciamiento de la política, sucedía porque el régimen democrático era concebido bajo los moldes de la democracia delegativa. Así la contracara de la crisis de representación era expresada por otras figuras de la democracia (democracia directa, democracia deliberativa.) (Svampa, 2013, pp. 24-25).

${ }^{107}$ Esta periodización de las luchas sociales corresponde a la realizada por Gustavo Antón, Julián Rebón, Jorge Cresto y Rodrigo Salgado (2010). Siguiendo a los mismos autores el segundo período (2003-2007) está enmarcado por el proceso de recomposición política y de recuperación económica. La presidencia de Néstor Kirchner (2003-2007) produce rupturas políticas y económico-sociales significativas para con los gobiernos de la década anterior. En este período, ante el nuevo contexto, se produce un cambio en la morfología de las luchas populares: algunos actores tienden a desaparecer como, por ejemplo, las asambleas barriales; otros a desmovilizarse crecientemente como, por ejemplo, los piqueteros; otros resurgen, entre ellos el movimiento obrero y sindical y los movimientos contra la inseguridad o los socioambientales; y el movimiento por los derechos humanos cambia su dinámica de movilización. A su vez, las acciones de lucha se institucionalizan, aunque la acción directa sigue presente para ciertos actores. El último período de la década comienza en el 2008 con un nuevo momento de conflictividad social caracterizado por una ralentización del crecimiento económico y el desarrollo de una crisis política de la alianza en el gobierno. Esta vez, las acciones de lucha y su forma de acción directa provienen de sectores de la burguesía. Entre ellos, el conflicto del campo genera un intenso proceso de autonomización y movilización personificado centralmente por corporaciones con metas regresivas en lo político y lo económico. Se tiende a polarizar las posturas políticas del conflicto en favor o en contra del gobierno nacional.

${ }^{108}$ Svampa reflexiona, en el mismo artículo, sobre las distintas lecturas que se dieron para comprender este nuevo ciclo de movilización social como la de Argentinazo y la de acontecimiento, y destaca que: "Diciembre de 2001 tuvo numerosos significados y una enorme productividad política: implicó un punto
} 
entonces, una de las características principales de este período: hay una emergencia de nuevos movimientos sociales, como la conformación de asambleas barriales, los movimientos de recuperación de fábricas y los de ahorristas bancarios; y el desarrollo de otros movimientos surgidos previamente, como los movimientos de trabajadores desocupados o "piqueteros". A su vez, se desarrolla un proceso de autonomización en la lucha social, visible, por ejemplo, en ejercicio de la acción directa -acciones no mediadas institucionalmente.

En este marco de protesta generalizada (2000-2002) emergieron nuevos colectivos artísticos que se integraron a la lucha social ${ }^{109}$. La experiencia colectiva -el activismo artístico participando de las asambleas populares, los movimientos de fábricas recuperadas, los piquetes, los escraches- abría la posibilidad de pensar formas de producción alternativas a la lógica del capitalismo. De esta manera se abría una nueva forma de lo artístico: “¿Representaba esto una diferencia sustancial, la aparición de algo nuevo, que escapaba a todo aquello que podía deducirse de la tradición o de ese particular contexto?” (Giunta, 2009, p. 27).

Reemplazar el taller por la calle, generar una "colectivización" de la práctica artística -donde se borronea la figura del artista individual y se mezcla el rol del creador con el del espectador-, tener estrategias colaborativas, utilizar materiales preexistentes o reciclar -los artistas ya no contaban con los insumos importados-, insertar el arte en escenarios socialmente conflictivos; son algunas de las características que proponen estos colectivos artísticos. Comparten muchas convicciones y formas de organización, "no sólo por una dinámica de producción basada en consensos, ingreso abierto, funcionamiento en red, búsqueda de autonomía económica, rotación de actividades, aspirar a lograr eficacia política" sino también por:

de inflexión en la historia argentina reciente, la apertura a un nuevo escenario político y el corrimiento del límite de lo posible." (Svampa, 2013, p. 21).

${ }^{109}$ Cfr: "Dos coyunturas son cruciales en la aparición, la multiplicación y la vitalidad de los grupos de arte en la calle viculados a nuevos movimientos sociales surgidos en Argentina de la última década. La primera, a mediados de la década del noventa, es el surgimiento de HIJOS, agrupación que reúne a los hijos de los detenidos-desaparecidos durante la última dictadura. Los comienzos de dos grupos que continúan trabajando, el GAC y Etcétera..., están fuertemente emparentados con la elaboración y realización de los "escraches", la modalidad de acción directa que impulsan los HIJOS para señalar la impunidad de los represores y generar condena social. Tanto la señaléctica urbana del GAC como las performances de Etcétera... quedaron en un principio completamente invisibles para el campo artístico como "acciones de arte", y en cambio proporcionaron identidad y visibilidad social a los escraches. La segunda coyuntura, al calor de la revuelta de diciembre de 2001, incluye a una cantidad notable de grupos de artistas plásticos, cineastas y videastas, poetas, periodistas alternativos, pensadores y activistas sociales, que inventaron nuevas formas de intervención vinculadas a los acontecimientos y movimientos sociales con la expectativa de cambiar la existencia en Argentina: asambleas populares, piquetes, fábricas recuperadas por sus trabajadores, movimientos de desocupados, clubes de trueque, etc." (Longoni, 2007, pp. 32, 33). 
(...) la presencia de un vocabulario común (horizontalidad, autogestión) y por el rechazo a las financiaciones por el grado de condicionamiento que éstas pudieron significar para el propio programa (autofinanciación, fiestas, espacios publicitarios o apoyo de particulares interesados en el proyecto aparecen delineados como opciones para recaudar recursos y garantizar autonomía). (Giunta, 2009, pp. 60, 61).

Muchos de los hijos de desaparecidos y/o exiliados están atravesados por estas transformaciones de las prácticas políticas y artísticas -ya mencionamos cómo la JAE es un antecedente de la temprana organización política de los adolescentes exiliados. En este sentido, Magdalena Jitrik va a ser parte de esta experiencia tanto en su participación en algunos escraches de H.I.J.O.S. en la primera etapa como en La Mesa de Escrache Popular con el colectivo artístico Taller Popular de Serigrafía.

\section{Activismo artístico en la Mesa de Escrache Popular: la participación del TPS}

Ya instalada en Argentina y luego de varias experiencias en el circuito artístico, Magdalena Jitrik empieza a concurrir a la asamblea de San Telmo -una de las tantas asambleas populares que surgieron en el contexto de 2001- y, en marzo del 2002, se organiza una jornada cultural en contra del terrorismo de Estado que llaman "San Telmo tiene memoria”. En esta ocasión Mariela Scafati y Diego Posadas arman un taller de serigrafía como una especie de clase abierta en el espacio público. Poco tiempo después, junto con Magdalena, fundan el Taller Popular de Serigrafía (TPS):

El tema de estampar camisetas era una idea que hace mucho teníamos con Diego y Mariela, por eso yo me integré al equipo de forma inmediata. Pero en esa etapa inicial no se planteó como grupo sino como miembros amigos de la "comisión de cultura" de la asamblea, acudiendo al pedido de "ustedes son los artistas, hagan algo". (Jitrik, 2002, p. 95).

Magdalena comenta en una entrevista que el nombre del grupo aludía al Taller Gráfica Popular de México de los 40: 
(...) como yo había vivido en México quise atribuir a ese país una influencia a la hora de ponerme a hacer grabado político. Pero a decir verdad desconocía la historia del TGP al que yo creía ligado a la Revolución Mexicana cuando es un proyecto mucho posterior, la versión gráfica del muralismo, ambas cosas de las que en realidad el TPS posteriormente se quería distanciar. Le pusimos popular porque era el adjetivo que llevaba el nombre de la asamblea." (Jitrik, 2002, p. 95).

A partir de entonces el grupo empieza a participar de las manifestaciones instalando un taller de serigrafía en el espacio público donde se estampan imágenes sobre lo que se reclama en remeras, banderas, afiches, pecheras, buzos, pañuelos, papel, o distintos soportes que llevan los propios manifestantes. A fines del 2002 se incorporan varios artistas al grupo (Carolina Katz, Karina Granieri, Leo Rocco, Horacio Abram Lujan, Eduardo Arauz, Fernando Brizuela, Catalina León, Guillermo Ueno, Julia Masvernat, Christian Wloch, Verónica di Toro, Pablo Rosales, Juana Neumann y, posteriormente, Daniel Sanjurjo) y se conforma un colectivo autónomo. A su vez, se empiezan a relacionar no sólo con el movimiento asambleario, sino también con el piquetero, sindical, estudiantil, de fábricas recuperadas, de derechos humanos y con diferentes activistas y artistas. Una de las particularidades del grupo fue el trabajo colectivo previo para realizar la imagen de la estampa en la calle llevado a cabo en los “dibujazos": (...) consistía en dibujar durante la reunión, tirar allí las ideas y dibujos, luego alguien escaneaba los fragmentos, que elegíamos entre todos, y armaba el próximo diseño." 110

Dentro de la enorme cantidad de imágenes-acciones realizadas colectivamente en la calle y/o llevadas en el cuerpo en las manifestaciones, nos detendremos en tres ejemplos en los cuales el TPS participó en la Mesa de Escrache Popular: el escrache al médico forense y torturador de la policía bonaerense Jorge Héctor Vidal ${ }^{111}$ (imágenes 1-

\footnotetext{
${ }^{110}$ Sin embargo, es interesante notar cómo, este tipo de horizontalidad, se torna por momentos conflictivo para Magdalena y otros integrantes del TPS: "La producción de imágenes se iba sofisticando, y resultaba conflictiva esta combinación de lo individual con lo colectivo, siempre puede suceder que un dibujo no guste. ¿Cómo hacer para incorporar un mal dibujo, con todo el esfuerzo que significa producirlo en serigrafía? bueno, se puede hacer una ideología "anti arte" por lo tanto que no nos importe, pero aquí se establece para mí el conflicto esencial que padeció el taller y que supongo que todo emprendimiento colectivo conlleva...Yo creo en el arte, (...) No puedo renunciar al arte en otras palabras, y creo que varios en el TPS tampoco, defendíamos la ambición artística de modo tal que un horizontalismo entero fue imposible, al menos respecto a la aportación de imágenes". (Jitrik, 2002, p. 97).

${ }^{111}$ El escrache a Jorge Héctor Vidal se realizó el día sábado 27 de diciembre en el domicilio Robertson 1071, Bajo Flores, Capital Federal. Vidal "está libre por la ley de Obediencia Debida. Se desempeñó como médico y torturador en los Centros Clandestinos de Detención "Pozo de Banfield" y en la Brigada de Investigaciones de San Justo. Prestó colaboración para llevar a cabo la sustracción de menores a las
} 
7), al cura represor Mario Hugo Bellavigna ${ }^{112}$ (imágenes 8 y 9) y al comisario represor Ernesto Sergio Weber ${ }^{113}$ (imágenes 10 y 11). El TPS pone el cuerpo instalando un taller de serigrafía en la calle y hace poner el cuerpo a los manifestantes con las estampas en las remeras, carteles, banderas, etc. con dibujos y consignas como: "1976-1983 represión, 1983-2003 gatillo fácil, 1976-2003 impunidad” (imagen 6), “1976-2004 Hugo Mario Bellavigna. Ayer y siempre cómplice de la tortura" (imagen 9), “Impunidad, gatillo fácil, represión ¡El bajo Flores dice basta!” (imagen 2). El cuerpo aparece, entonces, tanto como portador/soporte de las serigrafías (imágenes 3 y 8), como performer y activista que interviene las paredes de la calle pagando carteles (imágenes 1, 2, 4, 5, 6 y 10). A su vez, es un cuerpo colectivo que integra a los productores -en este caso del Taller Popular de Serigrafía- junto con todas las personas que participan del escrache. Estamos, entonces, frente a una manifestación social que tiene un carácter performático (Schechner, 2000):

Con la participación del Grupo de Arte Callejero y de Etcétera (colectivos artísticos que formaron parte de esta construcción desde un principio), la señal como imagen y las performance artísticas fueron parte fundamental del devenir del escrache y se multiplican articulando relaciones complejas entre política, arte, militancia y comunicación. (...) El TPS aportó su imagen-acción en varias ocasiones. (Granieri y Katz, 2010, s/p.).

Como vimos anteriormente, este activismo artístico plantea lo corporal performático como resistencia cultural (Garbatzky, 2013) -como en el caso de las Madres y del Siluetazo-, con todo lo que eso implica en la memoria afectiva de la Argentina: poner el cuerpo en un escrache a un represor implica enfrentarse a la memoria traumática, el miedo y la censura soterrada de la época de la dictadura que

detenidas-desaparecidas que daban a luz en esos centros y falsificó certificados de nacimiento, delitos por los que estuvo detenido tan solo 6 meses. Subcomisario Forense que en 1996 trabajaba en el Depto. De Sanidad de La Plata y se desempeñaba en la Dir. De Ecología y Medio ambiente en la Municipalidad de La Matanza. Nunca fue dado de baja de la Policía Bonaerense" (Blog de la Mesa de Escrache Popular, http://mesadeescrache.blogspot.com.ar/).

${ }_{112}$ El escrache a Mario Hugo Bellavigna se realizó el sábado 27 de noviembre. Se comenzó la movilización desde la Avenida San Martín y Juan B. Justo hasta la Iglesia Santa Inés, en Ávalos 250 del barrio La Paternal donde el cura ofrece misa desde hace ocho años. Bellavigna estuvo entre 1978 y 1982 como cura penitenciario en el Penal de mujeres de Devoto, donde torturaba psicológicamente a las detenidas y evaluaba su "grado de recuperación" desde la Comisión Interdisciplinaria, bajo las órdenes del Teniente Coronel Sánchez Toranzo y el General Suárez Mason.

${ }^{113}$ El escrache al Comisario Ernesto Sergio Weber se realizó el 17 de diciembre en la puerta de la seccional 27. Weber es el responsable de tres asesinatos -Carlos Almirón, Diego Lamagna y Gastón Rivaen la pueblada del 20 de diciembre de 2001 en Plaza de Mayo cuando era jefe del $2^{\circ}$ Cuerpo de Operaciones Federales y Subcomisario de la seccional $1^{\circ}$. 
marcó varias generaciones (Rolnik, 2008) y apropiarse del espacio público como lugar de lucha social y manifestación. A su vez, este tipo de resistencia cultural tiene sus propias características por estar atravesadas, en parte, por el contexto de lucha social generalizada (2000-2002): se busca la acción directa y la justicia popular proponiendo un activismo artístico -donde arte y praxis política son inseparables. Esto genera una representación simbólica con marcas bien distintivas en la jornada del escrache: se simboliza con pintura la casa/trabajo del represor, se realizan obras teatrales o performance artísticas, se canta un cancionero especial para el escrache, se hacen grafitis, sténcil, pintadas, se colocan carteles (especialmente del colectivo Grupo de Arte Callejero) se serigrafían remeras -desde el TPS-, banderas, pegatinas, etc.

Ya vimos cómo Magdalena - con su cercanía familiar a la política, su experiencia de militancia en la JAE y su apertura al mundo de las artes en el exiliointerviene activamente en modos de pensar la militancia artística: participa individualmente en algunos escraches de H.I.J.O.S en los 90, conforma junto a dos compañeros y en el contexto de la asamblea de San Telmo el colectivo artístico Taller Popular de Serigrafía, y participa, con el mismo colectivo, en la Mesa de Escrache Popular. A partir, entonces, del recorrido llevado a cabo por Magdalena Jitrik se puede trazar una continuidad en la red de prácticas que integran el Taller Popular de Serigrafía, H.I.J.O.S. y la Mesa de Escrache Popular. En todas estas prácticas se percibe como trasfondo modos de operar y pensar que están ligados - tanto por cercanía como por distanciamiento- a la generación de detenidos-desaparecidos y/o exiliados de los años 70, a los Organismos de Derechos Humanos, al contexto propio de lucha generalizada del período 2000-2002 y al activismo artístico. Todas estas redes están implicadas y relacionadas a la hora de poner el cuerpo en el espacio público -simbólica y literalmente- en los escraches a Vidal, Bellavigna, Weber y muchas otras prácticas que llevó a cabo el Taller Popular de Serigrafía.

\section{Cuerpo íntimo y familiar en Tres Bellas Heridas de Soledad Sánchez Goldar}

En este capítulo presentamos otra serie de producciones de Soledad Sánchez Goldar $^{114}$ que se relaciona con su memoria familiar traumática y en donde el cuerpo

\footnotetext{
${ }^{114}$ Recordemos que Soledad Sánchez Goldar es una artista argentina con una historia familiar fuertemente afectada por el terrorismo de estado. En 1977 vive sus dos primeros años en México junto a sus padres, exiliados políticos de la última dictadura cívico-militar argentina (Juan José Sánchez, el padre de Soledad,
} 
adquiere un lugar central: en primer lugar la performance Tres Bellas Heridas y, en segundo y tercer lugar, las performances Pensamiento y Correspondencia.

Tres Bellas Heridas es una performance que fue presentada en el Espacio CePIA como trabajo final de la Licenciatura de Teatro de la Universidad Nacional de Córdoba, en el $2007^{115}$. El proyecto consistió en mostrar en una sala varias situaciones a la vez. Por un lado se encontraba Rodolfo Fisher que tatuaba la piel a Soledad en una camilla, con toda la maquinaria e instrumental necesario (imágenes 12 y 13). Esta acción duró tres días y se llevaron a cabo tres tatuajes - uno por día- en distintas partes del cuerpo, llamados Exhalación, Purificación y Deseo. Esta situación, a su vez, estaba acompañada de dos pantallas con videos, uno transmitido en una televisión que mostraba la acción de tatuar con agujas y tinta sobre la piel desde distintos ángulos de la misma y otra pantalla más grande en la cual se proyectaban videos (imagen 14). Por otro lado, generando una segunda acción, estaba la hermana de Soledad, Celeste Sánchez Goldar, cosiendo con una máquina Singer retazos de telas bordadas para construir un quilt o patchwork, una manta bordada conteniendo historias familiares y realizada de forma colectiva (imágenes 21-25). ${ }^{116}$

A partir de esta breve descripción, podemos encontrar en la performance tres instancias -no temporales, sino lógicas- diferentes y conectadas entre sí: la principal es la acción de tatuarse su piel, donde aparece el momento más privado asociado a una forma de ritual de pertenencia y duelo personal; una segunda instancia se puede encontrar en el quilt que arman en un contexto familiar e intrageneracional: y la última donde se plantea la filiación inter/trans generacional en el espacio de exposición pública del proyecto.

En la primera instancia, los tatuajes, las tres bellas heridas, están relacionados con la historia familiar de Soledad (imágenes 17 a 20): el primero llamado Exhalación

estuvo secuestrado y sus tíos Alejandro y Eduardo Goldar Parodi, hermanos de su mamá, son detenidos desaparecidos).

115 Tres Bellas Heridas, 2007, Espacio CePIA, Universidad Nacional de Córdoba. Asistencia: Celeste Sánchez Goldar. Diseño de espacio: Soledad Sánchez Goldar, Esteban Rizzi. Diseño de iluminación: Esteban Rizzi Ropa: Cuqui Diseños. Realización de tatuajes: Rodolfo Fisher. Asistente de montaje: Carolina Vergara. Operación de video: Carolina Vergara. Performers: Soledad y Celeste Sánchez Goldar. Diseño de quilt, María Angélica Goldar Parodi, Juan Cruz, Nahuel, Celeste y Soledad Sánchez Goldar. Producción: Soledad Sánchez Goldar, María Angélica Goldar Parodi. Diseño Gráfico: Digitart. Juan José Estevez. Video: Soledad Sánchez Goldar y documentos de performances anteriores. Fotos: Carmen Cachin.

${ }^{116}$ Esta performance nuclea varios trabajos de Soledad: tanto los realizados anteriormente, Un ala para volar (2006), Beatriz (2005, 2006), Fotos lavadas (2006, 2007, 2008), Sobre los acontecimientos (2007), como los que surgieron a partir de ésta como por ejemplo Correspondencias $(2008,2009,2010)$ y Pensamiento (2010). 
es un dibujo de las flores de cerezo y del viento que representan, en palabras de Soledad "belleza y muerte" (página web, s/p.); Deseo es un homenaje a su tío Alejandro Goldar Parodi, (detenido-desaparecido), y representa un ala que se relaciona con una acción realizada anteriormente Un ala para volar - un altar que se vincula con los discos de vinilo que escuchaba su tío-, y Purificación, representa una ola y tiene relación con la performance Beatriz - en donde Soledad le lava con agua con sal los pies a su abuela como una suerte de ritual en donde se homenajea el caminar de las Madres y Abuelas de Plaza de Mayo.

Retomando lo planteado por Guattari y Rolnik sobre micropolítica y memoria afectiva, podemos pensar estos tatuajes como una forma de hacer aparecer visualmente -y por medio de una técnica hiriente- el cuerpo afectado por el terrorismo de estado, es decir, una forma de materializar lo "real sensible, invisible e indecible", aquello inmaterial del cuerpo como pueden ser "la memoria física y afectiva de las sensaciones de dolor, miedo y humillación" (2013, p. 120). Entonces, a través del tatuaje se explicita esta memoria corporal, $\mathrm{y}$, a su vez, se reafirma esta pertenencia a una historia familiar que ha sido atravesada por la violencia del terrorismo de estado. En este caso como en muchos otros, el tatuaje al ser una inscripción hiriente en el cuerpo establece una marca de identidad y una filiación con la historia familiar.

Pero además, como menciona Marianne Hirsch (1996), los/as hijos/as de padres que vivieron hechos traumáticos tienen una relación ambivalente con la memoria: por un lado experimentan un fuerte impulso de deseo por conocer ese otro mundo que a veces precedió a su nacimiento, o a veces lo vivieron desde muy pequeños en el caso argentino, pero por otro lado hay una pulsión más fuerte de querer re-construir, reencarnar y reparar ese dolor, generando un acto tanto de recuerdo como de duelo. Esta doble dimensión se representa en cada tatuaje que Soledad se graba: por un lado encarna a través de sus imágenes "bellas" -no olvidemos que cada tatuaje representa visualmente la contracara del sufrimiento- tanto la historia de su tío, su abuela o el exilio vivido; y, por el otro, explicita el dolor generado por el terrorismo de estado simbolizado en la herida del propio tatuaje. Esto queda evidenciado cuando habla de sus marcas corporales:

Hablo de Heridas en mi propio trabajo ya que considero que los tatuajes son una intervención dolorosa en mi cuerpo, mi piel violentada por las agujas que penetran para depositar la tinta debajo de la piel, el resultado es estético, 
pero no vacío, cada tatuaje contiene un sentido y una historia particular, son el resultado de un trabajo de análisis personal, de una revisión de la historia que construyó mi actual presente, es una forma de dejar por sentado en mi cuerpo mi paso por esta vida, al igual que cuando se tiene una caída y uno lastima sus rodillas quedan marcas, cicatrices que nos recuerdan ese momento particular. (Sánchez Goldar, 2008, s/p.).

En la segunda instancia Soledad genera un trabajo de duelo en el interior de su familia. Para hacer el quilt o patchwork - una gran tela construida de retazos - convoca a sus familiares a ver fotos y a reconstruir la historia colectiva de sus familias materna y paterna. Este duelo pasa de ser algo individual que sólo Soledad marca en su cuerpo a ser un duelo privado pero a nivel familiar por medio, no del tatuaje, sino de la costura de las distintas telas intervenidas con fotos y textos (imágenes 16, 22-26). Las agujas de la máquina perforan la tela al igual que las agujas perforan su piel. Además dentro de la performance Tres Bellas Heridas, la que hace la costura en la tela con la máquina Singer es su hermana, al mismo tiempo que Soledad se tatúa, generando una comunicación sonora, visual y conceptual entre ambas situaciones. Esta relación queda establecida de manera explícita cuando Soledad cita en el video "Sobre los acontecimientos" 117 a la artista Louise Borgeois:

Cuando era pequeña, todas las mujeres de mi casa usaban agujas. Siempre he sentido fascinación por las agujas, por el poder mágico de las agujas (...) Las agujas sirven para reparar los daños. Tratan de conseguir un tipo de perdón. No son nunca agresivas, a diferencia de los alfileres. (Sánchez Goldar, 2007, s/p.).

De esta manera Soledad extiende su duelo individual a uno de carácter familiar, incluyendo a distintos integrantes de la familia a participar en una performance artística colectiva, -a ser en cierta forma co-autores- como una manera de transformar el dolor en acción: “(...) Celeste intervendrá en la tela, con una aguja, unirá partes de historia unas con otras, y ambas máquinas, la de coser (de mi bis abuela materna, María Valle) y la de tatuar producen un sonido repetitivo que hasta puede llegar a ser violento, de esa violencia y de esas perforaciones surgirán imágenes bellas, pienso que a veces en el dolor y en la oscuridad puede nacer belleza".

$\overline{{ }^{117} \text { Ver video, recuperado de: www.youtube.com/watch? } \mathrm{v}=\mathrm{cfbVfLfc} 0 \mathrm{ZE}}$ 
Hasta estos dos primeros momentos de Tres Bellas Heridas se puede ver el carácter de ritual de duelo como una forma de sanación y de "reparación", en cierto sentido, de ese dolor al interior de la familia y para ella misma. Como mencionamos anteriormente, en la performance la conducta se actualiza en cada repetición, posibilitando simbólicamente la elaboración del trauma. Del sonido repetitivo de las perforaciones que realizan la máquina de tatuar y la máquina de coser surgen nuevas representaciones, las "bellas heridas" que simbolizan y elaboran el trauma familiar.

Esto cambia en la tercera instancia en la cual se establece un diálogo inter/intra generacional, en donde se transmite la memoria heredada, común a la generación de hijos/as (afectados/as directamente en el seno familiar) a aquellos que pertenecen al mismo contexto histórico pero que no han sido afectados de forma directa. De esta manera, Soledad al mostrar estas acciones en un espacio público y frente a distintos espectadores, expande el círculo (pos)memorial. Esto mismo aparece de forma explícita, no sólo con el espacio de exhibición de la institución, sino también en forma simbólica por la utilización de distintos aparatos mediáticos que aparecen en escena, como la televisión y la proyección.

Otra forma de trasmitir esta memoria traumática a los espectadores es a través de las fotografías utilizadas en el patchwork de la performance (se encuentran sobre la mesa de Celeste mientras ella hace las costuras con la máquina). Retomando las reflexiones planteadas en el tercer capítulo sobre fotografía y memoria, citamos a Marianne Hirsch quien destaca que las fotografías cumplen un rol central en el ejercicio de la (pos)memoria ya que, por convencionalismo, "la fotografía familiar otorga un espacio de identificación para cualquier espectador que participa en las convenciones de la representación familiar; así como crea un puente en la abertura entre espectadores que están conectados personalmente al evento y aquellos que no lo están. Estas expanden el círculo posmemorial.”(Hirsch, 1996, p. 668). Estas fotografías tienen una doble dimensión: por un lado muestran rostros particularizados, lugares privados, íntimos y cotidianos, que sólo Soledad y su familia pueden reconocer y establecer las relaciones entre las personas y sus historias de vida, identidades y conocimientos diversos por pertenecer al entorno familiar. Por otro lado las fotografías cumplen ciertos patrones pertenecientes al "álbum familiar" (imagen 26) que logran que el espectador se involucre y establezca una relación con sus propias fotografías familiares, confiriendo una carga emocional a las fotografias de Soledad. 
Por último, presentaremos brevemente otras dos performances en donde se vehiculiza una historia familiar atravesada por el terrorismo de estado: Pensamiento y Correspondencia.

Pensamiento consistió en la realización de un tatuaje con una imagen de una flor en la pierna de Soledad en una sala en el marco del encuentro de Arte acción Desconexiones, realizado en 2010 en la Galería Interferencial en el Distrito Federal, México (imágenes 27-30) ${ }^{118}$. Al igual que en Tres Bellas Heridas aparece el dolor y la elaboración del duelo personal expresado por medio de las agujas incidiendo sobre el cuerpo al realizarse un tatuaje de una flor (imágenes 30 y 31). Sin embargo, a diferencia de la acción anterior, aparece en la performance la asociación directa a una experiencia vivenciada por Soledad durante su infancia y preadolescencia: el exilio político a México. Esta asociación aparece explícita en unas frases escritas en el suelo del espacio donde se realiza la performance (imagen 30):

Abrí los ojos. Aprendí a caminar. Aprendí a decir mamá. Aprendí a decir puta. Nació mi hermana Celeste. Aquí. Pensamiento: flor de los recuerdos. (Sánchez Goldar, página web, 2010, s/p.).

Si bien la segunda generación vivenció, en muchos casos, en forma directa el destierro, no debemos olvidar que fue durante su infancia y que, por lo tanto, generó otras formas de relacionarse con la cultura extranjera. Como mencionamos en el primer capítulo, una de las diferencias de estos/as hijos/as con respecto a sus padres, es que muchas veces asumieron el rol de mediadores entre la cultura mexicana y la argentina portadores de las costumbres mexicanas vivenciadas en el jardín o en la escuela, llevadas al interior de la familia argentina. Si bien en este caso Soledad era muy chiquita cuando estuvo en México como para auspiciar de mediadora entre culturas, no obstante México representa la contracara del destierro, es decir, un lugar, un hogar, en donde nació su hermana y aprendió a decir las primeras palabras: "Hay allí una hermosa unión, un deseo de siempre volver, de estar relacionada con ese hermoso, adorado, bello país" (Sánchez Goldar, página web, s/p.). Acá aparece, como vimos en el primer capítulo, algo similar a lo condensado en la palabra argenmex, en el sentido de que se destaca, en

\footnotetext{
118 2010, Desconexiones, encuentro de Arte acción realizado en la Galería Interferencial, México DF. Fotos: Fernanda Mejía, Miguel Sepúlveda. Diseño y realización del tatuaje: Roxi http://www.myspace.com/roxitattoo
} 
estas palabras, lo positivo de la experiencia de exilio, como huella corporal de la situación atravesada y reconvertida. Para muchos hijos/as haber vivido en México en esa etapa de la vida los marcó identitariamente, los conformó -a diferencia de sus padres- en "sapo de otro pozo" o en argenmex. Más allá de que Soledad sienta o no que es un poco mexicana, sin duda el tatuaje en su cuerpo pasa a formar parte de su construcción identitaria, de su pertenencia y su "deseo de siempre volver" a ese país refugio. En este caso, entonces el tatuaje en la piel condensa de forma anacrónica varias situaciones a la vez -y varios tiempos heterogéneos retomando a Didi-Huberman-: la propia experiencia corporal del exilio, la experiencia familiar y, a su vez, la situación posterior de realizarse un tatuaje en tierras mexicanas.

Por último, Correspondencia es una performance de Soledad Sánchez Goldar realizada junto con el músico Andrés Asia que consistió en bordar sobre la tela de un traje de su papá algunas de las frases de las cartas que enviaron sus padres en el exilio (imágenes 31-33). Hay muchas variantes de esta performance que se fueron desarrollando en distintos momentos, desde el 2008 al 2010. A su vez, en las performances participaron María Angélica Goldar Parodi (mamá de Soledad y Celeste) a través de su voz con la lectura de las cartas y Celeste, su hermana, bordando junto a Soledad y a otras mujeres. ${ }^{119} \mathrm{Si}$ bien el cuerpo de Soledad no aparece como protagonista, como la portadora de los tatuajes, es su cuerpo el que ejerce una suerte de "tatuajes" de algunas frases de las cartas sobre el traje del padre. Nos resulta importante destacar en esta acción que las cartas tienen el valor de documento, de testimonio del exilio, son cartas que han viajado de México a Argentina durante los años de dictadura cívico-militar argentina. Este valor testimonial se encuentra realzado con la presencia de una valija abierta mientras se realiza la acción.

En estas acciones aparecen algunas constantes que nos ayudan a pensar en las particularidades de las producciones artísticas de Soledad y también, quizás, de la segunda generación. Aparece el cuerpo con su doble dimensión poética-testimonial, reforzando lo testimonial -el hecho de ser un cuerpo doliente, de haber sufrido el exilio político y las situaciones familiares traumáticas- a partir de los tatuajes con su dimensión poética. A través de las imágenes se señala el cuerpo, se lo marca, se lo

\footnotetext{
${ }^{119}$ Correspondencia en el Archivo Provincial de la Memoria, Córdoba, Argentina, 22 de marzo de 2010. Mujeres bordando: Carolina Vergara, Rosa Noto, Graciela de Oliveira, Vivie Gandra, Mara Paz. Lectora de cartas: mamá de Soledad. Edición del sonido: Andrés Asia. Documentación: Enrique Javier Díaz. Fotos: Sandra Siviero. Audio de la acción, recuperado de: http://www.myspace.com/mariposasenlapanza
} 
convierte en un territorio lleno de memoria explícita relacionada tanto con el sufrimiento ocasionado por la dictadura cívico-militar como por su contracara, es decir, las experiencias resurgidas del dolor, el exilio como espacio donde se puede continuar con la vida. Otra constante en estos trabajos es la presencia real, física, de sus familiares. Como ya mencionamos en estas acciones -y otras- aparece su hermana Celeste, su mamá María Angélica, su abuela Beatriz, su papá a través del traje. Aparece, así, un cuerpo familiar, una memoria familiar íntima, aquella que no logra transmitirse a través de una lengua neutra, científica, distanciada, objetiva, sino la que se vehiculiza en el seno familiar a través de las expresiones, de los gestos, los olores. Es una memoria que, a su vez, necesita de un duelo familiar para sanar. En este sentido Soledad no se conforma sólo con elaborar el dolor en su cuerpo individual, sino que integra en una misma acción a distintos familiares, conviertiéndolos a su vez, muchas veces, en coautores de la obra. Dentro de este cuerpo familiar, aparece, entonces, con un lugar central el tatuaje como elaborador del trauma en su doble dimensión: hiriente y sanador.

Ambos cuerpos, tanto el público y militante propuesto por Magdalena Jitrik en el Taller Popular de Serigrafía como el íntimo y familiar de Tres Bellas Heridas de Soledad Sánchez Goldar, trabajan las memorias afectadas por el terrorismo de estado ya sean las memorias traumáticas como la cara positiva de la experiencia del exilio- y elaboran el presente. Por un lado tenemos el cuerpo en la calle del TPS, cuerpo militante que crea las imágenes en los escraches y "soporta" las remeras, banderas, sténcil, carteles -emparentados con el cuerpo de las Madres. Por otro lado, está el cuerpo de Soledad que es expuesto y trabajado -los tatuajes- en su materialidad misma, es decir, funciona como soporte y material artístico al mismo tiempo. Podemos destacar que tanto Magdalena como Soledad, además de tener las herencias -transformadas- de la generación de los militantes de los años 70, las memorias trasmitidas en el seno familiar de la dictadura y las influencias de los Organismos de Derechos Humanos -Madres, Abuelas, Familiares-; elaboran sus propuestas artísticas con su propia experiencia generacional tanto del exilio político, de la temprana organización política (en la JAE e H.I.J.O.S.) como las vivencias en el contexto propio de lucha generalizada en Argentina (2000-2002). 


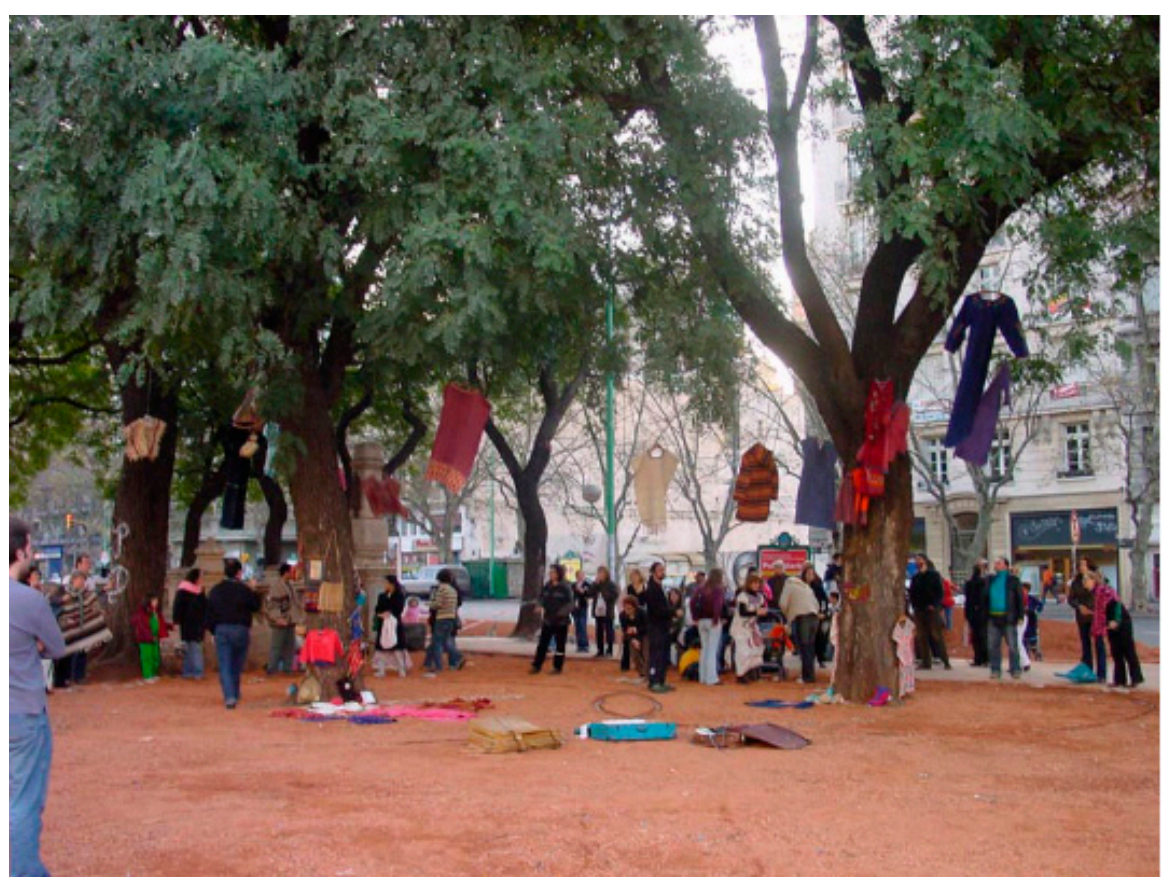

Imagen de la intervención urbana Árbol del desexilio de Mercedes Fidanza, Plaza de los dos congresos, CABA, 2006.

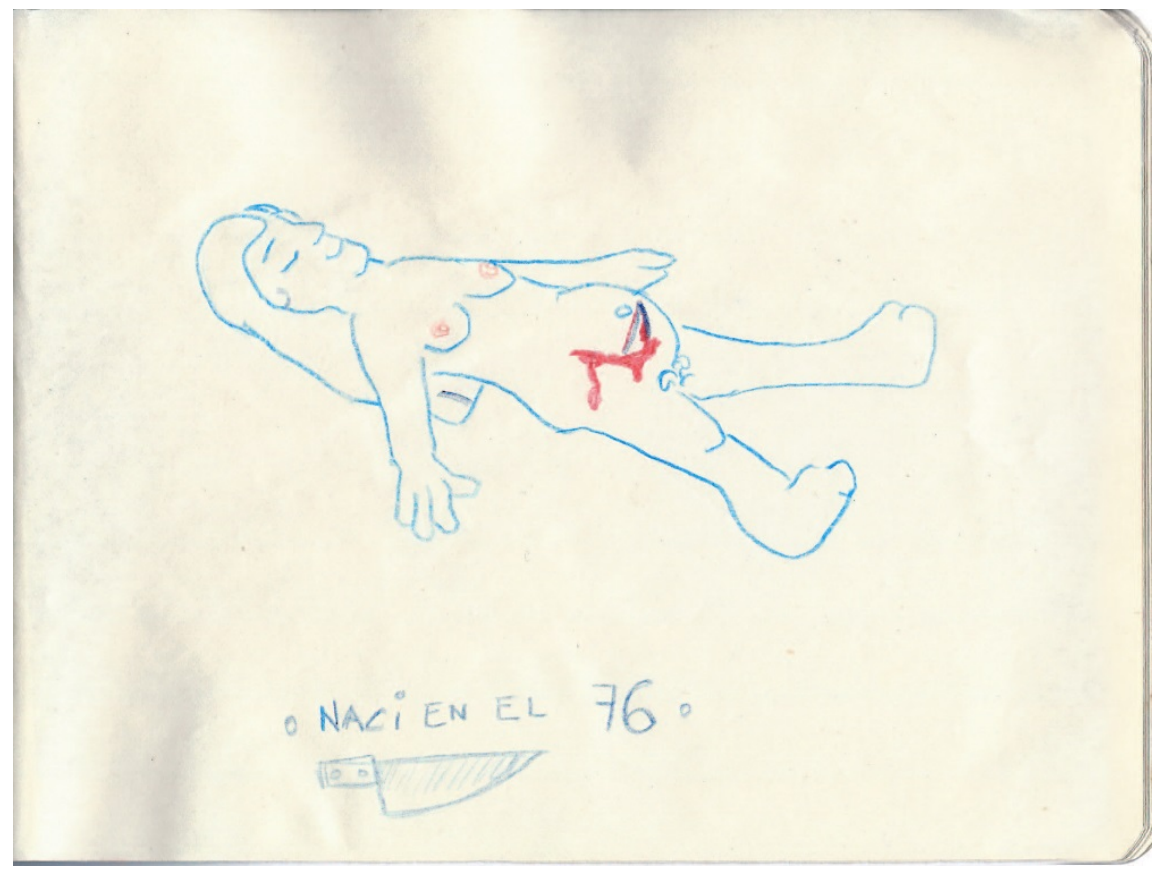

Imagen extraída del cuaderno Un niño de 30 años (2006) de Tomás Alzogaray. 


\section{CAPÍTULO 5. LO OBJETUAL Y LA MEMORIA}

Tanto los objetos del "irse con lo puesto" de los exiliados políticos como aquellos con los que volvieron al país de origen y rememoran al país receptor, cristalizan algunas de las memorias colectivas del destierro -ya que por ser pequeños y livianos han acompañado las valijas de la primera y segunda generación. En este capítulo pondremos el foco, entonces, en el objeto como lugar privilegiado para trabajar específicamente las memorias del exilio político en México a partir de algunas propuestas artísticas de la segunda generación: Árbol del desexilio (2006-2010) y 7Historias (2008) de Mercedes Fidanza, Un niño de 30 años (2006) y El niño que odia (2007-2011) de Tomás Alzogaray, y El Objeto del Exilio (2013) de Liza Casullo y Federico Joselevich Puiggrós. Reflexionaremos en torno a las múltiples memorias del exilio que condensan las propuestas artísticas a partir de presentar los objetos que han estado en tránsito: desde las que "añoran” al país refugio como aquellas que plantean los conflictos que tuvo la segunda generación en particular o las que mantienen una memoria cambiante e integrada por distintas voces $-\mathrm{y}$ objetos.

\section{Objetos colectivos en Mercedes Fidanza}

Mercedes Fidanza es una artista visual nacida en Buenos Aires en 1974. Durante un período de su infancia, desde 1976 hasta 1983, vive en el Distrito Federal en México junto con sus padres Amilcar Fidanza y Adriana Martínez, exiliados de la última dictadura cívico-militar argentina. Luego regresa a la Argentina y, una vez instalada, estudia cerámica en el IUNA y escultura en la Escuela Nacional de Bellas Artes Prilidiano Pueyrredón. Realiza talleres con Leo Vinci, Enio Iommi y Ricardo Oliva. Gran parte de sus producciones interdisciplinares trabajan el tema de las migraciones, algunas de ellas son Retorno (2008), Migración Forzada (2009), Proyecto Cactus Migrantes (2010). En este capítulo nos referiremos a dos proyectos que abordan el exilio político argentino en México y en los cuales los objetos son protagónicos: Árbol del desexilio (2006) y 7 Historias $(2008)^{120}$.

\footnotetext{
${ }^{120}$ A su vez, Mercedes Fidanza junto con Paula Arellano -también hija de exiliados políticos- coordinan el taller artístico-social "Fronteras Migrantes", un proyecto que "nació de la preocupación por la situación que atraviesan los jóvenes que deben migrar por diversos motivos, laborales o por estudio o por temas familiares, entre otros." (Arellano y Fidanza, 2012, p. 1).
} 
Árbol del desexilio es una serie de intervenciones urbanas realizadas en Argentina y en México ${ }^{121}$. A rasgos generales, estas acciones consistieron en un encuentro entre exiliados en un espacio público como una plaza o un parque -en Argentina se llevó a cabo en la Plaza de los dos Congresos (CABA, 2006); en la Plaza San Martin de Tours (CABA, 2007); en la Universidad de Córdoba (Ciudad de Córdoba, 2009); en una acción urbana en el Centro Cultural de la Cooperación (CABA, 2010), y en México se realizó en el Bosque Cuauhtémoc Medina (Morelia, 2008)- en donde cada participante entrelaza en un árbol vestimentas u objetos del exilio (imágenes 1-5). Las vestimentas, en su mayoría vestidos bordados mexicanos, se presentan colgando de perchas en la copa del árbol y los objetos más pequeños se encuentran sobre el tronco como una suerte de ritual de ofrenda. Asimismo, en las intervenciones urbanas están presentes las valijas de viaje en las que trasportaban los vestidos y objetos. Cada ocasión tuvo sus particularidades debido al árbol elegido, a la gente que participó -distintos exiliados en México, Nicaragua, Ecuador, Venezuela, entre otros- y al desarrollo propio que Mercedes le fue dando a la serie de intervenciones. En el caso del encuentro realizado en la Plaza de los Dos Congresos la artista eligió dos árboles que estaban unidos por sus ramas y los señalizó en el suelo con dos círculos blancos concéntricos superpuestos, generando un espacio intermedio en donde "se dirimía sobre la tierra el conflicto de la doble identidad: la pertenencia a dos lugares, a dos nacionalidades -como argenmex-, simbolizada por dos árboles que hunden sus raíces en la tierra y cuyas ramas abrazan en la copa, como refugios que gestan un nuevo ámbito de protección." (Pérez Rocca, 2008, p. 29).

7Historias (2008) es una instalación realizada en un espacio cerrado, una sala de exposición (imágenes 6-13). En ella se presenta como objeto protagonista un camisón de 1981 que fue confeccionado en México y utilizado por la madre de un hijo nacido en el exilio. Este objeto se encuentra intervenido por Mercedes con pequeñas piezas cerámicas que remiten a cactus, y aparece presentado en dos formatos distintos: por un lado se exponen fotografías de siete mujeres exiliadas vistiendo dicho camisón, y por otro lado se presenta el objeto en cuestión colgado de una percha en el centro de la sala.

En un primer acercamiento a los dos proyectos artísticos se puede ver la insistencia en presentar (no re-presentar) uno o varios objetos de las personas que se exiliaron. En Árbol del desexilio, los objetos aparecen acompañados de las valijas y

${ }^{121}$ Árbol del desexilio surge a partir de una serie de performances que Mercedes realizó de manera individual en la vía pública, llamada "Reparación del exilio" (2002). 
ligados, entonces, a su capacidad de ser portátiles, transportables y de haber estado en tránsito, formando parte de las historias de vida de los exiliados (imagen 3).

Con respecto a las particularidades de los objetos expuestos y el tipo de ritual que se genera alrededor en Árbol del desexilio, llama la atención la fuerte presencia -del estereotipo- de la cultura mexicana. Ya sea por el tipo de bordado de los vestidos, el color de los objetos -muñecos, sombreros, pañuelos, adornos, alebrijes, tejidos- o la forma de estar expuestos sobre el tronco como un ritual de ofrendas, es inmediata la evocación a las tierras mexicanas a través de su cultura popular (imagen 4). En este sentido aparece la fuerte impronta de la historia de Mercedes, su exilio político en México y su construcción identitaria argenmex - a pesar de la presencia de participantes que se exiliaron en otros lugares. Se elige representar el exilio en tanto experiencia productiva y transformadora, especialmente en el intercambio cultural argentino y mexicano que se dio en ambas generaciones de exiliados.

Otra característica de ambos proyectos es la dimensión colectiva y de experiencia compartida que contienen los objetos. En Árbol del desexilio fueron convocadas distintas personas que han transitado el destierro para prestar los objetos personales del exilio, de modo que la intervención en el árbol estaba conformada de todas estas memorias. En 7Historias se visibilizan múltiples historias de exiliadas que visten el camisón y, de esta manera, se superponen las memorias ligadas al destierro: el camisón condensa la memoria de la mujer que vistió ese camisón en el exilio durante su embarazo y, cada fotografía nos muestra una nueva historia de una exiliada teniendo puesto dicho camisón. Asimismo es interesante mencionar que esta instalación genera una invitación a reflexionar sobre el rol de la mujer en el exilio, evocado por las figuras femeninas vistiendo el camisón en las fotografías, por la historia de dicha prenda y por las pequeñas piezas cerámicas sobre el camisón y el suelo. En una entrevista, Mercedes plantea que la imagen del cactus le interesó mucho ya que tiene que ver con la idea del sobreviviente al ser una planta que "guarda el agua en su interior y puede sobrevivir en el clima más adverso" 122 (Mercedes Fidanza, s/p.) (imágenes 10 y 13).

En Árbol del desexilio resulta fundamental reflexionar sobre el lugar en donde se ubican los objetos que han viajado, que se han trasportado de territorio: un árbol -el gomero de 230 años en la ciudad de Buenos Aires en la plazoleta San Martin de Tours, entre otros- que se destaca por el grosor de su tronco y la extensión de sus raíces. Este

\footnotetext{
${ }^{122}$ Varios proyectos de Mercedes se basan y reflexionan sobre esta idea de cactus: Proyectos cactus migrantes, Mapas migratorios, entre otros.
} 
emplazamiento genera un lazo muy fuerte entre los objetos que han viajado con los exiliados y el anclaje a una tierra en particular, a una pertenencia identitaria, una nacionalidad específica. La figura del árbol condensa múltiples significados de acuerdo a cada cultura -son conocidos, entre nosotros el Árbol de la vida asociado a la cultura mexicana ${ }^{123}$, el Árbol del Conocimiento del Bien y del Mal, el árbol como axis mundi en las cosmovisiones indígenas, etc.-, ${ }^{124}$ uno de ellos es el árbol genealógico que, según Mircea Eliade, es una de las "relaciones místicas entre los árboles y los hombres":

La más categórica de estas relaciones místicas parece ser el que las razas desciendan de una especie vegetal. El árbol o el arbusto es considerado como el antepasado mítico de la tribu. Generalmente, este árbol genealógico está en estrecha relación con el culto lunar; el antepasado mítico, asimilado a la luna, está representado bajo la forma de una especie vegetal (...) Pero lo que ante todo nos interesa en este capítulo es el circuito de vida entre los dos niveles: el nivel vegetal y el nivel humano. El hecho de que una raza descienda de una especie vegetal presupone que la fuente de la vida está concentrada en ese vegetal, y, por tanto, que la modalidad humana está en él, en estado virtual, bajo forma de gérmenes y de semillas. (1974, pp. 75-78).

\footnotetext{
${ }^{123}$ Originalmente, el árbol de la vida era utilizado en el período colonial para la evangelización de los nativos por medio de la representación de la historia de la creación según la Biblia. Asimismo esta representación, con sus variantes, se ha convertido en una artesanía muy popular en México, fabricada principalmente en el municipio de Metepec.

${ }^{124}$ Cfr.: "En los mitos y en las leyendas relativas al árbol de la vida nos ha aparecido muchas veces implícita la idea de que está en el centro del universo y de que enlaza el cielo, la tierra y el infierno. Este detalle de topografía mítica tiene especial valor en las creencias de los pueblos nórdicos y centroasiático, aunque probablemente es de origen oriental (mesopotámico). (...) Con frecuencia, el árbol se encuentra en la cima de una montaña, en el centro de la tierra. Los tártaros Abakan hablan de una montaña de hierro sobre la que crece un abedul de siete ramas, símbolo probablemente de los siete pisos del cielo (ideograma de origen babilónico, según parece). En los cantos de los chamanes ostiaks Vasjugan, el árbol cósmico tiene, como el cielo, siete peldaños; atraviesa todas las regiones celestes y hunde sus raíces en las profundidades subterráneas. (Eliade, Le chamanisme, 245s) (...) La estela sagrada y el árbol son símbolos que equivalen al poste cósmico que sostiene al mundo y que está en el centro del universo. Los dioses de los altaicos atan los caballos a ese poste cósmico, alrededor del cual giran las constelaciones. (...) También los indios tienen la idea de un eje cósmico, representado por un árbol de la vida o un pilar, situado en el centro del universo (A. Coomaraswamy, Elements of Buddhist Iconography, 82; P. Mus, Barabudur, I, 117s). En la mitología china, el árbol milagroso crece en el centro del universo, allí donde debería estar la capital perfecta, Une las novenas fuentes a los novenos cielos. Se le llama $<$ madero erguido $>$ (Kieou-Mou), y se dice que nada de lo que está próximo a él y vertical puede dar la sombra al mediodía (Granet, La pensé chinoise, 324). Este árbol cósmico recuerda a la estela, soporte del mundo, <eje del universo> (axis mundi) de las cosmologías altaicas y norte-europeas. El árbol, en estos mitos, expresa la realidad absoluta en su aspecto de norma, de punto fijo, soporte del cosmos. Es el punto de apoyo por excelencia. Por consiguiente, la comunicación con el cielo sólo puede efectuarse en torno a él o por intermedio suyo." (Eliade, 1974, pp. 74, 75).
} 
Cuando pensamos en los objetos colgando de las ramas de la copa de un gran árbol en la acción de Mercedes, se nos impone la imagen del árbol genealógico, en el cual figura la familia extendida. A partir de esta metáfora, se torna, entonces, importante el lugar que ocupan los objetos en Árbol del desexilio. En este caso no se hace referencia a los antepasados, sino, más bien, al territorio simbolizado tanto en el árbol como en los objetos: las raíces anclan el sentido identitario en el nicho de nacimiento, generando un ritual de re-definición a partir de una vuelta hacia el origen, en un ejercicio de "desexilio". A su vez, las raíces del árbol contienen objetos transportables, en movimiento y desterritorializados que han acompañado la vida de los exiliados. De esta manera se vuelve paradojal este doble juego de querer echar raíces en una tierra a partir de objetos del exilio, objetos en tránsito, des-terrados. Como analizamos en el primer capítulo, esta reflexión aparece manifiesta en la carta de las Hijas e Hijos del Exilio: "El exilio partió en dos nuestras vidas: somos argentinos, pero también de México, España, Venezuela, Italia, Brasil, Holanda, Suecia, Francia, Nicaragua (...) Y esto nos dificulta echar raíces", "Todos transitamos en mayor o en menor medida la condición de ser "el otro", el "bicho raro", "Nuestras vidas han estado signadas por ello: siempre fuimos la persona extraña, la que no encaja." (Hijos e Hijas de exiliados, 2006, s/p.). Mercedes también lo manifiesta en un texto leído en una de las acciones de Árbol de desexilio:

Una vez me transformé en cactus para sobrevivir en el desierto árido y frio de la gran ciudad porteña.

En el centro de esa planta escuché el sonido de un tambor, un pulso que al correr por mi sangre cicatrizó algunas heridas y expulso las espinas de mis pies.

Así volví a caminar y a buscar a mis pares, a mis hermanos, a mis amigos, hombres, mujeres y niños.

A veces los pincho sin querer con esa parte de mi ausencia que para ellos es extraña, con esa pregunta sobre la identidad que me obliga a quitar cada espina para limar la ignorancia.

Quedé escamondeada, agujereada, por allí ahora soplan los vientos, las canciones de mis ancestros que me guían para volver a pisar esta tierra descalza, sin miedo, desespinada, transitando el desexilio, que es construcción de lazos sociales, de memoria cultural en tanto transmito esta experiencia, este proceso.

No me desexilio para olvidar sino para recordar y sumar mi propia historia al cuerpo social.

Desexiliandome, pisando el suelo, besando la raíz en su 
latido. (página web, s/p.). ${ }^{125}$

En ambos proyectos de Mercedes se muestra una pulsión por querer fijar un relato, por querer narrarse con parámetros estables y duraderos. Sin embargo, el relato dominante que aparece en su reconstrucción identitaria es el de la travesía, el de una identidad que está en tránsito; de esta manera no se logra del todo anclar a una tierra determinada y se hace evidente la puja continua para lograr construir una identidad actual, una identidad activa/presente, como afirma la artista: "Intento una reparación del exilio, volver a la tierra de uno no es salir del exilio. Éste continúa adentro hasta que se lo enfrenta diciéndole: No corras, no te persigas, ésta es tu casa.” (2011). El concepto de “desexilio" lo retoma Mercedes Fidanza a partir de un artículo de Mario Benedetti "El 'desexilio"” en donde afirma que "el desexilio será un problema casi tan arduo como en su momento lo fue el exilio, y hasta puede que más complejo" (1983, s/p.). Consideramos problemático el uso de este término dado que no creemos que se pueda lograr, especialmente para la segunda generación, un “desexilio" como tal -recordemos, además, que la vuelta al país de origen de los padres muchas veces representó el "exilio" de los niños. En cambio sí lo creemos posible utilizar en relación al duelo que implica asumir una identidad dual. En estos proyectos artísticos aparece, entonces, la memoria del exilio en una suerte de "ritual" para realizar un duelo tanto en la dimensión íntima -de Mercedes- como en la colectiva, integrada por distintas voces y objetos de exiliados. Es, entonces, una memoria en constante transformación y actualización.

\section{Los niños-adultos de Tomás Alzogaray Vanella}

Tomás Alzogaray Vanella es un artista visual nacido en Argentina en 1976 que reside actualmente en Córdoba. Sus padres eran militantes universitarios y, tras dos allanamientos en su casa y luego de saber que figuraban en las "listas negras" de las Fuerzas Armadas, se exilian en México. Primero se traslada su papá y después su mamá junto con él al poco tiempo de su nacimiento, en 1976. En un primer momento se exilian en Torreón, en el norte de México, donde nace su hermana y luego se instalan en el Distrito Federal. Tomás asiste al jardín de infantes y cursa dos años de la primaria en el DF y más tarde, a sus ocho años, en diciembre de 1983, regresa a la Argentina junto con su familia. Se recibe de Licenciado en Artes Plásticas en la UNC, más

\footnotetext{
125 "Cactasea desespinada" es un texto introductorio leído en el encuentro de Árbol del desexilio de
} Mercedes Fidanza realizado en junio de 2007. 
específicamente en pintura, y trabaja en torno a las artes visuales, la escenografía y la performance, entre otras disciplinas. Desde de 1998 es profesor y capacitador en arte de personas con y sin discapacidad y en situación de vulnerabilidad. A sus 30 años, en el año 2006, viaja a México -por decisión propia- y se queda hasta el 2013. Además de su tesis de licenciatura que aborda el exilio político, realiza cinco cuadernos que reflexionan explícitamente sobre este tema: Un niño de 30 años (2006), Circo de los payasos bigotones (2007), Manuelita ¿a dónde vas?, Los aviones son de papel y El niño que Odia (2007-2011).

En primer lugar reflexionaremos sobre el "cuaderno madre" que inició la serie: Un niño de 30 años. Este cuaderno fue realizado en el viaje que Tomás hizo el año 2006 a México, al encontrarse con dos objetos que usaba en la escuela: un cuaderno de marca Scribe -de fabricación mexicana- ${ }^{126}$ (imagen 14) y un lápiz bicolor azul y rojo. El cuaderno consiste en una serie de 95 dibujos con frases escritas en algunos de ellos (imágenes 15-109). En un primer acercamiento a los dibujos vemos el carácter enérgico, perturbador, descarnado, sin paliativos de la propuesta: se representan temas y elementos violentos (cuchillos, pistolas, genitales sangrando, cabezas decapitadas, heridas, cicatrices) con trazos fuertes -como apretando el lápiz-, con el color rojo la mayoría de las veces representando la sangre, en palabras de él: "fue un poco vomitivo (...) donde todos los días estuve dibujando así como un vómito, entre 10 y 20 dibujos diarios durante uno o dos meses. (...) yo lo llamo el cuaderno madre y donde hablo de esta relación directa de mi exilio." (2015, s/p.).

El cuaderno es explícitamente autobiográfico: un niño, representado como un adulto de 30 años pero en una escala correspondiente a un niño, algo así como un "adulto pequeño", atraviesa situaciones o acciones con fuertes reflexiones/definiciones identitarias, algunas de ellas son: la relación entre padre e hijo y madre e hijo -la representación simbólica de "matar a los padres"127-, la toma de conciencia de haber nacido en plena dictadura cívico-militar, el exilio político y la doble identidad argentina y mexicana. Asimismo hay elementos que se mantienen a lo largo de toda la serie de dibujos y que van conformando una cierta narración, que nos contextualizan en tres

\footnotetext{
${ }^{126}$ La marca Scribe nació en 1962 y se convirtió en México en un referente para cuatro generaciones de consumidores que crecieron con los cuadernos (abarcaban desde el nivel preescolar hasta el universitario).

${ }^{127}$ A diferencia de muchos hijos de exiliados, la imposibilidad del parricidio simbólico es un tema que plantean los hijos de desaparecidos: "Dicen que hay que matar a los padres, pero si otros lo hacen por nosotros (aboliendo la metáfora, dejándonos desnudos y literales) ya sólo nos queda la eterna errancia." (Nicolás Prividera, "Bufido". Recuperado de: www.revistaenie.clarin.com/escenarios/teatro/bufido-nicolas-prividera_0_572342999.html.
} 
sentidos: en el mundo de la infancia por el tipo de dibujo naif y la presencia recurrente de un oso de peluche, una sillita para niños de madera (típica de los jardines de infantes), el disfraz de Spiderman, la representación del cuento de Caperucita Roja, las frases como "veo veo...”, “¿de qué color?”-en referencia al juego de niños-, “volver al nido", y, como mencionamos anteriormente, el propio soporte que recuerda Tomás que usaba en el jardín o la primaria: el cuaderno Scribe y el lápiz bicolor. También podríamos decir que varias situaciones remiten a un contexto onírico por la presencia de camas, una almohada y de ciertas frases como "y el que nunca había tenido sueños salvajes", "soñó al fin" y "sueño con serpientes"128. El otro tema que aparece continuamente representado es su exilio e identidad dual, su construcción argenmex como algo perturbador. El color rojo y el color azul -condensados en las dos caras del mismo lápiz- aparecen bien diferenciados, casi como "enemistados", marcando continuamente una dualidad, separando dos mundos, tanto en su representación corporal, como en las palabras y frases. Esto se puede ver, por ejemplo, en un dibujo con la bandera argentina y la mexicana clavada a cada lado de su cabeza y con la pregunta “Qué país te gusta más?", en otros dibujos del mismo adulto-niño representado de forma dual, espejado (imágenes 21, 32, 34, 67, 68, 69, 70), en las frases "por qué no tomás mate? nene...", “de dónde soy", "nací en el 76”, o en las referencias a ambas culturas tanto en imagen como en palabras: la "alberca" olímpica y la "pelopincho", partes del himno argentino, el mate, la "casita de Tepoz" "29 , la expresión mexicana "no quepo" o "güerita". A su vez, en todo el cuaderno se hace presente la violencia y el dolor por medio del color rojo aludiendo a la sangre, una cicatriz de una operación del apéndice, la representación de armas -pistolas y cuchillos ensangrentados- y el parto de su madre ${ }^{130}$.

Un niño de 30 años inicia una serie de cuadernos en la cual hay otros cuatro que abordan o se relacionan con el tema del exilio de Tomás, también en una clave autobiográfica. Si bien no reflexionaremos en profundidad sobre todos estos cuadernos, presentaremos brevemente los temas abordados: El circo de los payasos bigotones (2007) realizado en un cuaderno Gloria -de fabricación argentina- es el relato de lo que pasaba en el país en plena dictadura cívico-militar, narrado por un niño, hijo de

\footnotetext{
${ }^{128}$ Esta frase alude también a la canción popular de Mercedes Sosa "Sueño con serpientes"

129 Tepoz en referencia a Tepoztlán, una localidad del norte del estado de Morelos, en el centro-sur de México.

${ }^{130}$ En este capítulo intentamos hacer sólo una introducción en el abordaje de los cuadernos artísticos de Tomás Alzogaray por cuestiones de espacio y tiempo. Son muchos los temas que se podrían profundizar a partir de sus dibujos: el tema de la sangre, la castración, la relación con las obras de Frida Kalho, etc.
} 
militantes. Manuelita ¿a dónde vas? (2007-2011) elabora más explícitamente el exilio desde la canción infantil argentina $\mathrm{y}$, asimismo, está relacionado con su tesis de licenciatura en la cual trabajó plásticamente con unos caparazones de tortugas ${ }^{131}$, y Los aviones son de papel (2007-2011) aborda tanto los vuelos de la muerte como los viajes del exilio político.

Por último, presentaremos brevemente el cuaderno El niño que odia (2007-2011) que es muy interesante porque aborda las dificultades que presenta un niño -Tomás- en el retorno al país de origen de sus padres, para reinsertarse en la escuela. Aparece, entonces, la representación del odio en un niño:

(...) es el niño que odia, es el odio que tiene en la escuela. Recuerdo que cuando llegue acá tuve realmente muchos desajustes o problemas a la hora de adaptarme...creo que tuve la suerte de venir a los 8 años donde todavía estaba más flexible, las personas que vinieron después o de edad más grandes tuvieron más dificultades (...) yo tenía más problemas con la maestra que con los compañeros, recuerdo más odio con la maestra que los compañeros, porque decía que no sabía escribir. (Tomás, 2015, s/p.).

Esta serie de 21 dibujos representa las dificultades que tiene el niño con la maestra por supuestos "problemas de escritura" (imágenes 110-132) a partir de la representación de una pluma/marcador que por momentos se torna en un arma que dispara. Es, al igual que Un niño de 30 años, una autobiografía de los problemas y conflictos que plantea un universo infantil atravesado por la violencia. Representaría el caso contrario si lo comparamos con las llamadas "novelas de aprendizaje" dibujar el crecimiento y progreso de un niño en la escuela y su cotidianeidad, aparecen

\footnotetext{
${ }^{131}$ Esta propuesta artística también aborda el tema del exilio, en palabras de Tomás: "Entonces yo estaba haciendo la tesis y había hecho una parte de duelo ya con el tema México y ya había decidido que era de aquí, Argentina. Llego a Ecuador y se me despiertan saberes ancestrales de los sabores, de los sensorial, algo totalmente físico. Olor, color, sabores de una cultura que no niega su parte latinoamericana, somos mañosos con reconocernos como parte de América Latina. Cuando me encuentro en Ecuador siento mi naturaleza. Reconocerme en "ser" argentino no me convencía, no me satisfacía. Lo sensorial, los olores y sabores que más te ligan con la infancia, el olor a achiote, papaya, guayaba etc., estaban instalados en otro lugar, es algo que trasciende, que está incorporado a tu ADN. Expuso algo que yo había encapsulado. Me encuentro con unos caparazones en la playa, porque los pescadores mataban a las tortugas, entonces me traigo dos caparazones de tortugas de mar y hago unas copias en resina y empiezo a trabajar. (...) Entonces lo que hice fue hacer 5 caparazones en donde trabajaba los órganos de mi cuerpo del lado externo de los caparazones pintados a la manera de los alebrijes". (2015, s/p.).

${ }^{132}$ Es un género literario que relata la transición de la niñez a la vida adulta. El término alemán original, Bildungsroman significa literalmente novela de formación o novela de educación.
} 
las trabas y dificultades estancadas, el odio no resuelto y la violencia simbólica como respuesta frente a los padecimientos. No hay, en este caso, un "final feliz".

Todos los cuadernos tienen la capacidad de ser objetos transportables sin dejar de estar anclados simbólicamente a una determinada cultura infantil y nacional -el Scribe de México y el Gloria de Argentina. Estos cuadernos escolares fueron elegidos específicamente por lo que condensaban de forma simbólica: fueron parte de la construcción de la identidad ligado a lo nacional en el período de la infancia, en cierto sentido son parte del rol del estado en la construcción del "ciudadano". Es el cuaderno que evoca el imaginario sobre la escuela como lugar privilegiado de la formación del ser nacional. Entonces, dada esta fuerte carga simbólica, son objetos que han sido trasportados de un país a otro sin perder su anclaje en la cultura de origen. Resulta, por ende, más fuerte aún el contraste entre el cuaderno de marca Scribe o Gloria y su interior con dibujos a contrapelo de lo que debería ser una "conformación del ciudadano" o del relato de aprendizaje "feliz". De esta manera hay un señalamiento al estado argentino por esta expulsión del niño del país y, lógicamente, del derecho a la educación del mismo.

Cada uno de estos cuadernos escolares los podríamos llamar, también, "cuaderno de viaje/bitácora". El cuaderno central que inauguró la serie fue realizado efectivamente en un viaje que realizó Tomás a México en el 2006. A su vez, en Un niño de 30 años los temas abordados en su interior no nos hablan de cualquier viaje, sino del viaje forzado y doloroso, del exilio político. En todos los cuadernos se hace referencia a situaciones muy perturbadoras de la construcción identitaria de este "adulto-niño", en donde el exilio es un tema central. A diferencia de muchas de las producciones analizadas en los capítulos anteriores, estos cuadernos no representan los recuerdos nostálgicos o las vivencias más añoradas del exilio, sino que rememoran a aquel niño que sufrió y padeció su exilio y, a su vez, plantea los problemas que persisten en un joven de 30 años en relación a su construcción identitaria. Es importante destacar que, en el caso de Un niño de 30 años el cuaderno es realizado en un viaje que Tomás hace "por decisión personal” a México a sus 30 años porque, según sus palabras: "había cosas que me parece que no había terminado de decidir. Yo no decidí irme a México y yo no decidí volverme de México tampoco.” (2015, s/p.). En este sentido el cuaderno 
pone en evidencia las tensiones y conflictos del exilio experimentadas en la infancia pero que continúan en la vida adulta. ${ }^{133}$

Estos múltiples sentidos condensados, cuaderno escolar/cuaderno de viajebitácora, están, entonces, atravesados por el exilio en todo el dispositivo artístico. Lejos del relato nostálgico del exilio, del intercambio "feliz" entre ambas culturas, del aprendizaje escolar, Tomás presenta una memoria catártica, que expone en primer lugar las heridas abiertas, contradicciones, perturbaciones identitarias de este niño-adulto exiliado.

\section{Los objetos del agradecimiento}

El Objeto del Exilio (2013) fue una instalación realizada por Liza Casullo y Federico Joselevich Puiggrós ${ }^{134}$ en un homenaje a "México por su amistad y solidaridad con los académicos e intelectuales exiliados" del Instituto Gino Germani de la Facultad de Ciencias Sociales (UBA), llamado "Paisaje del amparo y el arraigo", que tuvo lugar en la Biblioteca Nacional ${ }^{135}$. La instalación se armó a partir de los objetos que eligieron y prestaron distintos exiliados - de las dos generaciones- bajo la pregunta “¿Hay algún objeto que represente algo del exilio mexicano para vos?” (imagen 133).

Es interesante notar que la mayoría de los objetos que aparecen en la instalación son aquellos que condensan aspectos de la cultura mexicana (imágenes 134-145): arte cerámico mexicano, una máquina para hacer tortillas, un disco de Odisea burbujas ${ }^{136}$, un chile, una muñeca de trapo conocida como "Marías", dulce de tamarindo "pulparindo", la expresión escrita en un papel "ni modo". También aparecen, en menor cantidad, los objetos que representan el contacto con los familiares argentinos que estaban lejos, como por ejemplo, unas cartas en papel y un cassette con cartas grabadas. Liza y Federico sostienen que fue un "ejercicio que nos hizo distinguir entre 'objetosrecuerdo' que rememoran cosas del exilio como pasado y 'objetos-presente' que hablan

\footnotetext{
${ }^{133}$ Alejandrina Falcón analiza las figuraciones del "niño-adulto" en "El lugar de la "segunda generación" en la investigación sobre el exilio político. Notas en torno al documental Argenmex, exiliados hijos" publicado en la revista Aletheia, volumen 5, número 9, octubre 2014. En este capítulo, vemos cómo esa figura se invierte en un "adulto-niño", es decir, un adulto de 30 años que necesita volver a su infancia para exponer sus memorias traumáticas.

${ }^{134}$ Tanto Liza Casullo - hija del intelectual Nicolás Casullo- como Federico Joselevich Puiggrós - de la familia de Osvaldo Puiggrós- son hijos de exiliados en México y trabajan en profundidad sobre sus memorias del exilio en otras propuestas artísticas, como por ejemplo la instalación Passus exilii (2011) de Federico o la conferencia performática Capitulo 32 (2014) de Liza.

${ }^{135}$ Para ampliar la información sobre el evento, véase "Reseña de la actividad: Homenaje a México por su amistad y solidaridad con los académicos e intelectuales exiliados" de Soledad Lastra publicada en Aletehia, volumen 4, número 8, abril 2014.

${ }^{136}$ Odisea Burbujas es una serie de televisión mexicana dirigida al público infantil.
} 
de marcas culturales que llegan hasta hoy". Como se puede ver en las imágenes, hay, sin embargo, una predominancia de estos "objetos-presente" en tanto son objetos que hacen añorar la cultura mexicana, más que recordar el exilio en sus diversos aspectos. Hay una suerte de "agradecimiento" a México, de recuerdo "feliz" que representa la cultura mexicana en los exiliados. En este sentido en el mismo homenaje habló Héctor Schmucler sobre algunos ejes centrales que considera en la experiencia del exilio, entre ellos

(...) mencionó la importancia de reconocerse como "nostálgicos" ante México, como "tierra perdida", sentimiento que alberga no sólo los hondos lazos de amistad construidos en distintos espacios mexicanos durante su exilio, sino en saberse que habían estado acompañados y contenidos: "México nos marcó que éramos exiliados y a su vez hizo que el padecimiento del exilio se diluyera en parte, es decir, nos desexilió. (Lastra, 2014, p. 3).

En esta instalación aparece, entonces, el exilio en clave nostálgica y de agradecimiento. Se puede notar que, si bien la instalación la llevaron a cabo hijos de exiliados, sin embargo muchos de los objetos pertenecen a la primera generación y el evento se enmarca en el "homenaje a México". Es decir, no se propone indagar en los conflictos más íntimos de los exiliados sino en el agradecimiento a México como país del "amparo y del arraigo".

\section{Las múltiples memorias de lo objetual artístico en los hijos exiliados}

Los objetos vehiculizan recuerdos individuales del pasado, que se definen en el presente, con un "horizonte de expectativas" sobre el futuro (Jelin, 2002), y que, además, se enmarcan socialmente. Halbwachs plantea que los objetos "son como una sociedad muda e inmóvil" (2011, p. 188) ya que perduran físicamente estables a través del tiempo y, a su vez, contienen los lazos sociales de nuestra cultura y de nuestras elecciones -estéticas, funcionales, emocionales, etc.- en un en-grupo, con marcos estables definidos socialmente y con una determinada memoria colectiva (habiendo tantas memorias como grupos sociales existen). Los objetos presentados en estos proyectos artísticos, se apartan, claramente, de su uso funcional y se los convierten en objetos de memorias, en testimonios históricos ligados a una acción ritual, con una 
mirada puesta explícitamente en lo simbólico. Algunas de las preguntas que se hace Jean Baudrillard en su libro apuntan en este mismo sentido: "cómo son vividos los objetos, a qué otras necesidades, aparte de las funcionales, dan satisfacción, cuáles son las estructuras mentales que se traslapan con las estructuras funcionales y las contradicen, en qué sistema cultural, infra o transcultural, se funda su cotidianidad vivida" (2010, p. 2).

Como vimos, el objeto ocupa un lugar importante entre los exiliados políticos. Son protagónicos tanto en las obras artísticas como en las voces de exiliados, debido a que el "irse con lo puesto" - postales, fotos, casettes, cartas, sabores, etc.- significó para muchos un vínculo al país de origen -o de los padres- a través de uno o varios objetos, un lugar de memoria radicado en una materialidad, una representación y contacto con los familiares y el imaginario nacional. En este sentido son objetos de memoria -en referencia a los lugares de memoria ${ }^{137}$ - dado que representan tanto parte de una historia íntima y familiar como parte de una identidad ligada a lo nacional (dependiendo del objeto puede representar ciertas características estereotipadas de la cultura argentina o mexicana).

Nos surgen, entonces, distintas preguntas: ¿qué tipo de objeto aparece?, ¿qué memorias se representan?, ¿qué memorias del exilio construyen los objetos de las producciones artísticas?, ¿qué representa para la segunda generación de exiliados el "irse con lo puesto" de los padres?, ¿son los mismos objetos aquellos del "irse con lo puesto" a los "objetos del regreso/presente”?, ¿son objetos que estereotipan lo nacional o la cultura popular?

Si ampliamos la mirada sobre los objetos que fueron importantes para los exiliados -más allá de los que recuperan las producciones artísticas analizadas acáaparecen otros: "Crecimos añorando una tierra que apenas habíamos conocido. La Argentina en muchos casos se reducía a un par de postales, anécdotas, olores y sabores." (Hijas e Hijos del Exilio, 2006, s/p.). Aparecen entonces los objetos de la ida o del durante, aquellos que reponen "lo que está lejos" en un país extranjero, ya sea la

\footnotetext{
${ }^{137}$ Hay extensos estudios en torno a los lugares de memoria, concepto desarrollado por Pierre Nora (2008) que, a niveles generales, caracteriza a estos lugares como espacios materiales -ya sean portátiles, topográficos, monumentales y arquitectónicos-; funcionales, ya que aseguran la cristalización del recuerdo y su transmisión; y simbólicos, en tanto se los relaciona con acontecimientos o experiencias construidas por personas. De acuerdo al autor, estos lugares tienen una doble pertenencia por ser objetos que imbrican una narración dentro de otra ("puesta en abismo"), es decir que, a modo de matrioskas, comienzan con una intención inicial para luego ser reconstruidos infinitamente por distintos sentidos otorgados.
} 
familia, el hogar, o "la Argentina". Los niños exiliados muchas veces construyeron con los recuerdos de sus padres -algunos condensados en objetos- la familia, la cultura popular y lo nacional, es decir todo aquello que estaba lejos y que era, para muchos, desconocido: "Quienes nacimos afuera o nos fuimos de muy pequeños, conocimos al resto de la familia sólo por fotos, casettes, cartas o visitas ocasionales. Quienes nos fuimos más grandes vivimos junto a nuestros padres el duelo de extrañar a todos los seres queridos y la propia cultura" (Hijas e Hijos del Exilio, 2006, s/p.). En este sentido se destacan, como analizamos en el capítulo 3, las fotografías/objeto que, por ser pequeñas, se las podía transportar en la valija y conservar en el país refugio, habilitando la función de reponer y "conocer", en cierta medida, a los familiares argentinos que estaban lejos. Entonces, si para los padres algunos de los objetos del "irse con lo puesto" podía representar en el exilio aquello con lo que rememorar y añorar el país de origen, para muchos niños podían cumplir una función hasta didáctica.

Ahora bien, ¿qué tipo de objetos se destacan en las producciones artísticas analizadas en este capítulo? Tanto en Árbol del desexilio, 7Historias, Un niño de 30 años y El Objeto del Exilio aparecen, en primer lugar, objetos que condensan la cultura mexicana -muchas veces estereotipada-: los vestidos y tejidos típicos mexicanos, la bandera, muñecos tradicionales, el cuaderno escolar Scribe, y objetos ligados a los sabores como la máquina para hacer tortillas, el "pulparindo", el chile, etc. Estos objetos entonces, representan el exilio en relación al intercambio cultural, a la marca que dejó México a los que volvieron y viven actualmente en Argentina (distintos serían los objetos del exilio que elegirían los argentinos que se quedaron a vivir en México ${ }^{138}$ ). Como vimos en el primer capítulo, esta marca cultural, este ser argenmex se representó de distinta manera en una y otra generación: por un lado la generación adulta se autoidentifica como argenmex desde un lugar de empatía afectiva hacia lo mexicano, con un tono melancólico o nostálgico y de agradecimiento al país refugio; por otro lado la generación de hijos absorbió de manera profunda la cultura mexicana -en el jardín de infantes, la escuela y espacios de sociabilización por fuera del seno familiar- por lo cual se conformaron en una identidad dual, propiamente argenmex.

En este sentido Un niño de 30 años problematiza esta añoranza que puede generar un cuaderno Scribe en un argenmex que se crió los primeros años en México y

\footnotetext{
${ }^{138}$ Sobre el no retorno de exiliados políticos argentinos en México, véase la tesis de Soledad Lastra titulada Del exilio al no retorno. Experiencia narrativa y temporal de los argentinos en México de la maestría en Ciencias Sociales, FLACSO, México, 2010.
} 
que luego volvió a la Argentina. Ni bien abrimos el cuaderno, los recuerdos "nostálgicos" se cambian por otros ligados a una vivencia perturbadora en un niño y un presente de un adulto con problemas identitarios en conflicto. El contraste que genera Tomás entre el exterior del objeto y su interior repone, en cierta manera, las otras memorias que están ausentes en muchos recuerdos y producciones sobre el exilio político. Algo similar sucede con 7Historias en el sentido en que se pone énfasis en un objeto que simboliza el conflicto de una madre embarazada en el exilio. En Árbol del desexilio aparece también la doble cara del exilio: si miramos de cerca, la mayoría de los vestidos y objetos añoran la cultura mexicana, pero si tomamos distancia, vemos expuesto el conflicto identitario representado por la puja constante entre los objetos que han estado en tránsito y las raíces del árbol que intentan anclarlos a una tierra determinada.

Resulta importante, entonces, destacar que estos objetos en tránsito, en travesía, que han "acompañado" a los exiliados en sus distintos momentos, tienen múltiples significados -debido a la complejidad misma del exilio, objeto poliédrico y móvil (Silvina Jensen, 2011). Estas múltiples identidades quebradas, duales, en pugna constante, tienen que ver con la elaboración dinámica de una identidad presente, como afirma Arfuch (2005):

Lejos de configuraciones estáticas o totalizadoras, lo que se pone de manifiesto es la dimensión conflictiva de toda identidad -conflictividad dialógica, podríamos decir, volviendo a Bajtín-, su carácter no dado ni gratuito en el sentido de una mera coexistencia con otras: una identidad que pretendiera continuar tal como es, mantenerse sin cambios, correría el riesgo de marginalización o de cristalización. (p. 34).

Las memorias representadas de estos artistas en sus producciones se las podría agrupar en tres propuestas estéticas, en donde se potencian los tipos de memorias y las formas de representarlas: mientras Mercedes trabaja y elabora el duelo con las memorias múltiples -integra objetos de distintos exiliados en un proyecto y usa un mismo camisón para retratar a varias mujeres en otro- de forma abierta y participativa convocando nuevas historias en las plazas- y en constante transformación -las memorias van cambiando según los objetos que se cuelguen y el árbol que se elija-; Tomás elabora una memoria privada, íntima, autobiográfica y catártica, que se centra en los conflictos y contradicciones de un niño en el exilio y que se materializa en el 
cuaderno escolar/de viaje intervenido con sus dibujos de trazo infantil. Por su parte, la instalación El objeto del exilio, en un contexto público de homenaje a México, expone la memoria del "agradecimiento" al país de asilo, en una suerte de acto de afecto nostálgico donde se disipan los conflictos y las memorias están "adoradas" en cajas. 


\section{PALABRAS FINALES}

El lugar que ocupa el arte en las múltiples memorias es una de las problemáticas centrales que atravesamos en esta tesis. A lo largo de su desarrollo mantuvimos ciertas preguntas presentes: ¿cuáles son los medios artísticos para elaborar y transmitir las memorias?, ¿cuál es la especificidad de lo artístico en este contexto?, ¿qué relación existe entre el ritual, el duelo y el arte?, ¿qué lugar ocupa el arte en el espacio público y en la conformación de la memoria colectiva? Hemos indagado puntualmente en las producciones artísticas de aquellos argentinos que nacieron y/o vivieron en una muy temprana edad en el exilio político en México junto a sus padres. Muchos de ellos tienen a algún tío desaparecido y se criaron con la familia extendida a través de fotos, cartas y llamadas telefónicas. Son mexicanos y argentinos o argenmex y actualmente viven en Argentina.

Los medios artísticos elegidos para llevar a cabo estas prácticas no fueron para nada azarosos. Lo fotográfico, lo corporal y lo objetual condensan, en diferentes niveles -desde lo más subyacente e invisible hasta lo más evidente y expuesto-, maneras de transformar y trasmitir esas memorias traumáticas y del exilio. Son medios característicos del trabajo con la memoria que el arte retoma y le coloca su propio sello, su particularidad. Repasando brevemente, vimos que la fotografía, en sus usos artísticos y no artísticos, ha sido un medio elegido por familiares y artistas para denunciar las desapariciones forzadas de personas; para recordar y/o adorar al ser querido a través de la foto talismán o reliquia; para transportar en el exilio y "acercar" a los parientes o amigos lejanos; para elaborar el trauma individual/familiar y socializarlo con la comunidad. Por su parte, el cuerpo contiene una memoria afectiva de los hechos traumáticos vivenciados. En este sentido ha sido utilizado como material en las distintas prácticas de resistencia cultural en Argentina y el Cono Sur. Tanto el cuerpo íntimo como público tiene la capacidad de generar, por medio de una performance, una "conducta restaurada" y elaborar, de esta manera, el trauma padecido. Por último, los objetos representan un lugar importante para los exiliados: han estado acompañando los cambios de territorio y los procesos identitarios, especialmente en la segunda generación. Reponen, en cierta manera, "lo que está lejos" en un país extranjero, ya sea la familia, los amigos, el hogar o "lo argentino". Los objetos generan un lazo con el país de origen tanto para los adultos que rememoran y añoran la familia, como para los niños 
que, incluso, "conocen", a través de ellos, lo lejano. Asimismo, en un movimiento parecido en el retorno de los exiliados argentinos, los objetos mexicanos condensan las memorias del país receptor.

Dentro de estas especificidades del medio artístico elegido -lo fotográfico, lo corporal y lo objetual- para trabajar una determinada memoria, encontramos, a su vez, características que cruzan de forma transversal gran parte de las producciones artísticas analizadas en esta tesis. Estas obras participan en una dimensión de lo ritual; elaboran un duelo íntimo, familiar y/o colectivo, y transmiten sus memorias hacia toda la comunidad. A partir de esto, intentaremos, en estas palabras de cierre, plantear ciertas relaciones entre el ritual, el duelo y lo artístico, pensando nuevas preguntas más que conclusiones finales.

El carácter ritual evocado en varias de las producciones artísticas -Fotos Lavadas, Tres Bellas Heridas, Árbol del desexilio, Fotos Tuyas- tiene una íntima relación con el tipo de objetos que presentan. Las fotografías del álbum familiar, las de tipo carnet de los desaparecidos o los objetos que han acompañado a los exiliados son objetos-restos, soportes de las memorias que quedaron, tienen un valor testimonial tanto del exilio político como de la desaparición forzada de personas. En estas prácticas poético-testimoniales se coloca, entonces, a estos restos en un escenario que evoca al ritual -visible en el espacio señalizado en algunos casos o en el cuerpo performático en otros-, generando una mirada sacralizada sobre los objetos testimoniales y poniendo en primer lugar la unión entre el presente de las personas y el pasado de esos objetos -es importante aclarar que, como ya vimos, esta dimensión de lo ritual no agota o encapsula el significado de las obras, sino que aparecen múltiples miradas que sobrepasan lo "sagrado" como, por ejemplo, en el caso de Fotos Tuyas de Inés Ulanovsky.

Ahora bien, ¿qué relación hay entre el ritual y el duelo? Si bien este tema es muy extenso y no es nuestro objetivo desarrollarlo, sólo nos interesa recordar que el carácter sagrado de las imágenes existe desde el origen mismo de la creación de imágenes en el culto a los muertos. En dicho ritual, se intercambiaba el cuerpo efímero del difunto por una imagen para que éste pudiera permanecer "presente" entre los vivos. ${ }^{139} \mathrm{Se}$ generaba, entonces, un intercambio simbólico entre muerte e imagen, y, como afirma Belting: "[a]sí en este caso no se trataba únicamente de un medio entre imagen y

\footnotetext{
139 Cfr.: "En consecuencia, la imagen de un muerto no es una anomalía, sino que señala el sentido arcaico de lo que la imagen es de todos modos. El muerto será siempre un ausente, y la muerte una ausencia insoportable, que, para sobrellevarla, se pretendió llenar con una imagen.” (Belting, 2012, p. 178).
} 
espectador, sino entre muerte y vida." (2012, p. 38). ${ }^{140}$ El difunto, a través de la imagen, intentaba sobrellevar la ausencia insoportable que es la muerte. Además de este sentido simbólico arcaico del origen de las imágenes, otra característica del ritual es justamente que habilita el pasaje de una cosa en otra, una transformación de carácter ontológico, como afirma Belting: "En concepciones mágicas (...) encontramos la reveladora praxis de consagrar a los medios de la imagen para su uso en un lugar aislado, transformando, en primer lugar, una sustancia en un medio a través de un ritual" (2012, p. 17).

Estas dos ideas sobre el ritual, la de su origen en el culto a los muertos y la de transformar una cosa en otra, nos permite pensar en la dimensión de duelo que contiene esta práctica. Didi-Huberman nos cuenta, a partir del análisis de los exvotos, cómo la transformación que se genera en un ritual muchas veces tiene que ver con lograr una sanación o un duelo: "Antes de representar a alguien, el exvoto representa el síntoma y el rezo de alguien: lo que el donante hace modelar en la cera es, ante todo, aquello que le hace sufrir y aquello que desea que se transforme, se alivie, se sane, se convierta." (2013, p. 28). Si bien las propuestas artísticas que analizamos en la tesis son bien diferentes, mantienen esta capacidad de generar una elaboración del duelo a partir, en cierta medida, de la escenificación de un ritual. La performance, entendida como "conducta practicada dos veces" (Schechner, 2000), conducta restaurada o reactualizada; implica generar una transformación dado que a través de la repetición de una misma acción, se vivencia, sin embargo, una situación nueva. Esto se corresponde con el pasaje del acting out a la elaboración. (LaCapra, 2008). En Tres Bellas Heridas se puede ver el carácter de ritual de duelo como una forma de sanación y de "reparación", en cierto sentido, de ese dolor. De la acción repetitiva del tatuador y las máquinas de coser surgen las "bellas heridas" que elaboran el trauma familiar. Asimismo, en las otras producciones visuales, los objetos-restos, objetos testimoniales son recontextualizados y, de esta manera, transformados en otra cosa: en Fotos Lavadas se escenifica un ritual con un círculo de sal y el uso del blanco en la vestimenta de la artista, y se entregan al público las fotos del álbum familiar alteradas, en Árbol del desexilio se colocan los objetos que han acompañado a los exiliados en diálogo con el anclaje a una tierra en particular, en una clara evocación a los rituales populares mexicanos.

\footnotetext{
140 “(...) una imagen encuentra su verdadero sentido en representar algo que está ausente, por lo que sólo puede estar ahí en la imagen; hace que aparezca algo que no está en la imagen, sino que únicamente puede aparecer en la imagen.” (Belting, 2012, p. 178).
} 
Entonces, nos preguntamos nuevamente cuál es el papel del arte en todo esto. Boris Cyrulnik, neurólogo, psiquiatra y psicoanalista, nos dice que el arte es una de las mejores vías para elaborar el trauma, para desarrollar la resiliencia: "En Ruanda después del genocidio, hacen poesías...es el único medio que tienen de decir lo que les ha pasado. Si contaran lo que les pasó, es tan horrible, que todo el mundo se pondría a llorar y les dirían que se callaran ("venga, para ya, la guerra ha terminado")" y continúa "La poesía, la obra de teatro o el dibujo se convierten en un acto de liberación porque les permiten compartir con otros lo que les pasó, pero controlando las emociones." (2009, p. 45). Del latín resilire -volver a entrar saltando o rebotar-, la resiliencia es la capacidad que tenemos para afrontar un evento traumático o situación adversa y salir fortalecidos a partir de esa experiencia. En los casos que abordamos la resiliencia tiene que operar, principalmente, sobre la dualidad identitaria en relación a la experiencia del exilio y sobre las memorias traumáticas familiares ligadas a la desaparición, en muchos casos, de algún familiar ${ }^{141}$. Este mismo concepto es utilizado por Luciano Alonso en relación a los organismos de derechos humanos, especialmente en H.I.J.O.S. Santa Fe: "[La] necesidad de clarificación y socialización de lo ocurrido es en sí misma parte del duelo, porque implica de alguna manera volver a pasar por el dolor, pero al mismo tiempo es el modo en el cual se hace factible transformar la angustia en acción y llegar a los demás.” $\left(2011\right.$, p. 226) ${ }^{142}$. Si confrontamos esta mirada sobre H.I.J.O.S. Santa Fe con las producciones artísticas que analizamos en la tesis -teniendo en cuenta las distintas memorias traumáticas que aparecen en uno y otro caso- podemos ver que la vía artística contiene estas dos dimensiones: por un lado posibilita un duelo personal, familiar y/o colectivo impulsado por medios artísticos específicos que favorecen el trabajo con la memoria traumática -lo fotográfico, lo corporal y lo objetual- y, por otro

\footnotetext{
${ }^{141}$ Con respecto a las problemáticas de la primera generación, Soledad Lastra -citando a Maletta et al (1986)- trae el concepto de transiliencia del migrante: “(...) la integración económica y la significativa aculturación cognitiva con el país de residencia no parecen ser suficientes para detener la desición de volver, ya que resulta dificultosa su identificación con la sociedad de asilo.” (2013, p. 324).

${ }^{142}$ Luciano Alonso define en su capítulo el concepto de resiliencia: “(...) proviene de la física. En la mecánica, puede ser definida como propiedad de la materia que se opone a la rotura por el choque o percusión, o el índice de resistencia al choque de un material. Se aplica también a la capacidad de un cuerpo o de un material para recuperar su forma original, aludiendo a su elasticidad. En los últimos años se ha extendido su uso en el campo de la psicología - muchas veces de manera banal- recuperando las dos dimensiones del concepto provenientes de la física: por un lado, la resistencia que los sujetos presentan ante problemas serios o situaciones constantes que pueden poner en grave riesgo o incluso destruir la integridad psíquica, por el otro, la capacidad para reconstruir la propia interioridad y la relación con los demás a pesar y a través de las adversidades, fortaleciéndose por medio de la experiencia. En la aceptación psicológica del término que popularizó Boris Cyrulnik, equivale a "resistencia al sufrimiento" y señala tanto la resistencia a la herida psicológica como el impulso subsiguiente de reparación psíquica". (2011, p. 221).
} 
lado, transmiten y socializan esas memorias al resto de la comunidad en un espacio público. Además de desarrollar la resiliencia por medio de la práctica artística, hemos visto como muchos de ellos también se organizaron políticamente en el exilio con la JAE y luego en Argentina como Hijas e Hijos del Exilio.

En este punto, nos parece importante destacar que el duelo, además de ser personal y familiar, es colectivo y político ${ }^{143}$, dado que el arte participa en espacios públicos de la comunidad. Es necesario, entonces, pensar tanto en la dimensión afectiva de la trasmisión de esas memorias traumáticas como en el costado más político en la socialización de las imágenes que se construyen con estas producciones. En este sentido, citamos dos preguntas de LaCapra que nos parecen centrales: en primer lugar, “ ¿dispone la sociedad moderna de adecuados rituales públicos que puedan colaborar para reconciliarnos con la melancolía y emprender procesos de duelo regenerativos, aun cuando en casos extremadamente traumáticos una concepción idealizada de una recuperación plena pueda llevarnos por un mal camino?” y, en segundo lugar, “¿quién será el que hará duelo y cómo puede especificarse su objeto de modo que sea éticopolíticamente deseable y efectivo para reducir la angustia a límites tolerables?” (2008, p. 227) ${ }^{144}$.

Se vuelve fundamental, entonces, pensar a estos artistas como actores sociales o emprendedores de la memoria (Jelin, 2012)- que llevan a cabo un duelo colectivo en un contexto específico, actual. Se torna tan importante el pasado como el presente, en este sentido se da un pasaje del hijo que es "víctima" y/o "afectado" a un ciudadano que participa en la comunidad desde el lugar de artista. Recordemos que las producciones analizadas fueron realizadas a partir del 2001. Es, también, un corrimiento del lugar del hijo/a ligado de forma "melancólica" a la militancia de sus padres, al lugar de las

\footnotetext{
${ }^{143}$ Esta traspolación de conceptos psicoanalíticos al campo de la historia y la memoria, lo trabaja LaCapra en su libro: “(...) ciertos conceptos psicoanalíticos claves (como los de transferencia, negación, resistencia, represión, acting-out y elaboración) son cruciales en el intento de dilucidar la relación entre culturas que entran en contacto así como la que se establece entre el presente (incluyendo al analista) y el pasado. Un objetivo explícito de este libro es consolidar un vínculo más fuerte entre psicoanálisis e historia en el que la relación entre individuo y sociedad no se considere como analógica a partir de las ideologías vigentes. El proceso al que refieren los conceptos básicos del psicoanálisis atraviesa la oposición entre individuo y sociedad en la medida en que abarca individuos sociales cuya individualización relativa o estatus colectivo debe ser un problema para la investigación y la reflexión. (2008, p. 25).

${ }^{144}$ En este sentido, LaCapra establece la relación entre el discurso historiográfico y el ritual: "En la medida en que el discurso historiográfico pueda alcanzar válidamente una dimensión ritual sin sacrificar su naturaleza crítica, puede también ayudar de modo restringido a facilitar procesos públicos y garantizados de duelo. Finalmente, puede señalarse que la idea de un lenguaje adecuado -en realidad, un ritmo aceptable entre lenguaje y silencio- que trate de dar cuenta de ciertos fenómenos depende del ritual tanto como de criterios estéticos." (2008, p.229).
} 
propias formas políticas desarrolladas por la generación atravesada por el 2001. Para corrernos, entonces, de esta mirada "nostálgica", se vuelve indispensable considerar a estos hijos tanto hijos de sus padres de los 70 como hijos del período 2000-2002 en el contexto de lucha social generalizada en Argentina. Esto lo vimos claramente en el caso de la trayectoria de Magdalena Jitrik y su accionar en el Taller Popular de Serigrafía, quien afirma que:

Es la batalla cultural donde siempre hay un sector que va a decir que todo proyecto emancipador fracasó. Entonces van a decir que no sólo que es nostálgico cualquiera que revisita las vanguardias, como el que hace algún tipo de referencia a las revoluciones y siempre te dan una palmadita en la espalda y dicen aliviados que Marx se equivocó, que no pasó lo que podría haber pasado. Y luego todas distintas versiones así posmodernas. Entonces yo no pienso así, digamos yo estudio el pasado, lo visito y lo recreo de algún modo, lo traigo al presente, porque considero que la historia no se terminó. Con las insurrecciones en el 2001 yo tenía una exposición colgada que se llamaba Socialista, y todas las notas que salieron apuntaban que: "ante el fin de las utopías aparece Magdalena que..." y siempre creyendo que no iba a haber una fisura en el presente y en el mismo día ese cayó el gobierno, hubo barricadas en Buenos Aires. Entonces yo en vez de ser una nostálgica más bien estuve en el futuro inmediato, ¿no? Incluso después hubo una exposición en la que participé que hizo Marcelo de la Fuente y Valeria Gonzáles que se llamaba así, Futuro inmediato. El fin de las utopías quedó entre paréntesis en esos años, como asombrada la gente se veía que se podía salir a la calle y a generar un cambio. (...) Luego volví en el 2000 y ahí ya empecé a sentir algo mucho más interesante. Lo vi con mis propios ojos en el 2001. Entonces todos aquellos que hablan de nostalgia es porque se quieren hacer los boludos. (2015, s/p.).

Insistimos, entonces, en que estas producciones artísticas, además de elaborar los traumas colectivos pasados ligados al terrorismo de estado argentino, operan sobre una realidad actual, presente y con modos propios desarrollados por la segunda generación. Creemos que "volver a entrar saltando", si bien es una de las acepciones de resiliencia en latín, alude a esa capacidad que tiene esta generación de trabajar el dolor a partir del arte y desde la coyuntura presente. 


\section{IMÁGENES}

\section{Capítulo 3: lo fotográfico y la memoria}

\section{Fotos lavadas (2005-2010) de Soledad Sánchez Goldar}

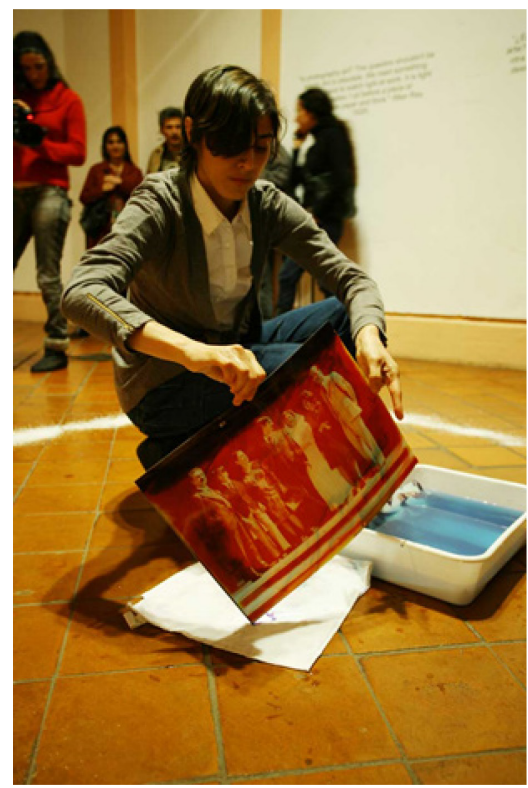

Imagen 1. Soledad Sánchez Goldar en la performance Fotos lavadas presentada en la exposición Sostener el vacio, CCEC, Córdoba, 2008. Curaduría: Marcela López Sastre. Fotografias de Dolores Esteve.

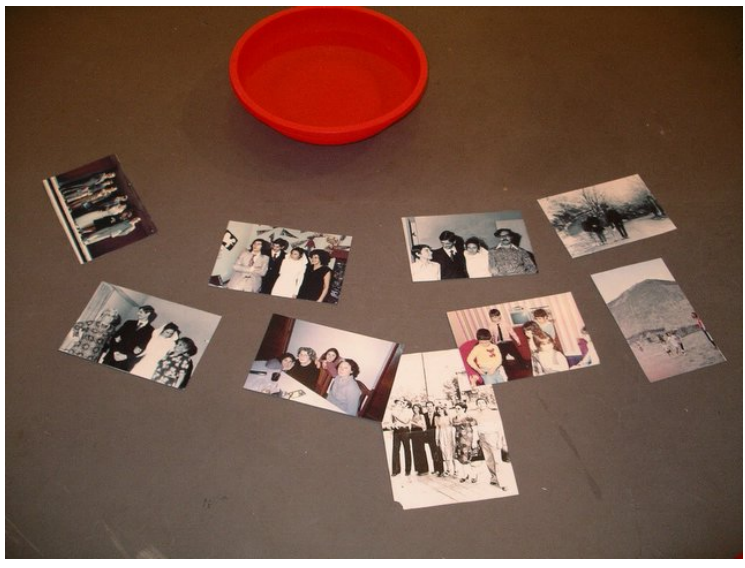

Imagen 2. Las fotografías que luego serán "lavadas" en la performance Fotos Lavadas en el Stand de Arreboles de mequetrefe, en la feria Periférica Arte de Base, CCB, Buenos Aires, 2006. Fotografía de Cuqui.

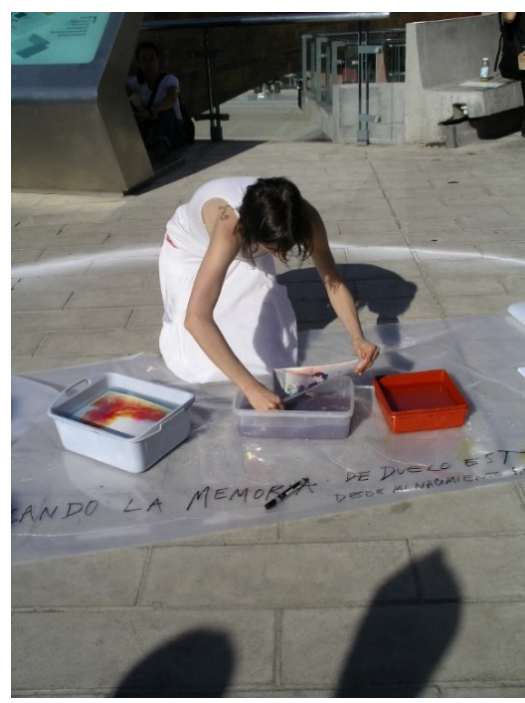

Imagen 3. Soledad Sánchez Goldar "lavando" las fotos en la Bienal Internacional de Performance Deformes, Santiago de Chile, 2006. Fotografía de Marisa Nino.

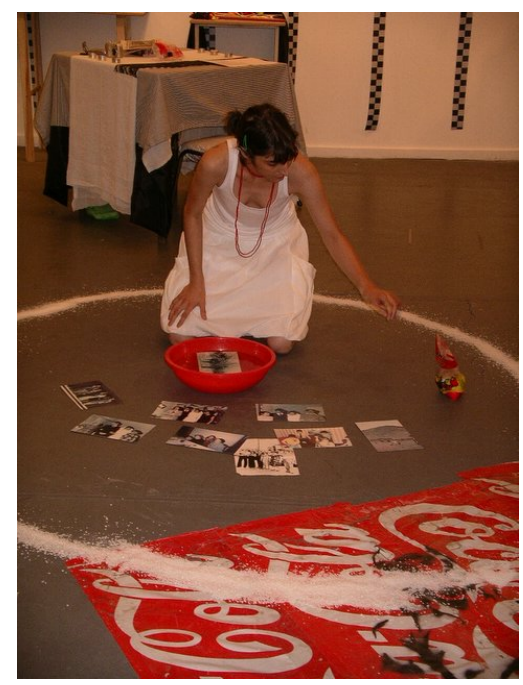

Imagen 4. Soledad "lavando" las fotos dentro del círculo de sal en el Stand de Arreboles de mequetrefe, en la feria Periférica Arte de Base, CCB, Buenos Aires, 2006. Fotografía de Cuqui. 


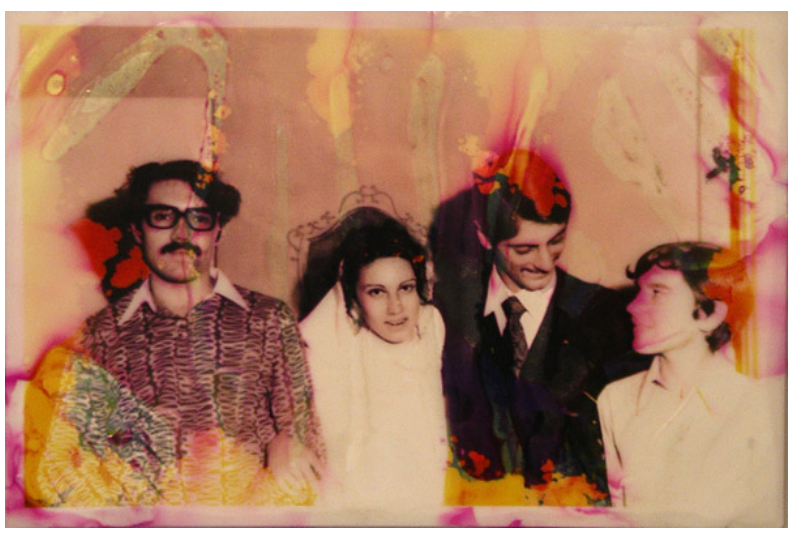

Imagen 5. Fotografía con resina de la familia de Soledad, expuesta en Fotos de Familia. Galería Espacio Centro, Córdoba, (2006). 


\section{Fotos tuyas (2006) de Inés Ulanovsky}

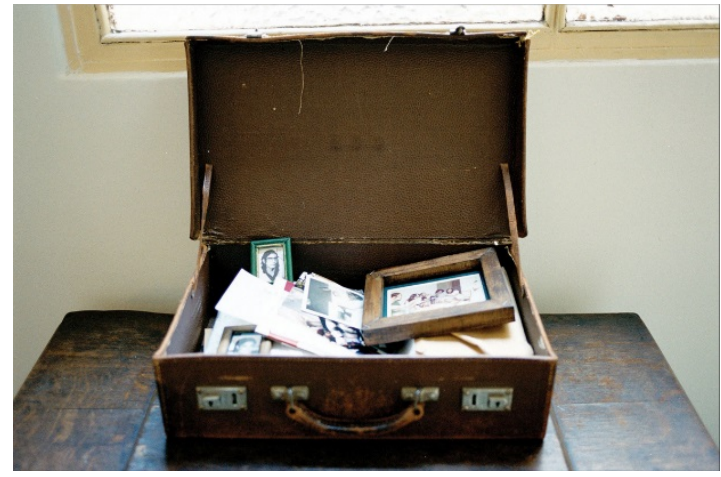

Imagen 6. Fotos Tuyas, 2006, s/p.

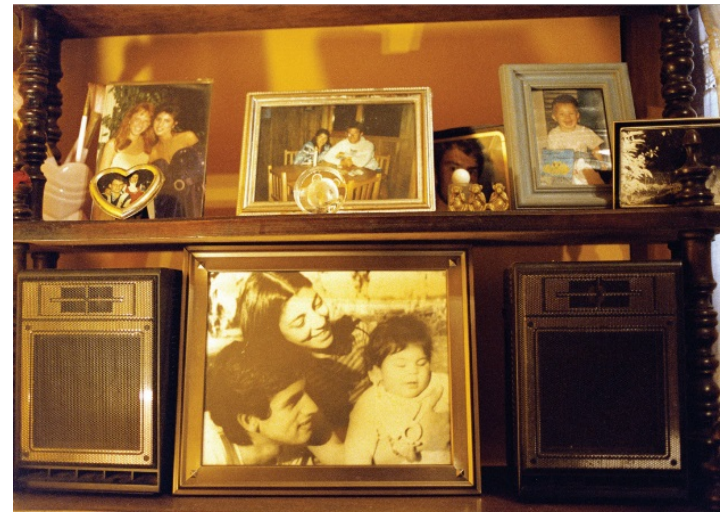

Imagen 7. Fotos Tuyas, 2006, s/p.

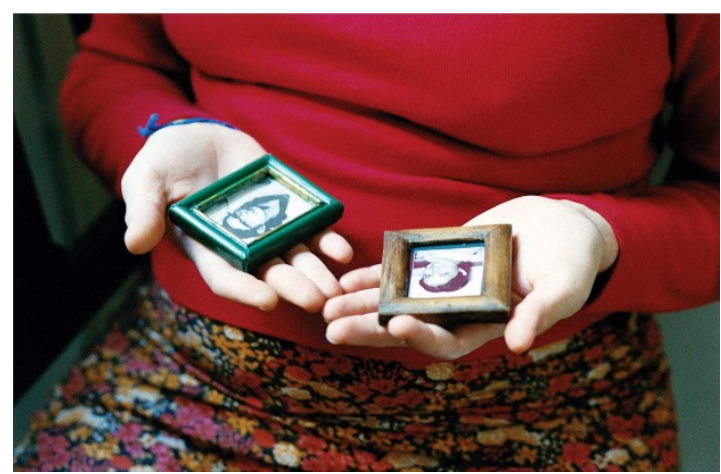

Imagen 8. Fotos Tuyas, 2006, s/p.

$$
\begin{aligned}
& \text { His herranos Gouado y Alserto } \\
& \text { desofacievon en noricurbee do } 1976 \\
& \text { Con vie trenane de difencice } \\
& \text { Nurce que cestrubsi a esa currevere } \\
& \text { Etan comuifo en bode purvento do } \\
& \text { dobory de alegie. }
\end{aligned}
$$

Imagen 9. Carta de Judith Said sobre la desaparición de sus dos hermanos, Alberto Ezequiel Said, estudiante de Ciencias Económicas y comerciante, y Jaime Eduardo Said, abogado. (Fotos Tuyas, 2006, s/p.).

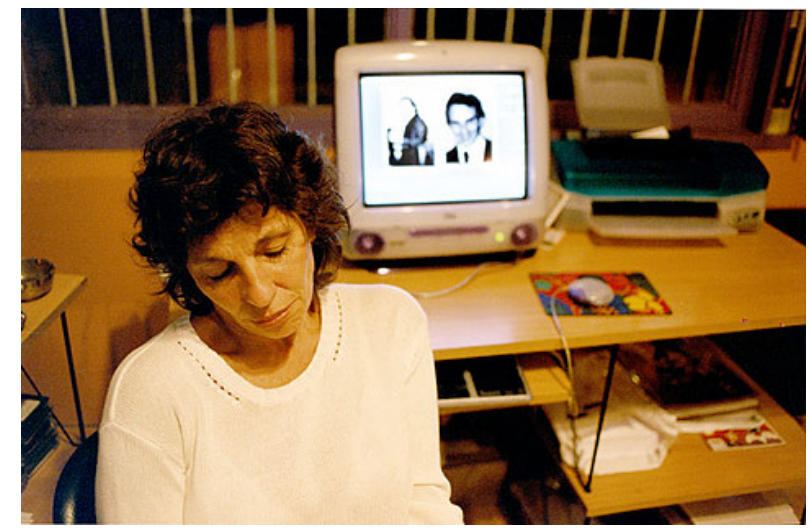

Imagen 10. Retrato de Judith Said. Al fondo, las fotografías de sus hermanos desaparecidos Alberto y Eduardo. (Fotos Tuyas, 2006, s/p.). 


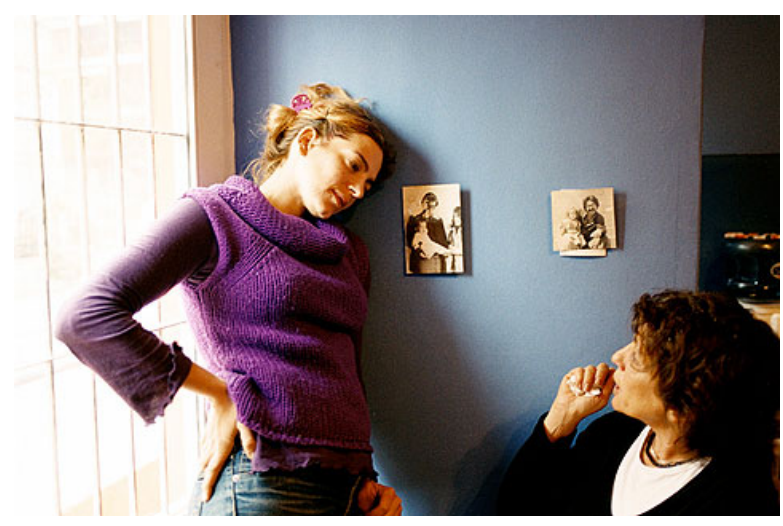

Imagen 11. María Bordesio, hija de Judith Said y de Mario Bordesio. Su padre, antropólogo y militante montonero, fue secuestrado y desaparecido en Rosario. (Fotos Tuyas, 2006, s/p.).

$$
\begin{aligned}
& \begin{array}{l}
\text { Yiipopa que secuesta do for ias juerzas armadas } \\
\text { undia de } 1977
\end{array} \\
& \text { jo nincal me hice a la idea de que no este. } \\
& \text { a recas creo que me mira dede Lejas? } \\
& \text { Por so aun muerta lo scquiria buscan slo } \\
& \text { a ei que jue lo imagen } \\
& \text { de eve sepoede siempre llegor a un Lugar mos. } \\
& \text { Maria }
\end{aligned}
$$

Imagen 12. Carta de María sobre su papá, Mario Bordesio, desaparecido. (Fotos Tuyas, 2006, s/p.).

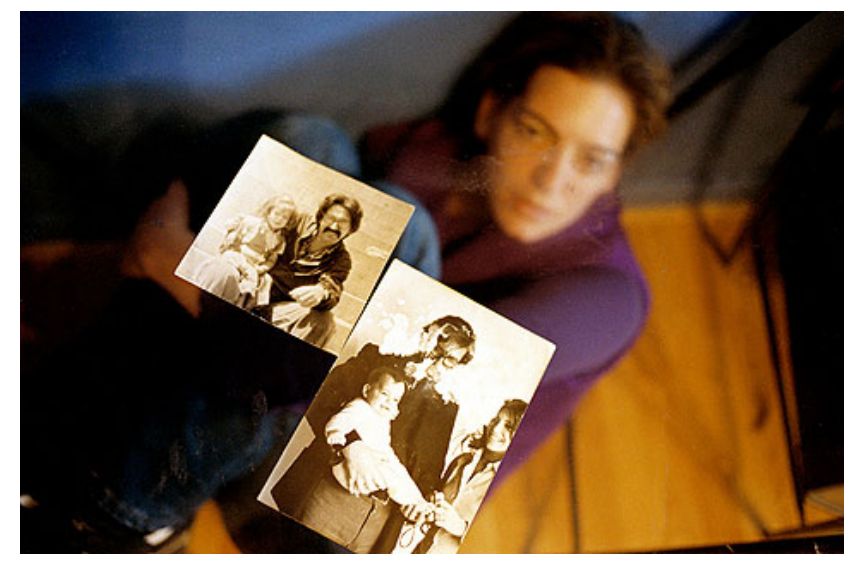

Imagen 13. Fotos familiares donde aparece Mario Bordecio, y al fondo, María. (Fotos Tuyas, 2006, s/p.).

$$
\begin{aligned}
& \text { Ricerdo Anibal Dios } \\
& \text { Mi papá. Twe aresinacb ol is de } \\
& \text { novenbre de } 1976,11 \text { dís entes de mi nacimiento. } \\
& \text { Nunce prodimos vernos a los ojos }
\end{aligned}
$$

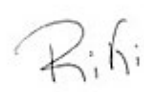

Imagen 14. Carta de Ricardo Dios, hijo de Judith Said y de Ricardo Aníbal Dios. Su papá fue militante montonero. (Fotos Tuyas, 2006, $\mathrm{s} / \mathrm{p}$.$) .$ 


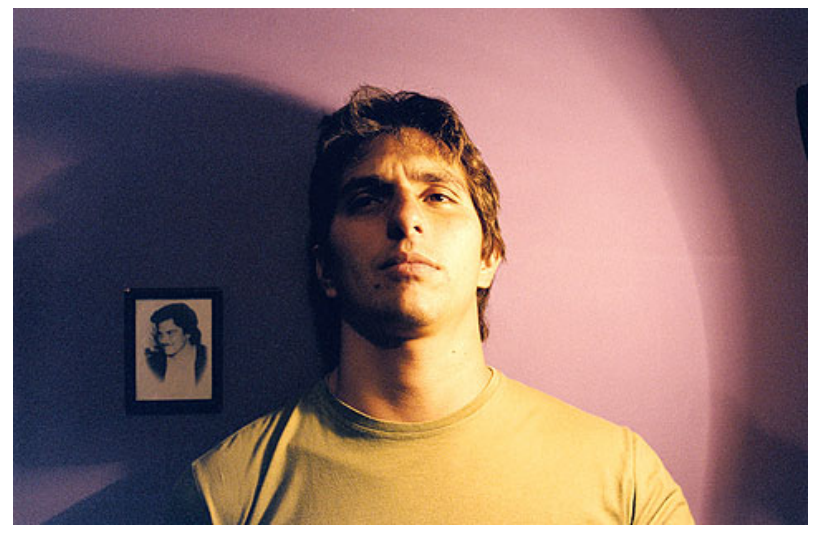

Imagen 15. Retrato de Ricardo Dios junto con la foto de su papá, Ricardo Aníbal Dios. (Fotos Tuyas, 2006, s/p.).

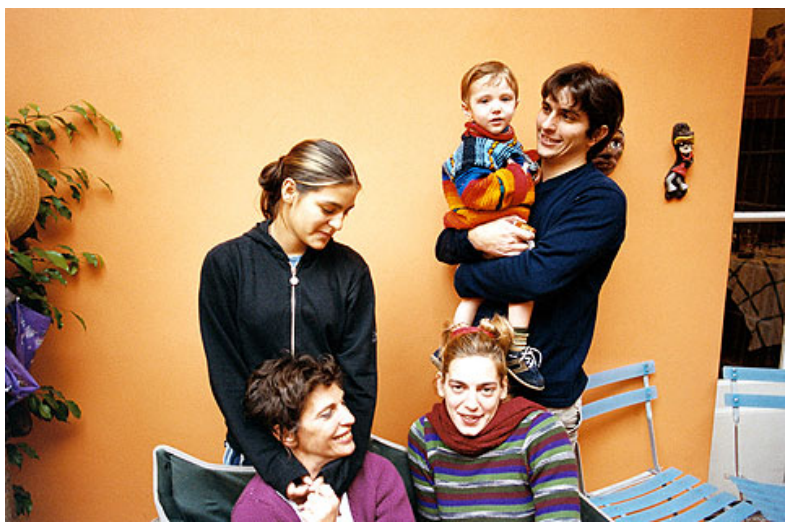

Imagen 16. Última foto de la serie "4" del libro Fotos Tuyas. (2006, s/p.). 


\section{Capítulo 4. Lo corporal y la memoria}

\section{Taller Popular de Serigrafía (2000-2007)}

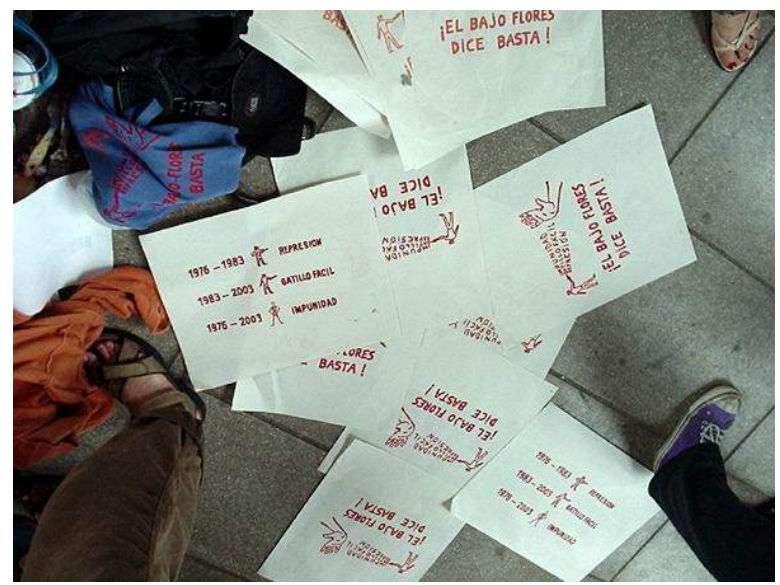

Imagen 1. TPS junto con la Mesa de Escrache Popular en el escrache a Jorge Héctor Vidal, 27 de diciembre de 2003, CABA. Fotografía de Mat - Zula (Argentina Indymedia).

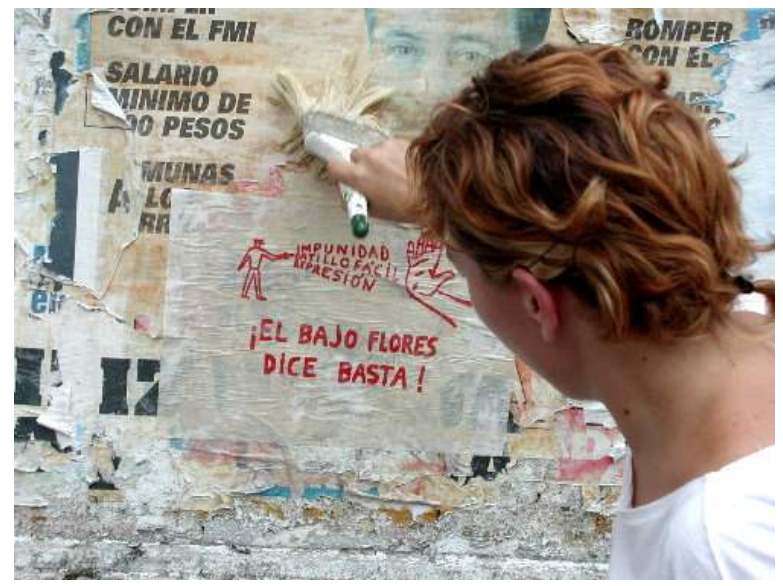

Imagen 2. TPS junto con la Mesa de Escrache Popular en el escrache a Jorge Héctor Vidal, 27 de diciembre de 2003, CABA. Fotografía de Rulo (Argentina Indymedia).

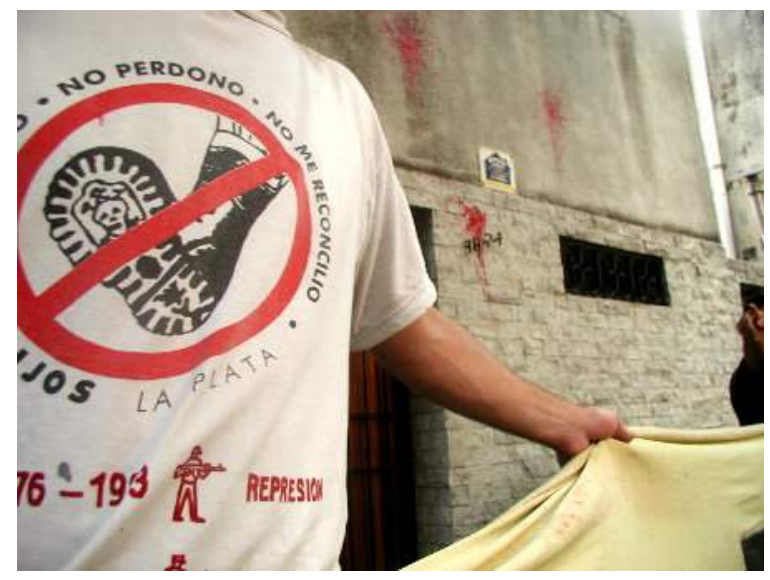

Imagen 3. TPS junto con la Mesa de Escrache Popular en el escrache a Jorge Héctor Vidal, 27 de diciembre de 2003, CABA. Fotografía de Rulo (Argentina Indymedia)

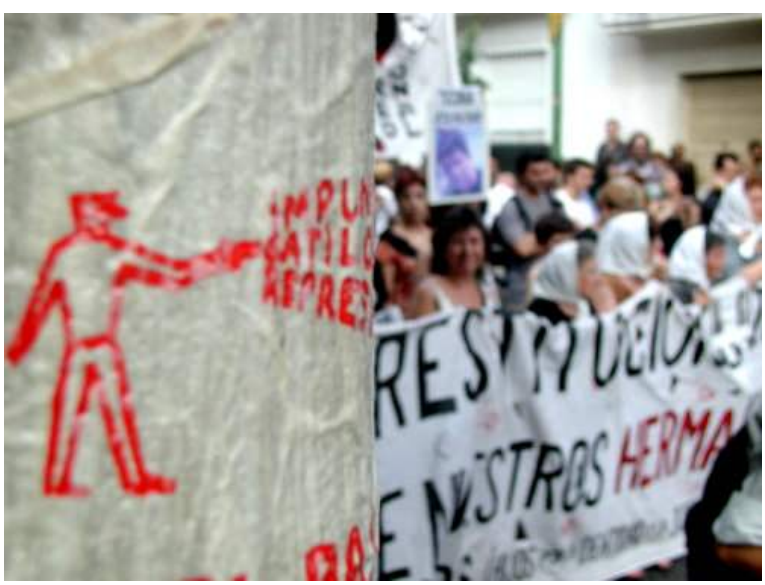

Imagen 4. TPS junto con la Mesa de Escrache Popular en el escrache a Jorge Héctor Vidal, 27 de diciembre de 2003, CABA. Fotografía de Rulo (Argentina Indymedia). 


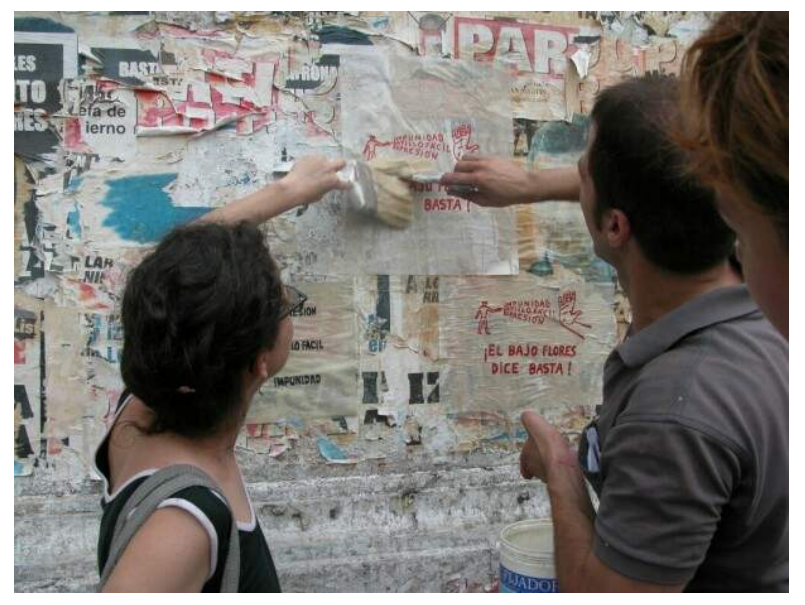

Imagen 5. TPS junto con la Mesa de Escrache Popular en el escrache a Jorge Héctor Vidal, 27 de diciembre de 2003, CABA. Fotografía de Fabio (Argentina Indymedia).

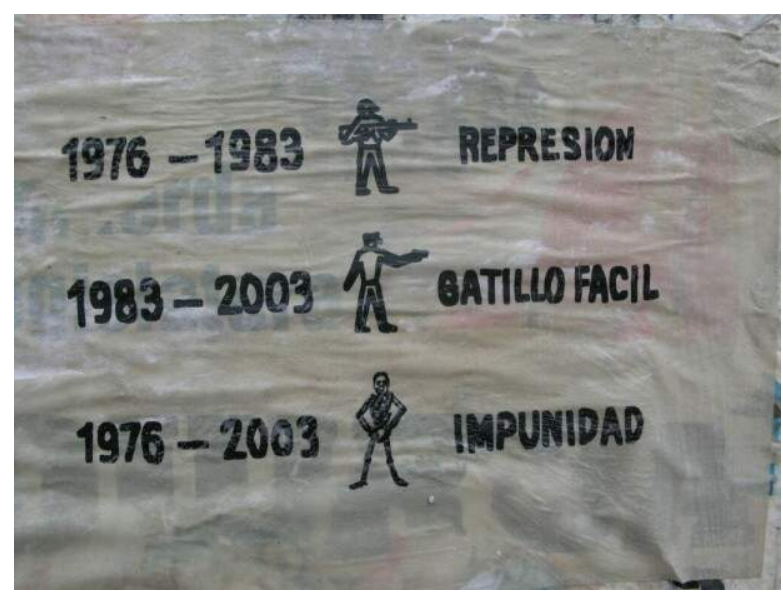

Imagen 6. Pegatina del TPS en el escrache a Jorge Héctor Vidal, 27 de diciembre de 2003, CABA. Fotografía de Fabio (Argentina Indymedia).

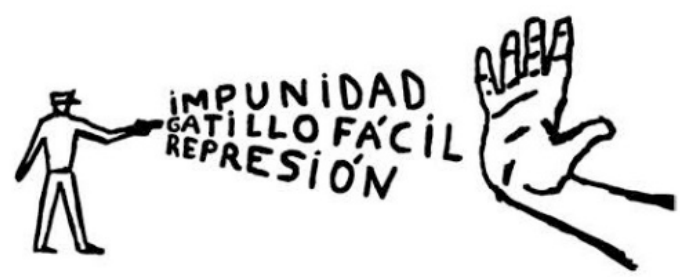

\section{¡BASTA YA!}

Imagen 7. Basta Ya, dibujo del TPS para el Escrache a Jorge Vidal 27 de diciembre de 2003, CABA. (AAVV, 2010, s/p.).

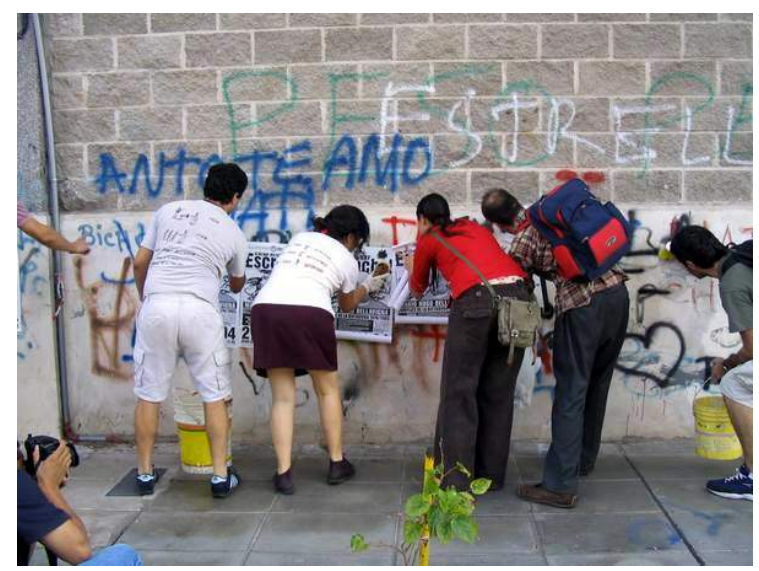

Imagen 8. TPS junto con la Mesa de Escrache Popular en el escrache a Mario Hugo Bellavigna, 27 de noviembre de 2004, CABA. Fotografía de Zula (Argentina Indymedia). 

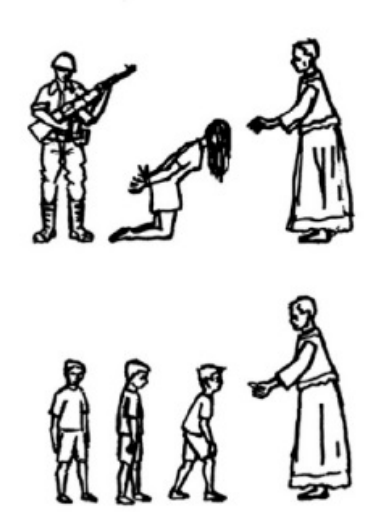

2004

\section{HUGO MARIO BELLAVIGNA}

AYER Y SIEMPRE

\section{COMPLICE DE LA TORTURA}

Imagen 9. Dibujo del TPS para el escrache a Mario Hugo Bellavigna, 27 de noviembre de 2004, CABA. (AAVV, 2010, s/p.).

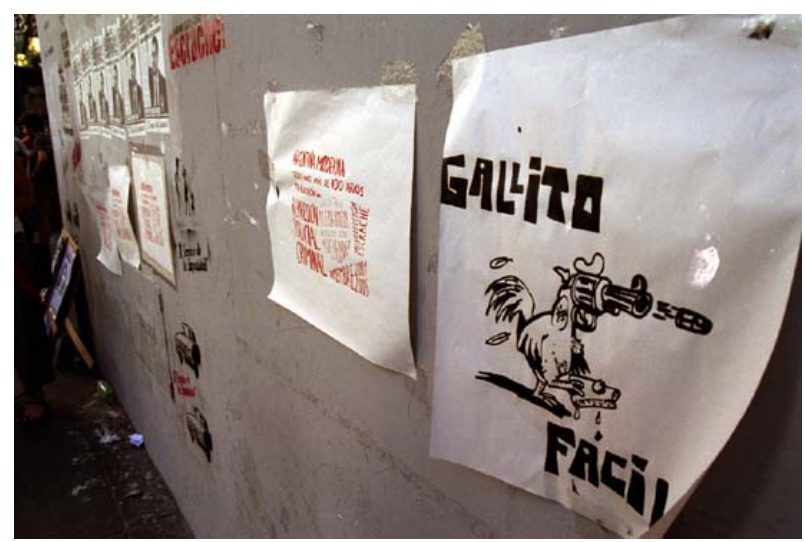

Imagen 10. TPS junto con la Mesa de Escrache Popular en el escrache a Sergio Weber, 17 de diciembre de 2005. Fotografía de Nicolás Solo (Argentina Indymedia).

\section{ARGENTINA MODERNA} DESDE HACE MÁS DE 100 AÑOS TRADICIÓN en

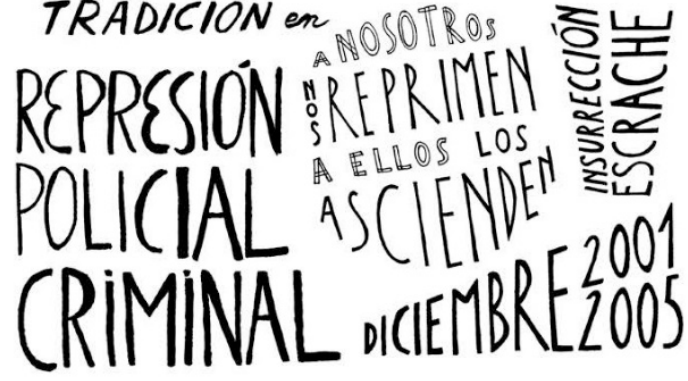

Imagen 11. Argentina Moderna, dibujo del TPS para el escrache a Sergio Weber, 17 de diciembre de 2005. Fotografía de (AAVV, 2010, s/p.). 


\section{Tres Bellas Heridas (2007) de Soledad Sánchez Goldar}

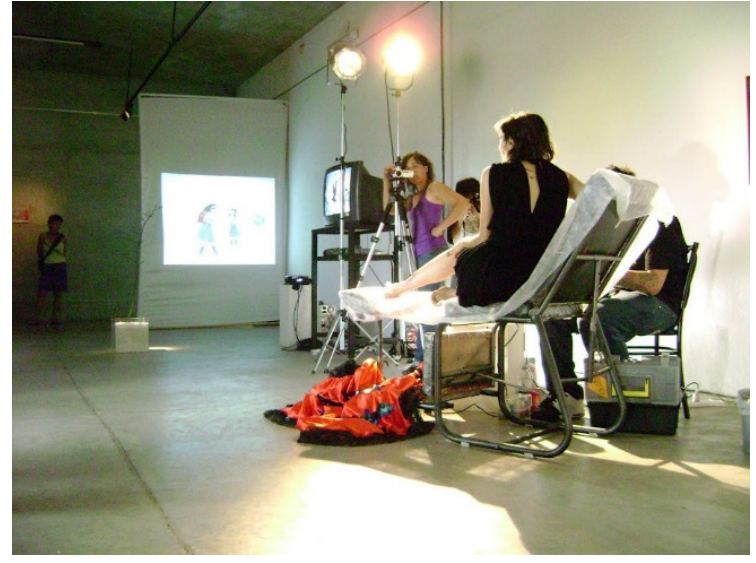

Imagen 12. Performance Tres Bellas Heridas de Soledad Sánchez Goldar, Espacio CePIA, UNC, 2007. Fotografía de Carmen Cachin.

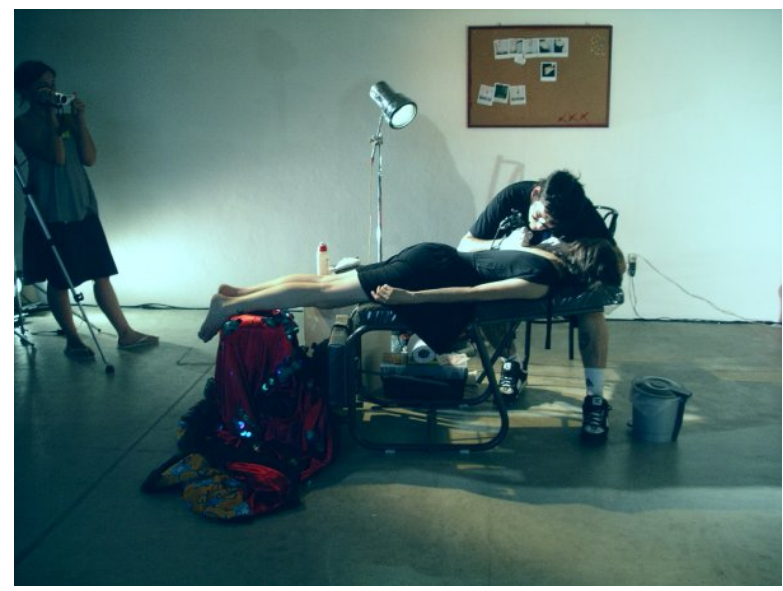

Imagen 13. Soledad siendo tatuada en la performance en Espacio CePIA, UNC, 2007 Fotografía de Carmen Cachin.

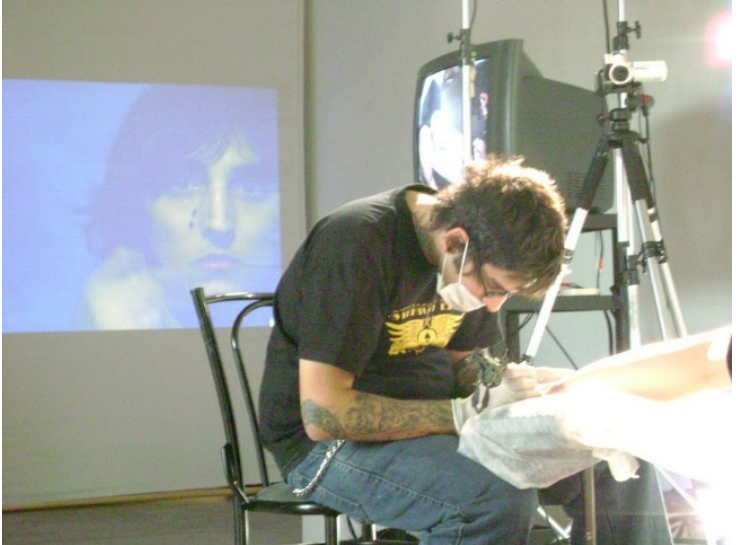

Imagen 14. Realización del tatuaje Purificación sobre el cuerpo de Soledad en la performance en el Espacio CePIA UNC, 2007. Fotografía de Carmen Cachin.

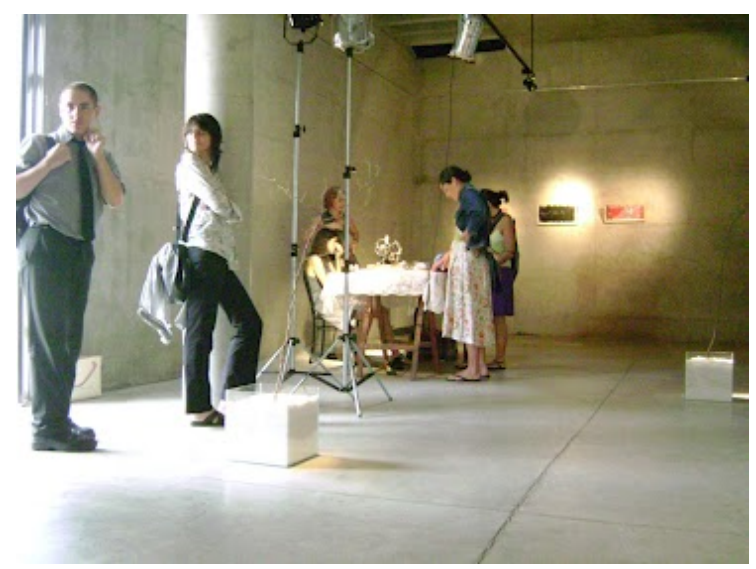

Imagen 15. Performance Tres Bellas Heridas de Soledad Sánchez Goldar, Espacio CePIA UNC, 2007. Fotografía de Carmen Cachin. 


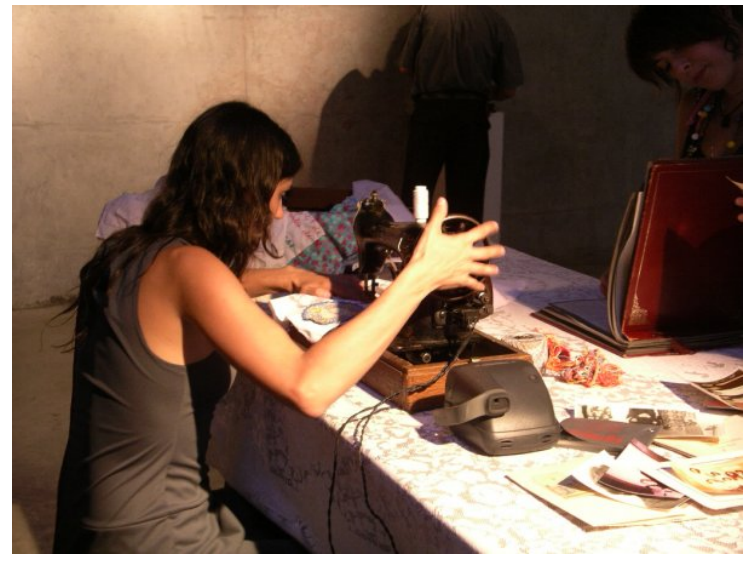

Imagen 16. Celeste Sánchez Goldar, hermana de Soledad, confeccionando el patchwork en la performance, Espacio CePIA UNC, 2007. Fotografía de Carmen Cachin.

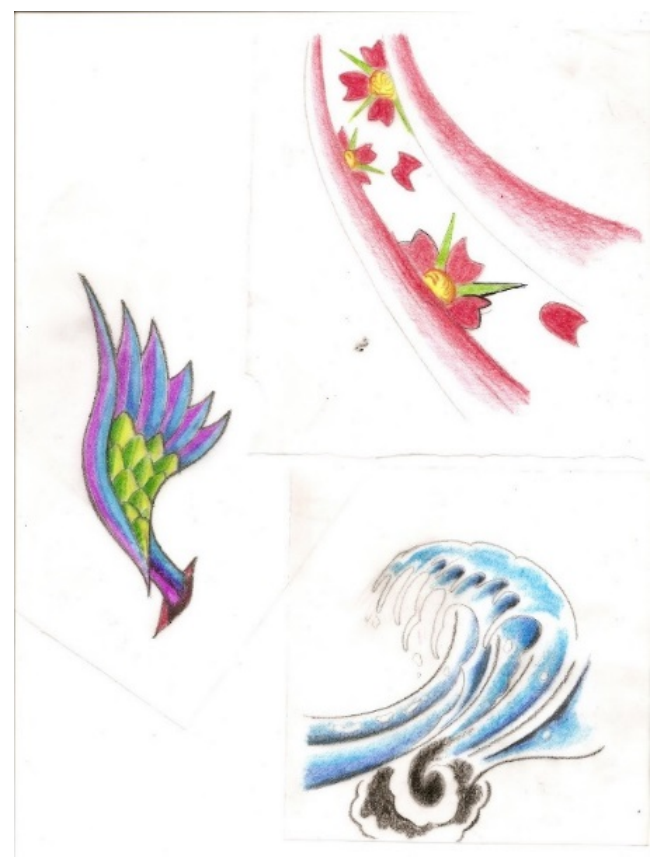

Imagen 17. Dibujo de las "tres bellas heridas".

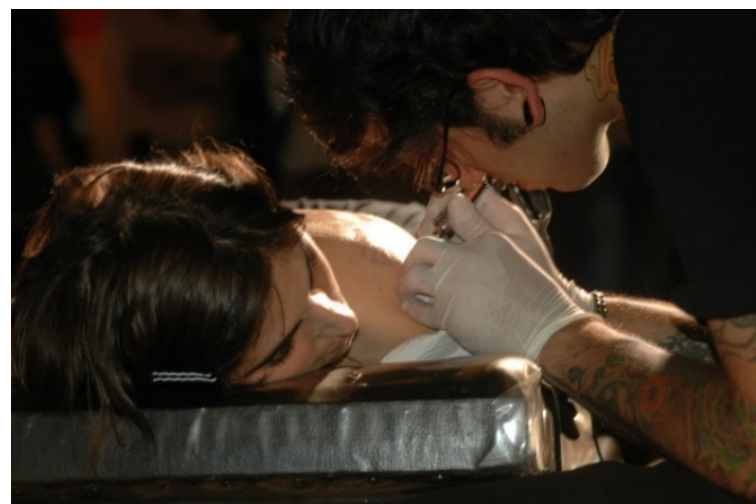

Imagen 18. Realización del tatuaje Exhalación sobre el cuerpo de Soledad en la performance, Espacio CePIA UNC, 2007. Fotografía de Carmen Cachin.

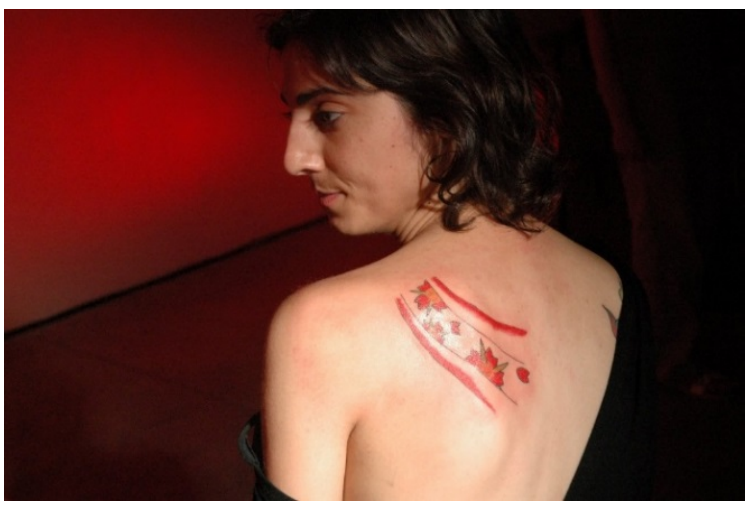

Imagen 19. Tatuaje Exhalación, realizado durante la performance en el Espacio CePIA UNC, 2007. Fotografía de Carmen Cachin.

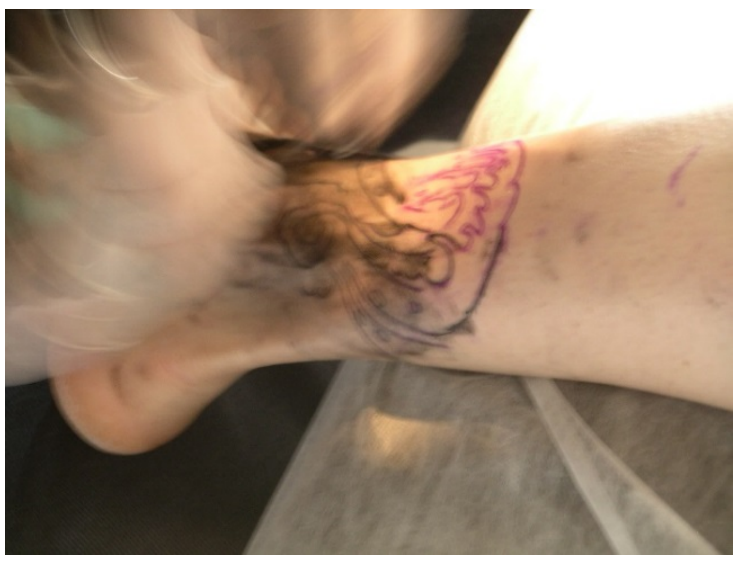

Imagen 20. Realización del tatuaje Purificación durante la performance, Espacio CePIA UNC, 2007. Fotografía de Carmen Cachin. 


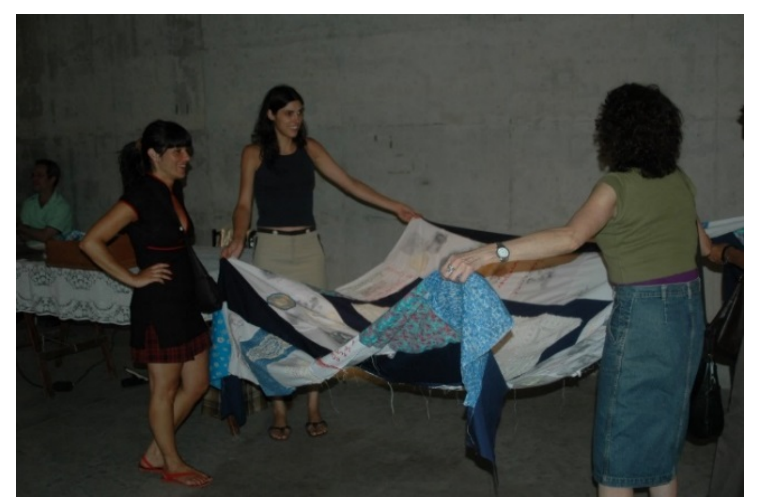

Imagen 21. Patchwork confeccionado durante la performance en el Espacio CePIA UNC, 2007. Fotografía de Carmen Cachin.

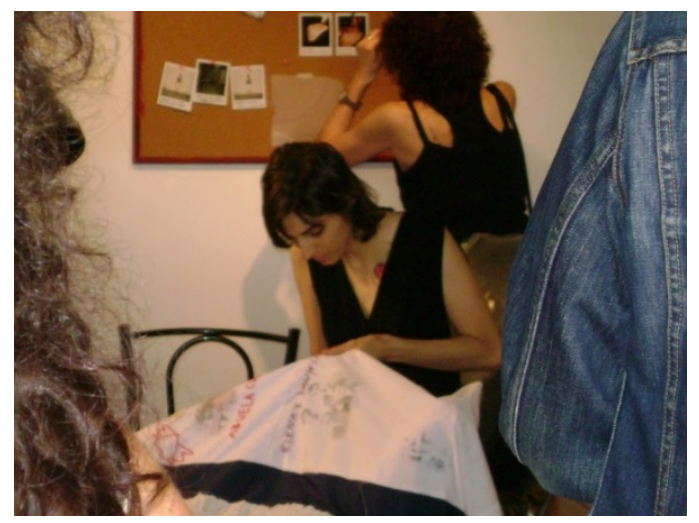

Imagen 22. Confección del patchwork durante la performance, Espacio CePIA UNC, 2007. Fotografía de Carmen Cachin.

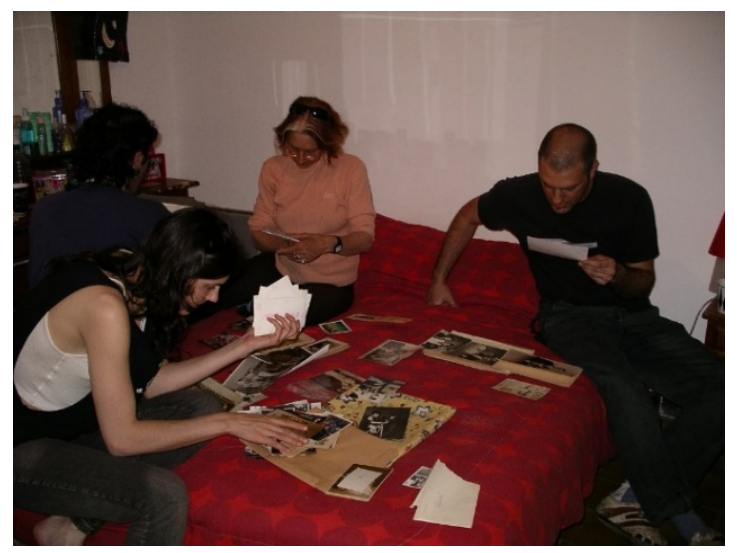

Imagen 23. Selección de fotos familiares para el patchwork realizado durante la performance, 2007. Fotografía de Carmen Cachin.

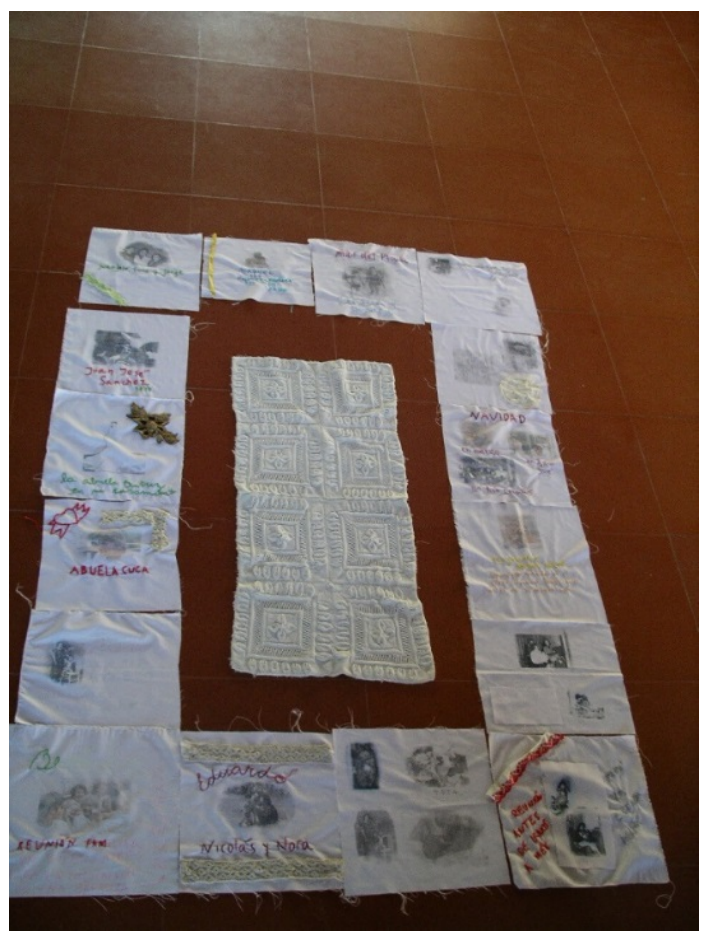

Imagen 24. Armado del patchwork en la performance, Espacio CePIA UNC, 2007. Fotografía de Carmen Cachin.

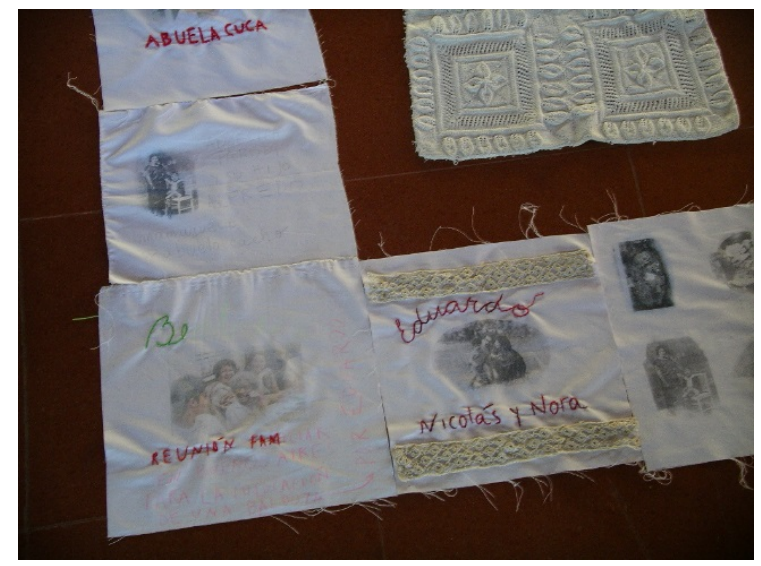

Imagen 25. Detalle del armado del patchwork en la performance, Espacio CePIA UNC, 2007. Fotografía de Carmen Cachin. 


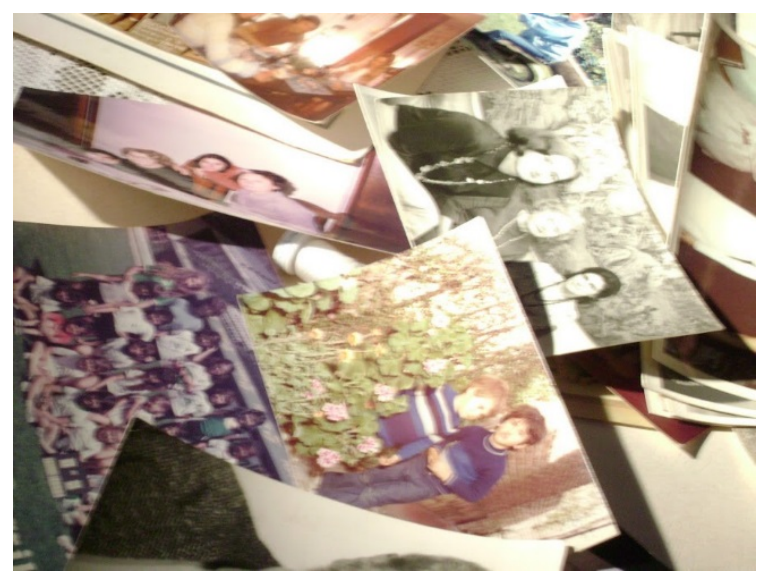

Imagen 26. Detalle de las fotografías familiares seleccionadas para la confección del patchwork de la performance, Espacio CePIA UNC, 2007. Fotografía de Carmen Cachin.

\section{Pensamiento (2010) de Soledad Sánchez Goldar}

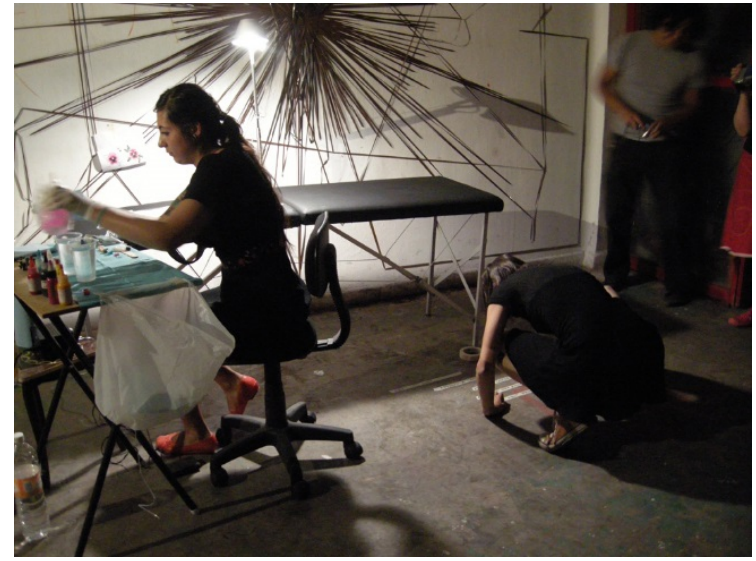

Imagen 27. Performance Pensamiento de Soledad Sánchez Goldar, Desconexiones, encuentro de Arte acción realizado en la Galería Interferencial, México DF, 2010, Fotografías de Fernanda Mejía y Miguel Sepúlveda.

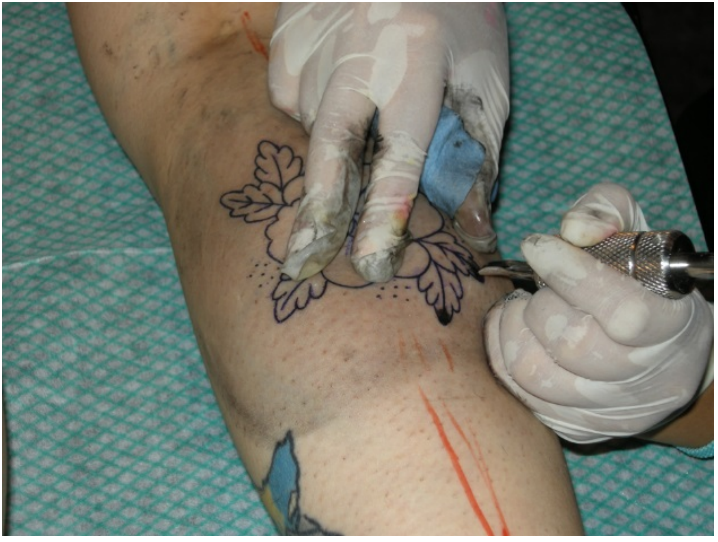

Imagen 28. Realización del tatuaje sobre el cuerpo de Soledad en la Performance Pensamiento, Galería Interferencial, México DF, 2010, Fotografías de Fernanda Mejía y Miguel Sepúlveda. 


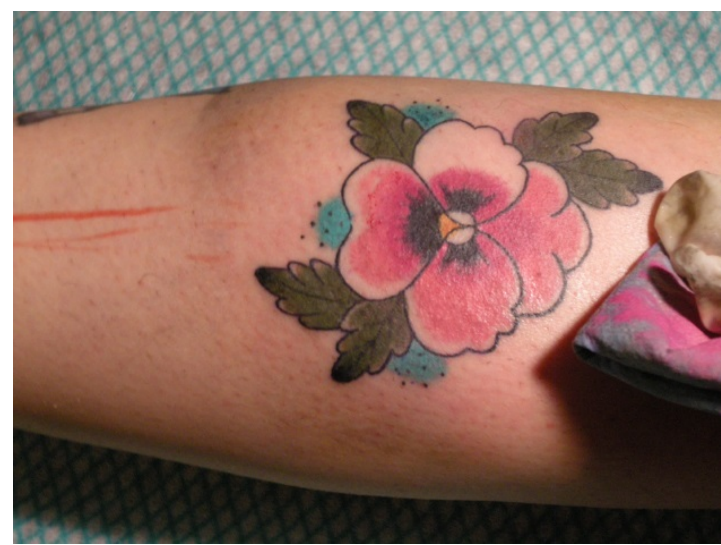

Imagen 29. Tatuaje Flor de pensamientos sobre el cuerpo de Soledad, realizado durante la performance Pensamiento, Galería Interferencial, México DF, 2010, Fotografías de Fernanda Mejía y Miguel Sepúlveda.

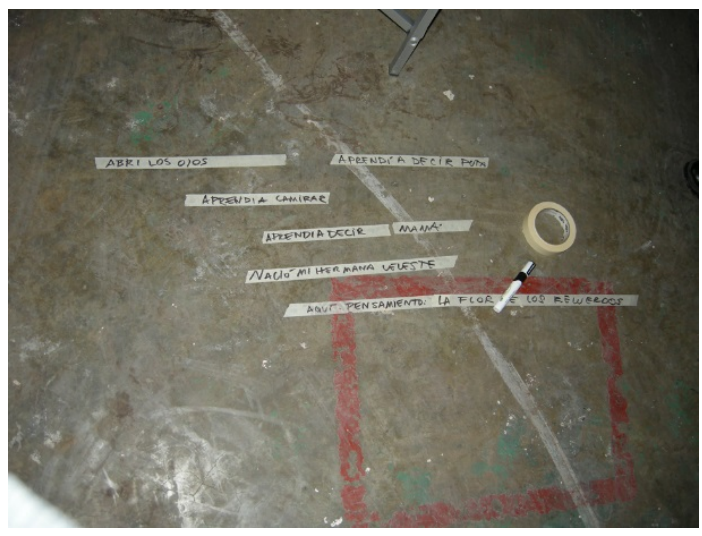

Imagen 30. Texto escrito en el piso de la galería en la Performance Pensamiento de Soledad Sánchez Goldar, Galería Interferencial, México DF, 2010, Fotografías de Fernanda Mejía y Miguel Sepúlveda.

\section{Correspondencia (2008-2010) de Soledad Sánchez Goldar}

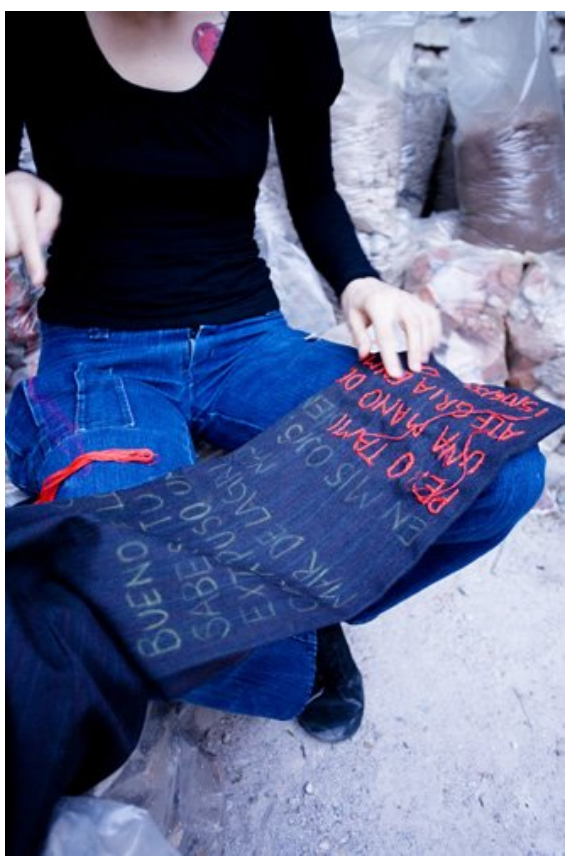

Imagen 31. Soledad bordando las palabras de las cartas durante la performance Correspondencia en el Archivo Provincial de la Memoria, Córdoba, 2010. Fotografía de Enrique Javier Díaz.

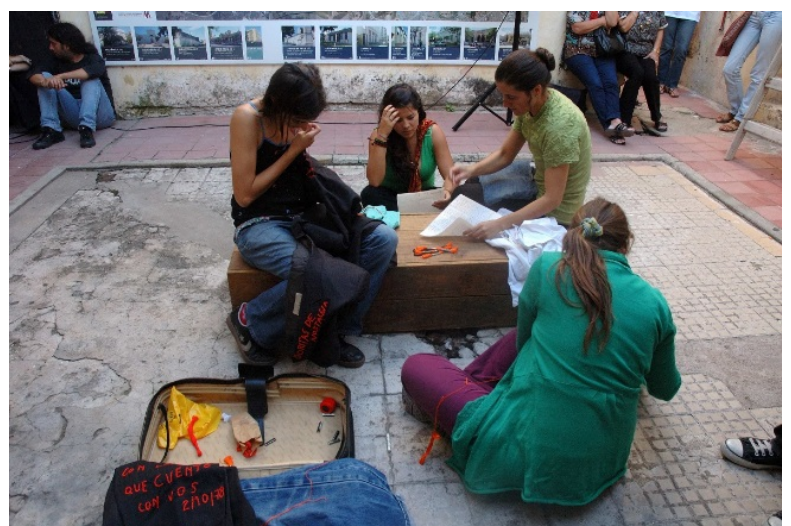

Imagen 32. Mujeres bordando -Carolina Vergara, Rosa Noto, Graciela de Oliveira, Vivie Gandra, Mara Paz- durante la performance Correspondencia en el Archivo Provincial de la Memoria, Córdoba, 2010. Fotografía de Sandra Siviero. 


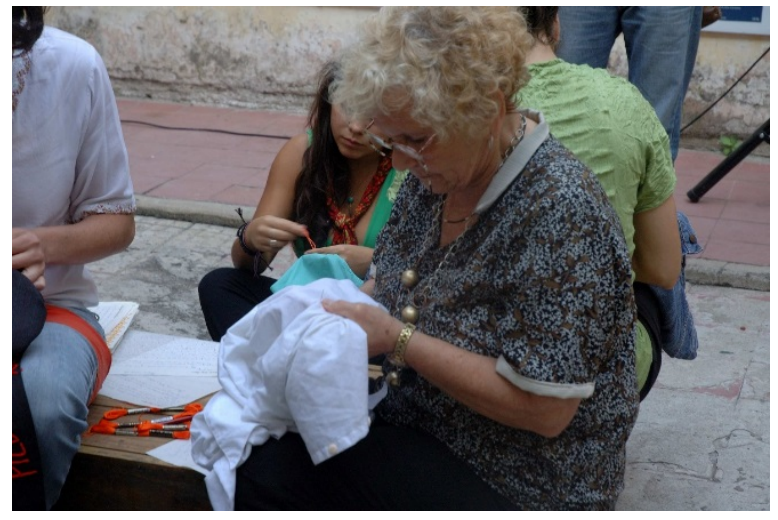

Imagen 33. Mujeres bordando -Carolina Vergara, Rosa Noto, Graciela de Oliveira, Vivie Gandra, Mara Paz- durante la performance Correspondencia en el Archivo Provincial de la Memoria, Córdoba, 2010. Fotografía de Sandra Siviero. 


\section{Capítulo 5. Lo objetual y la memoria.}

\section{Árbol del desexilio (2006-2010) de Mercedes Fidanza}

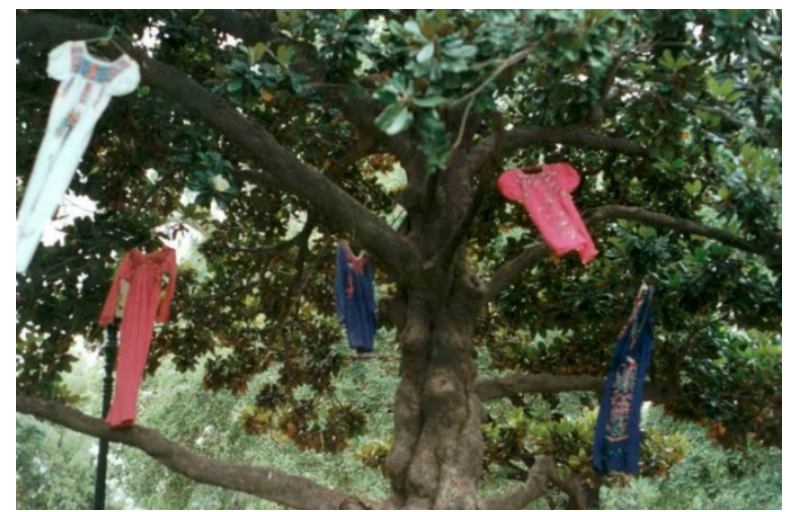

Imagen 1. Vestidos mexicanos colgando de la copa del árbol en la intervención Árbol del desexilio en la plaza de los Dos Congresos, CABA, 2006.

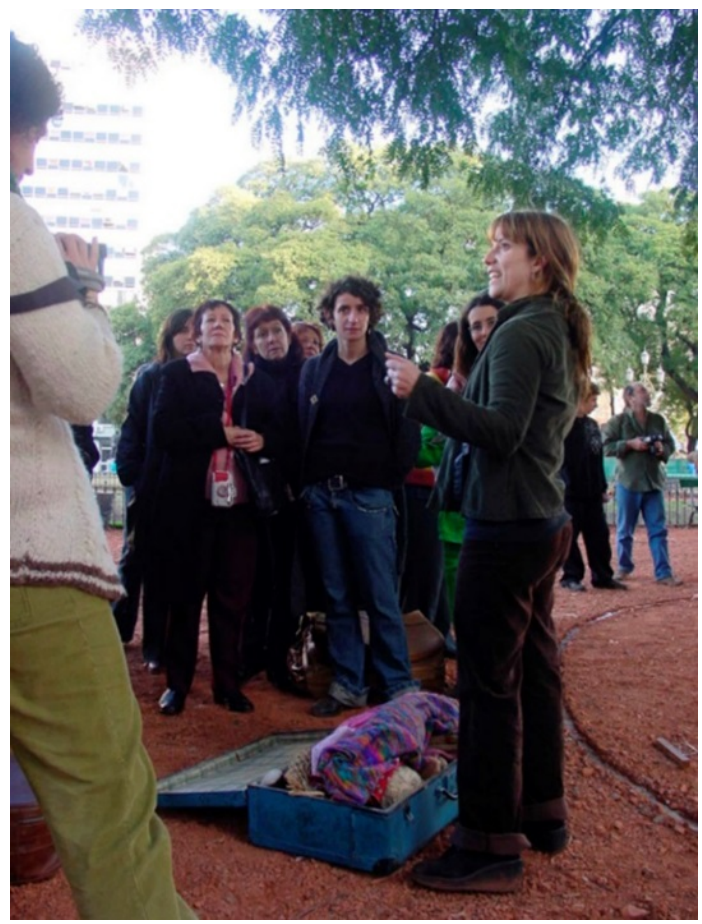

Imagen 2. Mercedes Fidanza con la valija en la intervención Árbol del desexilio en la plaza de los Dos Congresos, CABA, 2006.

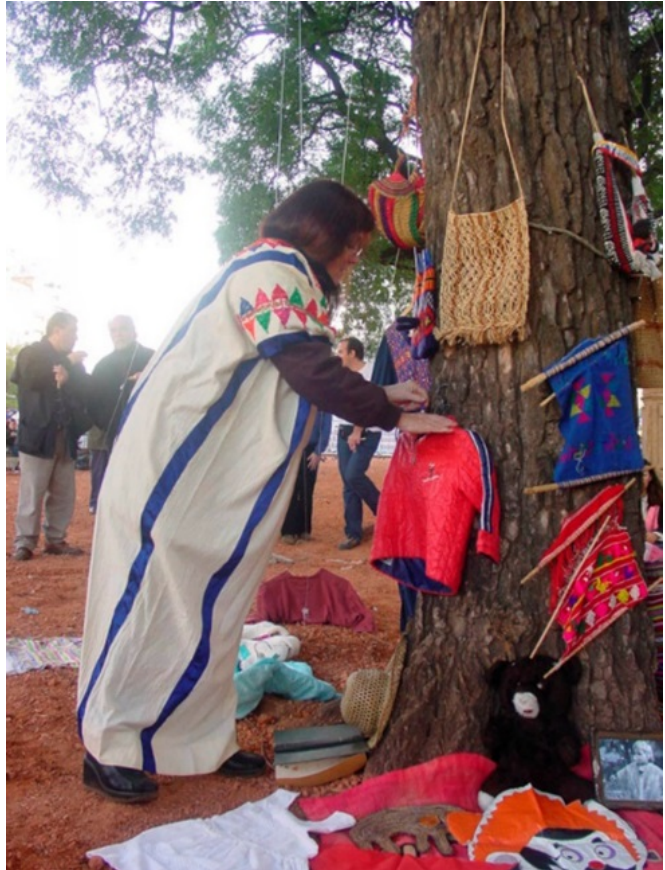

Imagen 3. Objetos de los exiliados en la intervención Árbol del desexilio en la plaza de los Dos Congresos, CABA, 2006.

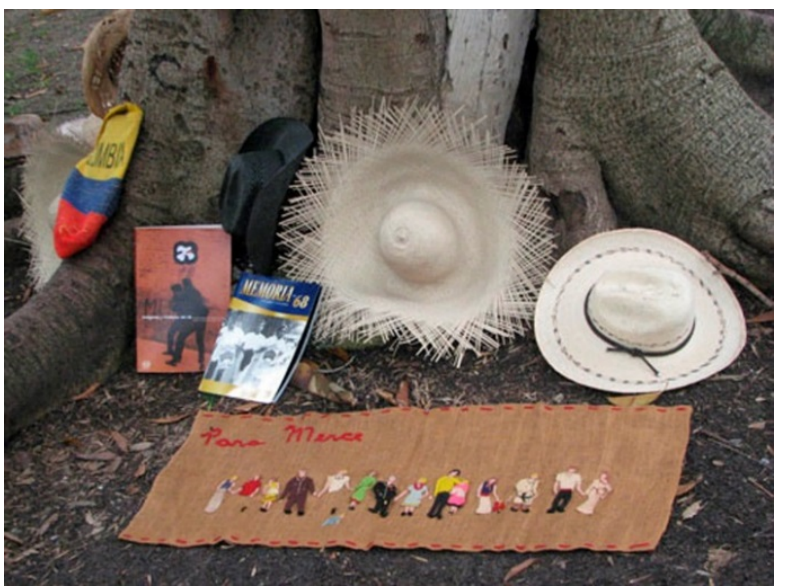

Imagen 4. Objetos de exiliados en la intervención Árbol del desexilio en la plaza de los Dos Congresos, CABA, 2006. 


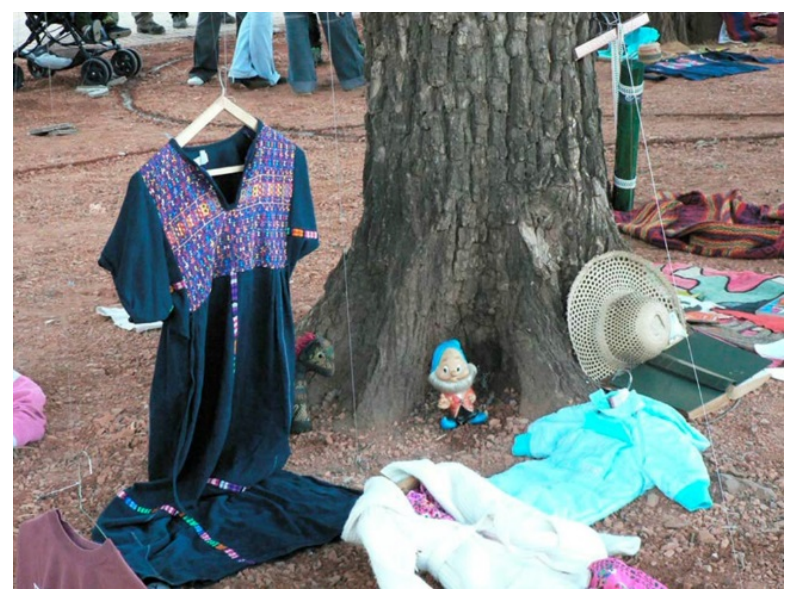

Imagen 5. Objetos de exiliados en la intervención Árbol del desexilio en la plaza de los Dos Congresos, CABA, 2006.

7Historias (2010) de Mercedes Fidanza

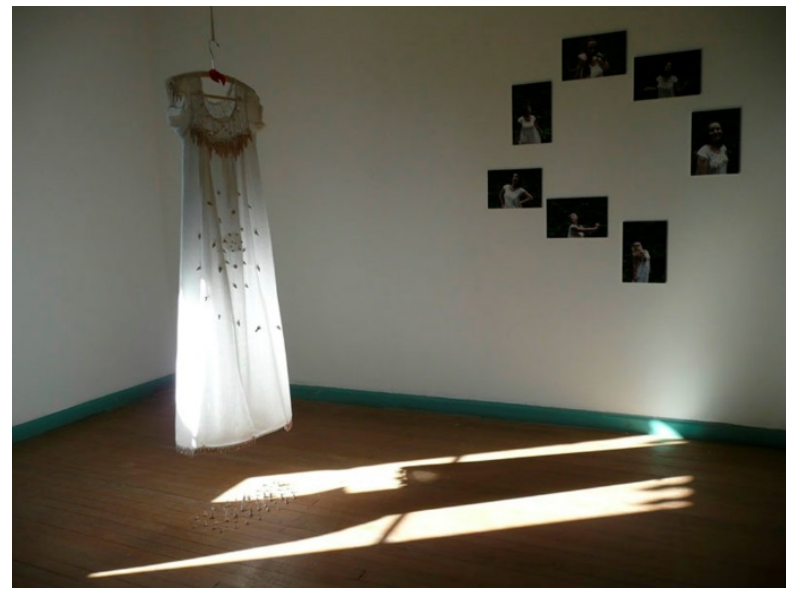

Imagen 6. Mercedes Fidanza, 7Historias, Julio 2010, Centro Cultural Chacra de los remedios, Casona de los Olivera, Buenos Aires, Argentina. C.A.B.A.

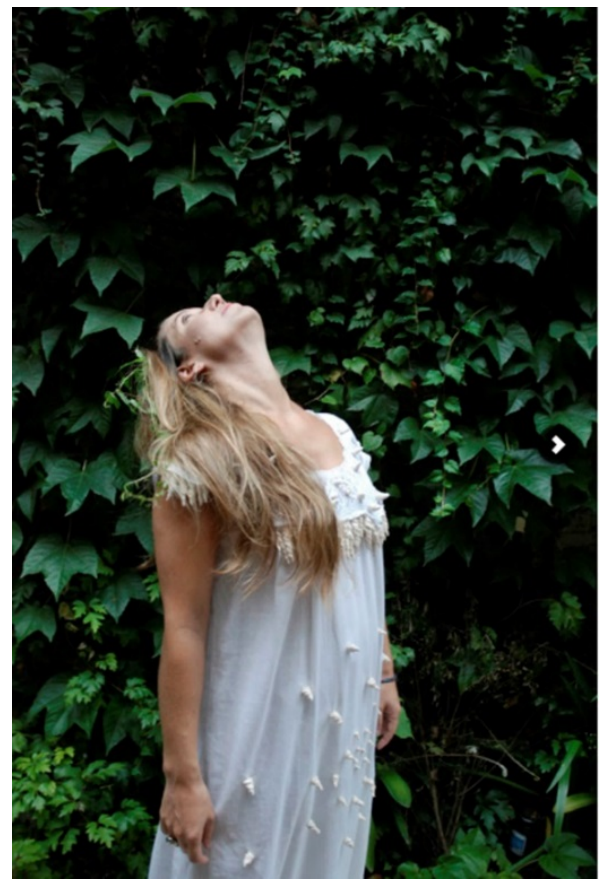

Imagen 7. Fotografía expuesta en 7Historias, Centro Cultural Chacra de los remedios, Casona de los Olivera, C.A.B.A, 2010. 


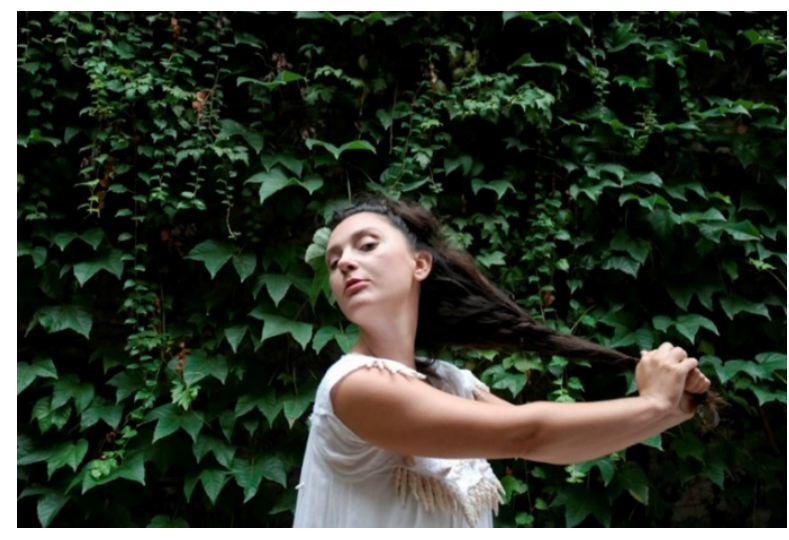

Imagen 8. Fotografía expuesta en 7Historias, Centro Cultural Chacra de los remedios, Casona de los Olivera, C.A.B.A, 2010.

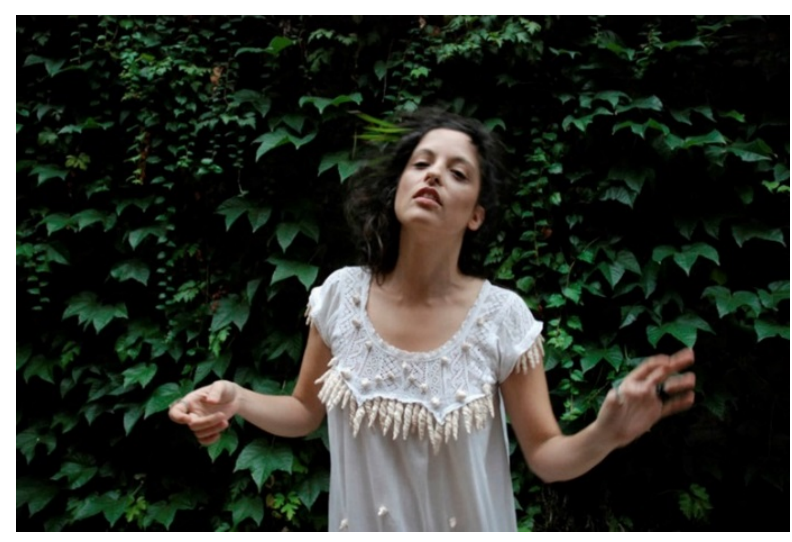

Imagen 9. Fotografía expuesta en 7Historias, Centro Cultural Chacra de los remedios, Casona de los Olivera, C.A.B.A, 2010.

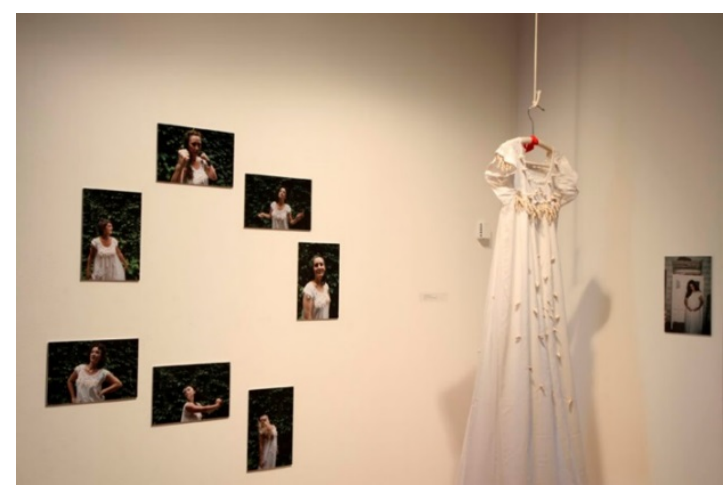

Imagen 10. Instalación 7Historias de Mercedes Fidanza Centro Cultural Chacra de los remedios, Casona de los Olivera, C.A.B.A, 2010.

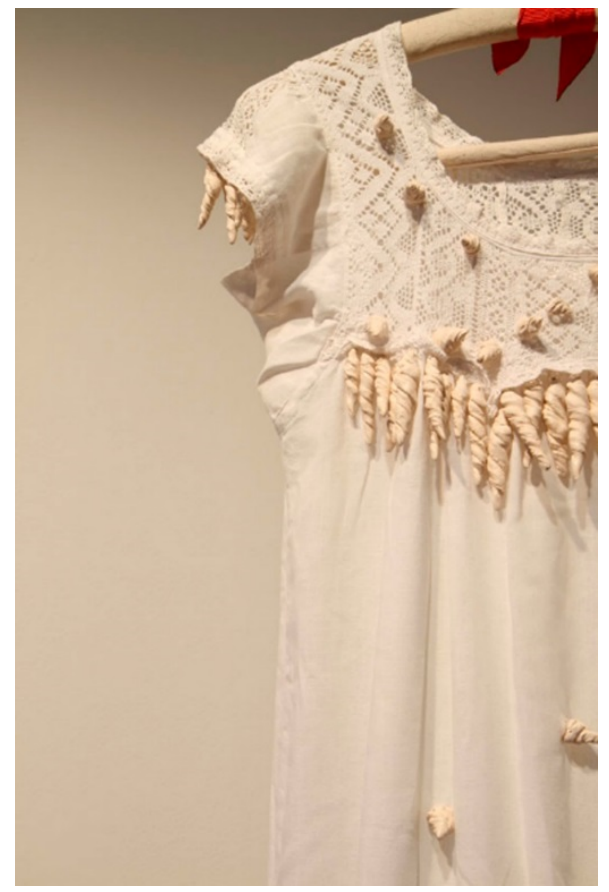

Imagen 11. Detalle del camisón intervenido con piezas cerámicas, expuesto en 7 Historias, Centro Cultural Chacra de los remedios, Casona de los Olivera, C.A.B.A, 2010.

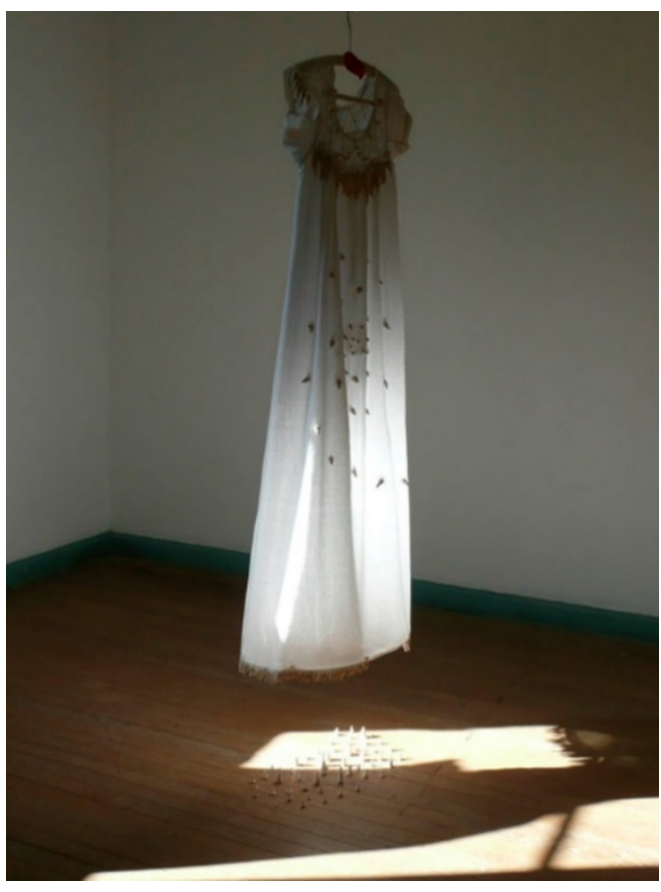

Imagen 12. Camisón intervenido con piezas cerámicas, expuesto en 7Historias, Centro Cultural Chacra de los remedios, Casona de los Olivera, C.A.B.A, 2010. 


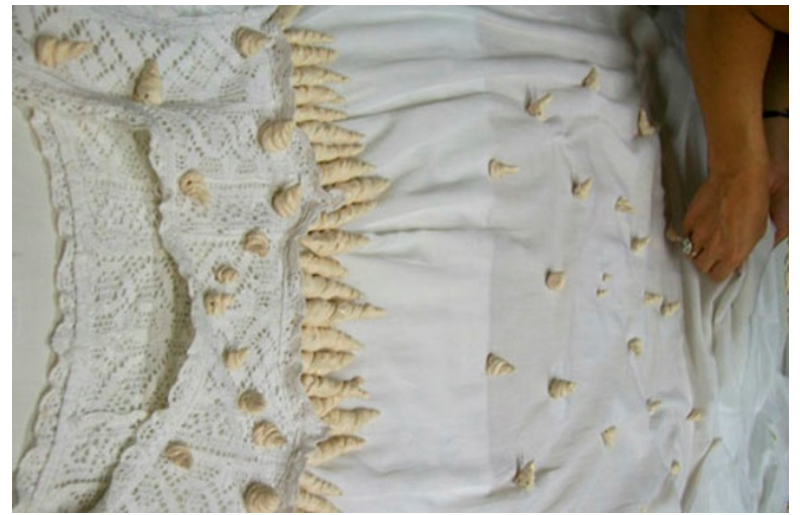

Imagen 13. Detalle del camisón intervenido con piezas cerámicas, expuesto en 7 Historias, Centro Cultural Chacra de los remedios, Casona de los Olivera, C.A.B.A, 2010. 


\section{Un niño de 30 años (2006) de Tomás Alzogaray Vanella}
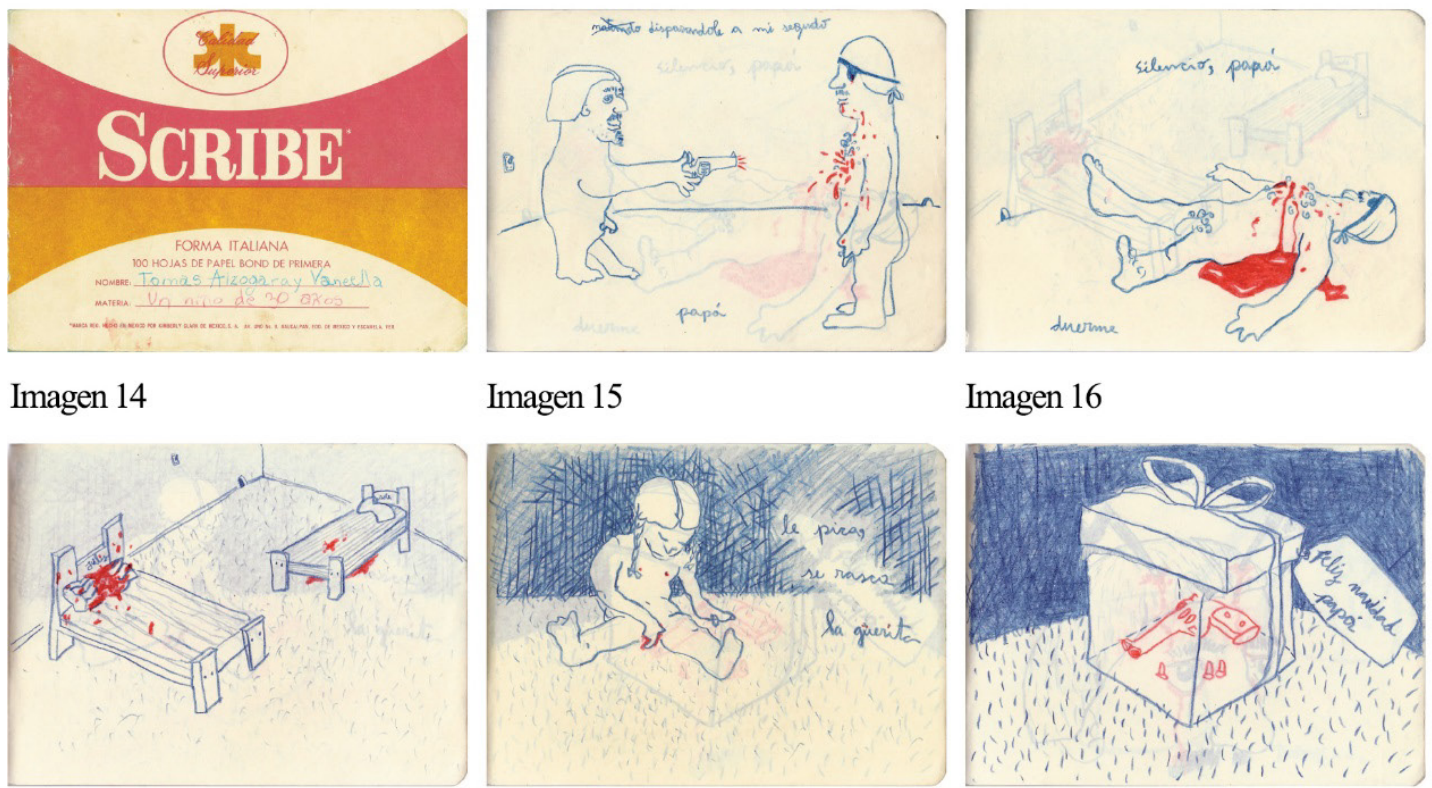

Imagen 16

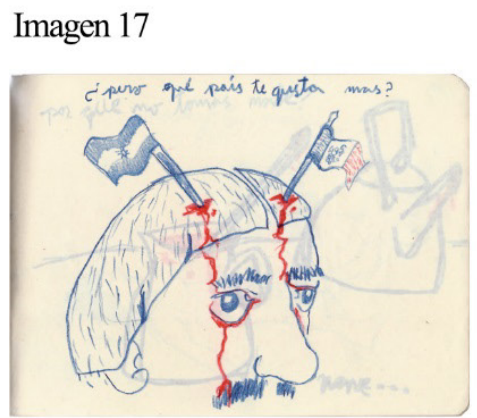

Imagen 18
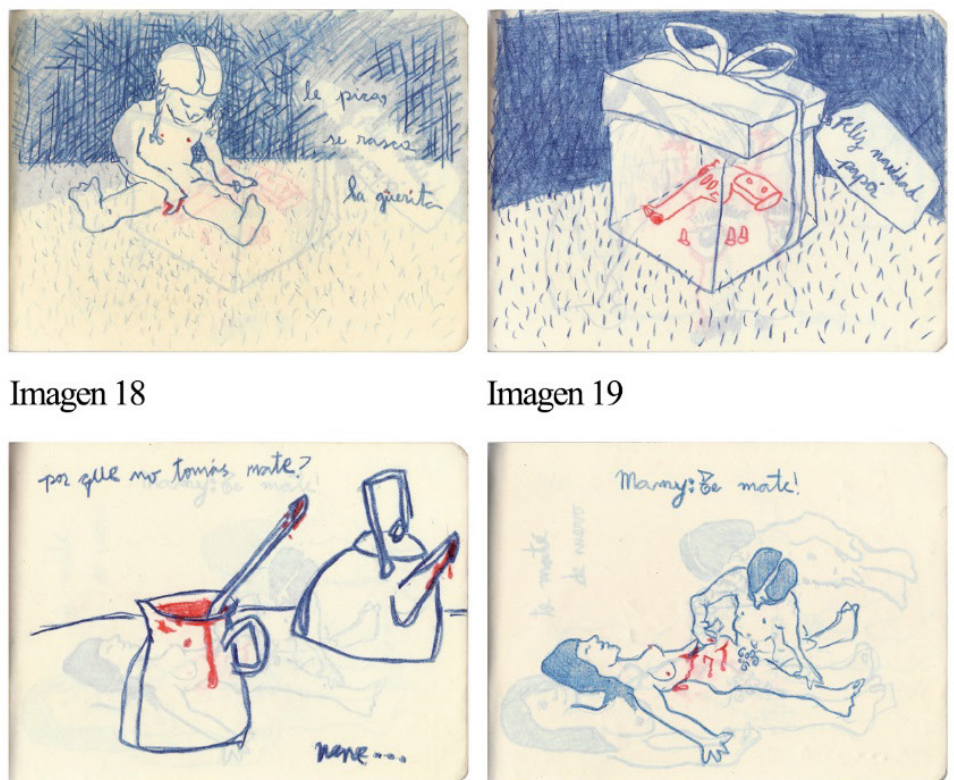

Imagen 19

Imagen 20

Imagen 21
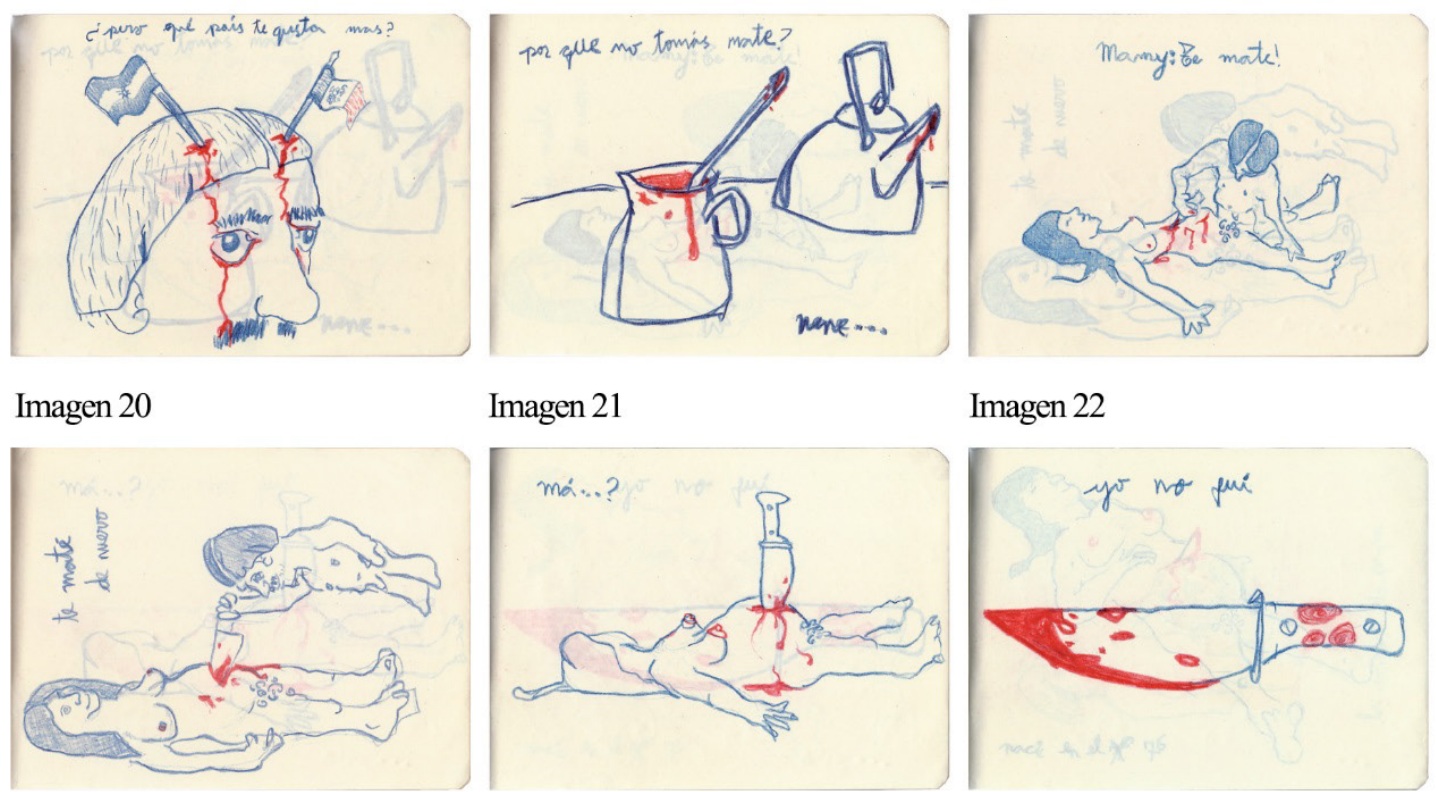

Imagen 22

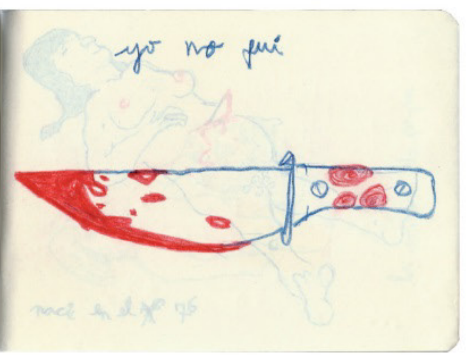

Imagen 23

Imagen 24

Imagen 25
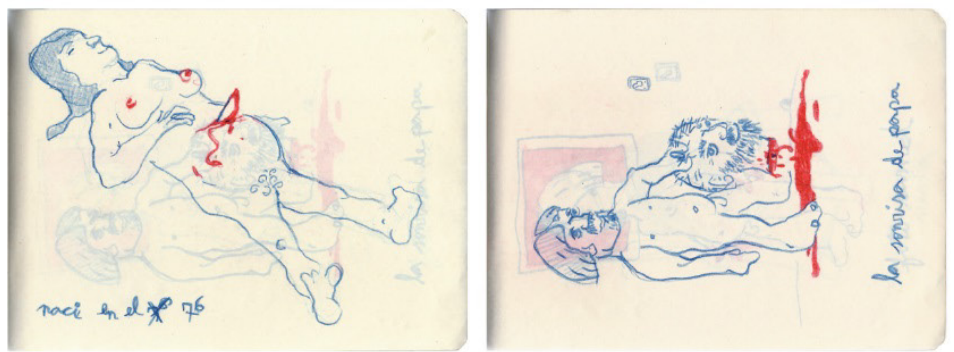

Imagen 26

Imagen 27

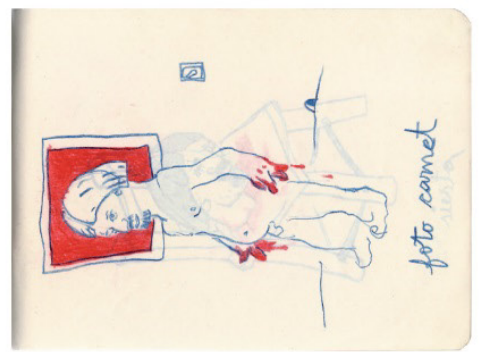

Imagen 28 


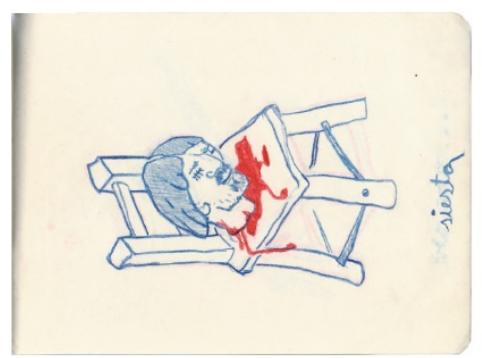

Imagen 29

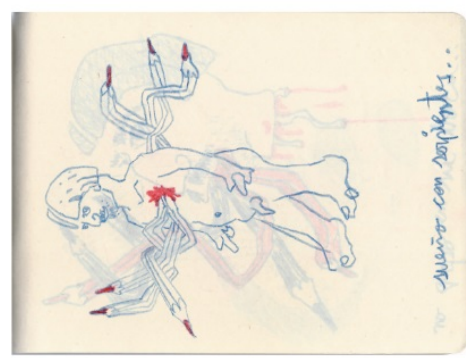

Imagen 32

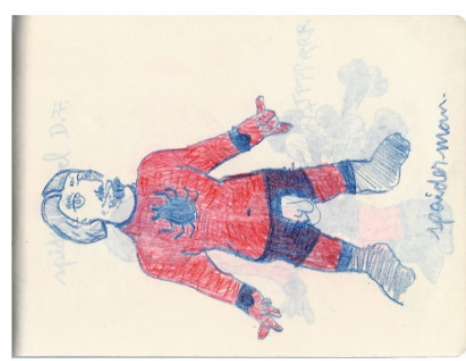

Imagen 35

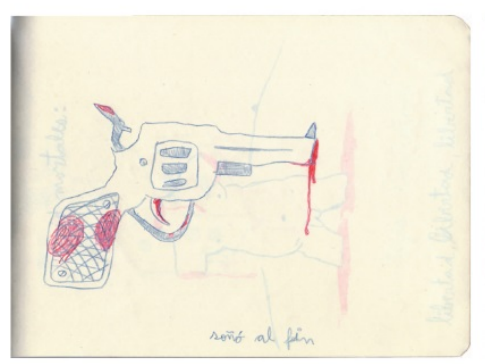

Imagen 38

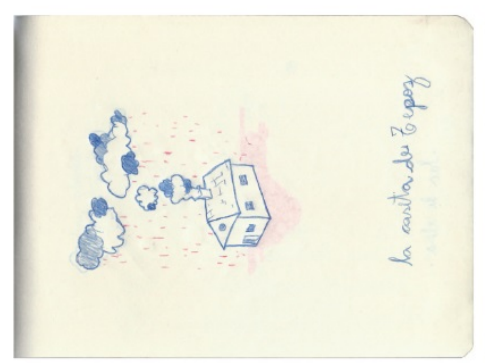

Imagen 41

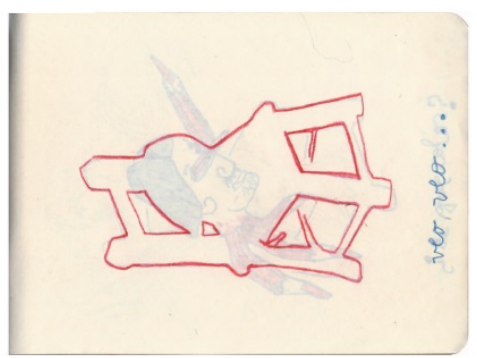

Imagen 30

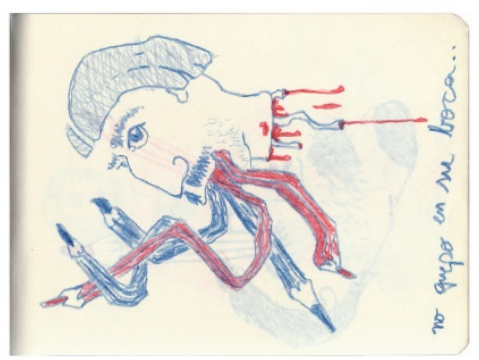

Imagen 33

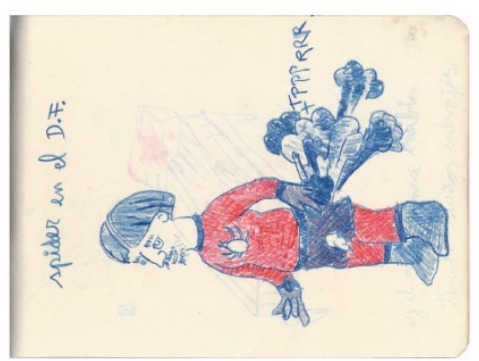

Imagen 36

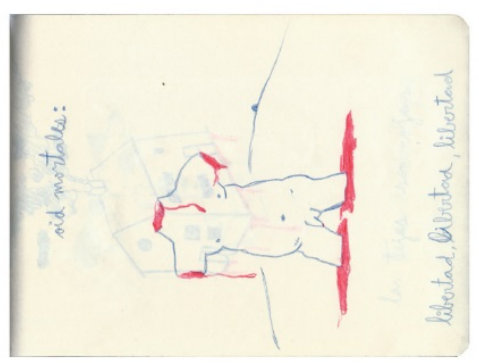

Imagen 39

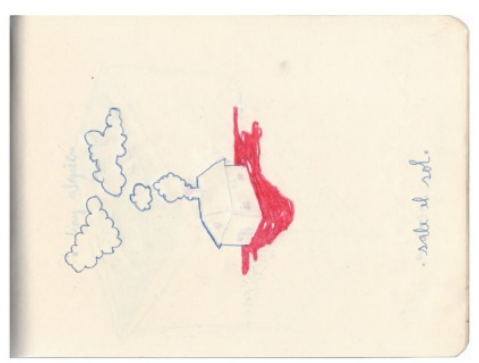

Imagen 42

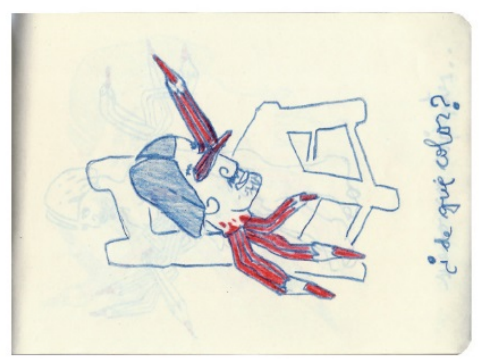

Imagen 31

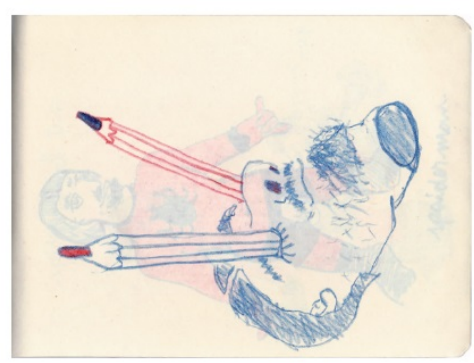

Imagen 34

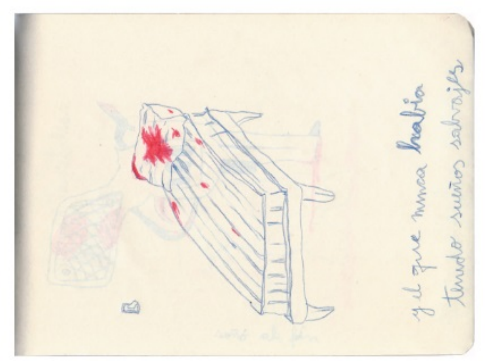

Imagen 37

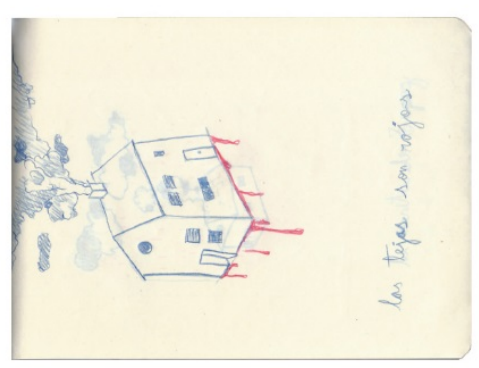

Imagen 40

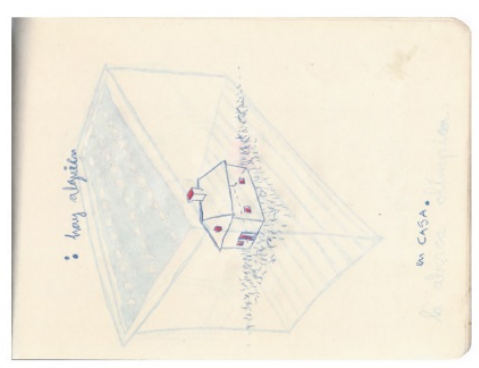

Imagen 43 


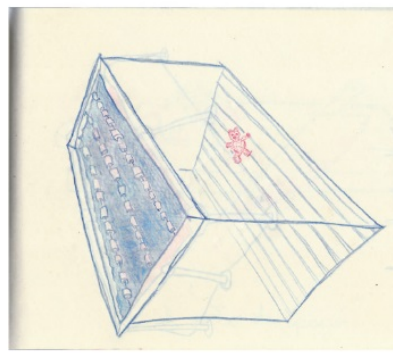

Imagen 44

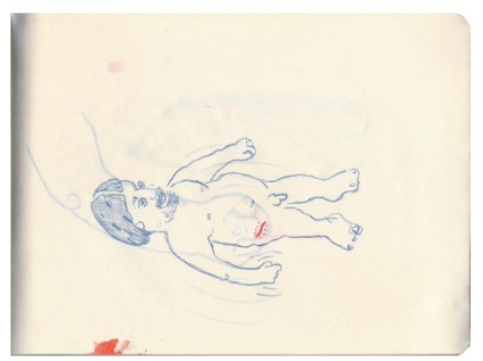

Imagen 47

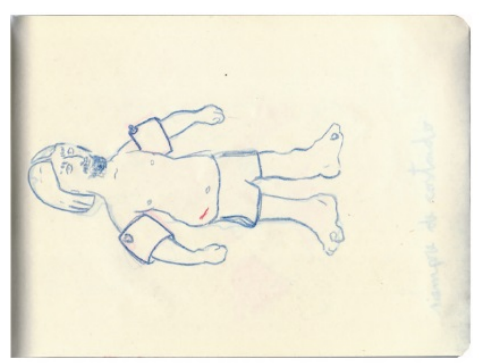

Imagen 50

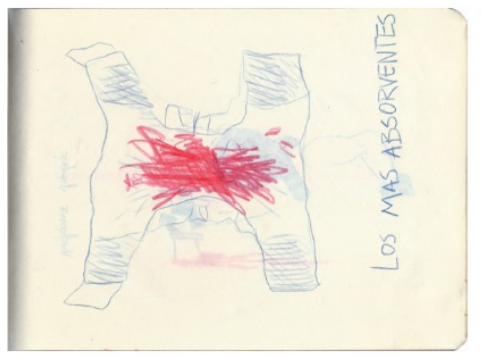

Imagen 53

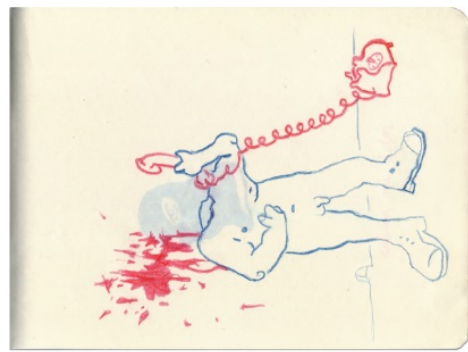

Imagen 56

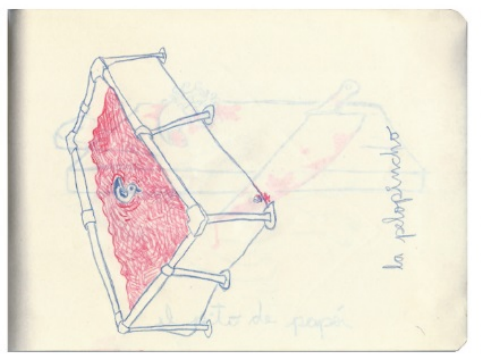

Imagen 45

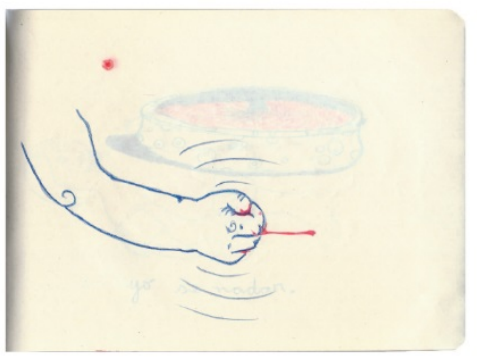

Imagen 48

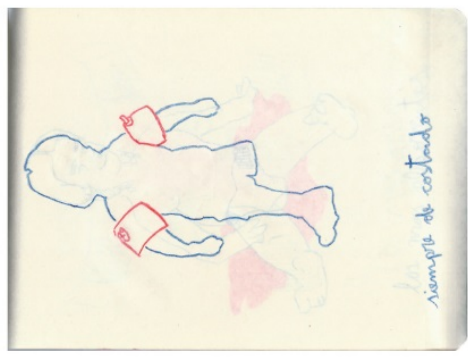

Imagen 51

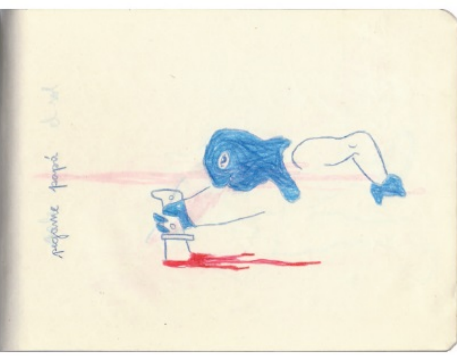

Imagen 54

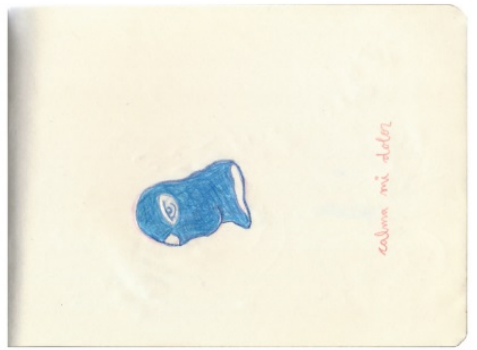

Imagen 57

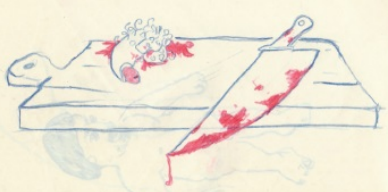

el pito de papá

Imagen 46

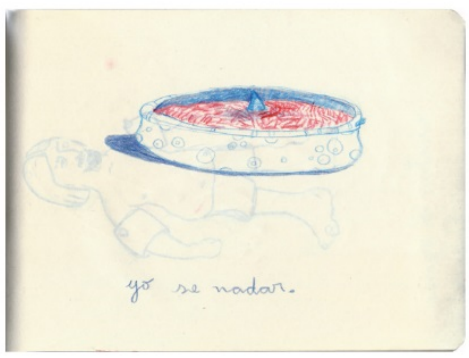

Imagen 49

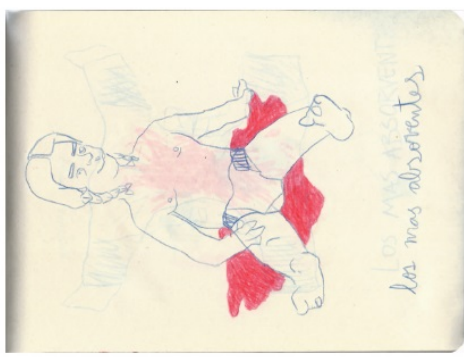

Imagen 52

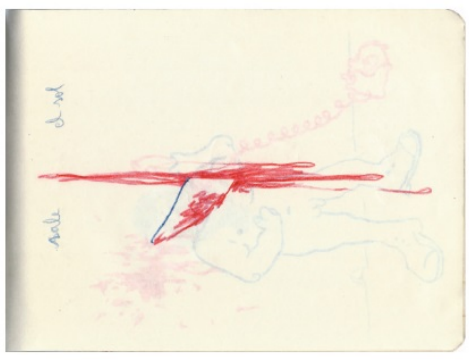

Imagen 55

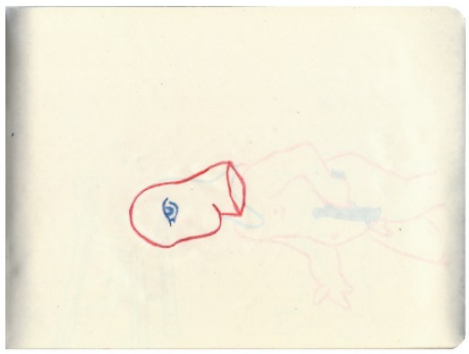

Imagen 58

174 


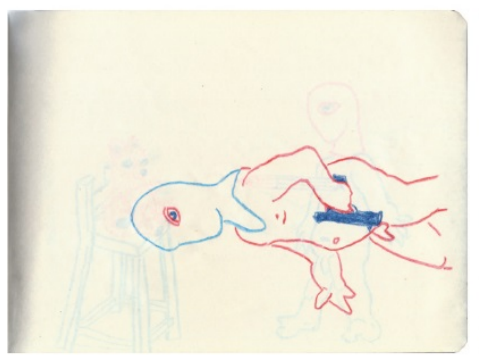

Imagen 59

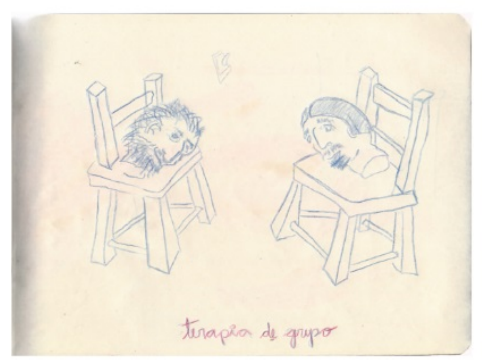

Imagen 62

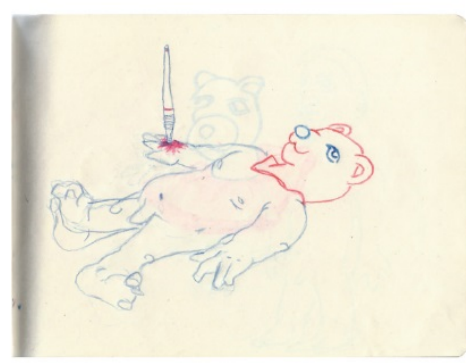

Imagen 65

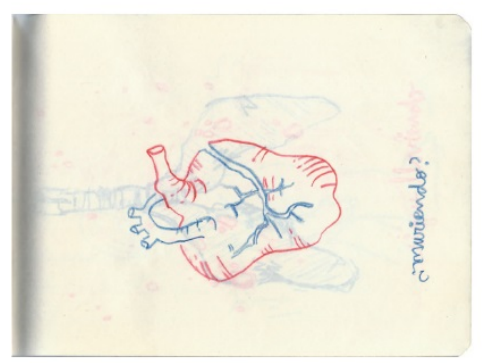

Imagen 68

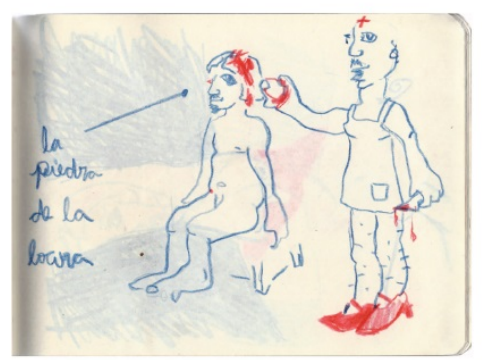

Imagen 71

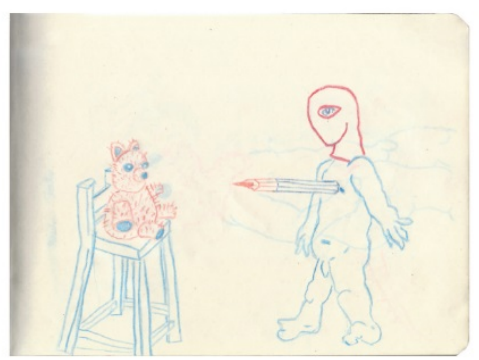

Imagen 60

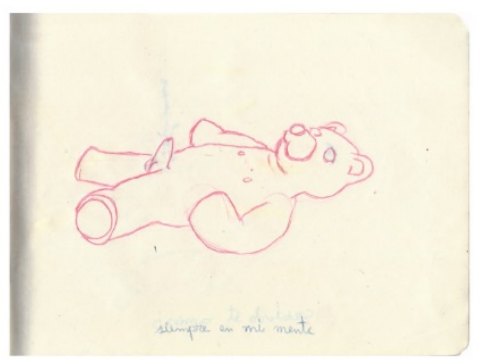

Imagen 63

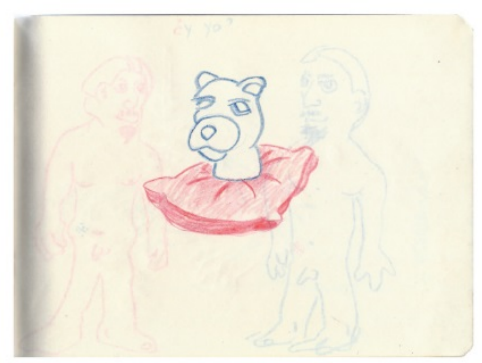

Imagen 66

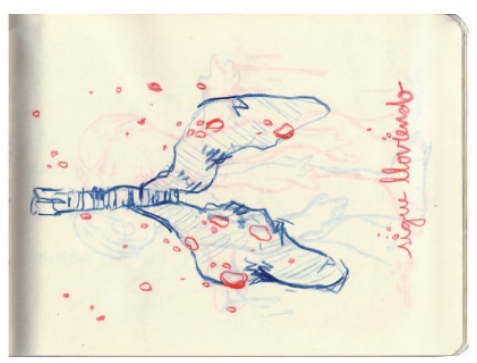

Imagen 69

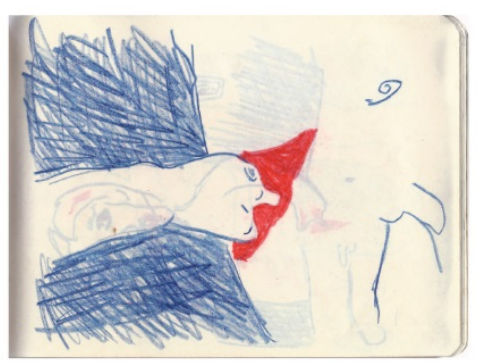

Imagen 72

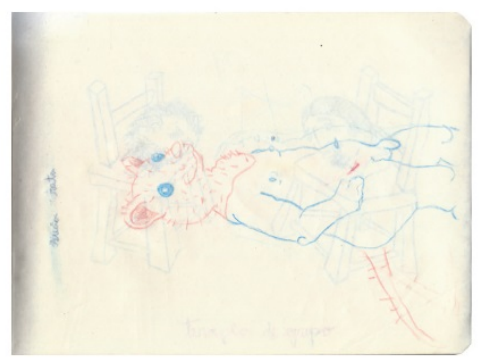

Imagen 61

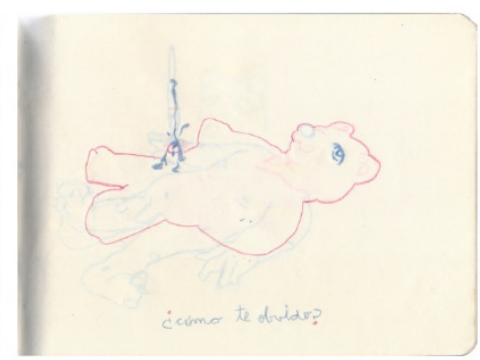

Imagen 64

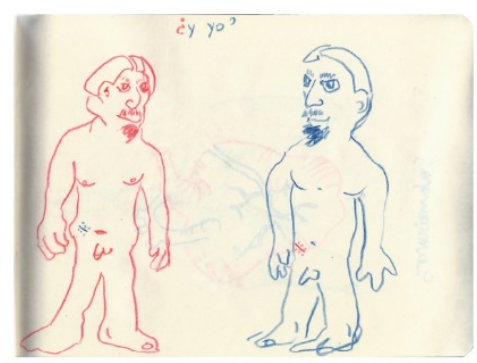

Imagen 67

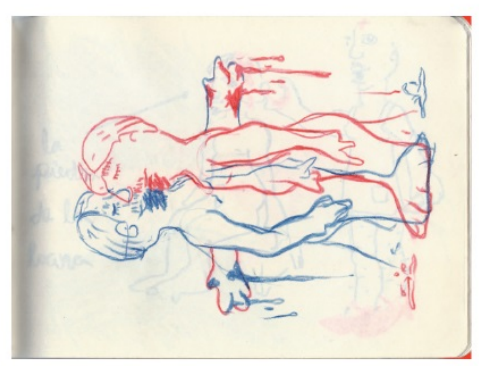

Imagen 70

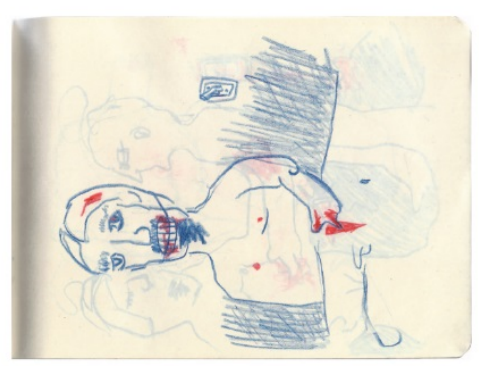

Imagen 73 


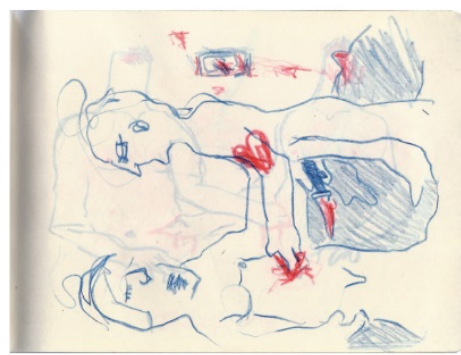

Imagen 74

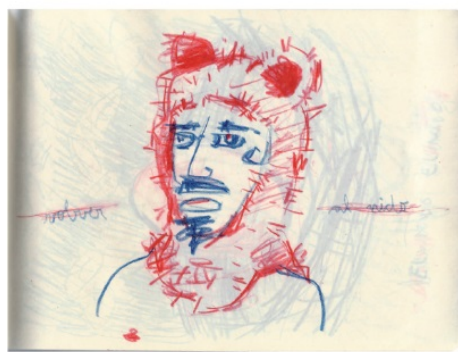

Imagen 77

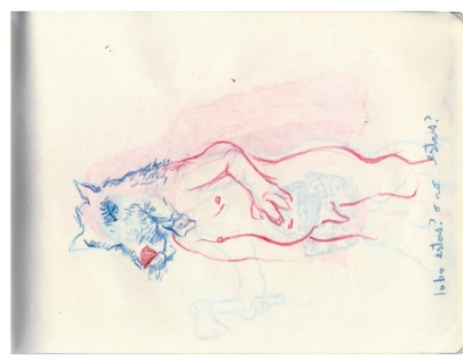

Imagen 80

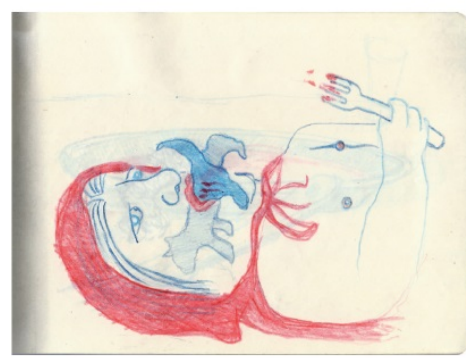

Imagen 83

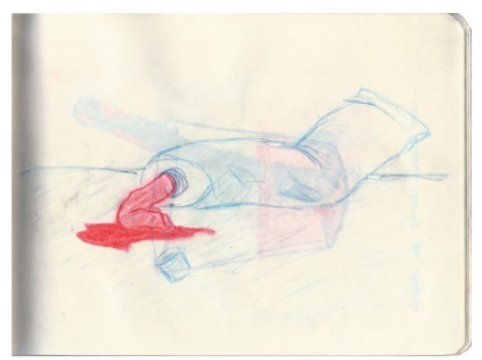

Imagen 86

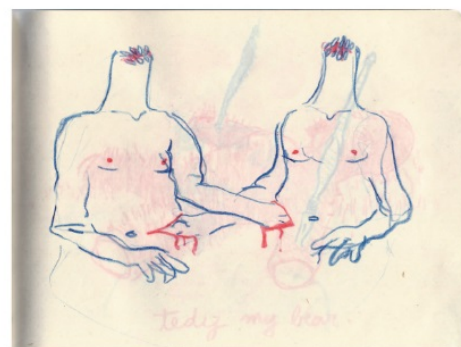

Imagen 75

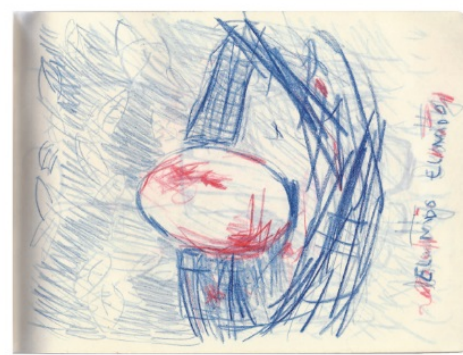

Imagen 78

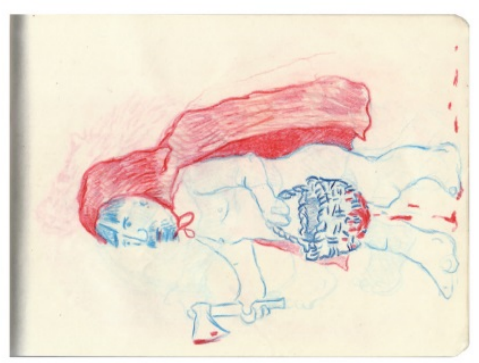

Imagen 81

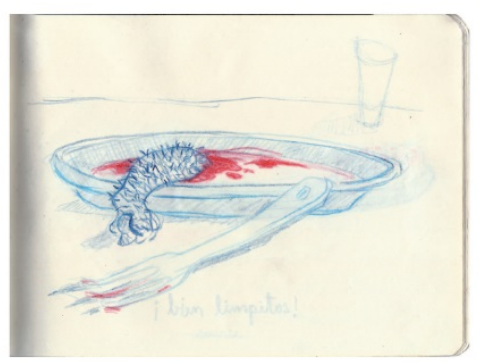

Imagen 84

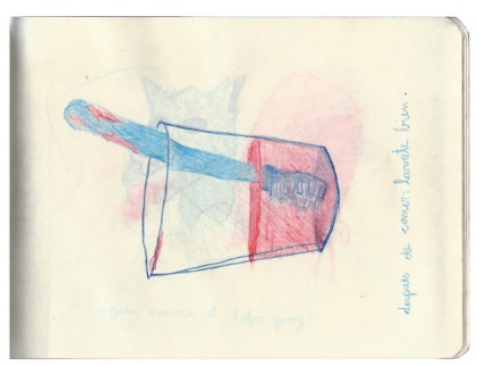

Imagen 87

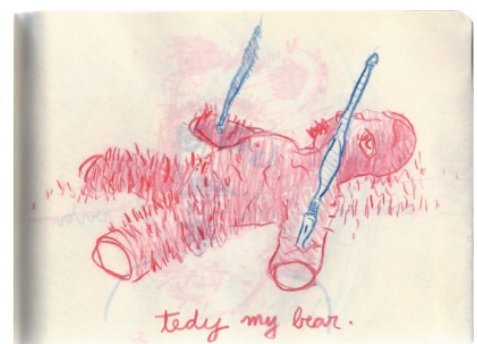

Imagen 76

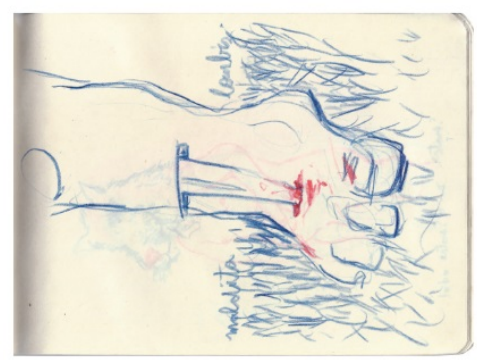

Imagen 79

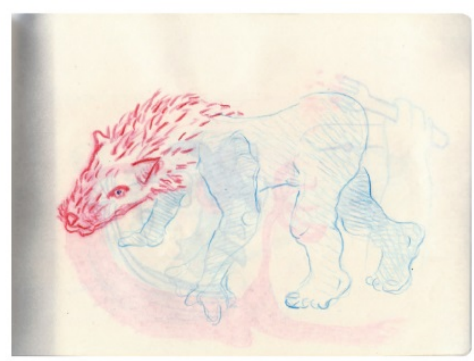

Imagen 82

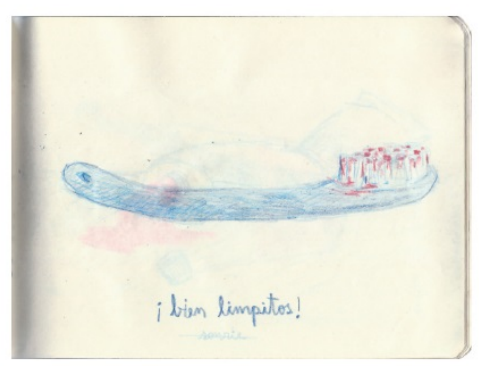

Imagen 85

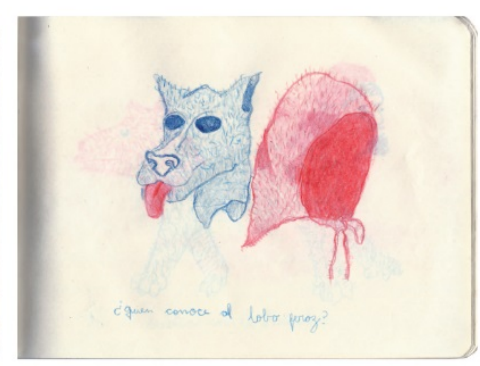

Imagen 88 


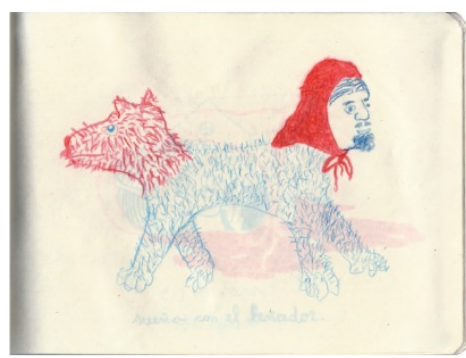

Imagen 89

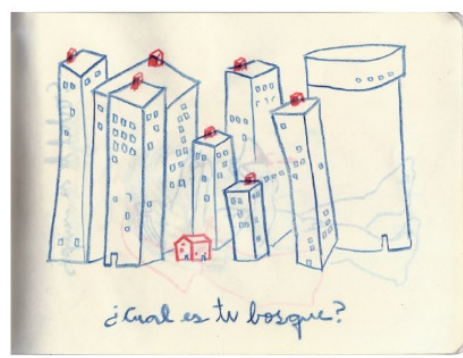

Imagen 92

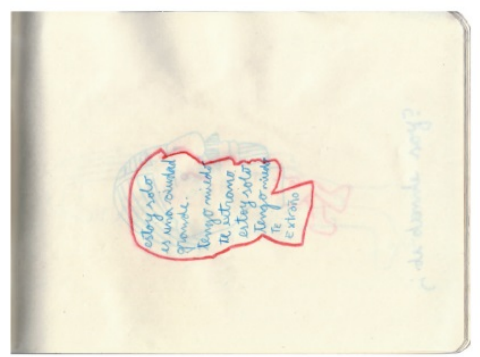

Imagen 95

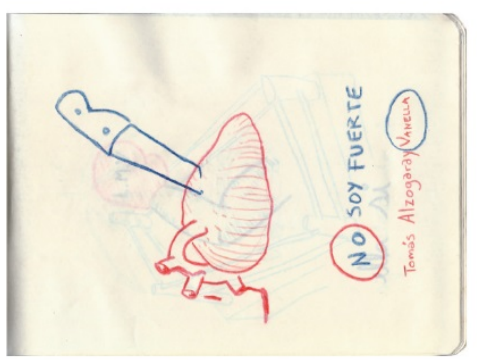

Imagen 98

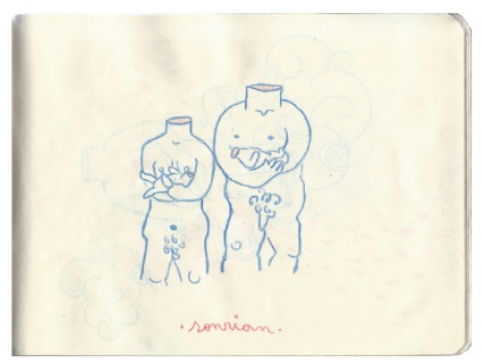

Imagen 101

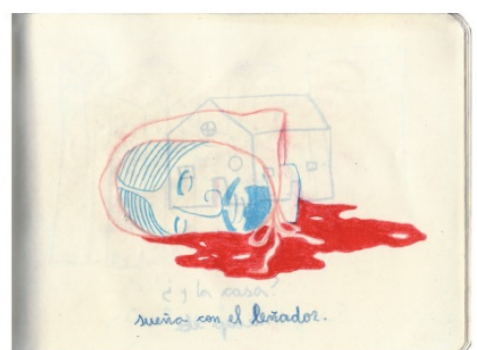

Imagen 90

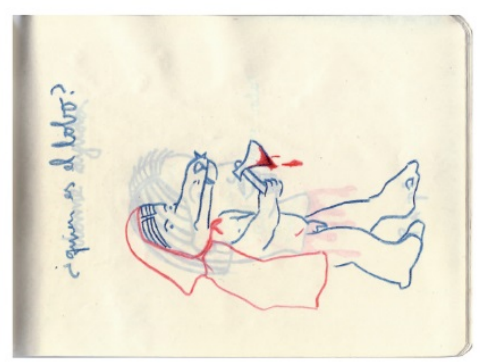

Imagen 93

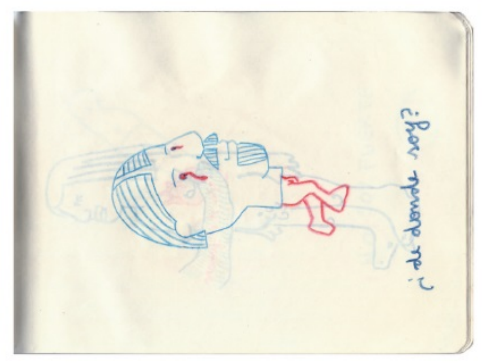

Imagen 96

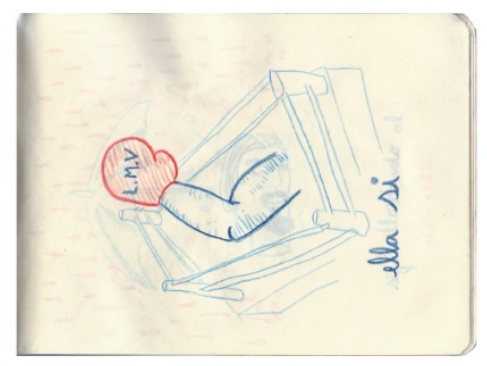

Imagen 99

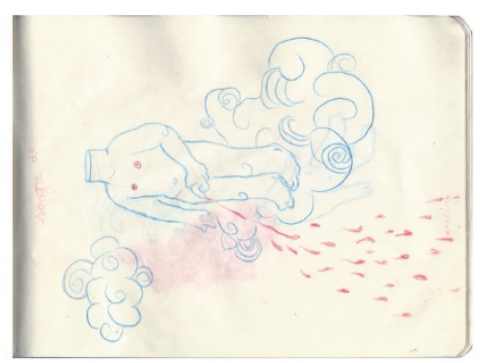

Imagen 102

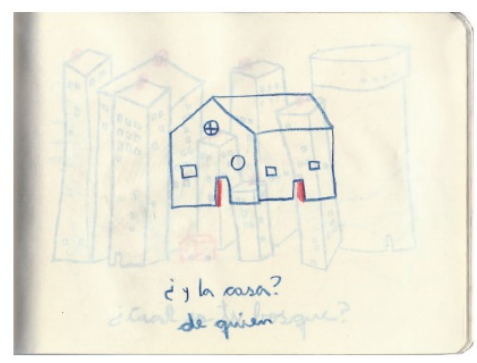

Imagen 91

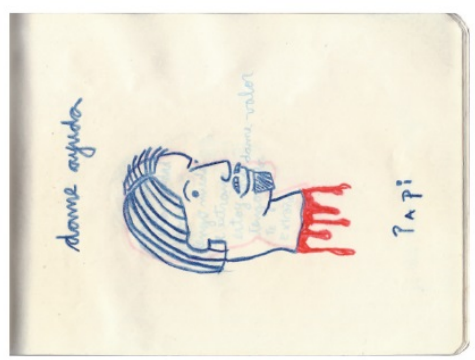

Imagen 94

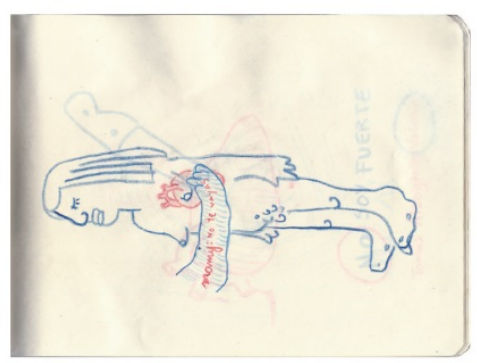

Imagen 97

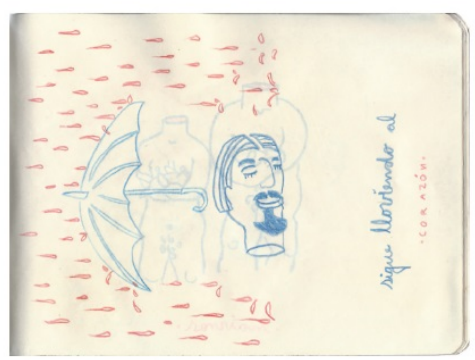

Imagen 100

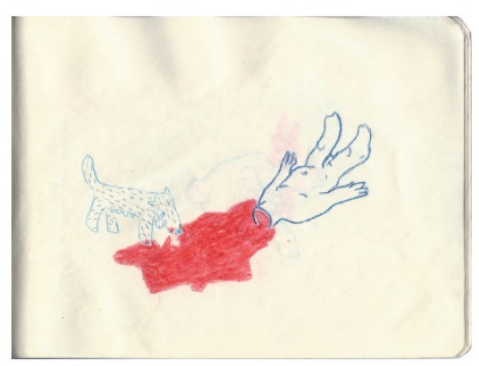

Imagen 103 


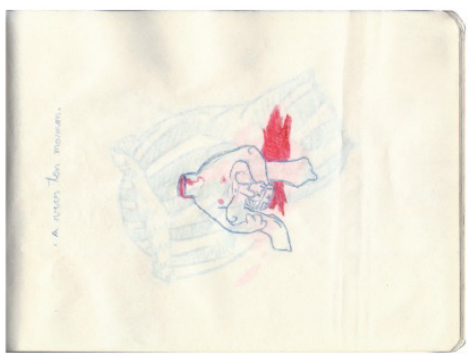

Imagen 104

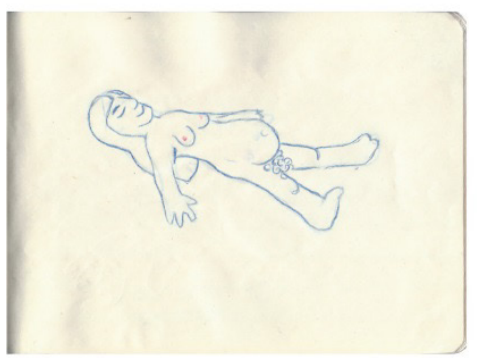

Imagen 107

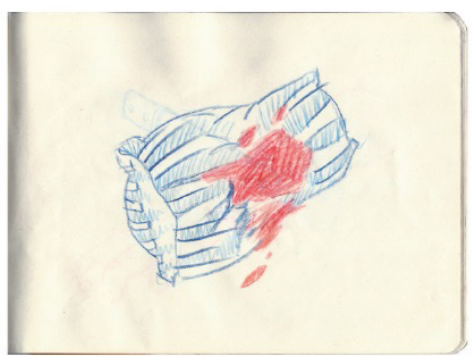

Imagen 105

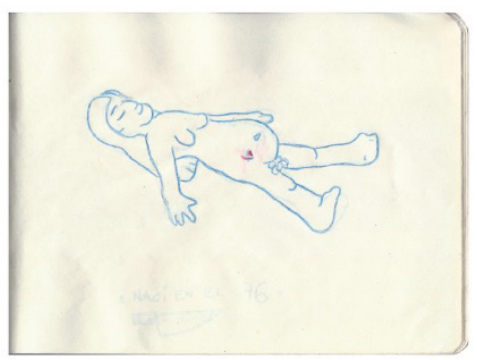

Imagen 108

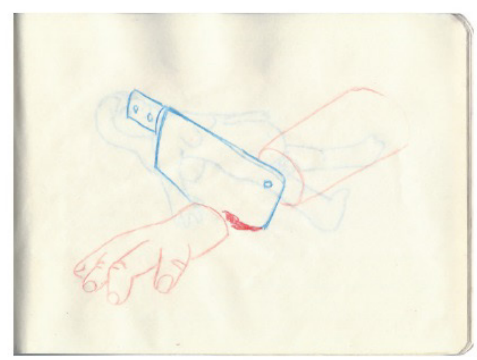

Imagen 106

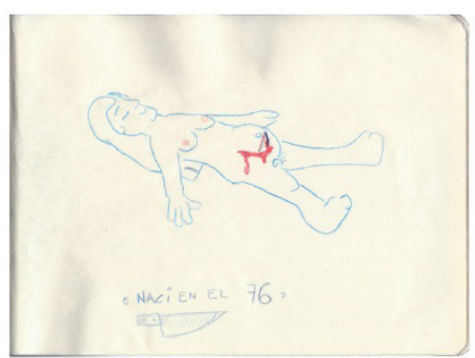

Imagen 109 


\section{El niño que odia (2007-2011) de Tomás Alzogaray Vanella}

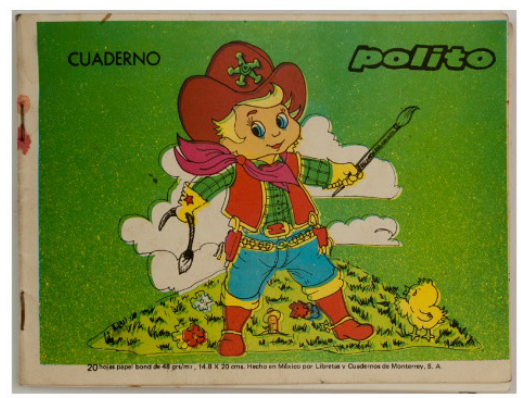

Imagen 110

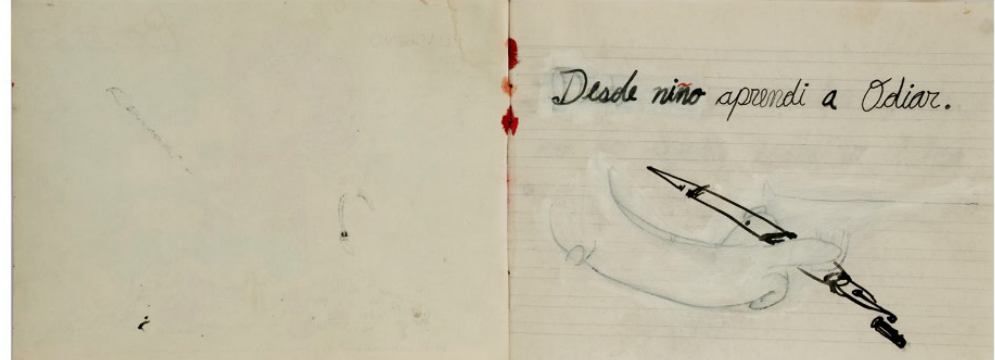

Imagen 111

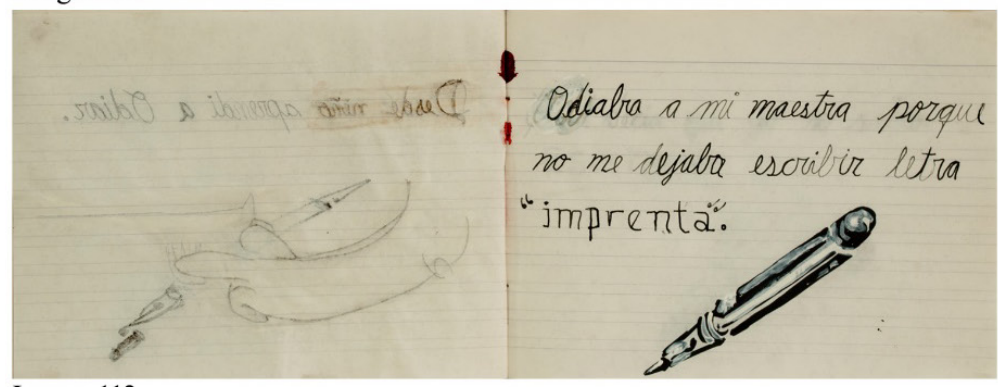

Imagen 112

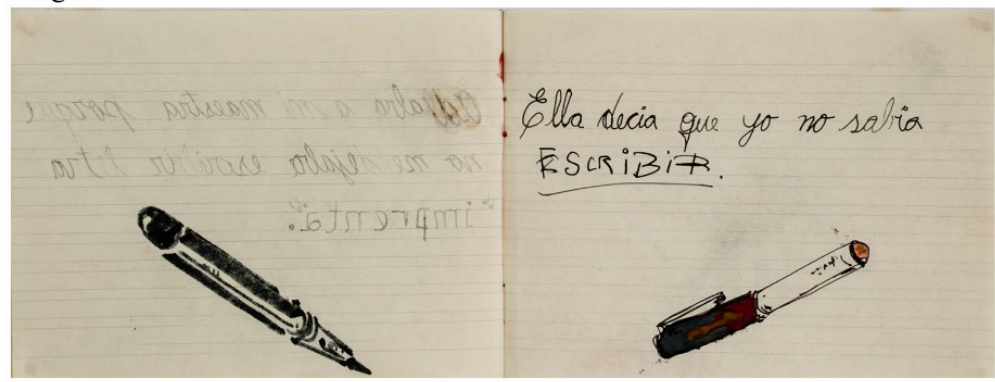

Imagen 113

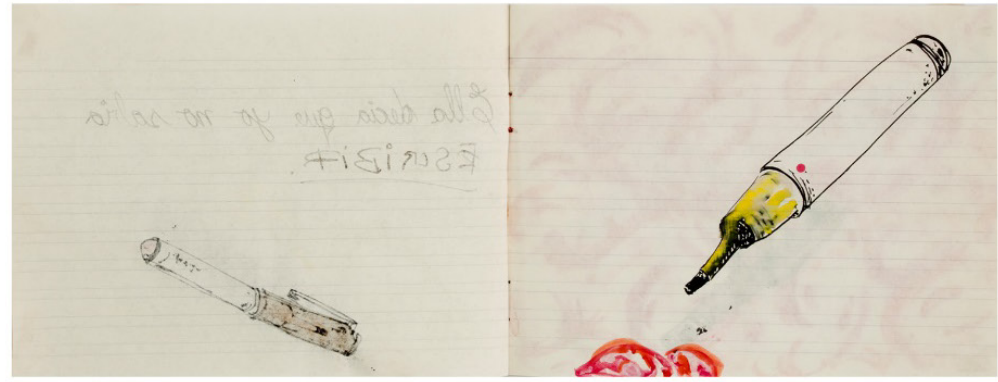

Imagen 114 


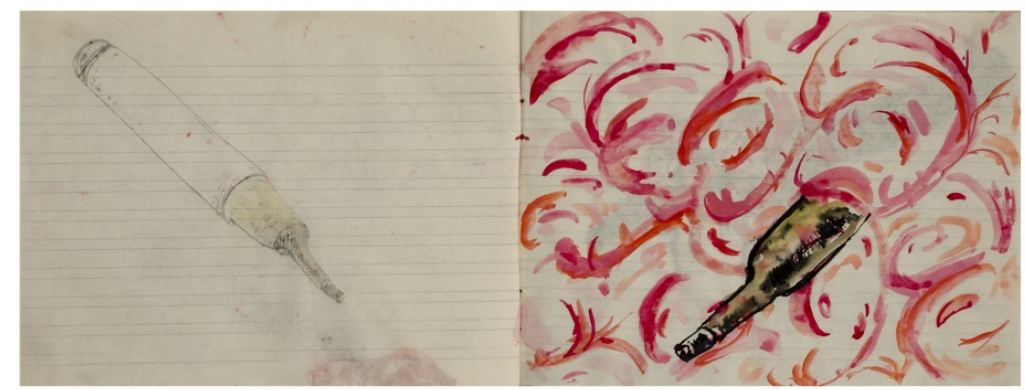

Imagen 115

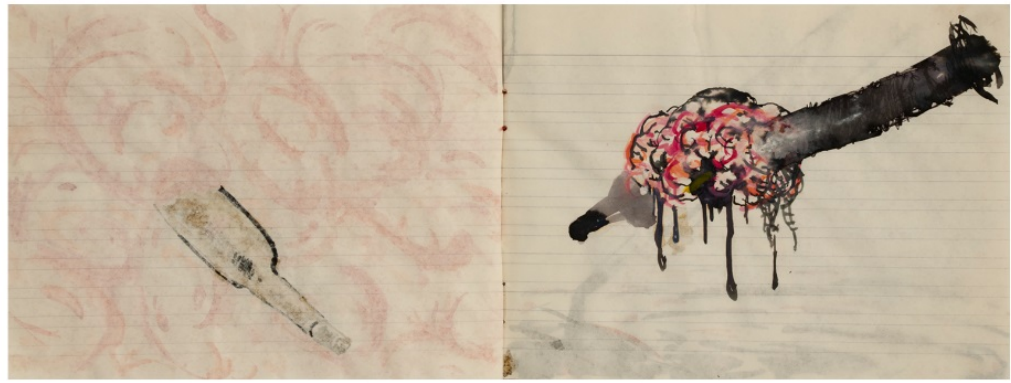

Imagen 116

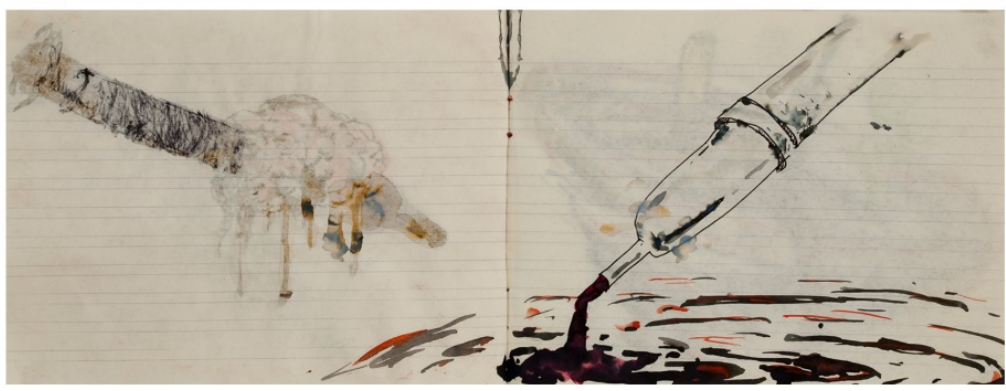

Imagen 117

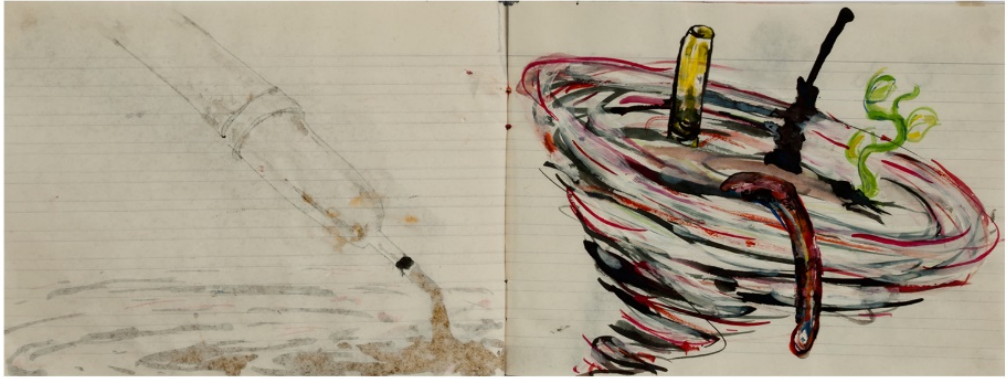

Imagen 118

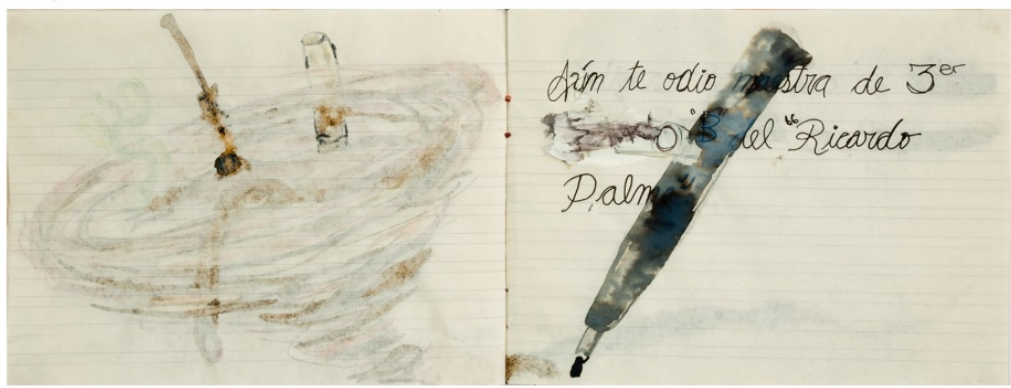

Imagen 119 


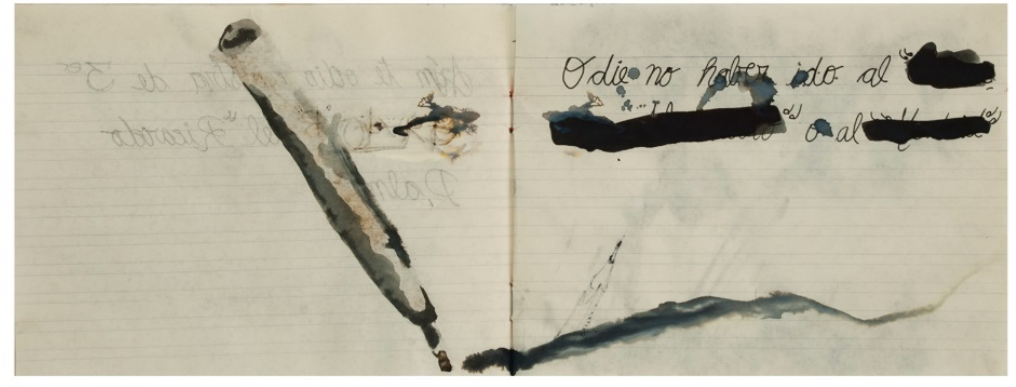

Imagen 120

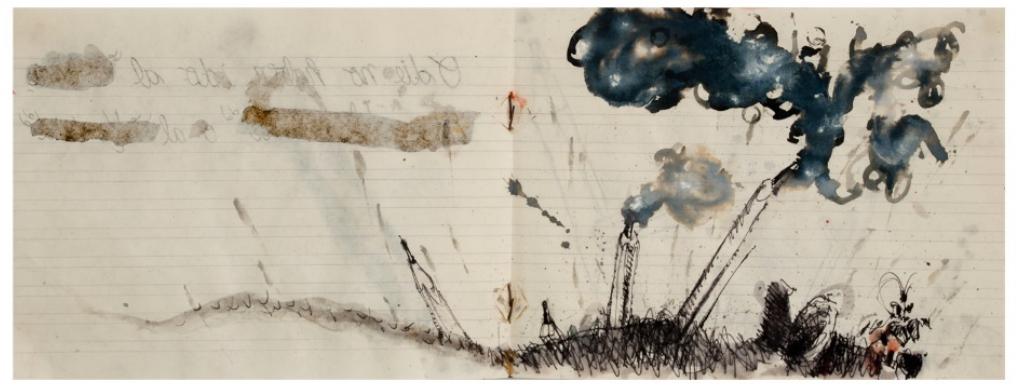

Imagen 121

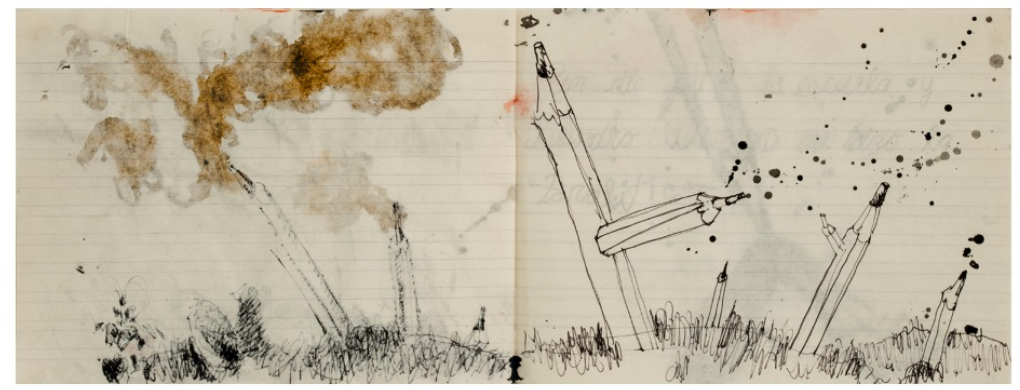

Imagen 122

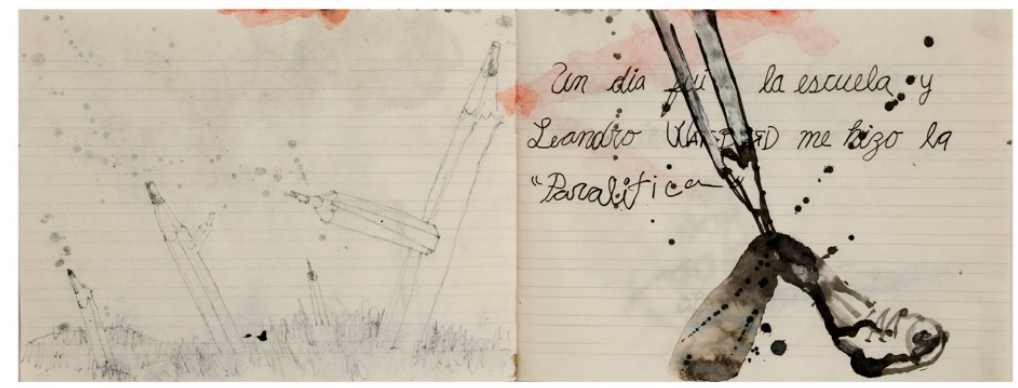

Imagen 123

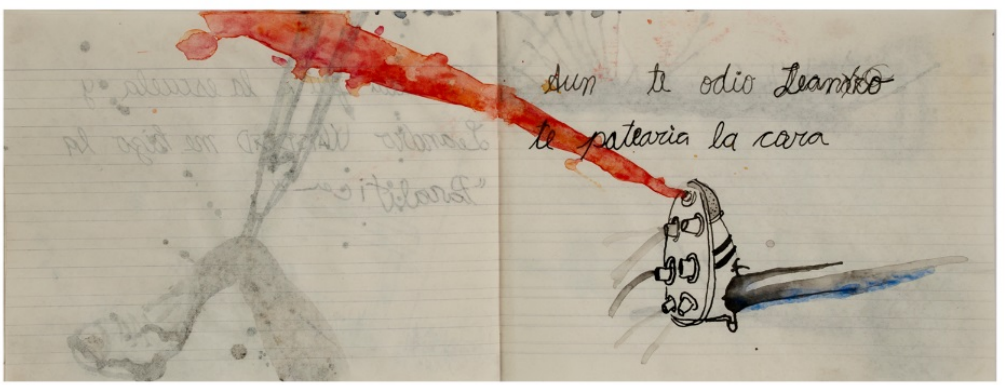

Imagen 124 


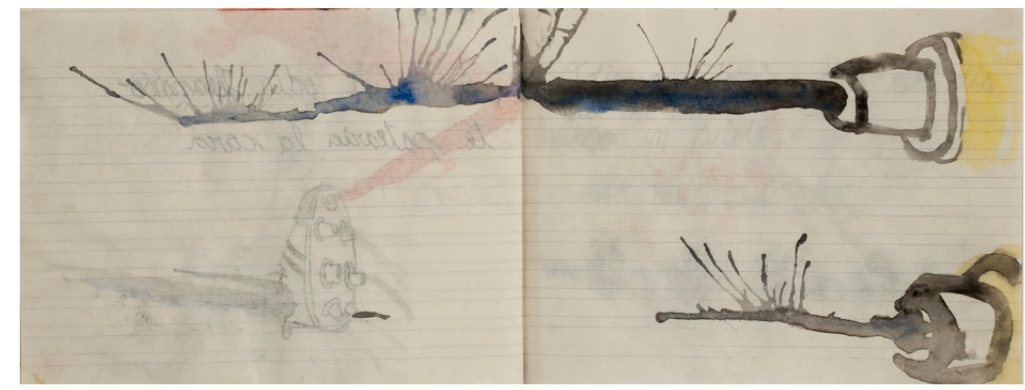

Imagen 125

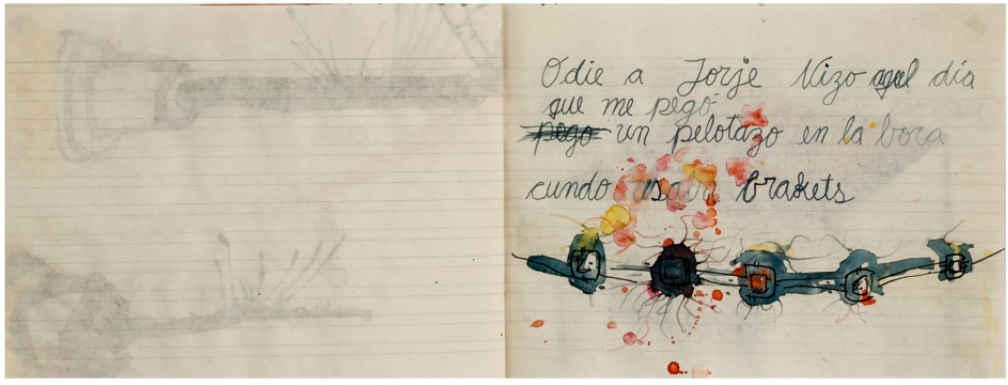

Imagen 126

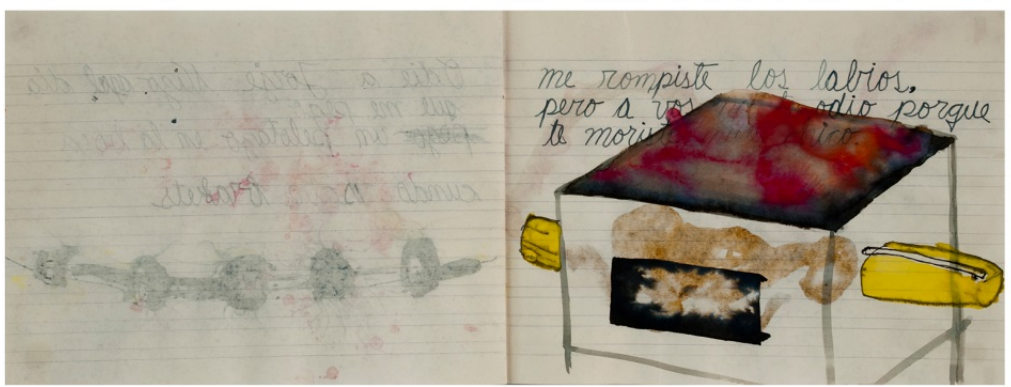

Imagen 127

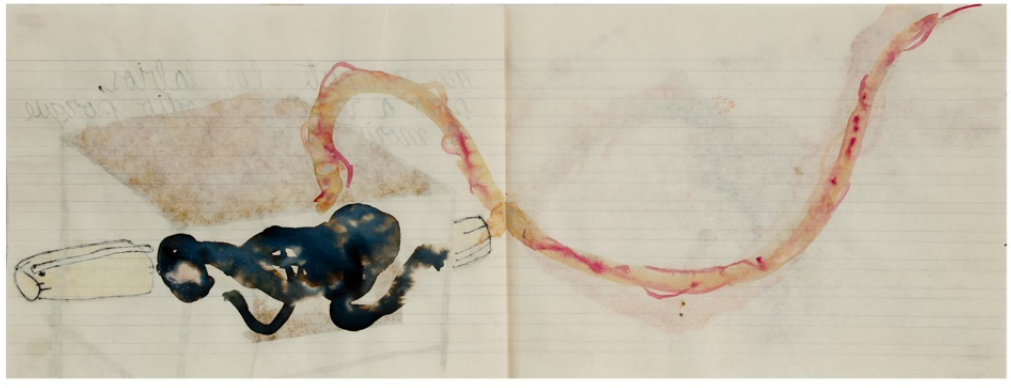

Imagen 128

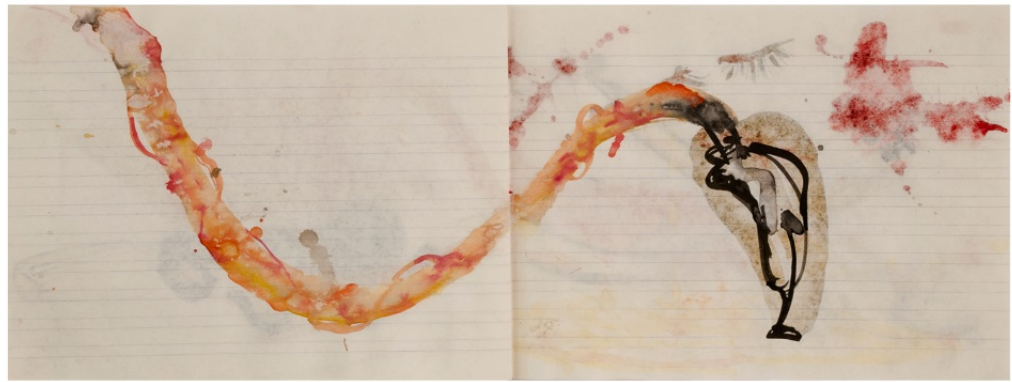

Imagen 129 


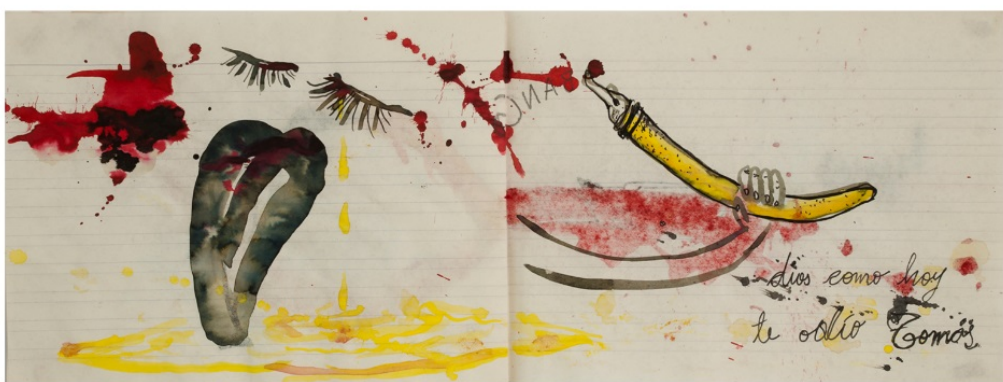

Imagen 130

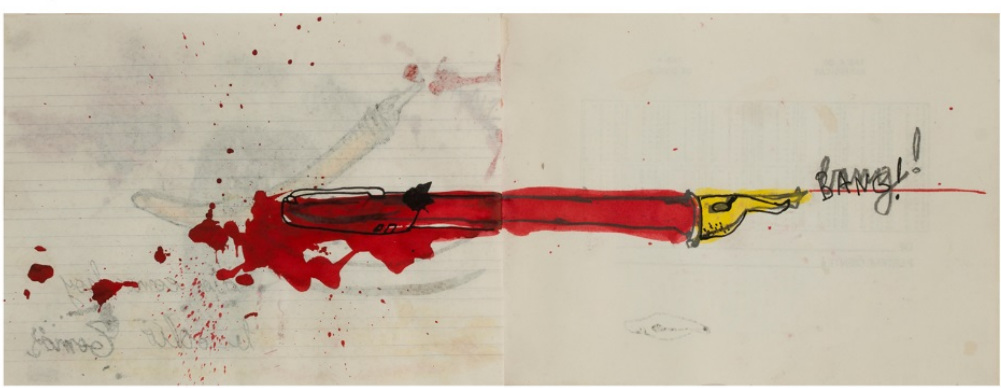

Imagen 131

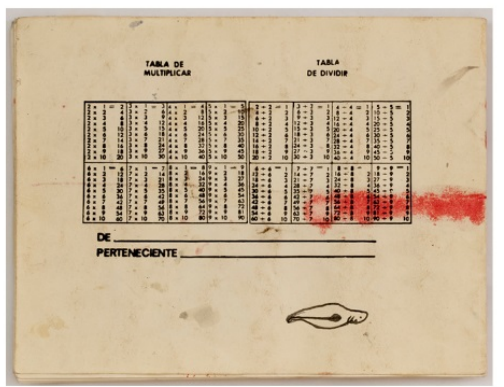

Imagen 132 


\section{El objeto del exilio (2013) de Liza Casullo y Federico Joselevich Puiggrós}

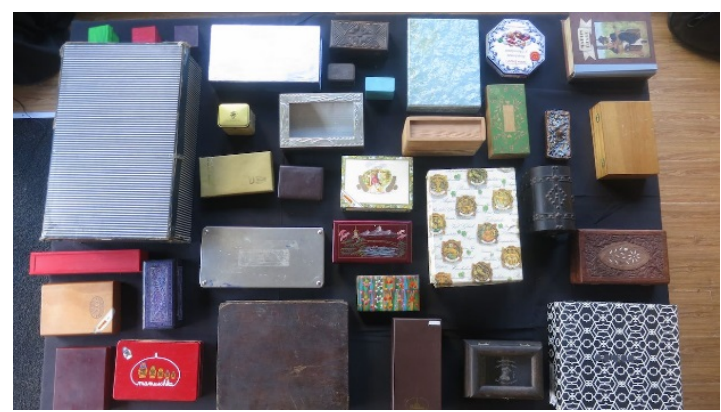

Imagen 133. Instalación de los objetos en sus respectivas cajas.

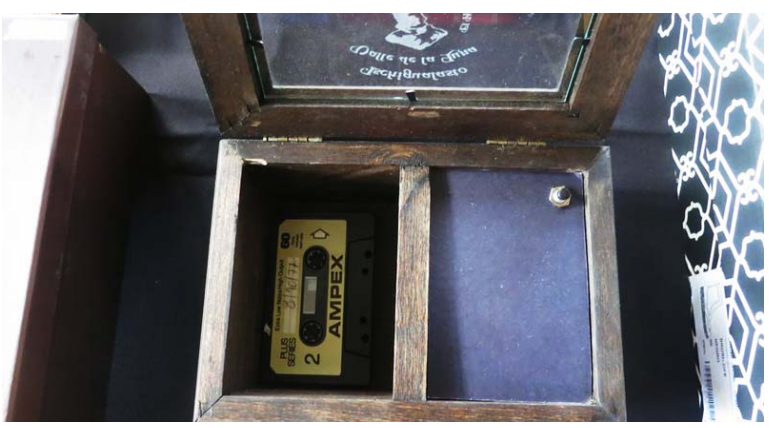

Imagen 134. "Cartas cassette de años 70s." (Extraído de la página web de Joselevich Puiggrós).

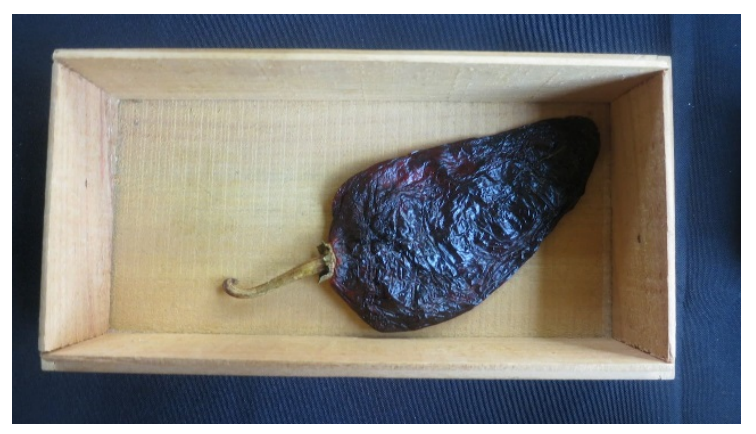

Imagen 135. Chile mexicano.

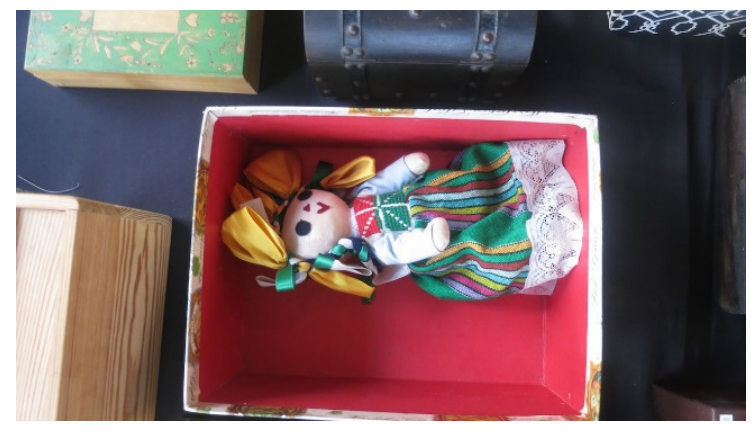

Imagen 136. Típica muñeca de trapo mexicana conocida como "Marías."

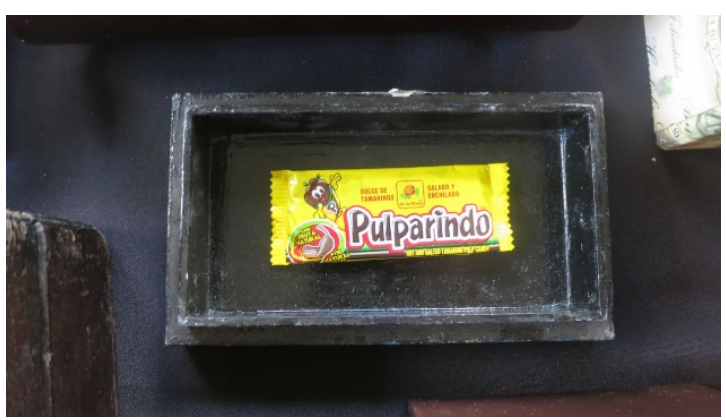

Imagen 137. "A los ocho años, a Mariana Casullo la regañó la maestra y le puso una nota en el cuaderno de comunicaciones: había convidado a sus compañeros una golosina con chile que le habían traído de México y todos terminaron 1lorando." (Extraído de la página web de Joselevich Puiggrós).

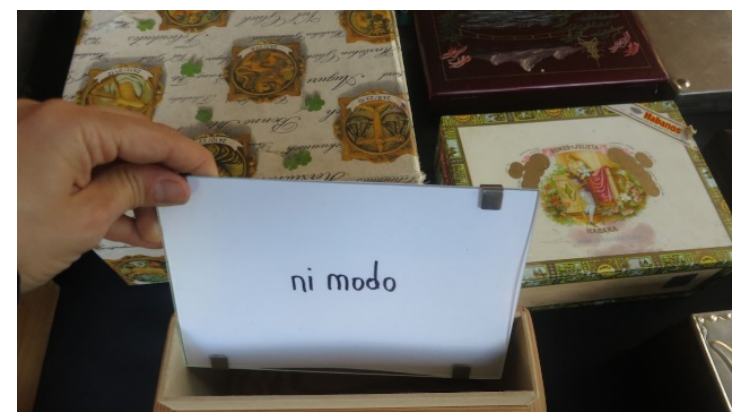

Imagen 138. "Frase recuperada por Maya Mercer". (Extraído de la página web de Joselevich Puiggrós). 


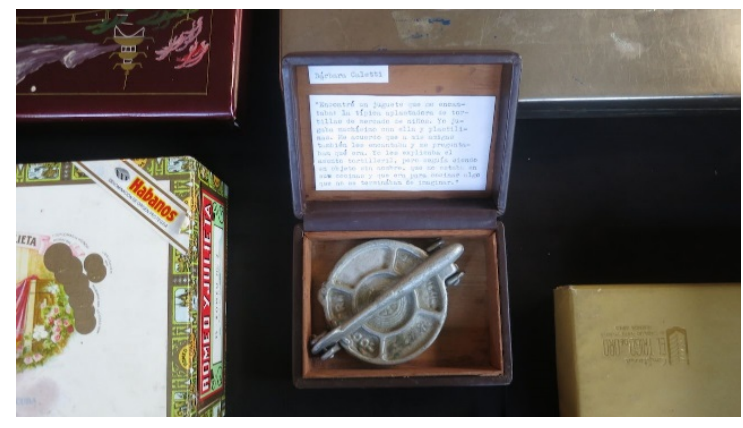

Imagen 139. "Encontré un juguete que me encantaba: la típica aplastadora de tortillas de mercado de niños. Yo jugaba muchísimo con ella y plastilinas. Me acuerdo que a mis amigas también les encantaba y me preguntaban qué era. Yo les explicaba el asunto tortilleril, pero seguía siendo un objeto sin nombre, que no estaba en sus cocinas y que era para cocinar algo que no se terminaban de imaginar...", Bárbara Caletti. (Extraído de la página web de Joselevich Puiggrós).

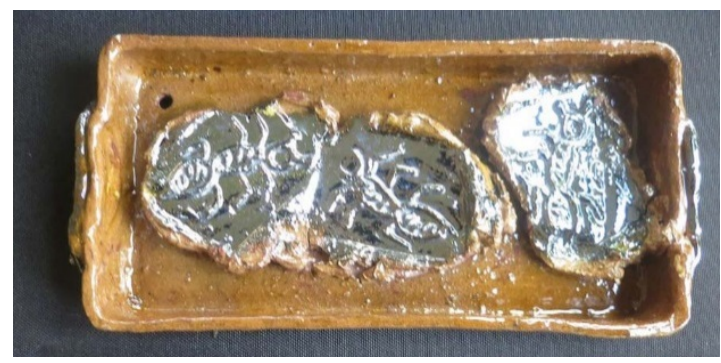

Imagen 140. "Para Pablo Sessano lo mejor que se trajo del exilio fue el arte cerámico." (Extraído de la página web de Joselevich Puiggrós).

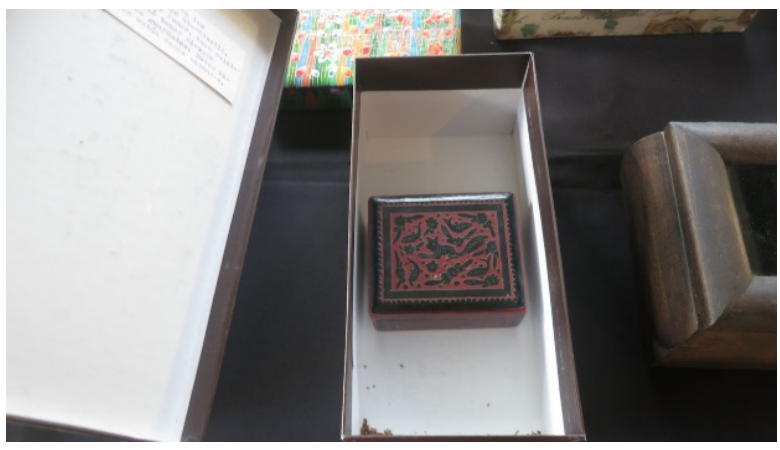

Imagen 141. "Caja donde guardaba los cigarrillos Mempo Giardinelli. Cuando dejó de fumar, hace 20 años, decidió tener siempre cigarrillos en casa. Dentro de la caja aún están esos cigarrillos." (Extraído de la página web de Joselevich Puiggrós).

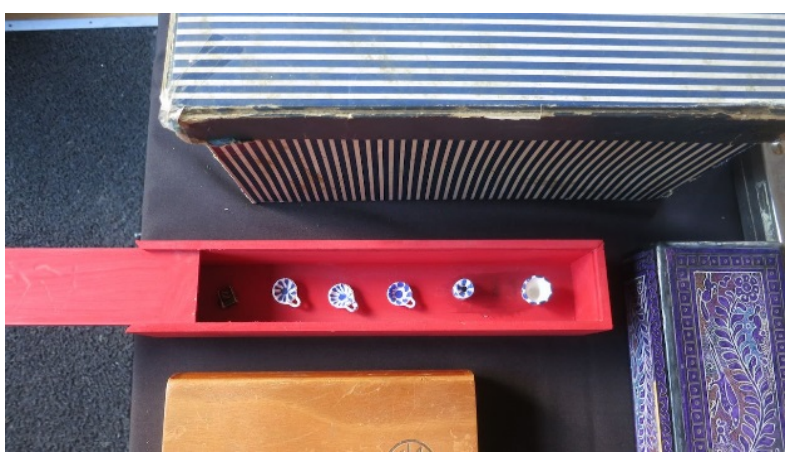

Imagen 142. Adornos cerámicos mexicanos.

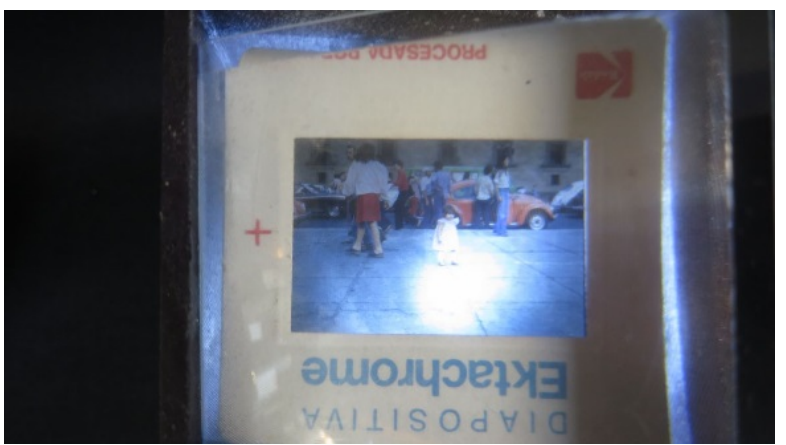

Imagen 143. Diapositiva con fotografía en el exilio. 


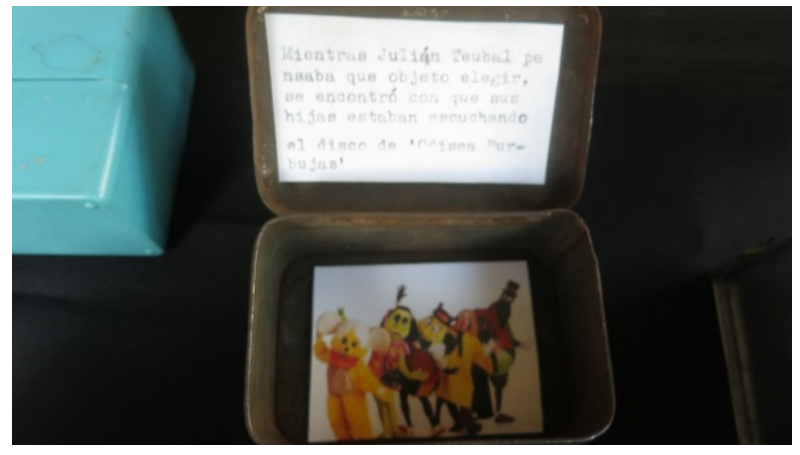

Imagen 144. "Mientras Julián Teubal pensaba qué objeto elegir, se encontró con que sus hijas estaban escuchando el disco de "Odisea Burbujas"”. (Extraído de la página web de Joselevich Puiggrós).

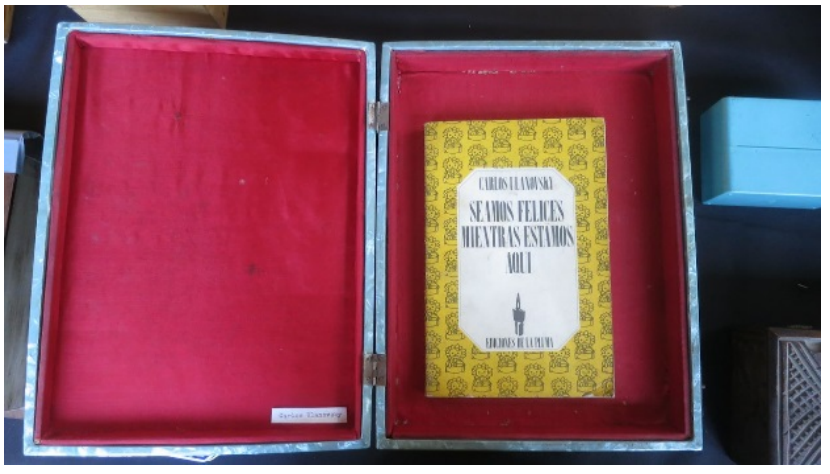

Imagen 145. "Libro aportado por Carlos Ulanovsky". (Extraído de la página web de Joselevich Puiggrós). 


\section{FUENTES}

\section{Páginas web de los artistas}

Casullo, Liza: www.lizacasullo.com

Fidanza, Mercedes: www.mercedesfidanza.com

Jitrik, Magdalena: www.orquestarojasepresenta.blogspot.com.ar

Videos en vimeo: www.vimeo.com/user4115891

Joselevich Puiggrós, Federico: www.ludic.cc

Sánchez Goldar, Soledad: www.sanchezgoldar.blogspot.com.ar

www.sites.google.com/site/soledadsanchezgoldar

Ulanovsky, Inés: www.inesulanovsky.com

\section{Otros sitios consultados}

Cámara Oscura: www.camaraoscura.com.ar/portfolio.php?id_portfolio=20

H.I.J.O.S.: www.hijos-capital.org.ar

Indymedia, Centro de medios independientes: www.argentina.indymedia.org

Grupo público de Facebook "Hijas e Hijos del Exilio:

www.facebook.com/groups/139965236014787/?fref=ts

Mesa de Escrache Popular: http://mesadeescrache.blogspot.com.ar

Pazquinsur Publicación Cultural:

www.pazquinsur.blogspot.com.ar/2011/11/tres-bellas-heridas-perfomance-

de.html

Revista de Artes Visuales Ramona: www.ramona.org.ar

\section{Entrevistas propias realizadas para esta investigación}

Alzogaray, Tomás, lunes 8 de junio de 2015.

García Canclini, Néstor, martes 31 de febrero de 2012.

Jaramillo, Ana, miércoles 22 de agosto de 2012.

Jitrik, Magdalena, lunes 15 de junio de 2015.

Joselevich Puiggrós, Federico, s/f. 
Ulanovsky, Inés, viernes 21 de febrero de 2014.

\section{Otras entrevistas}

Fidanza Mercedes, 09/05/2015, Recuperado de:

www.mixcloud.com/cosmopolisradio/entrevista-con-mercedes-fidanza-artista-visual

\section{Audiovisuales}

Ulanovsky Inés (1997). Pasaportes.

Burkart Noe Violeta y Miller Analía (2007). Argenmex, exiliados hijos.

\section{Libros de artistas y otras publicaciones}

Bufano, S. (comp.) (2009). Controversia: para el examen de la realidad argentina. Buenos Aires: Ejercitar la Memoria

Brodsky. M. (2001). Nexo. Un ensayo fotográfico de Marcelo Brodsky. Buenos Aires: La marca editora.

Ulanovsky, I. (2006). Fotos tuyas. Buenos Aires: Secretaría de Cultura de la Nación.

\section{BIBLIOGRAFÍA}

Plataforma Argentina contra la impunidad. (2006). Carta abierta de las Hijas e Hijos de exiliados. Recuperado de:

www.plataforma-argentina.org/spip.php?article339

Agamben, G. (2002). Lo que queda de Auschwitz. El archivo y el testigo. Homo Sacer III. Barcelona: Pre-textos.

Alonso, L. (2011). Capítulo V. H.I.J.O.S. y la reinvención del movimiento. En Luchas en plazas vacías de sueños. Movimiento de derechos humanos, orden local y acción antisistémica en Santa Fe (pp. 183-228). Rosario: Prohistoria Ediciones.

Amado, A. (2009). La imagen justa. Cine argentino y política (1980-2007). Buenos Aires: Colihue. 
Amado, A., y Domínguez, N. (comps.). (2004). Lazos de familia. Herencias, cuerpos, ficciones. Buenos Aires: Paidós.

Amar Sánchez, A. M., y Basile, T. (eds.). (2014). Derrota, melancolía y desarme. Los años '90 en la narrativa latinoamericana. Número Especial de la Revista Iberoamericana del Instituto Internacional de Literatura Iberoamericana, 80(247), 327-349.

Antón, G., Cresto, J., Rebón, J., y Salgado, R. (2010). Una década en disputa. Apuntes sobre las luchas sociales en la Argentina. Revista OSAL, CLACSO, Buenos Aires, 11(28), 95-116.

Arellano, M. P., y Fidanza, M. (2012). Taller fronteras Migrantes: una experiencia artística-social. En: Arte y memoria. Miradas sobre el pasado reciente. $V$ Seminario Internacional políticas de la Memoria, Buenos Aires: Centro Cultural de la Memoria Haroldo Conti,

Arfuch, L. (2007). Álbum de familia. En Crítica cultural entre política y poética (pp. 41-56). Buenos Aires: Fondo de Cultura Económica.

(2007). Memoria y autobiografía. En Crítica cultural entre política y poética (pp. 159-175). Buenos Aires: Fondo de Cultura Económica - (2005). Problemas de la identidad. En L. Arfuch. (comp.), Identidades, sujetos y subjetividades (pp. 21-43). Buenos Aires: Prometeo.

Aruj, R. y González, E. (2008). El retorno de los hijos del exilio. Una nueva comunidad de inmigrantes. Buenos Aires: Prometeo.

Barilari, L. (2011). Soledad Sánchez Goldar: Artista IN. Cualquiera. Recuperado de: http://cualquieraenradio.blogspot.com.ar/2011/03/soledad-sanchez-goldarartista-in.html

Barthes, R. (2012). La cámara lúcida. Nota sobre la fotografía. Buenos Aires: Paidós.

Basso, F. (2015). Indisciplinar las artes: memoria e imagen. En A. C. Arias y M. D. López (comps.). Indisciplinas. Reflexiones sobre prácticas metodológicas en Ciencias Sociales. Diálogos entre investigadores/as en formación de la UNLP. La Plata: IICom y Club Hem (en prensa).

Baudrillard, J. (2010). El sistema de los objetos. México: Siglo veintuno editores. 
Belting, H. (2012). Antropología de la imagen. Buenos Aires: Katz Editores.

Benedetti, M. (1983). El “desexilio". El País. Recuperado de: http://elpais.com/diario/1983/04/18/opinion/419464807_850215.html

Bernetti, J., y Giardinelli, M. (2003). México: el exilio que hemos vivido. Memoria del exilio argentino en México durante la dictadura 1976-1983. Buenos Aires: Universidad Nacional de Quilmes Editorial.

Blejmar, J. (2008). Anacronismos. El río sin orillas. Revista de filosofía, cultura y política, (2), 200-211. Recuperado de: http://myegoo.s3.amazonaws.com/egoo/e1149008035/myegoo_rriijordanablejm ar_o.pdf

Blejmar, J., Fortuny, N., y García, L. I. (Eds.). (2013). Instantáneas de la memoria. Fotografía y dictadura en Argentina y América Latina. Buenos Aires: Libraria.

Brea, J. L. (2005). Estudios visuales. La epistemología de la visualidad en la era de la globalización. Madrid: Akal.

Bugnone, A. (2014). Algunos conceptos para pensar la política y lo político en el arte. I Jornadas de Estudios Políticos Latinoamericanos, 5 al 6 de junio de 2014, La Plata, Argentina. En Memoria Académica. FaHCE, UNLP. Recuperado de:

http://www.memoria.fahce.unlp.edu.ar/trab_eventos/ev.3935/ev.3935.pdf

Burkart Noe V., y Miller A. (2007). Argenmex, exiliados hijos (Tesina de Licenciatura), Universidad de Buenos Aires.

Checa, F. (2010). La idea de imagen artística en Aby Warburg: el Atlas Mnemosyne (1924-1929). En A. Warburg. Atlas Mnemosyne (pp. 135-154). España: Ed. Akal.

Ciancio, M. B. (2013). Sobre el concepto de posmemoria. En Congreso Internacional ¿Las víctimas como precio necesario? Memoria, justicia y reconciliación, Instituto de Filosofía, Centro de Ciencias Humanas y Sociales, Madrid. Recuperado de:

http://www.proyectos.cchs.csic.es/fdh/sites/default/files/2-2\%20Ciancio.pdf

Colectivo Situaciones. (2002). Situaciones $5(+1)$. Genocida en el barrio. Buenos Aires: Ediciones De Mano en mano. 
Cueto Rúa, S. (2008). Nacimos en su lucha, viven en la nuestra. Identidad, justicia y memoria en la agrupación HIJOS-La Plata (Tesis de Maestría). Universidad Nacional de La Plata. Facultad de Humanidades y Ciencias de la Educación. Recuperado de:

http://www.memoria.fahce.unlp.edu.ar/tesis/te.426/te.426.pdf

Da Silva Catela, L. (2002). No habrá más flores en la tumba del pasado. La experiencia de reconstrucción del mundo de los familiares de desaparecidos. La Plata: Ediciones Al Margen.

- (2009). Lo invisible revelado. El uso de fotografías como (re) presentación de la desaparición de personas en la Argentina. En C. Feld y J. Stites Mor (comps.). El pasado que miramos, Memoria e imagen ante la historia reciente (pp. 337-361). Buenos Aires: Paidós.

Da Silva Catela, L., Giordano, M., y Jelin, E. (Eds.). (2010). Fotografía e indentidad. Captura por la cámara devolución por la memoria. Buenos Aires: Nueva Trilce.

De Rueda, M. A. (2011). Imágenes, cuerpos políticos y memoria. En F. Soulages y S. Solas (comps.). Ausencia y Presencia Fotografia y cuerpos políticos (pp. 169179). La Plata: Edulp.

Didi-Huberman, G. (2004). Imágenes pese a todo. Memoria visual del Holocausto. Barcelona: Paidós.

- (2011). Ante el tiempo. Historia del arte y anacronismo de las imágenes. Buenos Aires: Adriana Hidalgo.

(2011). La lección de Warburg es que no existe saber sin sufrimiento. Carta. Revista de pensamiento y debate del Museo Nacional Centro de Arte Reina Sofia, (2), 30-33. Recuperado de:

https://issuu.com/museoreinasofia/docs/carta_n_2_completo/45

Ediciones.

Dornier-Agbodjan, S. (2004). Fotografias de familia para hablar de la memoria. Historia, Antropología y Fuentes Orales, Entre fábula y memoria, Barcelona, (32), 123-132. 
Dubois, P. (2008). El acto fotográfico y otros ensayos. Buenos Aires: La Marca Editora.

Durán, V. (2008) Representaciones de la ausencia. Memoria e identidad en las artes visuales. En L. Arfuch, y G. Catanzaro (comps.) Pretérito imperfecto. Lecturas críticas del acontecer (pp. 129-143). Buenos Aires: Prometeo Libros.

-- (2013) Imágenes íntimas, heridas públicas. En J. Blejmar, N. Fortuny, y L.I. García (Eds.). Instantáneas de la memoria. Fotografía y dictadura en Argentina y América Latina (pp. 157-172). Buenos Aires: Libraria.

Dutrénit Bielous, S. (2013). Dictadura y exilio en la narrativa de los hijos. Historia, Voces y Memoria. Revista del Programa de Historia Oral, Facultad de filosofía y Letras, Universidad de Buenos Aires, (5), 75-100.

Eliade, M. (1974). Tratado de historia de las religiones II. Madrid: Ediciones Cristiandad

Expósito, M., Vidal A. y Vindel J. (2013) Activismo artístico. En AAVV Perder la forma humana. Una imagen sísmica de los años ochenta en América Latina. (pp. 43-50). Madrid: Museo Nacional Centro de Arte Reina Sofía.

Falcón, A. (2014). El lugar de la "segunda generación" en la investigación sobre el exilio político. Notas en torno al documental Argenmex, exiliados hijos. Aletheia Revista de la Maestría en Historia y Memoria de la FaHCE, 5(9). Recuperado de:

http://www.aletheia.fahce.unlp.edu.ar/numeros/numero-9/arte-cult-mem/ellugar-de-la-201csegunda-generacion201d-en-la-investigacion-sobre-exiliopolitico.-notas-en-torno-al-documental-argenmex-exiliados-hijos

Feld, C., y Stites Mor, J. (comps.). (2009). El pasado que miramos, Memoria e imagen ante la historia reciente. Buenos Aires: Paidós.

Fidanza, M. (2013). Migraciones situadas: de cómo las formas de transitar el territorio desde el arte y la educación confluye en una investigación a partir de la Obra Artística colectiva "El Árbol del Desexilio" a la construcción del dispositivo "Fronteras Migrantes". En Coloquio de Investigación. Producción artística y Políticas públicas en América Latina, Departamento de Artes Visuales Prilidiano Pueyrredón y Casa Patria Grande Presidente Néstor 
Kirchner, Secretaría General de la Presidencia de la Nación, Buenos Aires. Recuperado de:

http://issuu.com/accionvisual/docs/2013-av-iuna-artes-visuales-producc

Fidanza, M., Arellano, P. M., Burkart, V., ... y Casademunt, N. (2012). Nuevos discursos colectivos sobre el exilio: Producciones artístico-políticas de la agrupación 'Hijas e Hijos del Exilio'. En I Jornadas de Trabajo sobre Exilios Políticos del Cono Sur en el siglo XX, La Plata. Recuperado de:

http://www.memoria.fahce.unlp.edu.ar/trab_eventos/ev.2525/ev.2525.pdf

Fortuny, N. (2008). La foto que le falta al álbum. Memoria familiar, desaparición y reconstrucción fotográfica en la obra de dos artistas argentinos. En XII Jornadas Nacionales de Investigadores en Comunicación, Rosario.

(2014). Memorias fotográficas. Imagen y dictadura en la fotografía argentina contemporánea. Buenos Aires: La Luminosa.

Franco, M. (2008). El exilio: argentinos en Francia durante la dictadura. Buenos Aires: Siglo XXI Editores.

Friedländer, S. (ed.) (2007). En torno a los límites de la representación. El nazismo y la solución final. Bernal: Universidad Nacional de Quilmes.

Garbatzky, I. (2013). Los ochenta recienvivos. Poesía y performance en el Río de la Plata. Rosario: Beatriz Viterbo Editora.

García Canclini, N. (1992). Culturas híbridas. Estrategias para entrar y salir de la modernidad. Buenos Aires: Editorial Sudamericana.

(1998). Argentinos en México: una visión antropológica. En P. Yankelevich (coord.). En México, entre exilios: una experiencia de sudamericanos (pp. 55-73). México: Plaza y Valdés.

García, L.I. (2011). Políticas de la memoria y de la imagen. Ensayos sobre una actualidad político-cultural. Chile: Facultad de Artes, Universidad de Chile.

García, L. I., y Longoni, A. (2013). Imágenes invisibles. Acerca de las fotos de los desaparecidos. En J. Blejmar, N. Fortuny y L.I. García. (Eds.). Instantáneas de la memoria. Fotografía y dictadura en Argentina y América Latina (pp. 25-44). Buenos Aires: Libraria. 
Gatti, G. (2011). Identidades desaparecidas. Peleas por el sentido de los mundos de la desaparición forzada. Buenos Aires: Prometeo Libros.

Giunta, A. (2009). Poscrisis: Arte argentino después de 2001. Buenos Aires: Siglo Veintiuno Editores.

Granieri, K., y Katz C. (Eds.). (2010). Taller Popular de Serigrafía (2002-2007). Alemania: Frankfurter Kunstverein.

Guattari, F., y Rolnik, S. (2013). Micropolítica. Cartografías del deseo. Buenos Aires: Tinta Limón.

Guber, R. (2001). La etnografía. Método, campo y reflexividad. Buenos Aires: Norma.

Halbwachs, M. (2011). La memoria colectiva. Buenos Aires: Miño y Dávila editores.

Hirsch, M. (1996). Past Lives: Postmemories in Exile. Poetics Today Exile and Creativity, 17(4), 659-686. Durham: Duke University Press.

---------- (2008). The Generation of Postmemory. En Poetics Today, 29(1), 103128. Durham: University Duke Press.

(2012). The generation of postmemory. Writing and visual culture after the Holocaust. New York: Columbia Universiti Press.

Huyssen, A. (2007). En busca del futuro perdido: cultura y memoria en tiempo de globalización, Buenos Aires: Fondo de Cultura Económica.

Jelin, E. (2012). Los trabajos de la memoria. Buenos Aires: Siglo XXI.

Jensen, S. (2008). ¿Por qué sigue siendo políticamente incorrecto hablar de exilio? La dificultosa inscripción del exilio en las memorias del pasado reciente argentino (1983-2007). Páginas. Revista Digital de la Escuela de Historia, Rosario, 1(1), 131-148.

-- (2011). Exilio e historia reciente. Avances y perspectivas de un campo en construcción. Aletheia Revista de la Maestría en Historia y Memoria de la FaHCE, 1(2). Recuperado de:

http://www.aletheia.fahce.unlp.edu.ar/numeros/numero-2/exilio-e-historiareciente--avances-y-perspectivas-de-un-campo-en-construccion

Jitrik, M. (2002). El fenómeno TPS. Roulotte, (6), 86-105. Recuperado de: http://www.roulottemagazine.com/demo/wp-content/uploads/TPS.-Roulotte061.pdf 
Krauss, R. (2002). Lo fotográfico. Por una teoría de los desplazamientos. Barcelona: Editorial Gustavo Gili.

Lara, L. (2009). Boris Cyrulnik. Vencer el trauma por el arte [entrevista a Boris Cyrulnik]. Cuadernos de pedagogía, España, (393), 42-47.

Lastra, S. (2014). Reseña de la actividad: Homenaje a México por su amistad y solidaridad con los académicos e intelectuales exiliados. 27 de noviembre de 2013, Biblioteca Nacional, Ciudad de Buenos Aires. Aletheia Revista de la Maestría en Historia y Memoria de la FaHCE, 4(8). Recuperado de:

http://www.aletheia.fahce.unlp.edu.ar/numeros/numeros/numero8/resenas/resena-de-actividad-homenaje-a-mexico-por-su-amistad-ysolidaridad-con-los-academicos-e-intelectuales-exiliados.-27-de-noviembre-de2013-biblioteca-nacional-ciudad-de-buenos-aires

(2014). Los retornos del exilio en Argentina y Uruguay: Una historia comparada de las políticas y tensiones en la recepción y asistencia en las posdictaduras (1983-1989) (Tesis de Doctorado). Universidad Nacional de La Plata. Facultad de Humanidades y Ciencias de la Educación. Recuperado de: http://www.memoria.fahce.unlp.edu.ar/tesis/te.1002/te.1002.pdf

- (2013) ¿Volver al hogar? La experiencia del retorno de los exiliados argentinos. Andamios. Revista de investigación Social, Universidad Autónoma de la Ciudad de México, 10(21), 321-344. Recuperado de:

http://www.redalyc.org/pdf/628/62828836015.pdf

LaCapra, D. (2008). Representar el Holocausto. Historia, teoría, trauma. Buenos Aires: Prometeo.

Levi, P. (2011). Si esto es un hombre. España: Océano.

-------- (2011). Los hundidos y los salvados. España: Océano.

Logie I. y Willem B. (2015). Narrativas de las postmemoria en Argentina y Chile: la casa revisitada. Alter/nativas Latin American Cultural Studies Journal, The Ohio State University, (5), 1-25. Recuperado de: https://biblio.ugent.be/publication/5638150/file/7126028.pdf 
Longoni, A. (2013). Prólogo. En J. Blejmar, N. Fortuny y L.I. García. (Eds.). Instantáneas de la memoria. Fotografía y dictadura en Argentina y América Latina (pp. 7-21). Buenos Aires: Libraria.

- (2010). Arte y Política. Políticas visuales del movimiento de derechos humanos desde la última dictadura: fotos, siluetas y escraches. Aletheia Revista de la Maestría en Historia y Memoria de la FaHCE, 1(1). Recuperado de: http://www.aletheia.fahce.unlp.edu.ar/numeros/numero-1/ana-longoni.-arte-ypolitica.-politicas-visuales-del-movimiento-de-derechos-humanos-desde-laultima-dictadura-fotos-siluetas-y-escraches (2007) Encrucijadas del arte activista en la Argentina. Ramona, revista de artes visuales, (74), (31-43). Recuperado de:

http://70.32.114.117/gsdl/collect/revista/index/assoc/HASH01de/101f5faa.dir/r 74 11nota.pdf

Longoni A. y Bruzzone G. (comps.). (2008). El Siluetazo. Buenos Aires: Adriana Hidalgo Editora.

Longoni A. y Mestman M. (2013). Del Di Tella a "Tucumán Arde”: vanguardia artística y politica en el 68 argentino. Buenos Aires: Eudeba

Lvovich, D. (2007). Historia reciente de pasados traumáticos. De los fascismos y colaboracionismos europeos a la historia de la última dictadura argentina. En M. Franco y F. Levín (comps.). Historia Reciente. Perspectivas y desafios para un campo en construcción (pp. 97-124). Buenos Aires: Paidós.

Meyer E. y Salgado E. (2002). Un refugio en la memoria. La experiencia de los exilios latinoamericanos en México. México: Océano.

Mirzoeff, N. (2003). Una introducción a la cultura visual. Barcelona: Paidós.

Muñoz Cobeñas, L. (2012). Las antígonas y el Estado. Aflicción y resistencia en el relato de mujeres. Buenos Aires: Biblos.

Nora, P. (dir.). (2008). Pierre Nora en les lieux de mémoire. Montevideo: Trilce.

Oberti, A. (2009). Lo que queda de la violencia política. A propósito de archivos y testimonios. Temáticas, 17(33/34), 125-148.

Oliveira-Cézar, M. (2004). El exilio argentino en Francia. Amérique Latine Histoire et Mémoire. Les Cahiers (1). Recuperado de: 
http://alhim.revues.org/67

Peller, M. (2012). Experiencias de la herencia. La militancia armada de los setenta en las voces de la generación de las hijas y los hijos. Revista Afuera (12). Recuperado de:

http://www.revistaafuera.com/articulo.php?id=237\&nro=12

Pereyra, S., Vommaro G., y Pérez G. (Eds.). (2013). La grieta: Política, economías y cultura después de 2001. Buenos Aires: Editorial Biblos.

Pérez Balbi, M. (2013) Hacer visible, hacer audible. El escrache de HIJOS y la PAH (un poco) más allá del activismo artístico (Trabajo final) Master en Estudios Museísticos y Teoría Crítica, Universidad Autónoma de Barcelona.

----------------- (2012). Entre internet y la calle: activismo artístico en La Plata.

Versión Estudios de Comunicación y Política, (30). Recuperado de:

http://version.xoc.uam.mx/

Pérez Rocca, J. P. (2008). El árbol del desexilio: reparación de las identidades. Ramona. Revista de artes visuales (78) Recuperado de:

http://70.32.114.117/gsdl/collect/revista/revistas/ramona78.pdf

Piccato Rodríguez, A. O. (2007). Cuando la infancia juega al exilio. En F. Serrano Migallón (coord.). El exilio argentino en México a treinta años del golpe militar, (pp. 41-47). México: Editorial Porrúa.

Pollak, M. (2006). Memoria, olvido, silencio. La producción social de identidades frente a situaciones límite. La Plata: Ediciones Al Margen.

Prividera, N. (2009). Plan de evasión. Recuperado de:

http://haciaelbicentenario.blogspot.com.ar/2009/05/plan-de-evasion.html

Ricœur, P. (2004). Fase documental: la memoria archivada. En La memoria, la historia, el olvido. Buenos Aires: Fondo de Cultura Económica.

Rolnik, S. (2008). Furor de archivo. Revista Colombiana de Filosofia de la Ciencia, 9(18-19), 9-22. Recuperado de:

http://www.redalyc.org/pdf/414/41411852001.pdf

Sarlo, B. (2012). Tiempo pasado: cultura de la memoria y giro subjetivo. Una discusión. Buenos Aires: Siglo XXI editores.

Shaeffer, J. M. (1990). La imagen precaria. España: Cátedra. 
Schechner, R. (2000). Performance. Teoría y prácticas interculturales. Buenos Aires: Libros del Rojas (UBA).

Serrano Migallón, F. (2002). “...duras tierras lejanas...” Un asilo, tres exilios. México: Fondo de cultura económica.

------------ (coord.). (2007). El exilio argentino en México a treinta años del golpe militar. México: Editorial Porrúa.

Sontag, S. (2012). Sobre la fotografía. Buenos Aires: Delbolsillo.

Sosensky, S. (2008). Los niños del exilio. Por una historia de la infancia exiliada en México. Destiempos, 3(13). Recuperado de:

http://www.destiempos.com/n13/susanasosenski_13.htm

Soulages, F. (2010). Estética de la fotografia. Buenos Aires: La marca editora

Spiegelman, A. (2011). Maus I. Historia de un sobreviviente. Mi padre sangra historia. Buenos Aires: Emecé.

-------------- (2011). Maus II. Historia de un sobreviviente. Y aquí comenzaron mis problemas. Buenos Aires: Emecé.

Svampa, M. (2013). Tras las lecturas y las huellas de diciembre de 2001. En S. Pereyra, G. Vommaro, y G. Pérez (Eds.). La grieta: Política, economías y cultura después de 2001 (pp. 21-32). Buenos Aires: Editorial Biblos.

Szurmuk, M. (2009). Posmemoria. En M. Szurmuk y R. Irgwin (Coord.). Diccionario de estudios culturales latinoamericanos (pp. 224-228). México: S. XXI Editores.

Taylor, D. (2012). Performance. Buenos Aires: Asunto Impreso Ediciones. (2000). El espectáculo de la memoria: trauma, performance y política. Teatro al Sur, (15), 34-40. Recuperado de: http://performancelogia.blogspot.com.ar/2007/08/el-espectculo-de-la-memoriatrauma.html

Todorov, T. (2008). Los abusos de la memoria. Barcelona: Paidós.

Traverso, E. (2001). La Historia desgarrada. Ensayo sobre Auschwitz y los intelectuales. Barcelona: Herder. 
(2007). Historia y Memoria: Notas sobre un debate. En M. Franco y F.

Levín (comps.). Historia Reciente. Perspectivas y desafios para un campo en construcción (pp. 67-96). Buenos Aires: Paidós.

Ulanovsky, C. (2011). Seamos felices mientras estamos aquí. Crónicas del exilio. Buenos Aires: Delbolsillo

Ulanovsky, I. (2010). Algunas madres también se mueren. Buenos Aires: Capital Intelectual.

Verzero, L. (2009). Estrategias para crear el mundo: la década del 70 en el cine documental de los dos mil. En: C. Feld y J. Stites Mor (comps.). El pasado que miramos, Memoria e imagen ante la historia reciente (pp. 181-217). Buenos Aires: Paidós.

Yankelevich, P. (Coord.). (1998). En México, entre exilios. Una experiencia de sudamericanos. México: Plaza y Valdés Editores.

--------------- (2002). México, país refugio. La experiencia de los exilios en el siglo $X X$. México: Plaza y Valdés.

(2009). Ráfagas de un exilio, Argentinos en México, 1974-1983. México: El colegio de México. 